
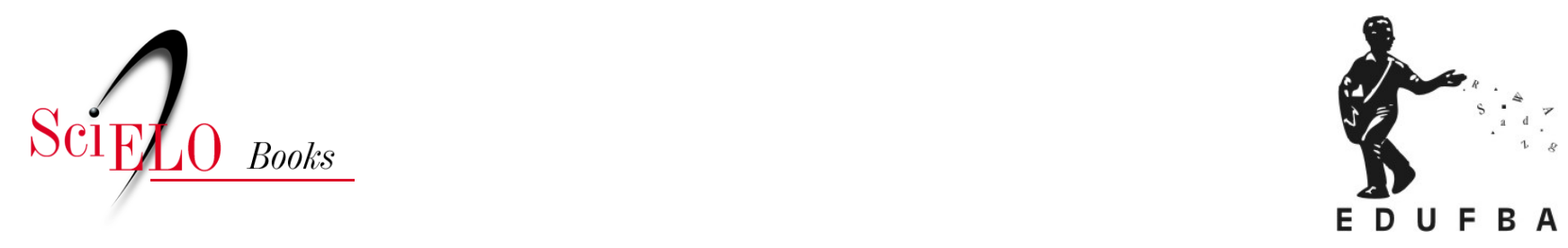

\title{
Produção social das políticas de saúde bucal no Brasil
}

\author{
Thais Regis Aranha Rossi
}

ROSSI, T.R.A. Produção social das políticas de saúde bucal no Brasil [online]. Salvador: EDUFBA, 2018, 222 p. ISBN 978-85-232-2022-8. https://doi.org/10.7476/9788523220228.

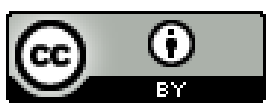

All the contents of this work, except where otherwise noted, is licensed under a Creative Commons Attribution 4.0 International license.

Todo o conteúdo deste trabalho, exceto quando houver ressalva, é publicado sob a licença Creative Commons Atribição 4.0. 


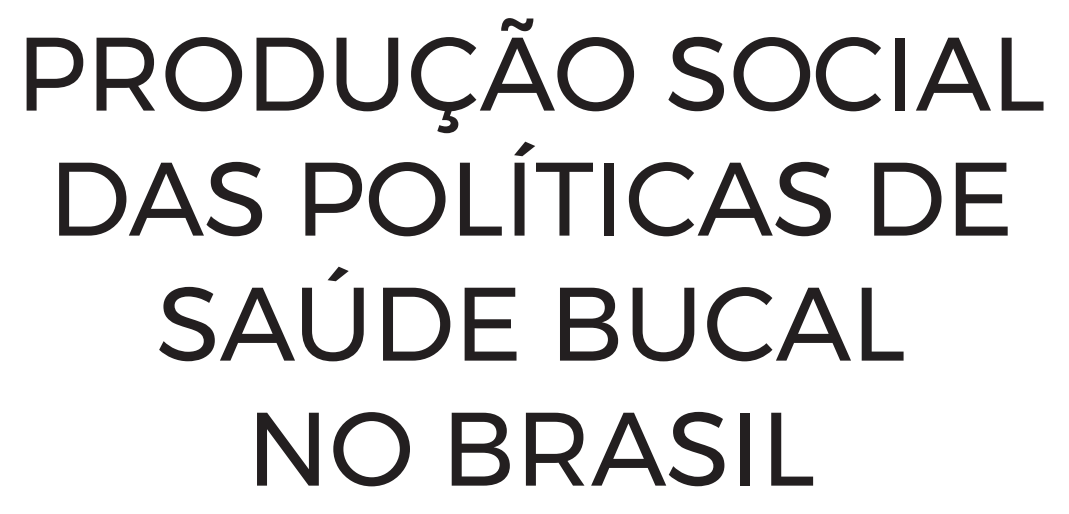




\section{UNIVERSIDADE FEDERAL DA BAHIA}

Reitor

João Carlos Salles Pires da Silva

Vice-reitor

Paulo Cesar Miguez de Oliveira

Assessor do Reitor

Paulo Costa Lima

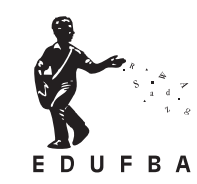

EDITORA DA UNIVERSIDADE FEDERAL DA BAHIA

Diretora

Flávia Goulart Mota Garcia Rosa

Conselho Editorial

Alberto Brum Novaes

Angelo Szaniecki Perret Serpa

Caiuby Alves da Costa

Charbel Ninõ El-Hani

Cleise Furtado Mendes

Evelina de Carvalho Sá Hoisel

José Teixeira Cavalcante Filho

Maria do Carmo Soares de Freitas

Maria Vidal de Negreiros Camargo

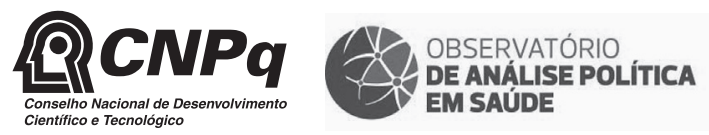


Thais Regis Aranha Rossi

\section{PRODUÇÃO SOCIAL DAS POLÍTICAS DE SAÚDE BUCAL NO BRASIL}


2018, Thais Regis Aranha Rossi.

Direitos dessa edição cedidos à Edufba.

Feito o Depósito Legal

Grafia atualizada conforme o Acordo Ortográfico da Língua Portuguesa de 1990, em vigor no Brasil desde 2009.

Capa, Projeto Gráfico e Diagramação

Rodrigo Oyarzábal Schlabitz

Revisão

Hilário Mariano dos Santos Zeferino

Normalização

Sandra Batista

Imagem da capa

Freepik.com

Sistema de Bibliotecas - UFBA

R831 Rossi, Thais Regis Aranha

Produção social das políticas de saúde bucal no

Brasil/Thais Regis Aranha Rossi. - Salvador: EDUFBA, 2018.

$223 \mathrm{p}$.

Inclui referências

ISBN 978-85-232-1751-8

1. Saúde bucal - Brasil. 2. Saúde pública - assistência. odontológica. 3. Política de saúde - saúde bucal. I. Título.

Editora afiliada à

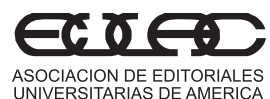

ASOCIACION DE EDITORIALES LATINA YEL CARIBE
LATITE

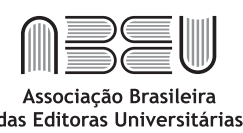

$\mathrm{CBaL}$

Câmara Bahiana do Livro

Editora da UFBA

Rua Barão de Jeremoabo, s/n - Campus de Ondina

40170-115 - Salvador - Bahia / Tel.: +55 71 3283-6164

www.edufba.ufba.br / edufba@ufba.br 
À minha família, ao meu esposo e ao meu filho, por todo apoio frente ao campo dos possíveis, a partir de uma origem popular. 
De fato, apenas uma verdadeira crônica construída poderia fazer sentir concretamente que esse universo aparentemente anárquico e de bom grado libertário - o que ele é também, graças aos mecanismos sociais que autorizam e favorecem a autonomia - é o lugar de uma espécie de balé bem ordenado, no qual os indivíduos e os grupos desenham suas figuras, sempre se opondo uns aos outros, ora se defrontando, ora caminhando no mesmo passo, depois dando-se as costas, em separações muitas vezes retumbantes, e assim por diante até hoje. (BOURDIEU, 1998, p. 133) 


\section{SUMÁRIO}

PREFÁCIO / 11

INTRODUÇÃO / 21

Metodologia utilizada para construção deste trabalho / 30

ANTECEDENTES E QUESTÕES EM DISPUTA RELATIVOS À

CONSTRUÇÃO DOS PROBLEMAS BUCAIS ATÉ 1989 / 45

Plano de reorientação da assistência odontológica (Praod) e ações do Inamps / 56

Políticas de Saúde Bucal no âmbito do Instituto de Pesquisas Econômicas Aplicadas (IPEA) / 62

CONDIÇÕES DE POSSIBILIDADE HISTÓRICAS PARA A EMERGÊNCIA DE POLÍTICAS DE SAÚDE BUCAL NO PÓS-CONSTITUINTE / 65

Papel do Instituto de Pesquisas Econômicas Aplicadas (IPEA) e Finsocial / 65 Luta pela democratização e a saúde / 66

Do GT - Odonto à Divisão Nacional de Saúde Bucal (DNSB) / 85

POLÍTICA NACIONAL DE SAÚDE BUCAL (PNSB) DE 1989 / 93

Regulamentação específica para fluoretação nos cremes dentais e enxaguatórios / 100

O espaço de formulação e crítica das políticas de saúde bucal / 101

MUDANÇAS NA TABELA SIA/SUS E PROCEDIMENTOS COLETIVOS / 11 
FLUORETAÇÃO DO SAL DE COZINHA E MOVIMENTO ANTI-FLÚOR / 123

Grupos e agentes que influenciaram no espaço de formulação da política / 143

Procedimentos coletivos no decorrer da década de 1990 / 152

INSERÇÃO DA SAÚDE BUCAL NO PROGRAMA SAÚDE DA FAMÍLIA / 155

Participantes e disposições que influenciaram a inclusão da equipe de saúde bucal no Programa de Saúde da Família / 171

POLÍTICA BRASIL SORRIDENTE / 179

Análise dos participantes e críticos do espaço de formulação das políticas de saúde bucal / 191

CONSIDERAÇÕES FINAIS / 199

POSFÁCIO / 205

REFERÊNCIAS / 207 


\section{PREFÁCIO}

Creio que, desde o tempo de Homero, para redigir um prefácio há um rito a ser cumprido: invoca-se a musa e se anuncia o assunto.

Pulo a primeira parte do rito. Anuncio logo, ao leitor, a propícia ocasião para o lançamento de uma obra com abordagem histórica e, ao mesmo tempo, com repercussões situacionais para o momento presente. Obra que resgata e ressignifica a construção da Política Nacional de Saúde Bucal (PNSB) no Brasil - com seus atores, autores, eventos e narrativas. Cumpre esclarecer também o papel cumprido por este paratexto editorial, pois, de fato, este é um prefácio "posterior" à publicação da obra "original". Explica-se: o livro foi fecundado e nasceu depois da defesa de uma tese de doutorado a qual tive o privilégio de acompanhar em suas etapas intermediárias e, depois, na defesa pública. Agora, como naquela ocasião, louvamos o mérito da eleição do tema e da abordagem metodológica escolhida pela então doutoranda.

Logo na página de rosto, cita-se Pierre Bourdieu, As regras da arte (1998). Reparem, leitores, estamos em solo baiano com atmosfera intelectual francesa, pois o lócus de produção da tese/livro é o Observatório de Análise de Política do Instituto de Saúde Coletiva da Universidade Federal da Bahia (ISC/UFBA) - com passagem pelo Centre Européen de Sociologie et de Science Politique (CESSP) de Paris. Kudos para a autora, que nos proporciona um ambiente tão inspirador, Bahia-França: axé, à votre santé! E dizia então Bourdieu:

De fato, apenas uma verdadeira crônica construída poderia fazer sentir concretamente que esse universo [...] é o lugar de uma espécie de balé bem ordenado, no qual os indivíduos e os grupos desenham suas figuras, sempre se opondo uns aos outros, ora se defrontando, ora caminhando no mesmo passo, depois dando-se as costas, em separações muitas vezes retumbantes, e assim por diante até hoje. 
Enfatizo esta abertura bourdieusiana - ela será muito pertinente adiante -, porque é preciso lembrar, também, que o prefácio, dentre muitas funções, pode ser uma forma lateral de "comentário" crítico, embora exija prudência na sua redação para não atravessar a tênue fronteira que pode derivar para o "ensaio" crítico - um formato textual que, salvo engano, seria desproporcional ou descabido aqui. Deixemos para apresentar um breve comentário crítico logo adiante, quando mencionarei, inclusive, a validade temporal desta obra. Antes disso, cumpre atender a mais uma função do prefácio, que é de reter o leitor por um processo tipicamente retórico de persuasão. Eu quero valorizar a cuidadosa redação do texto, sem indispor nosso leitor com uma indiscreta apresentação de "spoilers" - muito em voga na era digital -, antecipando trechos centrais do livro que façam revelações e prejudiquem ou arruínem a apreciação da leitura pela primeira vez pelo próprio leitor.

Pois, cumprindo esta função, posso afirmar que a obra não é tagarelice superficial, como muitos textos que foram produzidos e publicados na última década, aproveitando-se de um modismo temático utilitarista, que somente tentou surfar na onda do êxito político circunstancialmente obtido pela PNSB - em especial, na fase do "Brasil Sorridente". E aqui se impõe assinalar uma questão que assombra qualquer autor que, em menor ou maior grau, aspire produzir uma obra com componentes históricos em ambiente acadêmico: a "veracidade" da narrativa histórica e a eficácia heurística para apoiar a interpretação de distintas realidades. A exposição do método sempre pretende nos oferecer uma "garantia", através da reivindicação da consistência dos meios utilizados. Nesse sentido, o trabalho aqui produzido constitui uma potente lupa que aumenta substancialmente o campo e a profundidade de visão do leitor sobre uma história ainda inconclusa, da PNSB, conferindo ao livro uma atemporalidade, mas, ao mesmo tempo, uma atualidade e acoplamento conjuntural para apreender o momento presente. Esta virtude poderia se converter rapidamente em frustração, não fosse o talento da autora; os argumentos trabalhados no livro poderiam perder inexoravelmente sua validade fática e seu sentido de história viva, no transcurso de importantes mudanças no Brasil e na PNSB, a partir de 2015-2016. Gostaríamos, evidentemente, que todo o material tratado aqui fosse parte de um conjunto in progress, ou seja, com uma validade que encontraria sua plena significação no contexto futuro, em um Brasil com democracia madura e respeito republicano à Constituição e ao Sistema Único de Saúde (SUS) consolidado..., mas, aí, já caímos no imponderável.

O objetivo geral apresentado pela autora é analisar, por meio de abordagem sócio-histórica, a produção social da PNSB, de 1989 a 2004. No texto introdutório, ela sumariza uma ampla revisão em que perfilam publicações que têm se apoiado 
em descrições sobre o surgimento e desenvolvimento das políticas de saúde bucal, mas muitas dessas publicações frequentemente pecam pela forma bastante naturalizada ou espontânea de suas abordagens. São autores que escrevem como se estivessem endereçando a mensagem para uma torcida clubística, numa espécie de câmara de eco, uma "bolha" comunicacional, na cena da "pregação para fiéis convertidos”. É quase sempre o mesmo público: são autores, atores, personagens, protagonistas, agonistas, biógrafos em movimento circular - falando, agindo, escrevendo, fazendo a história de si mesmos. Talvez, se não parecesse surrealista demais, coubesse a advertência das telas de cinema: "[ao contrário das obras de ficção, nenhuma das] personagens e as situações desta narrativa são puramente fictícias e qualquer semelhança com pessoas ou situações existentes [não] é mera coincidência”. As razões profundas acerca da emergência processual da PNSB em conjunturas específicas, em um tempo mais dilatado, com a participação de agentes externos e, muitas vezes, hostis ao campo da saúde (bucal) coletiva, têm sido pouco investigadas.

Em um dos seus objetivos específicos, chama logo a atenção a proposição de analisar como os problemas de saúde bucal se tornaram problemas sociais no Brasil, de 1989 a 2004. A pergunta é: mas, se tornaram?

Conforme já foi apontado alhures, nota-se, por um lado, a ausência de movimentos populares com demandas por serviços odontológicos ou organizações de usuários (com dentes) cariados ou portadores de doenças periodontais ou na luta por próteses dentárias no processo de construção das políticas de saúde bucal. Por outro, a partir da própria definição citada pela autora, os problemas sociais são o produto de uma construção que compreende seu reconhecimento e sua legitimação como tal, sendo "instituídos em todos os instrumentos que participam da formação da visão corrente do mundo social”, que pode ser nos organismos e regulamentações que visam encontrar uma solução, ou mesmo nas "categorias de percepção e pensamento que lhe correspondem”. Assim, sua legitimação envolve uma operação para inseri-los nas preocupações sociais do momento.

A compreensão sobre o processo de produção social das políticas de saúde bucal no Brasil implica a análise do espaço de formulação dessas políticas, bem como dos agentes que participaram ou influenciaram na sua formulação. Segundo o referencial teórico utilizado, esses agentes podem ser situados em um lugar do espaço social definido pelas suas propriedades relativas, a saber: volume global de capital e sua composição (capital científico, burocrático e político, principalmente) e trajetória social. O espaço social também pode ser descrito como um campo de forças entre os agentes, na medida em que as propriedades consideradas para 
a sua constituição, como as diferentes espécies de poder ou capital são atuantes. Cada campo, como microcosmo social relativamente autônomo, possui suas leis específicas, seus objetos de disputas, seus habitus e interesses específicos - illusio. No presente caso, contando também com o aporte teórico de Pinell, utiliza-se o conceito de espaço social em que agentes de diversos campos interagem com habitus diferenciados, porém partilhando de um mesmo interesse na questão em jogo no espaço específico.

Não é tarefa a ser cumprida no prefácio oferecer ao leitor menos familiarizado com o referencial bourdieusiano um glossário de seus principais termos e conceitos. A autora fará isto com grande competência, no corpo do livro. Porém, cabe enfatizar brevemente aqui o conceito de illusio. Bourdieu deplorava o uso de seus conceitos para o propósito de grandes reflexões sociológicas que se aventurassem por uma teoria geral das sociedades; ao contrário, seus conceitos são "operacionais" - evitando a "audácia teórica sem rigor metodológico”. Operacionalmente, a illusio poderia ser entendida como

[...] dar importância a um jogo social, estar preso ao jogo, acreditar que o jogo vale a pena, perceber que o que se passa aí é importante para os envolvidos, é reconhecer o jogo e reconhecer os alvos; admitir, portanto, que o jogo merece ser jogado e que os alvos engendrados merecem ser perseguidos, em uma relação de cumplicidade entre as estruturas mentais dos agentes jogadores e as estruturas objetivas do espaço social. (BOURDIEU, 1996)

Não se devem esquecer as fissuras e as contradições entre objetos e apostas diferenciadas que integram todas as possíveis illusios coletivas, pois os atores podem manifestar "interesses" diversos sobre o mesmo objeto, o mesmo jogo social, com alianças temporárias e disputas contingentes a depender da situação e do interesse específico.

O presente estudo privilegiou, em sua análise, as respostas sociais formalizadas, ou seja, traduzidas em ações. A reconstrução de um processo de emergência histórica não se reduz a um puro e simples encadeamento de acasos; muito mais, ela implica a busca da elucidação crítica de uma lógica sócio-histórica específica. A estrutura dos campos que influenciaram/influenciam as políticas de saúde bucal foi estudada através da relação de forças entre os agentes ou instituições engajadas na luta, assim como na distribuição dos capitais específicos, acumulados em lutas pregressas e que, por sua vez, determinaram as estratégias de ação. A estratégia 
adotada por grupos, por agentes coletivos, é produto do senso prático quanto ao sentido do jogo ou um domínio empírico da lógica que se adquire pela experiência.

De especial relevância para o objeto do livro, situa-se o Estado como um metacampo com poder sobre os outros campos e que se superpõe ou mesmo corresponde ao campo burocrático. Nele, os agentes envolvidos, muitas vezes, pertencem a diversos outros campos, com distintos capitais acumulados, estabelecendo o jogo ora consensual, ora conflitivo, na construção do problema-objeto da política como um problema social.

A abordagem sócio-histórica é reivindicada como característica distintiva desta obra. Torna-se saliente, então, situar com precisão um aspecto de seu referencial teórico e empírico: a sociologia reflexiva e genética de Pierre Bourdieu. De grande relevo para demarcar esta investigação específica, é a propriedade com que se utiliza o conceito bourdieusiano de "amnésia de gênese" (Sobre o Estado, Cursos no College de France - 1989-1992). Bourdieu expõe a dificuldade e a necessidade de analisar o objeto de estudo "de fora", particularmente neste caso desde uma política pública de Estado (mas, sem perder contexto e historicidade); livre de opiniões já sedimentadas pelo senso comum (ou pelo habitus, no campo burocrático). É preciso se descolar de preconceitos, de conscientes e inconscientes pré-formatados. Nas suas próprias palavras:

O pesquisador totalmente desprovido de instrumentos de pensamento, que ignora os debates em curso, as discussões científicas, as contribuições, [...], arrisca-se, seja a ser ingênuo, seja a reinventar o já conhecido, mas, se ele conhece em demasia, arrisca-se a ficar prisioneiro de seu conhecimento.

No caso sob análise no livro, o esquecimento das origens tornaria aparentemente óbvio algo que não é óbvio, mas que sua mera existência “naturalizada” permitiria a sua institucionalização como algo dado. Por exemplo, como se a PNSB tivesse "aparecido" no espaço lacunar da história em um arroubo voluntarista de um ministro qualquer, cumprindo expediente no Ministério da Saúde, exercendo seu poder e acúmulo de capital burocrático. Em suma, a amnésia de gênese é tornar "natural" - sob a forma de doxa (ou crença ingênua) - o que antes não era visto como natural e não poderia ter sido natural, sob o olhar atento e historicamente rigoroso da socioanálise.

O desenvolvimento das políticas de saúde bucal no Brasil, no sentido da historiografia tradicional seria apenas uma evolução cronológica, em uma linha do tempo sequencial, com fatos e personagens desfilando em narrativa monótona. In- 
versamente, no sentido histórico da socioanálise aqui empreendida, o enredo nos "enreda" em complexidades crescentes, em elaborações intrincadas, em enigmas desafiadores postos pela esfinge da realidade social brasileira que nos devora. De tal modo, este desenvolvimento é sincrônico e diacrônico, ele decorreria de um longo processo de continuidades e rupturas resultante das proposições oriundas do espaço da Saúde Bucal Coletiva (SBC), que vai se constituindo em processos de lutas, em disputas internas com setores mais conservadores do "sanitarismo ou do preventivismo" tradicional de décadas passadas, bem como nas disputas externas (ou melhor, transversalmente) com a odontologia liberal e seus interesses de mercado. A análise desenvolvida auxilia na compreensão do complexo processo da formulação das políticas de saúde bucal, sendo possível apreender esta lógica de descontinuidades, de emergência de micropoderes, de política de bastidores, de acordos, de enfrentamentos, ou seja, as estruturas e a dinâmica do jogo social que nos daria melhores bases e ferramentas para interpretar e agir em cenários futuros.

Porém, com um toque de pessimismo, que pode bem vestir como uma luva no Brasil, desde 2015, e ser aplicado aos destinos do SUS e da PNSB em um horizonte próximo, Bourdieu adverte:

a amnésia da gênese [...] elimina os 'possíveis' (possíveis mundos, sociedades, tipos de Estado, soluções históricas) e nos faz esquecer que são possíveis, e que ela até mesmo torna impensáveis os possíveis. Há possíveis que são revogados de uma vez por todas, mais gravemente do que se fossem proibidos, pois os tornamos impensáveis.

Ou seja, todo nosso horizonte histórico se reduz à fórmula minimalista: "é assim por que é assim”! Poderíamos, para exemplificar, perguntar por que o Estado aparelhado pela juristrocracia se impôs desse modo no Brasil atual? Porque sim! Esta anulação de "possíveis", para Bourdieu, seria também uma forma de "golpe de Estado". Algo a se pensar...

Correríamos o risco de ver a obra aqui prefaciada restar como um "monumento" erigido como resgate/homenagem a um tempo passado, muito breve, de grandes esperanças e, simultaneamente, de imprevisíveis reviravoltas? Lembrando de Bourdieu, é preciso registrar o poder derrogatório do neoconservadorismo que "demarca seus territórios" a ferro e fogo - inclusive, hoje, no campo legislativo na pretensa "casa do povo", afirmando-o como campo de interesses privados, balcão de negócios para a mercantilização da saúde, anulando vorazmente as laboriosas conquistas obtidas pelo campo popular e democrático até 2015. 
É o momento, agora, de passarmos para o comentário crítico. O prefácio cumpre sua outra possível função, ou seja, de para-raios da obra, atraindo a atenção do leitor para as "descargas elétricas", neste caso, para as tensões políticas e embates sociais que animam a PNSB mais recentemente, em período histórico não coberto pelo livro. Isto será feito brevemente, desde os movimentos produzidos por uma comunidade de interessados, seus protagonistas internos, até alcançar uma audiência mais ampla. Aqui entraria a crítica paralela ao texto, uma outra construção, outras fontes... e, inevitavelmente, a "escolha" de um público.

Para a autora do livro, talvez por elegância de estilo, talvez por constrangimento ético de expor alguns de seus entrevistados, não foi possível desvelar intimamente algumas contradições centrais que habitam o campo da SBC e da PNSB. Acompanhando e conhecendo muitos dos agentes entrevistados, seus capitais acumulados, suas origens e trajetórias, posições ocupadas no espaço social e tomada de posição quanto à PNSB, eu posso sugerir pelo menos duas situações.

Uma delas, muito curiosa em suas posições no campo da SBC, profere uma certa "evocação" internalista da PNSB, quero dizer, comete o deslize fetichista de crítica feroz aos seus insuficientes avanços - fazendo com que a política fique subitamente autonomizada, descolada da realidade social maior em que ela se desenrola. Desse modo, a PNSB expressaria virtudes e defeitos como uma "potência" contida em si mesma, que se basta a si mesma. Para esses críticos, a expressão programática atual da PNSB - o Brasil Sorridente - seria o alfa e o ômega e sua condução histórica, bem como seus resultados práticos, somente uma decorrência de maior ou menor "competência gerencial". O que faltaria então à PNSB - e ao SUS de maneira geral - seria um modelo de gestão eficiente! Mas, e o contexto? E as condições objetivas externas, da política e sociedade mais geral, que atravessam internamente a PNSB?

Outra visão oposta, mas igualmente reducionista e falsa - porque é hagiográfica -, produz uma idealização da PNSB como a expressão particular de sucesso absoluto de um "grande programa" político externo, totalizante. Nessa visão, busca-se destacar a biografia de alguns "santos" da Reforma Sanitária Brasileira e da SBC, invocados permanentemente como operadores dos milagres da existência do SUS e de seus correlatos tais como a PNSB.

A noção de "campo" é útil para evitar ambas visões reducionistas - a internalista-autonomista, de partenogênese e refração total ao ambiente externo; e a visão externalista-estruturalista, que comete o erro de "curto-circuito" ao raciocinar como se o campo funcionasse somente mediante a determinação de leis sociais 
gerais da formação social, sendo bem interpretadas e acionadas por "iluminados", sem mediações, sublimações e lutas internas de seus agentes.

Esse mundo dos sujeitos com certezas absolutas lhes produz cegueiras situacionais (ou enquadramentos cognitivos limitados). Ocorre que, de pequenas ou grandes arapucas e infidelidades, assim vão se esfacelando as relações outrora orgânicas que permitiram construções coletivas como a PNSB (diferenças sempre existiram no interior desse coletivo, mas havia um limite, uma fronteira de respeitabilidade mútua que não deveria ser ultrapassada). Quando a PNSB começou a sofrer de "fogo amigo", uma história respeitável, que é o desdobramento da reforma sanitária no espaço da saúde bucal coletiva, começou a ser depreciada, rebaixando simultaneamente uma parte da história do SUS. Isto nos mostra muito mais que brigas intestinas, entre agentes da SBC e suas idiossincrasias. Porque, de fato, algo maior já estava se perdendo, paralelamente aos eventos mais recentes de destituição de coordenadores nacionais de saúde bucal no Ministério da Saúde (episódios ocorridos a partir de 2015). Um novo rumo já estava sendo dado para a imatura democracia brasileira e, nesse contexto, a história foi implacável.

Na contramão de tudo que lutamos e conseguimos construir, no árduo processo de redemocratização do Brasil e de construção social de políticas públicas mais equânimes, dentre elas o SUS e a PNSB, vislumbra-se agora a possibilidade muito ameaçadora de desmonte do SUS e das recentes conquistas sociais - ainda não consolidadas. O caso da bucal é emblemático quanto a essas possibilidades funestas, não há dúvidas. Pior, constrói-se socialmente de forma implacável e diária uma narrativa única de fracasso do SUS, no mesmo arco de atuação das forças neoconservadoras que exercem um ofício "missionário", negando o direito ao contraditório.

O Estado brasileiro acumulou uma dívida social enorme em termos de atenção em saúde bucal. Sequer a fluoretação da água de abastecimento é feita como prescrita pela legislação, e está é, das ações tecno-programáticas historicamente constituídas, a mais típica da SBC. No entanto, não se conseguiu romper o imaginário da "odontologia", isto é, da prática dental, que habita universos formativos do cirurgião-dentista e com ele o da própria sociedade, produzindo uma redução de objeto que se aproxima da violência simbólica. Faltou que, no âmbito do SUS e da prática coletiva da SBC, pudéssemos ter ido além das prescrições "pastorais", adereços retoricamente simpáticos como escovar os dentes e controlar o consumo de açúcar. Sabemos que SBC é muito mais que isso. Mas no imaginário do gestor mediano, Brasil afora, tratava-se disso, aliado ao fato de que o sistema de informação e gestão/avaliação realçou demais essa perspectiva caricata, especialmente nas 
pactuações ministeriais com estados e municípios. Assim, a SBC veio a se tornar refém do mesmo enredo puericultor do passado. Quisemos, mas não atingimos nível de transcendência. Salvo costumeiras exceções, não dialogamos e produzimos com a sociedade um novo conceito acerca do cuidado, não nos ligamos compassivamente ao sofrimento das pessoas, não ajustamos a nossa agenda de trabalho cotidiano a nenhuma pauta social significativa. Falo de uma SBC que se manteve refém do antigo pacto de poder corporativo, de viés privatizante, liberal, dominado pelo ideário do mercado odontológico. Não faltaram teorias academicistas, mas faltou a excitação do desconforto e a tentativa de sair ao sol, de se arriscar, tomar chuva, pisar o chão da realidade onde o brasileiro comum, usuário do SUS, habita. Tudo bem, enquanto um determinado arranjo político conseguiu manter-se no Ministério da Saúde, a PNSB esteve mais ou menos preservada. Agora, sabe-se lá.

Como reagir aos fatos recentes da história brasileira? Como resistir? A afirmação do protagonismo da SBC como um coletivo, como um agente importante na manutenção e avanço da PNSB, exigirá um posicionamento claro diante da nova conjuntura; não mais ser tratada como uma franzina subárea ministerial de tempos passados. Agora, deveria ser vista como uma Política setorial que ganhou músculos e que extrapola uma "cadeira" ocupada no Ministério da Saúde. Esta Política - com "P" maiúsculo - envolve um conjunto enorme de atores e interesses os mais diversos, nas três esferas de governo, na sociedade, no mercado, na mídia e nas redes virtuais/blogosfera: movimentos sociais e organizações civis, conselhos do controle social, redes de atenção e gestão, academia - considerada no tripé ensino, pesquisa, serviço -, entidades corporativas, partidos e sindicatos, complexo industrial, dentre outros.

Porém, é preciso também evitar uma forma de illusio, uma concepção e prática ingênua de "pertencimento" ao campo da SBC, uma inocência de participar do jogo e de jogar pensando que as ações, sobretudo daqueles que parecem tão próximos e são "aliados”, seriam "desinteressadas” quanto a vaidades e exercício de micropoderes pessoais - ou se colocando à serviço de interesses maiores, não declarados. É possível abrir o jogo completamente ou o jogo tem que ser jogado e suas regras se dão a conhecer no próprio avanço do jogo? Alguns ficam animados com iniciativas parlamentares, tais como o Projeto de Lei $n^{\circ} 6836 / 17$, que altera a Lei Orgânica da Saúde (nº 8.080/90), criando a Política Nacional de Saúde Bucal no âmbito do SUS como ação permanente do Estado brasileiro e não apenas um programa governamental. Isto basta hoje, com o Estado brasileiro entregue às forças políticas atuais? Uma aliança tática, pontual, com o estamento burocrático do Ministério da Saúde, neste ano eleitoral de 2018, provavelmente seria apenas a 
repetição da máxima da aristocracia política italiana, desvelada no livro O Leopardo, de Giuseppe di Lampedusa: o príncipe de Falconeri diz que "tudo deve mudar para que tudo fique como está" - ou mais grave ainda, que tudo retroceda ao rés-do-chão.

A obra que agora o leitor tem em mãos, após ser lida em sua completude, pode nos inspirar ao revelar estratégias que nos permitiram no passado superar e avançar sobre conjunturas tão ou mais difíceis do que a que vivemos hoje. A autora nos sussurra suavemente, nas entrelinhas: "tudo deve mudar, com orientação para as necessidades e para a resolução de problemas do povo brasileiro!”.

Curitiba, maio de 2018.

\section{Samuel Jorge Moysés}




\section{INTRODUÇÃO}

Este livro é um produto da tese de doutorado de Thais Regis Aranha Rossi, sob a orientação da prof ${ }^{a}$. Lígia Vieira e coorientação do prof. Patrice Pinell, do Centre Européen de Sociologie et de Science Politique (CESSP/Paris). O trabalho faz parte do Observatório de Análise de Política do Instituto de Saúde Coletiva da Universidade Federal da Bahia (UFBA), coordenado pelo prof. Jairnilson Paim. O presente estudo busca contribuir para a compreensão do complexo processo de formulação das políticas de saúde bucal no Brasil, com vistas a interpretar melhor cenários futuros. Os capítulos desta obra apresentam a análise realizada em cada conjuntura política.

A análise das políticas pode ser feita à semelhança de muitos estudos históricos que se restringem à descrição e comprovação dos fatos ou buscando interpretar os acontecimentos a partir da formulação de problemas. (BLOCH, 2001; BOURDIEU, 2012) A primeira alternativa foi criticada pelo historiador Bloch (2001) que considerava o fato histórico não como um fato "positivo", ${ }^{1}$ mas como produto de uma construção ativa decorrente da transformação da fonte em documento e deste em problema. Na mesma direção, o sociólogo Bourdieu (2012) considerou o estudo da história como fundamental para a análise do mundo social, tanto como técnica de ruptura com o senso comum, quanto como abordagem potencial para auxiliar a compreensão de problemas atuais.

O uso da abordagem histórica em estudos sobre objetos ligados à saúde tem contribuído para a desconstrução de algumas pré-noções, consideradas "naturais", a exemplo da análise feita por Lenoir (1996) sobre a idade e a velhice. Este autor mostrou que o significado destas categorias variou segundo épocas e regiões

1 Marc Bloch (2001) critica os historiadores positivistas, sempre manifestando sua preocupação em distinguir os historiadores peculiares dos sistemáticos. O sentido do positivismo recriminado é aquele "que se tinge de utilitarismo", quando os historiadores reduzem o trabalho histórico ao que parece capaz de "servir à ação". 
como resultado de lutas, servindo de base para a construção da realidade social. (LENOIR, 1996)

Do ponto de vista das políticas de saúde, dentre os estudos que utilizaram esta perspectiva, destacam-se aqueles desenvolvidos por Pinell (2010), em sua investigação sobre a interação dos diversos processos e espaços relacionados com a construção social de uma política, na França, entre 1982 e 2005, nos casos da luta contra o câncer, a AIDS, na invenção da escala métrica da inteligência e na especialização da medicina. O autor aponta que o Estado intervém de forma a adotar medidas a fim de organizar uma resposta social qualificada de "luta contra" doença ou flagelo que ameace a sociedade. Esta perspectiva está presente, também, em estudos brasileiros, como o de Vieira-da-Silva e Pinell (2014), sobre a gênese da saúde coletiva; de Barros (2013), sobre a política e o espaço de luta contra a AIDS; e de Souza (2013), que estudou a gênese do Programa de Incentivo Fiscal à Alimentação do Trabalhador no país.

No que diz respeito, especificamente, às políticas de saúde bucal, estas têm sido estudadas sob diversos enfoques. Algumas publicações tratam das respostas do Estado em seus países ou continentes. Apoiados em fontes bibliográficas, Wright e List (2012) descreveram as políticas de saúde bucal na Austrália, no período compreendido entre 1890 e 2012, apontando um grande componente privado no sistema de saúde com foco individualista, biológico e na clínica. Os autores concluíram que as mudanças nos serviços públicos odontológicos no país devem se basear nas necessidades e demandas de saúde bucal, considerando o contexto e os determinantes sociais de saúde da população.

Revisão da literatura sobre morbidade e mortalidade relacionadas a doenças bucais na África, no período compreendido entre 1850 e 1997, com o objetivo de examinar a origem do problema de acesso aos serviços odontológicos, demonstrou a incompatibilidade entre os serviços existentes e as doenças bucais prioritárias nos países africanos. As doenças mais prevalentes foram estomatite gangrenosa (Noma), Gengivite Ulcerativa Necrosante Aguda (GUNA), manifestações orais do HIV/AIDS, traumas maxilofaciais e anormalidades congênitas. Os autores concluíram que as estratégias coloniais de organização dos serviços de saúde bucal, tal como outras exportadas para a África, não vêm respondendo aos problemas daquela população. À época da publicação do artigo, 700 milhões de pessoas não tinham acesso adequado a serviços odontológicos. Aproximadamente, $80 \%$ das comunidades africanas eram consideradas materialmente desprovidas, tendo sido a pobreza considerada o maior determinante dos problemas de saúde. A formulação de políticas de saúde bucal esteve presente em apenas 30\% dos países do continente 
com serviços não organizados em distritos e desarticulados dos outros serviços de saúde. (HOBDELL et al., 1997)

Foram, também, localizados estudos sobre a cobertura de grupos etários específicos, como a revisão feita na Índia, que mostrou a ausência de política de saúde bucal específica para a população idosa naquele país. (SHAH, 2004) Existem ainda estudos descritivos sobre os principais serviços odontológicos, seu financiamento, as doenças bucais mais prevalentes, assim como a formação de recursos humanos em Odontologia em alguns países, como na Austrália (SCHWARZ, 2006) e na França. (AZOGUI-LÉVY; BOY-LEFÈVRE, 2005) Outro trabalho discutiu as políticas de saúde bucal e sistemas de saúde no cenário internacional e nacional a partir de revisão documental e da literatura. (MOYSÉS, 2008) O autor identificou o sistema de saúde e os serviços de saúde bucal da Alemanha, Reino Unido, países escandinavos, Canadá, Cuba, Estados Unidos, assim como descreveu políticas de saúde bucal e as principais Conferências Nacionais de Saúde Bucal ocorridas no Brasil, da década de 1980 aos anos 2000. As maiores prevalências de edentulismo em idosos foram na Islândia, Albânia, Canadá e Malásia, tendo sido relacionadas aos aspectos particulares da doença cárie e aos determinantes sociais em cada país. A política Brasil Sorridente foi apontada como recente e tendo potencial, mas não ainda operando com capilaridade e solidez política para enfrentar questões estruturais e que determinam as iniquidades em saúde bucal e de utilização dos serviços nos diferentes níveis de complexidade. (MOYSÉS, 2008) Não foram encontrados estudos sócio-históricos das políticas de saúde bucal, na perspectiva referida, na literatura internacional revisada.

No Brasil, as políticas de Saúde Bucal (SB) no cenário federal vêm sendo estudadas por muitos autores, publicadas como dissertações, teses, artigos, livros e capítulos de livros. Dissertação de mestrado sobre as características do subsistema odontológico público federal verificou aporte de recursos, considerado como significativo, para a assistência odontológica no Brasil, o que correspondeu a 13,63\% e 13,46\% dos gastos ambulatoriais nos anos de 1976 e 1977, quando comparado aos gastos com toda a assistência médica em ambulatórios e unidades de saúde do Fundo de Assistência ao Trabalhador Rural (Funrural), do Instituto Nacional de Previdência Social (INPS) e da Fundação Serviços de Saúde Pública (FSESP). A FSESP contribuía com apenas $0,4 \%$ dos recursos e $1 \%$ das horas/profissional disponíveis no âmbito central. Os órgãos previdenciários, INPS e Funrural, atendiam a maior parte da clientela por livre demanda. (PINTO, 1977) Entretanto, havia pouca repercussão sobre os níveis de saúde bucal da população, com elevada prevalência de cárie dental e doença periodontal, sinalizando geométrico crescimento 
de necessidades de saúde pela população, devido à inexistência de uma política definida ou de normas que proporcionassem integração aos Ministérios da Saúde (MS) e da Previdência e Assistência Social (MPAS) e de uma estrutura adequada, segundo o Pinto (1977).

O trabalho também apontou a baixa cobertura dedicada ao atendimento das classes média e alta; a impossibilidade de prestação de cuidados a toda a população, pelo volume de problemas e fatores estruturais, como o desnível entre os preços do tratamento e a capacidade de custeio individual; a maciça concentração de insumos na área curativa e na zona urbana; o não seguimento de um esquema de prioridades; largo emprego de serviços contratados sob critérios essencialmente numéricos; e a utilização quase exclusiva de recursos humanos de nível universitário e de equipamentos sofisticados e pouco adaptados ao tipo de trabalho realizado, o que proporcionava escassa cobertura efetiva quando se praticavam os tratamentos completados. Por fim, Pinto (1977) sugeriu um programa nacional voltado para o escolar de $1^{\circ}$ grau, da zona urbana, a generalização de medidas preventivas assim como a utilização de recursos humanos e equipamentos simplificados.

Outro estudo que também utilizou como estratégia de produção dos dados a análise documental e fontes bibliográficas, tendo como período de análise $1974 \mathrm{a}$ 1985, verificou a ampliação da participação do Estado no que diz respeito à atenção odontológica, atrelada à expansão da assistência médica, a partir da década de 1970, entretanto, com caráter secundário, pouco sistematizado e fragmentário na saúde pública e previdenciária. (VIANNA, 1988) Na assistência odontológica previdenciária, o estudo apontou para a compra de serviços, o beneficiamento dos produtores privados de bens e serviços e o alto custo dos serviços. Assim, o Estado passava a contribuir para a ampliação do mercado privado na Odontologia. Analisando os dados fornecidos pela Empresa de Tecnologia e Informações da Previdência Social (Dataprev), a Vianna (1988) apontou que, em 1975, 45,4\% dos odontólogos eram credenciadosà previdência; já em 1976, os credenciados eram $60,8 \%$. Na zona urbana, houve aumento do número de consultas odontológicas e ampliação do setor credenciado de 1976 a 1979. No caso da zona rural, houve redução no número de consultas. A autora também citou a promulgaçãoda primeira Lei de Fluoretação das Águas, em 1974, mas verificou que sua implementação ficou na dependência de convênios com instituições. No período de 1980-1985, constatou-se a ampliação do setor conveniado e redução dos serviços próprios. (VIANNA, 1988)

Outro pesquisador analisou as políticas de saúde bucal, na década de 1980, através de análise documental, fontes bibliográficas e entrevistas, tendo apontado 
para a ausência de resposta concreta e significativa pelo Estado até o início da década de 1990, apesar de a década anterior ter representado um período de organização institucional do Ministério da Saúde e de enfraquecimento da estrutura previdenciária. (ZANETTI, 1993)

A política de Procedimentos Coletivos (PC) lançada no início da década de 1990, na Coordenação Nacional de Saúde Bucal exercida pelo cirurgião-dentista Sergio de Carvalho Weyne, teve seu percurso analisado, desde seu surgimento até sua extinção. (CARVALHO et al., 2009) A publicação analisa os PC criados no governo Collor como elemento central da sua política de saúde bucal. Durante os anos 1990, os procedimentos ocuparam lugar de destaque nas ações de saúde bucal no Sistema Único de Saúde (SUS), impulsionando, com apoio financeiro, as ações de promoção e prevenção em centenas de municípios. Os autores concluíram que a política foi uma tentativa para alterar o modelo de prática odontológica no setor público, redirecionando-o para ações preventivas e de promoção da saúde.

Atinente ao período de 1988 a 2004, Assis (2006) analisou as políticas de saúde bucal formuladas e implementadas no nível federal, tendo apontado a expansão dos serviços de saúde bucal através de análise documental e revisão da literatura. Segundo esta autora, no governo Sarney, não se avançou quanto à organização dos serviços e práticas de atenção à saúde bucal. No governo Collor, a autora concluiu por uma indefinição de propósitos, devido ao conteúdo limitado ao tema no plano quinquenal. No mandato do presidente Fernando Henrique Cardoso, ressaltou-se a inclusão da saúde bucal no Programa de Saúde da Família (PSF). Já no governo Lula, manteve-se o contingenciamento das verbas para saúde, contudo as implementações das políticas de saúde bucal ganharam destaque através não só da ampliação de incentivo para implantação proporcional entre Equipes de Saúde Bucal (ESB) e Equipes de Saúde da Família (ESF), como também da criação de incentivos para Centro de Especialidades Odontológicas (CEO) e Laboratórios Regionais de Prótese Dentária (LRPD), assim como aumento do incentivo em saúde bucal para municípios com baixo Índice de Desenvolvimento Humano (IDH). (ASSIS, 2006) O estudo tratou das políticas formuladas e implementadas em nível nacional a partir dos componentes de um sistema de saúde e não abordou o processo de produção social.

Associando as políticas nacionais de saúde bucal do Brasil e sua interface com as iniciativas governamentais para combate à pobreza, miséria e exclusão social, entre 1995 e 2013, Lorena Sobrinho (2014) afirmou que o ano de 2004 foi favorável à entrada da saúde bucal na agenda de prioridades, sendo fácil a tomada de decisão pela implantação após formulação ampla e participativa do seu conteúdo. 
Houve aumento do escopo das ações e serviços de saúde bucal nos diversos níveis de complexidade, com foco em populações excluídas, como índios, moradores de zona rural, de áreas quilombolas, fluviais e ribeirinhas e em pacientes com necessidades especiais. Foram criados 816 Centros de Especialidades Odontológicas e 1.465 Laboratórios Regionais de Prótese Dentária. Apesar das altas proporções de cirurgiões-dentistas por habitantes, segundo dados do Conselho Federal de Odontologia, ainda há uma concentração destes profissionais no Sul e Sudeste. Desigualdades regionais se mostraram marcantes como também os vazios assistenciais no Norte. Verificou-se impactos na situação de saúde quanto à redução do número de dentes perdidos e do índice CPO-D em todas as faixas etárias.

Machado (2006), analisando as políticas de saúde nos anos 1990, abordou a centralidade do PSF na agenda do MS, identificada através da adoção de um incentivo financeiro específico, o que representou aumento de, aproximadamente, 900\% dos recursos entre 1995 e 2002; crescimento da participação do PSF nos gastos com atenção básica; implementação de polos de capacitação em saúde da família; instrumentos gerenciais e estratégias diferenciadas de assistência para o PSF, a partir de 2001. Dentre tais estratégias, a inclusão da saúde bucal no programa foi relacionada à prioridade atribuída pelo governo ao próprio PSF.

Sobre a inclusão da saúde bucal no Programa e a formulação da Política Brasil Sorridente, Garcia (2006) buscou compreender o processo de construção da Política Nacional de Saúde Bucal (PNSB), no período de 2000 a 2004, mas sob a perspectiva do MS. A autora discorreu sobre a inclusão da saúde bucal no PSF, abordando que a iniciativa sobreveio através da busca da organização do espaço institucional pela coordenação do setor e de recursos financeiros, por meio de uma janela de oportunidades na atenção básica aproveitada pela gestora. (GARCIA, 2006) A coordenação nacional é apontada como a figura central presente no movimento para a construção da proposta, que lutou internamente ao Ministério, definiu determinadas questões e negociou com atores externos.

No Brasil Sorridente, foi referido que o processo partiu de um amplo debate realizado por um grupo de intelectuais e profissionais de saúde, muitos da saúde bucal, militantes do Partido dos Trabalhadores (PT) e de partidos da coalizão. (GARCIA, 2006) No governo Lula, o grupo transformou o projeto Brasil Sorridente em política que manteve conexões com o projeto da reforma sanitária. A autora não encontrou evidências da participação significativa, em ambos os momentos de formulação, de atores chamados de externos, ou seja, que não eram funcionários do Ministério da Saúde, envolvidos no processo. (GARCIA, 2006) É pertinente ressaltar que o estudo foi conduzido a partir da análise de documentos institucionais e de entrevistas com 
agentes do campo burocrático; neste sentido, a autora não analisou o espaço de formulação das políticas.

Essas duas políticas também foram estudadas por Rendeiro (2011) cujo trabalho abordou a formação incremental do ciclo da PNSB. A autora identificou três ciclos de inovação: saúde bucal, no Programa de Agentes Comunitários de Saúde (PACS); saúde bucal, no PSF, em 2000; e a publicação das diretrizes da PNSB, em 2004. Quanto à inclusão da ESB na saúde da família, abordou que a questão não fazia parte da agenda governamental e foi alçada a agenda de decisão através do resultado da Pesquisa Nacional por Amostra de Domicílios (PNAD) (1998), surgindo uma oportunidade. Citou que os atores que desempenharam protagonismo no processo foram o ministro da Saúde e servidores próximos a ele, concordando com Garcia (2006), em interação com os consultores do MS, que exerceram baixa influência no processo, sem a presença do controle social nos processos decisórios nem do empreendedor de políticas.

Quanto à política Brasil Sorridente, a autora considerou que este processo foi permeado pela militância com a correlação entre a técnica e a política, que encontrou como facilitador o amadurecimento das ideias de um grupo com militância política e setorial e das relações deste com o presidente eleito, além da participação de um dentista chamado de empreendedor da política, que exerceu uma influência cotidiana junto ao presidente e facilitou a interlocução direta com este. (RENDEIRO, 2011) Neste estudo, também se privilegiou a análise sob o ponto de vista dominante do campo burocrático, principalmente no caso do PSF, em detrimento dos outros agentes.

Outras publicações abordam os principais fatos relativos às políticas de saúde bucal ao longo dos anos. Esses trabalhos tratam do percurso histórico das políticas de saúde bucal no período anterior e/ou posterior ao SUS, no século XX e XXI (BITTAR et al., 2009; LUCENA; PUCCA JÚNIOR; SOUSA, 2011; MOYSÉS, 2014; NARVAI; FRAZÃO, 2008a, 2008b; PUCCA JÚNIOR et al., 2009), da associação das políticas de saúde bucal aos movimentos ideológicos (NARVAI, 2006; SOARES, 2012), dos 20 anos das políticas de saúde bucal no SUS (FRAZÃO; NARVAI, 2009; MANFREDINI, 2009); da evolução da fluoretação das águas (ANTUNES; NARVAI, 2010); assim como do processo de construção de vigilância à saúde bucal desde 2004. (MOYSÉS et al., 2013)

Sobre a política Brasil Sorridente, Bartole (2006) analisou documentos importantes para a política e suas diretrizes, tendo afirmado que a equipe utilizou uma manobra retórica para expor suas ideias e para consolidar uma política de saúde bucal. Nas diretrizes, o Ministério da Saúde propunha uma Política Nacional de 
Saúde Bucal (PNSB) e balizou como eixo central a reestruturação e a reorganização da atenção à saúde bucal, assegurando a qualidade e a resolutividade na atenção básica e em todos os níveis de atenção, incluindo todas as faixas etárias da população. Entretanto, afirmou que o Brasil Sorridente surgiu como um espaço político no governo federal, de maneira privilegiada e destacada, no SUS, tendo utilizado o marketing político para traduzir uma marca do governo federal a entrar na história da saúde pública brasileira.

Narvai (2011) aponta para a existência de uma longa gênese para a política Brasil Sorridente e refuta hipótese de estudos anteriores, como os de Bartole (2006) e Garcia (2006), que abordam a janela de oportunidades, colocando-se como agente e militante de um longo processo histórico que tem suas origens na luta contra a ditadura militar e ganhou expressão técnico-política no Encontro Científico de Estudantes de Odontologia (ECEO), no Encontro Nacional de Administradores e Técnicos do Serviço Público Odontológico (Enatespo) e nos congressos de Saúde Coletiva, conferências de saúde e de algumas entidades odontológicas como a Federação Interestadual dos Odontologistas (FIO), Associação Brasileira de Odontologia Preventiva (Aboprev), assim como do Movimento da Reforma Sanitária e o Movimento Brasileiro de Renovação Odontológica (MBRO). O autor baseou sua análise em revisão bibliográfica e documental, realizando breve descrição de processos sociais relacionados à formulação da política.

Segundo Andrade (2008) a análise das relações de poder na elaboração da política Brasil Sorridente foi descrita a partir do encadeamento factual. A autora analisou a formulação da política Brasil Sorridente, tendo dividido os participantes da formulação em dois grupos: individuais e coletivos. O primeiro deles, coeso, foi formado por indivíduos identificados com o projeto político vitorioso nas eleições presidenciais de 2002 e que possuíam um passado de luta na construção do SUS. O segundo grupo teve a função de dar consentimento à formulação do primeiro. A PNSB foi composta por um conjunto de deliberações oriundas de vários momentos de discussão, com destaque para um encontro realizado no município de São Paulo, logo após o resultado do pleito eleitoral referente à candidatura à presidência da República de Luiz Inácio Lula da Silva, em 2002. Foram apontados o crescimento e a degradação da PNSB, como erosões internas, em especial a gerência imprópria dos recursos financeiros e a tendência de ela ser, cada vez mais, caracterizada como provedora de serviços odontológicos especializados. O estudo apontou os chamados "atores coletivos" que participaram do processo, mas não analisou os "atores individuais" que influenciaram a formulação da política. Acerca destes últimos, foram apresentadas características gerais, todavia, a autora não 
analisou quem são esses agentes, sua trajetória, assim como não tratou da evolução das políticas de SB.

Sobre a organização tecnológica na política Brasil Sorridente, assim como os modelos de atenção que alicerçaram as políticas de saúde bucal desde a década de 1950, Pires (2013) apontou como desafio para a PNSB de 2004 aquele de produzir cuidados de saúde bucal na perspectiva do coletivo, da comunidade. A erradicação da cárie dentária apareceu, ao longo dos anos, nas políticas, tendo como base a vigilância da saúde e as informações epidemiológicas. A autora não localizou no discurso da PNSB outras alternativas para abordar os problemas bucais que não fossem escovação dental, controle da dieta e correlação de hábitos deletérios. (PIRES, 2013) Concluiu que o trabalho em saúde bucal ainda se concretiza como um trabalho de Odontologia e há falta de maior elaboração teórico-prática sobre uma tecnologia para o cuidado do sujeito com suas necessidades bucais. (PIRES, 2013; PIRES; BOTAZZO, 2015)

Os estudos revisados trazem contribuições à compreensão da evolução histórica das políticas de saúde bucal. Por meio deles, é possível destacar o aumento da participação do Estado brasileiro na formulação e implementação dessas políticas, a partir de meados da década de 1970 (VIANNA, 1988), na década de 1980 (VIANNA, 1988; ZANETTI, 1993, 1994), assim como, de forma subsequente até 2004. (ANDRADE, 2008, ASSIS, 2006; BARTOLE, 2006; GARCIA, 2006) Trabalhos mais recentes, como os de Teixeira e Paim (2005), Lucena, Pucca Júnior e Sousa (2011), Machado, Baptista e Nogueira (2011) e Narvai (2011), apontam priorização da política de saúde bucal, intitulada Brasil Sorridente a partir de 2004, reconhecida como uma das marcas governamentais, nos oito anos do mandato do então presidente Luís Inácio Lula da Silva. Dois desses estudos apoiaram sua análise em dados da expansão do número de equipes implantadas e do financiamento. (MACHADO et al., 2011; TEIXEIRA; PAIM, 2005) Ademais, apesar de alguns estudos afirmarem que não houve participação significativa de atores externos ao MS em determinadas políticas, não foram entrevistados membros das associações e entidades de classe ou analisados os boletins e publicações destas instituições.

Esses estudos têm se apoiado em descrições sobre o surgimento e desenvolvimento das políticas de saúde bucal. As razões acerca da sua emergência na conjuntura específica têm sido pouco investigadas. Também tem sido secundarizada, na análise da formulação das políticas de saúde bucal, a construção social por meio do estudo dos principais agentes envolvidos, suas trajetórias, as questões em disputa no espaço bem como suas relações com as condições históricas de possibilidade no sentido proposto por Bourdieu (2012) para a análise de espaços sociais. 
Diante da revisão realizada, diversas perguntas ou não foram elucidadas pelos estudos publicados ou permanecem parcialmente respondidas, conforme explanado anteriormente: como se conforma o espaço de formulação das políticas de saúde bucal nos distintos períodos? Quem foram os agentes responsáveis pela formulação dessa política? Qual a sua inserção no que diz respeito aos diversos campos do espaço social envolvidos com a atenção à saúde bucal? Ainda, qual o espaço dos possíveis históricos que estiveram relacionados ao curso das políticas e como se deu esse processo? Quais as relações e as influências exercidas pelos campos político, científico e burocrático na formulação das políticas de saúde bucal no Brasil? O objetivo geral era analisar a produção social das políticas de saúde bucal no Brasil, de 1989 a 2004.

Os objetivos específicos foram analisar como os problemas de saúde bucal se tornaram problemas sociais no Brasil, de 1989 a 2004; analisar a emergência das principais respostas do Estado brasileiro aos problemas bucais da população; analisar os processos relacionados com continuidades e/ou rupturas na história das políticas de saúde bucal no Brasil. Esse estudo almejou contribuir com respostas a essas questões, por meio de estudo sócio-histórico acerca da produção social das principais políticas de saúde bucal no Brasil.

\section{Metodologia utilizada para construção deste trabalho}

Aqui nos deteremos a apresentar brevemente a metodologia utilizada para a construção deste estudo.

\section{Referencial Teórico}

A sociologia reflexiva e genética de Pierre Bourdieu foi adotada como referencial teórico deste trabalho. A compreensão sobre o processo de produção social das políticas de saúde bucal no Brasil implicou a análise do espaço de formulação dessas políticas no nível federal. Os agentes ${ }^{2}$ ou grupos de agentes que participaram ou influenciaram na formulação das políticas de saúde bucal estavam situados em

Bourdieu (1983) utiliza o conceito de agente social para escapar ao de sujeito defendido pelas chamadas "filosofias do sujeito", na qual o objeto é o próprio sujeito, sendo alvo de crítica e refutação. Opõe-se também ao "sujeito criador", subjetivamente autônomo e orientado, quanto ao curso da ação de forma mecânica. $O$ ator também não traduz sua concepção de agente social, tendo em vista que considera segundo a teoria da ação racional, sendo livre de todo condicionamento social e econômico. (VIEIRA-DA-SILVA et al., 2016) Por sua vez, também se distancia da ideia de "indivíduo separado" pois esta relaciona-se ao materialismo espontâneo, à apreensão ingênua do corpo. O agente social está ligado a um campo, no interior do qual a proximidade não está relacionada ao espaço físico e sim às propriedades do campo. (BOURDIEU, 2007) 
um lugar do espaço social definido pelas suas propriedades relativas, a saber: volume global de capital e sua composição (capital científico, burocrático e político, principalmente) e trajetória social. O espaço social também pode ser descrito como um campo de forças entre os agentes, na medida em que as propriedades consideradas para a sua constituição, como as diferentes espécies de poder ou capital, são atuantes. (BOURDIEU, 2007) Para o autor, o conceito de espaço social nunca deve ser examinado em si mesmo e por si mesmo, devendo ser utilizado e posto à prova em uma pesquisa inseparavelmente teórica e empírica.

Verifica-se que Bourdieu (2001) utilizou o conceito de campo e espaço sociais, por vezes, como sinônimos. Porém, construiu teoricamente o conceito de campo como microcosmos sociais relativamente autônomos, espaços estruturados de posições ocupadas pelos agentes sociais. Cada campo possui suas leis específicas, seus objetos de disputas, seus habitus ${ }^{3}$ e interesses específicos - illusio ${ }^{4}$ (BOURDIEU, 1983) - e sua estrutura é definida a partir de sua própria história. Princípio gerador e unificador do conjunto das práticas de um grupo de agentes, o habitus corresponde ao sistema de disposições socialmente construídas e produtos de uma aquisição histórica. (BOURDIEU, 2011) É a adesão tácita às leis do campo (BOURDIEU, 2007), o investimento ligado a interesses específicos (BOURDIEU, 2002), constituindo o campo como espaço de jogo. (BOURDIEU, 2001) Ao utilizar a figura do jogo para explicar sua teoria, o autor busca tratar de um conjunto de pessoas que participa de uma atividade que obedece a certas regularidades. (BOURDIEU, 2002)

A estrutura dos campos que influenciaram as políticas de saúde bucal foi estudada através da relação de forças entre os agentes ou instituições engajadas na luta assim como na distribuição dos capitais específicos, acumulados em lutas pregressas e que, por sua vez, determinaram as estratégias de ação. A estratégia é produto do senso prático como sentido do jogo ou um domínio prático da lógica que se adquire pela experiência e que funciona aquém da consciência e do discurso. (BOURDIEU, 2002) É na dinâmica do jogo que se constrói a definição do problema social como um produto de diferentes estratégias dos grupos de agentes. (PINELL, 2010)

3 Habitus, no singular, é o princípio gerador e unificador que "retraduz as características intrínsecas e relacionais de uma posição em um estilo de vida unívoco, isto é, em um conjunto unívoco de escolhas de pessoas, de bens e de práticas". (BOURDIEU, 1996)

4 Cada agente faz uma série de investimentos que o tira da indiferença e lhe confere certa importância, desta forma, pode-se introduzir o conceito de illusio enquanto fundamento da concorrência que opõe os agentes e que constitui o próprio jogo, sendo assim um investimento em questões especificas que estão em jogo no espaço social. 
Cada posição no campo é definida a depender do acúmulo das diversas espécies de capital pelos agentes bem como pelas relações estabelecidas com outras posições que constituem a estrutura de posições do espaço social específico. (BOURDIEU, 1996) O capital cultural é herdado da família ou adquirido na escola. Ele é maior conforme for o reconhecimento das competências avaliadas pelo sistema escolar e se refere aos conhecimentos e/ou bens culturais adquiridos assim como à posse de títulos. (BOURDIEU, 2008) O capital econômico corresponde ao acúmulo de bens materiais (propriedades, rendimentos, salários), mas não apenas a este acúmulo e sim ao reconhecimento que este acúmulo confere ao agente. (BOURDIEU, 1983) Já o capital social, um capital de relações, se refere ao conjunto de recursos atuais ou potenciais ligados à posse de uma rede durável de relações mais ou menos institucionalizadas de conhecimento e de reconhecimento mútuo. Essas ligações são baseadas em trocas materiais e simbólicas. (BOURDIEU, 1980) O capital político se refere à força de mobilização que um agente detém por título pessoal, delegação ou por ser mandatário de organização detentora do próprio capital político acumulado e pode ser acumulado através de postos ou de militância decorrentes de lutas passadas. Este capital, também simbólico, se traduz como capital pessoal de notoriedade e de popularidade, firmado pelo fato de ser conhecido e reconhecido, é composto pelo capital de delegação que, ao contrário do capital pessoal, não desaparece com o seu portador, pois é detido e controlado pela instituição e só por ela. (BOURDIEU, 2001) O capital simbólico, de reconhecimento, não é uma espécie particular de capital. (BOURDIEU, 2007) Ele é uma propriedade de qualquer tipo de capital, físico, econômico, cultural, social, percebida de acordo com as categorias de percepção, princípios de visão e de divisão, esquemas cognitivos, que são produtos da estrutura da distribuição do capital no campo considerado e reconhecida pelos agentes. (BOURDIEU, 1996)

No que se refere ao capital científico, existem duas espécies: um poder institucional ou institucionalizado, temporal ou político, ligado à ocupação de cargos importantes em instituições científicas e ao poder assegurado por estas instituições sobre os meios de produção como contratos, créditos, postos e reprodução, entendido como o poder de nomear e de fazer carreira. Outra espécie de capital científico é pessoal, simbólico, pois se trata do reconhecimento objetivado, institucionalizado e pelos pares. Essas duas espécies de capital científico apresentam diferentes formas de acumulação. O capital científico propriamente dito, chamado de puro, é adquirido por contribuições reconhecidas ao progresso da ciência como, por exemplo, as publicações. Já o capital institucionalizado, decorrente da ocupação de cargos, embora requeira algum grau de capital especificamente cien- 
tífico, é adquirido principalmente por estratégias políticas que têm em comum o fato de exigirem tempo, como a participação em bancas, comissões, colóquios, reuniões. (BOURDIEU, 2004) O capital burocrático se refere aos cargos ocupados, ao poder de nomeação e delegação de funções públicas atribuídas pelo Estado, assim como à distribuição de honrarias. Esse capital é responsável por atos de consagração e por garantir as cadeias de delegação, assim legitima atos de autoridade. Está presente nos discursos oficiais, nomeações e atestados pelo Estado. (BOURDIEU, 1996, 2012)

Este estudo também se apoiou na proposta de Patrice Pinell (2010) para a análise sócio-histórica das políticas de saúde que utilizou o conceito de espaço social para alguns espaços específicos de construção ${ }^{5}$ de políticas onde agentes de diversos campos interagem com habitus diferenciados, porém partilham de um mesmo interesse na questão em jogo no espaço específico. Neste estudo, utilizou-se, nesta perspectiva, o conceito de espaço de construção da política de saúde bucal como um espaço de relações entre agentes de campos diferentes e que têm interesses em comum ligados a uma política, a de saúde bucal.

O conceito de política foi compreendido enquanto "a participação no poder ou a luta para influir na distribuição de poder, seja entre Estados ou entre grupos dentro do Estado" (WEBER, 1982, p. 56) e política de saúde, segundo Paim (2003, p. 588), como:

A resposta social (ação ou omissão) de uma organização (como o Estado) diante das condições de saúde dos indivíduos e das populações e seus determinantes, bem como em relação à produção, distribuição, gestão e regulação de bens e serviços que afetam a saúde humana e o ambiente.

Entretanto, o presente estudo privilegiou, em sua análise, as respostas sociais formalizadas traduzidas em ações. O conceito de espaço social é um recurso sociológico que permite estudar a estrutura e a dinâmica das relações mantidas pelos agentes envolvidos nas disputas em torno de um objetivo comum. (PINELL, 2010) O autor afirma que nenhum estudo "pode prescindir de uma análise concreta das forças que geram esse espaço social” (PINELL, 2010, p. 20 ), das relações, das estratégias e dos interesses envolvidos. De acordo com Bourdieu (2007), a reconstrução de um processo de emergência histórica não se reduz a um puro e simples encadeamento de acasos, ela implica a busca da elucidação de uma lógica específica.

5 Aqui, construção de políticas se refere a todo o processo que resulta na formulação da política e não apenas na sua elaboração como documento. 
O autor referia que a pesquisa genética ou estudo de gênese poderia fazer lembrar que o Estado e tudo que dele decorre é uma invenção histórica, servindo de antídoto ao que ele chamou de "amnésia da gênese". A "amnésia da gênese" é um processo inconsciente "[...] inerente a toda institucionalização exitosa, a toda instituição que conseguiu se impor implicando o esquecimento de sua gênese”. (BOURDIEU, 2012, p. 166)

Bourdieu (1996) considerava o Estado como um meta-campo com poder sobre os outros campos e que se superpunha ou mesmo correspondia ao campo burocrático. Por esta razão, analisar a formulação das políticas ou o processo social por meio do qual elas são socialmente produzidas implicou analisar o campo burocrático, embora os agentes envolvidos, muitas vezes, pertencessem a diversos outros espaços sociais envolvidos na construção do problema objeto da política como problema social. Para analisar as políticas de saúde bucal no Brasil, enquanto respostas formalizadas do Estado, este estudo perpassou o campo burocrático em cujo interior estas políticas foram formuladas bem como a relação de seus agentes com outros campos.

No presente trabalho, adotamos o conceito de Estado proposto por Bourdieu (1996), enquanto resultado de um processo de concentração de diferentes tipos de capital: capital de força física ou de instrumentos de coerção, a partir da contribuição de Weber; capital econômico; capital cultural e capital simbólico. A concentração de capital simbólico constitui o Estado como detentor de um metacapital que acumula poder sobre todos os outros tipos de capital e também sobre seus detentores. Ainda segundo Bourdieu (2012), o Estado é um metacampo, ${ }^{6}$ um campo do poder, ${ }^{7}$ um campo relativamente autônomo que exerce um poder de centralização da força física e simbólica, constituindo-se como objeto de lutas.

Este estudo buscou compreender como os problemas de saúde bucal foram objeto de construção como problemas sociais, em cada momento histórico. Os problemas sociais são o produto de uma construção que compreende seu reconhecimento e sua legitimação como tal, sendo “[...] instituídos em todos os instrumentos que participam da formação da visão corrente do mundo social” (LENOIR, 1996,

"A construção do Estado como metacampo com o poder de construção de todos os campos [passa pela] construção de cada um dos campos" diz Bourdieu (2012, p. 271), que explica que, na concorrência entre os campos, cria-se uma espécie de poder "metacampo" que triunfa sobre todos os outros campos e dentro dele mesmo.

7 Campo do poder é definido enquanto relações de força entre as posições sociais que garantem, aos seus ocupantes, quantidade suficiente de capital que lhes possibilita entrar nas lutas pelo monopólio do poder. (BOURDIEU, 2001) Esse campo é o espaço das relações de força entre os agentes ou instituições que têm em comum possuir o capital necessário para ocupar posições dominantes nos diferentes campos (econômico ou cultural, especialmente). (BOURDIEU, 2012) O Estado é um campo do poder. 
p. 62-63), que pode ser nos organismos e regulamentações que visam encontrar uma solução ou mesmo nas "categorias de percepção e pensamento que lhe correspondem”. Os problemas sociais variam segundo as épocas e regiões e podem ser constituídos por vários motivos. Seu reconhecimento é tornar visível uma situação digna de atenção pela ação de grupos interessados em produzir nova categoria de percepção social para agirem sobre eles. Já sua legitimação envolve uma operação para inseri-lo nas preocupações sociais do momento.

Também foram utilizadas algumas das proposições elaboradas por Pinell (2010) a respeito das políticas de saúde, que, orientadas pela sociologia bourdieusiana, sugeriram questões específicas para a investigação da gênese e evolução das políticas de saúde que foram exploradas no presente estudo. A partir do estudo de quatro políticas de saúde distintas, Pinell (2010) elaborou proposições que dizem respeito a dois momentos diferentes das políticas de luta contra doenças ou práticas e comportamentos vistos como patológicos: a gênese, seguida de sua evolução. Essas propostas serviram de base para o presente estudo e nortearam a análise dos diversos momentos da história das políticas de saúde bucal, que investigou:

- em quais momentos as políticas de saúde bucal traduzidas em ação do Estado foram reconhecidas pelo poder público a partir da necessidade de medidas específicas para tratar problemas que não encontravam soluções satisfatórias já existentes; ${ }^{8}$

- como e se a ideia de reconhecimento pelo poder público implicou que os agentes do campo burocrático no interior do Estado reassumissem a responsabilidade de análise prévia do problema que colocasse em questão a inadequação das orientações políticas e modalidades de organização e/ou práticas institucionais existentes;

- a dinâmica entre os grupos sociais envolvidos com a constituição dos problemas de saúde bucal como problemas sociais visando identificar as posições, tomadas de posição, alianças e acordos;

- o momento da construção social do problema de saúde bucal como problema que demanda a implementação de uma política. Houve negociação e ajustes para a elaboração de uma visão comum do problema ou ocorreram fases de conflito por concorrência entre grupos que têm um mesmo interesse em constituir o problema?; 
- a dinâmica do jogo social no qual se constrói a definição do problema como produto da interpenetração das estratégias dos diferentes grupos de agentes que se interessam em construir o problema como problema.

\section{Estratégia do estudo}

O presente estudo tratou do processo de construção das políticas de saúde bucal entre 1989 e 2004, período em que importantes ações a este respeito foram lançadas no cenário nacional. Para compreender o processo de construção do espaço de formulação das políticas de saúde bucal, buscou-se retratar a dinâmica do jogo social que se estabeleceu na relação entre grupos, as alianças formadas, o espaço dos possíveis inscritos no campo, os agentes envolvidos na construção dos problemas ou as doenças bucais como um problema social.

Como são muitas as respostas do Estado quanto aos problemas de saúde bucal contempladas em distintos atos deliberativos como portarias, programas, instruções normativas, decretos, leis, entre 1989 e 2004, para fins desta análise, foram considerados quatro momentos importantes que serviram como norteadores. No Quadro 1 constam estas formalizações, o período em que foram lançadas, seus objetivos, assim como quem exercia o cargo burocrático na saúde bucal, no Ministério da Saúde, e o chefe do executivo nacional, o presidente da República. As ações propostas em cada um dos documentos analisados foram expostas em suas sessões específicas. Estas políticas foram elencadas após revisão do estado da arte e por representarem as principais construções sociais no cenário nacional para as políticas de saúde bucal de 1989 a 2004.

O ponto de partida foi a Política Nacional de Saúde Bucal e o Programa Nacional de Controle da Cárie Dentária (Precad), ambos editados em 1989. A seguir, foram abordadas a política de procedimentos coletivos e a divergência entre a fluoretação da água x fluoretação do sal de cozinha, no início da década de 1990. A inclusão da saúde bucal no PSF, em 2000, e a política Brasil Sorridente, de 2004, também foram objetos desta análise.

A análise se apoiou em 33 entrevistas, sendo 32, em profundidade, com informantes-chave realizadas pela autora e uma entrevista concedida a Catharina Matos Leite Soares, no âmbito do projeto "A construção da Saúde Bucal Coletiva no Brasil", tendo sua utilização neste trabalho sido autorizada pelo entrevistado. A técnica da bola de neve foi utilizada a fim de compor a amostra com informantes representativos. 


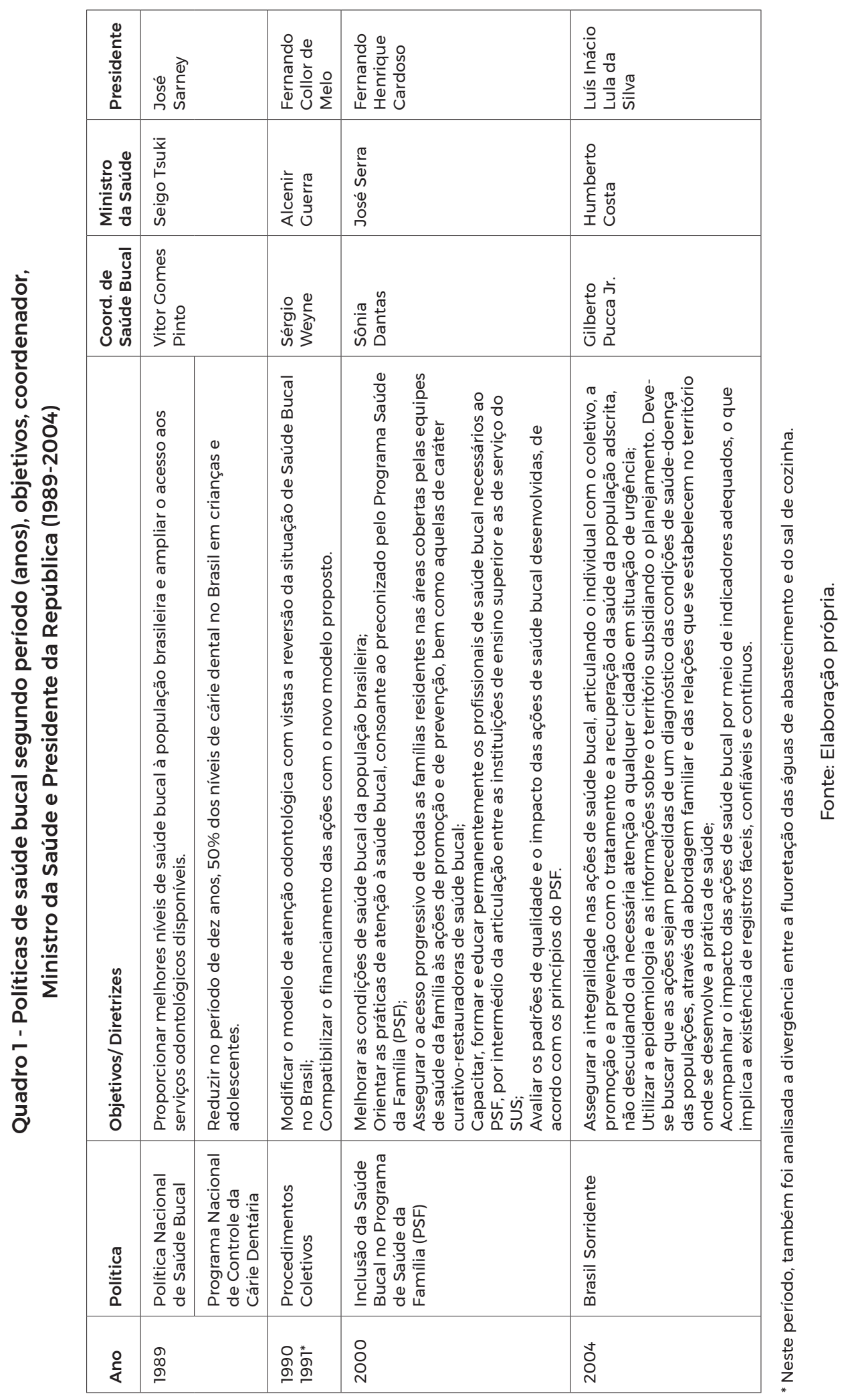


Buscou-se entrevistar agentes situados em posições diferenciadas em relação ao processo de formulação da política, na sua maioria, profissionais envolvidos com a construção social do problema e em posições dominantes nos campos, nos diversos períodos das políticas, mas, também, alguns em posições que podem ser consideradas como intermediárias em relação ao processo de formulação das políticas, dominantes-dominados ou dominados. Das 32 entrevistas, 31 foram conduzidas presencialmente nas seguintes cidades: Salvador (BA), Rio de Janeiro (RJ), Recife (PE), São Paulo (SP), Porto Alegre (RS), Brasília (DF), Curitiba (PR), Belo Horizonte (MG), Fortaleza (CE). Apenas uma foi realizada por telefone, gravada com consentimento verbal do entrevistado. Além das entrevistas em profundidade, os entrevistados foram contatados outras vezes, por telefone ou e-mail, quando houve necessidade de qualquer esclarecimento. As 32 entrevistas realizadas pela autora totalizaram 48 horas, 12 minutos e 37 segundos de gravações que foram transcritas e revisadas.

Foram consultados e analisados documentos institucionais do Ministério da Saúde, tais como discursos presidenciais, publicações do Diário Oficial da União, processos legislativos da Câmara e do Senado Federal, relatórios de conferências (Conferências Nacionais de Saúde e Conferências Nacionais de Saúde Bucal), encontros/congressos - Encontro Nacional de Administradores e Técnicos do Serviço Público Odontológico (Enatespo), congressos da Associação Brasileira de Odontologia de Promoção de Saúde (Aboprev), atas da Associação Brasileira de Saúde Bucal Coletiva (Abrasbuco), dentre outros, boletins e jornais de entidades de classe como o Conselho Federal de Odontologia (CFO), Associação Brasileira de Odontologia (ABO) e outras associações, como a Rede Cedros e Aboprev, assim como de sindicatos, como a FIO, boletins do Movimento Brasileiro de Renovação Odontológica (MBRO), memorandos, ofícios e abaixo assinados e matérias de jornais de grande circulação como o Correio Brasiliense, Folha de São Paulo e Estado de São Paulo.

Esses documentos foram coletados em bibliotecas, sites oficiais do governo federal, sites de jornais, entretanto, a grande maioria dos 593 documentos analisados foi cedida pelos agentes entrevistados neste trabalho. Os documentos que não sofreram objeção quanto à sua disponibilização foram digitalizados e serão tornados de amplo acesso através do Centro de Documentação Virtual do Observatório de Análise de Políticas do Instituto de Saúde Coletiva da Universidade Federal da Bahia (ISC/UFBA).

Os agentes que participaram ou influenciaram na formulação das políticas de saúde bucal foram analisados no que diz respeito às diversas posições ocupadas em diferentes espaços e campos sociais ao longo da sua trajetória. A posição 
ocupada foi caracterizada por meio do volume e da composição dos seus diferentes tipos de capital: escolar, científico, político e burocrático. Por meio da análise das posições ocupadas e das proximidades no espaço foram identificadas as propriedades em comum aos diversos agentes do espaço das políticas de saúde bucal. $O$ ponto de vista analisado foi relacionado com a posição ocupada em determinado momento histórico.

Esses agentes foram analisados a partir dos seguintes indicadores (posições e tomadas de posição, indicativas das disposições):

- Posição no espaço social: aferida origem social a partir da profissão e escolaridade dos pais e avós, formação acadêmica, trajetória profissional, prêmios;

- Indicadores de disposições políticas: filiação ou voto em partido político, participação no movimento sanitário, participação em movimentos estudantis, profissionais e sociais, militância e participação em partidos;

- Indicadores de disposições sobre a organização do sistema de saúde: concepção do SUS ${ }^{9}$ e concepções/opiniões sobre as políticas de saúde bucal.

A produção social das políticas de saúde bucal se deu por agentes dos campos burocrático, científico, político. Os agentes desses campos também foram analisados segundo critérios para aferição dos capitais:

- Indicadores de capital burocrático: cargos ocupados;

- Indicadores de capital burocrático universitário: participação na direção de instituições, comissões e órgãos colegiados;

- Indicadores de capital científico: produção acadêmica, pós-graduações, orientações;

- Indicadores de capital político: filiação em partido político, cargos dentro do partido eletivos ou burocráticos que resultem de articulações políticas, cargos ocupados em entidades de classe, movimentos ou associações.

9 Foram utilizadas as diferentes concepções do SUS propostas por Paim (2009): SUS para pobres: reflete a ideia de que a saúde pública é coisa para pobre, concepção de um sistema de proteção social residual, na assistência daqueles que não podem resolver seus problemas no mercado; SUS real: até reconhecem o direito à saúde, mas resignam-se com a situação favorecendo o mercado do setor privado e interesse privado; SUS formal: estabelecido pela Constituição Federal, leis orgânicas, decretos, portarias, resoluções pactos e regulamentos; SUS democrático: desenhado pelo projeto da Reforma Sanitária Brasileira para assegurar o direito à saúde de todos os brasileiros, capaz de influir da saúde e da doença das populações e articulando a saúde de uma reforma social mais ampla. 
Analisaram-se os volumes de capital científico, burocrático e político nos períodos distintos, referentes às quatro políticas analisadas (Quadros 2, 3 e 4). Os capitais burocrático e político se mantiveram com os mesmos critérios nos períodos analisados, entretanto, o capital científico foi modificado no intuito da aproximação das mudanças pelas quais passou o campo científico ao longo dos anos. Os critérios utilizados para a mudança dos critérios na década de 1990 se basearam nas instruções de serviço IS-002/1995 e IS 005/1995 do Conselho Nacional de Desenvolvimento Científico e Tecnológico (CNPq). Já para os anos 2000, foram utilizados os estudos de Barata e Goldbaum (2003), para a Saúde Coletiva, para a produção científica no triênio 2000-2002, e de Santos e colaboradores (2009) sobre o triênio 2004-2006. Para a área de Odontologia, utilizou-se o estudo de Cavalcante e colaboradores (2008) que analisou a produção científica odontológica no triênio 2003-2005 (Quadro 2).

A trajetória profissional dos agentes foi complementada através da consulta ao currículo lattes daqueles entrevistados que possuíam cadastro na plataforma. As entrevistas foram editadas assim como todos os dados foram codificados e analisados conforme os recursos do software NVivo 10.

Foi construída uma linha do tempo com os principais eventos que representam os antecedentes da Política Nacional de Saúde Bucal de 1989, assim como realizou-se uma síntese dos principais fatos analisados no presente trabalho relacionados às políticas de saúde bucal ocorridas em cada período, nos campos burocrático, legislativo, científico, de mídia, movimentos sociais e organizações, nos seus respectivos cenários políticos, adaptada de Barros (2013).

Quanto ao financiamento, analisou-se a Lei de Orçamento Anual (LOA) em cada um dos anos, no período de 1985 a 2010. A análise destas leis expressa o grau de priorização das políticas de saúde bucal no nível federal, assim como o grau de formalização destas no orçamento federal. No intuito de viabilizar a comparabilidade, realizou-se a correção dos valores, eliminando-se o efeito da inflação, através do Índice de Preços ao Consumidor Amplo (IPCA) do Instituto Brasileiro de Geografia e Estatística (IBGE). Todos os valores foram deflacionados para janeiro de 2010, período da última LOA analisada, assim como a conversão das moedas antigas para Real foi realizada através do instrumento de amplo acesso disponibilizado pelo Banco Central do Brasil, a Calculadora do Cidadão. ${ }^{10}$

Este projeto obteve auxílio para a sua realização, através da emissão de passagens aéreas, da compra de equipamentos para coleta de dados, da licença do software de análise de dados, da emissão de passagens aéreas e custeio de hospeda-

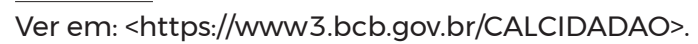


gem na primeira viagem, a partir do termo de outorga JCB 0040/2013 coordenado pela prof ${ }^{\mathrm{a}}$. Sandra Garrido de Barros, assim como pela concessão de hospedagem e alimentação nas demais viagens e transcrições das entrevistas pelo Programa de Pós-graduação em Saúde Coletiva da Universidade Federal da Bahia (PPGSC/ UFBA) pelo Projeto do Observatório de Análise de Políticas com coordenação geral do prof. Jairnilson Silva Paim e do Núcleo de Saúde Bucal da profa. Sônia Cristina Lima Chaves.

O projeto foi submetido ao Conselho de Ética em pesquisa do Instituto de Saúde Coletiva (ISC) da UFBA, tendo sido aprovado sob o $\mathrm{n}^{\circ}$ 18153513.0.0000.5030. Foram observadas as recomendações e normas da Comissão Nacional de Ética em Pesquisa (Conep) a respeito de pesquisas que envolvem seres humanos. Obteve-se o consentimento escrito e informado dos entrevistados em profundidade e o consentimento verbal do entrevistado por telefone. 


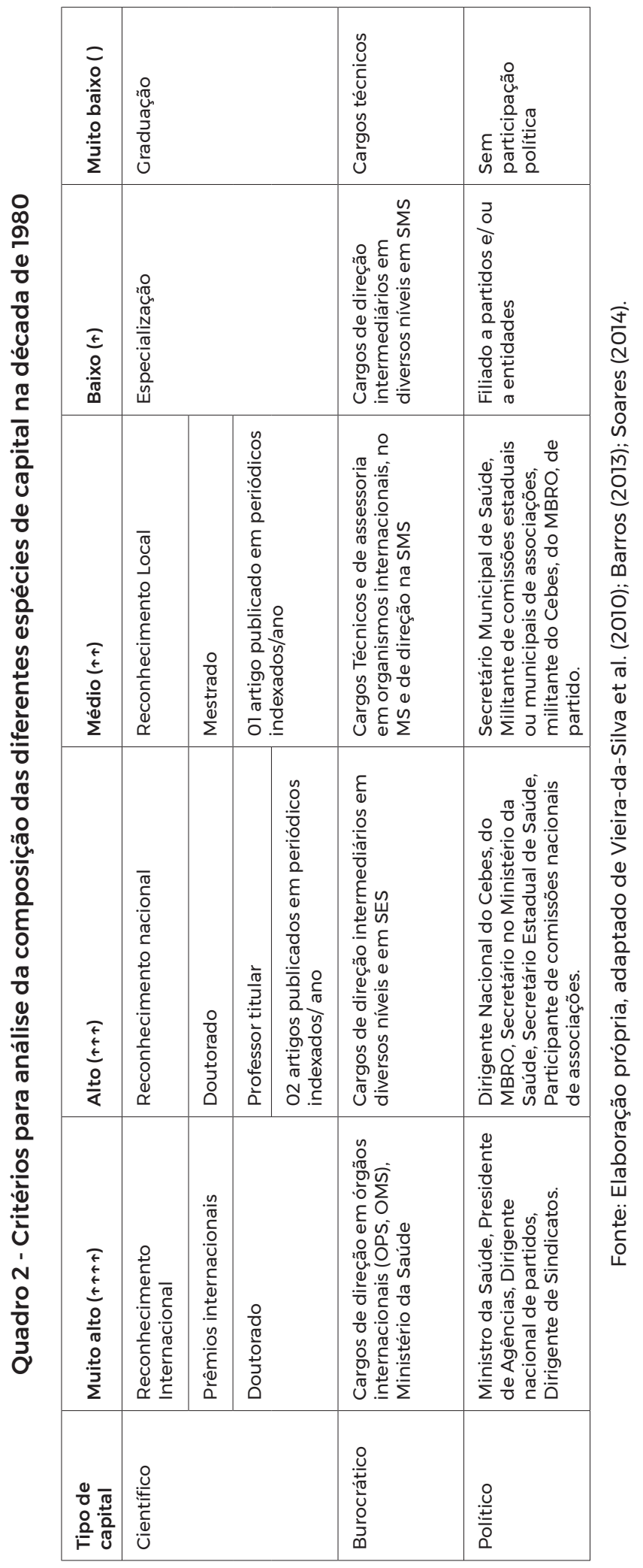

42 / Thais Regis Aranha Rossi 


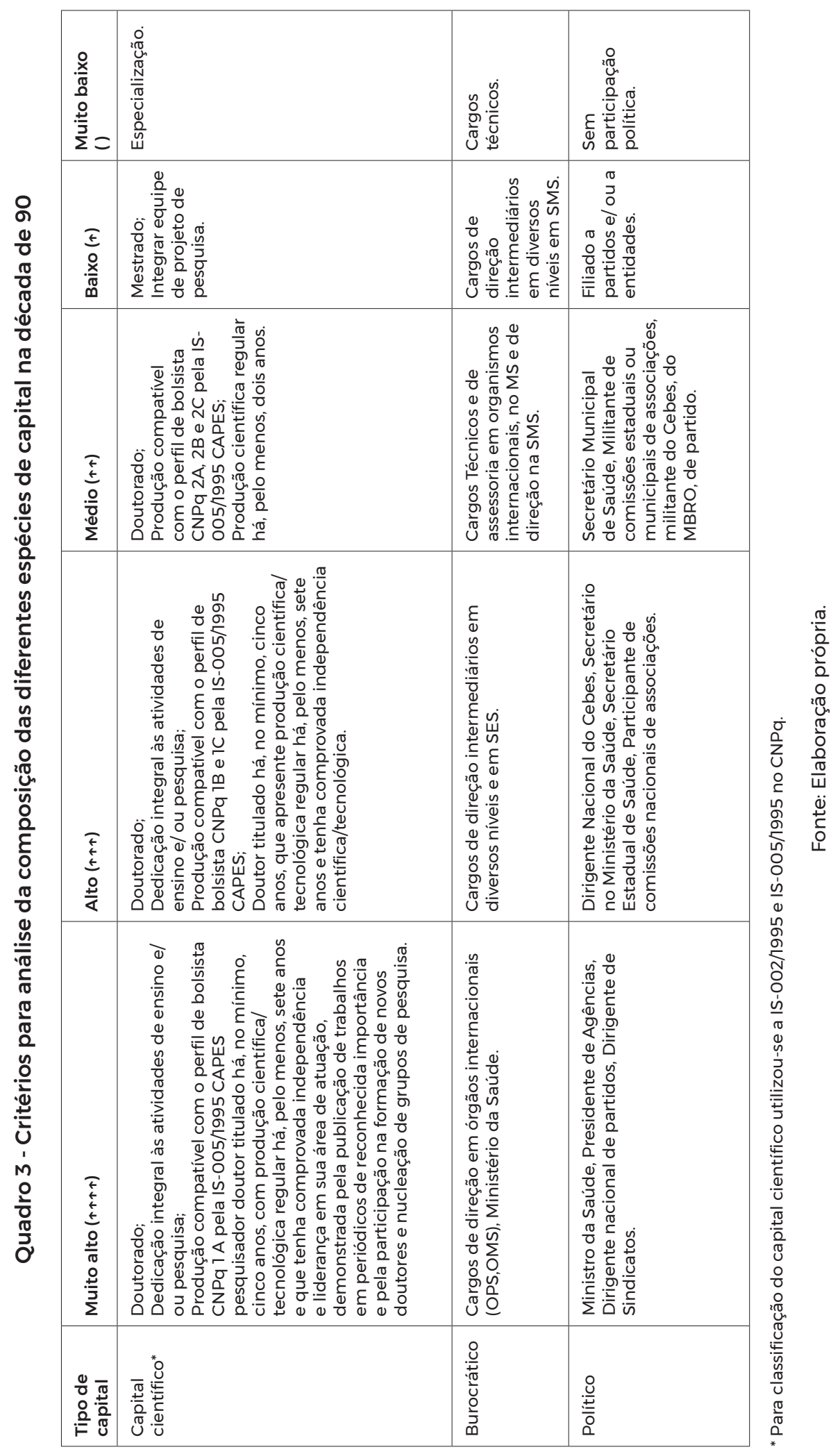




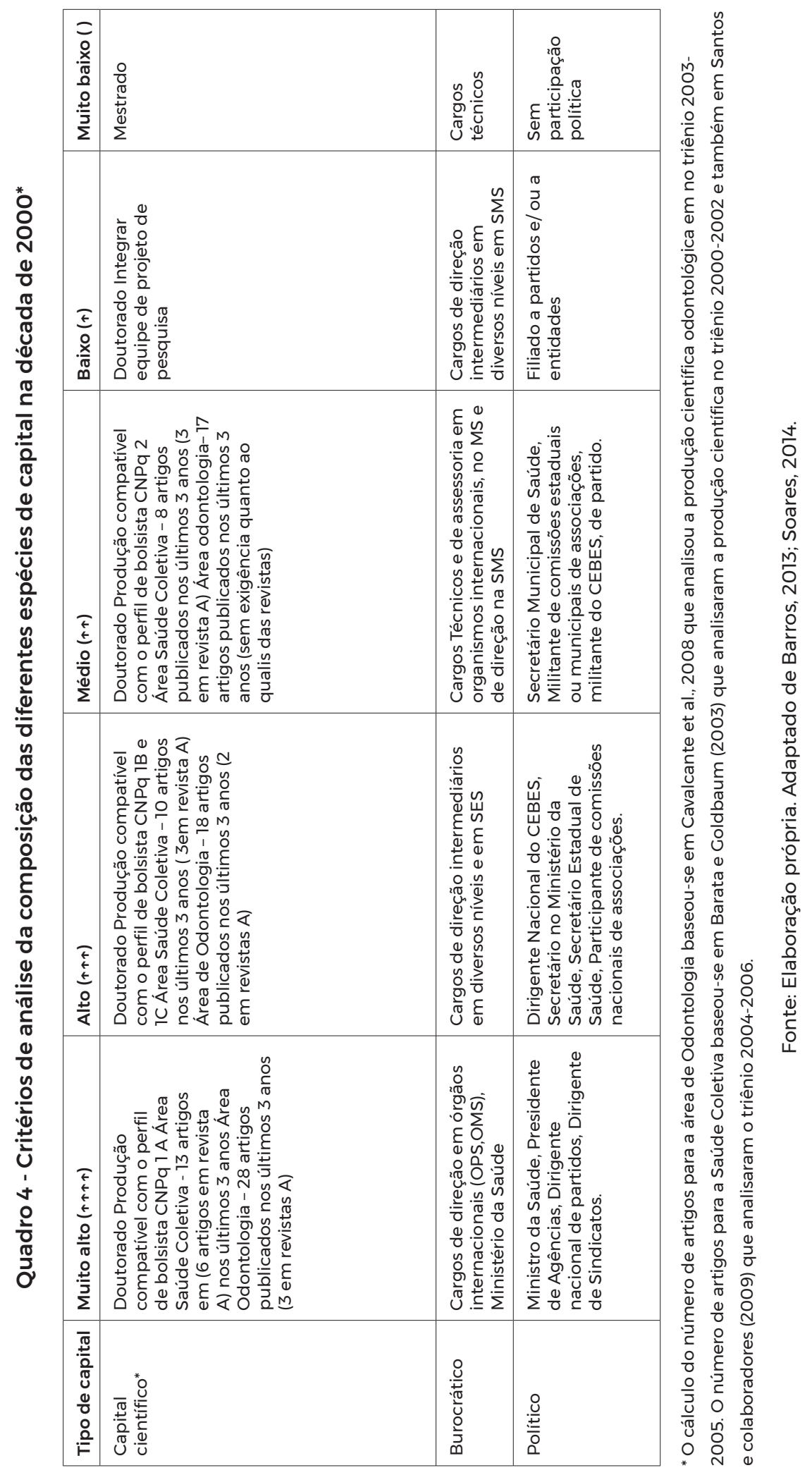

44 / Thais Regis Aranha Rossi 


\section{ANTECEDENTES E QUESTÕES EM DISPUTA RELATIVOS À CONSTRUÇÃO DOS PROBLEMAS BUCAIS ATÉ 1989}

Neste capítulo, pretendemos abordar os antecedentes e questões que estavam em disputa até a década de 1980. No período anterior a 1989, têm sido descritas iniciativas estatais voltadas para alguns problemas bucais, principalmente sob a forma de políticas verticalizadas, desarticuladas entre si e com períodos relativamente curtos de vigência.

A partir de 1922, através da Lei Eloy Chaves, iniciou-se a prestação organizada de serviços de saúde previdenciária através das Caixas de Aposentadorias e Pensões (CAP), com oferta esporádica de serviços odontológicos a alguns segmentos de trabalhadores urbanos. (MOYSÉS, 2014) A partir da criação dos Institutos de Aposentadorias e Pensões (IAP), ocorreu o crescimento das modalidades de compra de serviços do mercado em detrimento da expansão dos serviços próprios. (ZANETTI, 1993) Os odontólogos eram remunerados para tratar dos beneficiários da previdência em seus consultórios, mediante tabela de valores previamente acordada. (PINTO, 1993) Este processo se pautou por orientações administrativas definidas de forma autoritária e centralizada (ZANETTI, 1993) sem o estabelecimento de diretrizes e/ou normas técnicas (VIANNA, 1988) (Figura 1).

No que tange às ações do Ministério da Saúde, na década de 1950, verificou-se a introdução de um modelo misto que envolvia ações tanto curativas como preventivas de inspiração no modelo norte-americano que centrava suas ações em escolares regularmente matriculados, cabendo aos adultos apenas atendimento de urgência. (FSESP, 1971; OPAS, 2006)

O primeiro manual impresso com Normas Técnicas de Odontologia Sanitária foi editado pela Fundação Serviços de Saúde Pública (FSESP), em 1963, no Rio de Janeiro. A política, de cunho nacional, baseada no sistema incremental trazia o atendimento prioritário aos escolares, com possibilidade de considerar alguns casos 


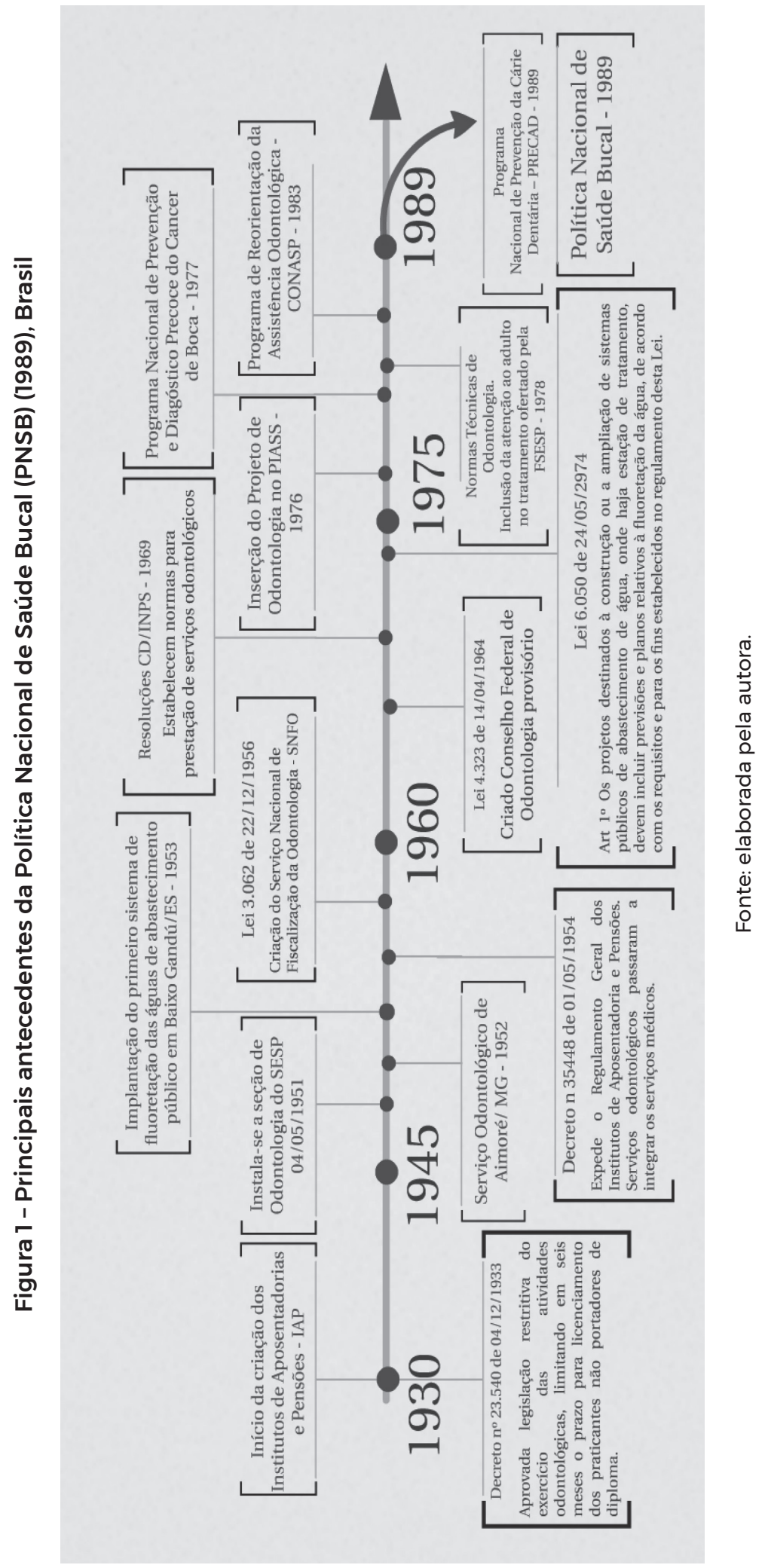

46 / Thais Regis Aranha Rossi 
especiais para atendimento a gestantes e outros, uso de consultórios semiportáteis e utilização de pessoal auxiliar. (FSESP, 1963)

O método preconizado para o exame clínico nas escolas era semelhante aos inquéritos epidemiológicos, fora do consultório, preferencialmente nos pátios. A partir dos exames, se estabeleciam as prioridades dentro do plano incremental de atendimentos a seguir detalhado. O trabalho deveria ser iniciado nas escolas com maior número de matrículas e melhores condições de trabalho. Os resultados da avaliação inicial indicavam as prioridades. Inicialmente, todas as crianças de sete a oito anos e as de seis anos, caso existissem na escola. Nos anos subsequentes, eram escolhidos grupos não selecionados, até que se fizesse necessário o atendimento de manutenção.

No Boletim Diário de Produção e no Relatório Mensal deveriam constar três partes:

- tratamento recuperador a escolares (comparecimentos do paciente ao atendimento, exames dentários, tratamentos completados, ${ }^{11}$ registro apenas dos dentes permanentes, superfícies obturadas em amálgama ou silicato, capeamentos e forramentos e horas trabalhadas);

- tratamento profilático - fluorterapia: (comparecimentos, profilaxias limpezas feitas antes da primeira aplicação de flúor, tratamentos completados - sequência de quatro aplicações de flúor no intervalo máximo de uma semana, horas trabalhadas);

- tratamento radical (comparecimentos dos pacientes que realizaram exodontias, número de elementos extraídos e horas trabalhadas). O manual continha normas para avaliação, treinamento e seleção de pessoal e anexos com os instrumentos a serem preenchidos pelos dentistas da FSESP em serviço, assim como instruções para seu devido preenchimento. Contemplava, também, as normas do treinamento de pessoal.

Quanto ao pessoal auxiliar, um dos conteúdos era a técnica correta de escovação, tendo em vista que estes desenvolviam atividades educativas com pequenos grupos. (FSESP, 1963)

No que diz respeito à Previdência, em 26 de agosto de 1960 (BRASIL, 1960) foi promulgada a Lei Orgânica da Previdência Social (LOPS) que uniformizava o funcionamento e financiamento dos IAP (COHN, 1995), tratava genericamente da

11 Os tratamentos completados deveriam ser realizados em todos os serviços necessários constatados ao exame dentário. (FSESP, 1963) 
prestação de serviços de proteção da saúde. A prestação da assistência odontológica para os beneficiários em geral é incluída na lei, em 1973.

Diretrizes específicas destinadas a orientar a prática odontológica, de acordo com recomendação do Conselho Diretor do Departamento Nacional de Previdência Social foram fixadas em 1969. A assistência previdenciária odontológica proporcionava uma quantidade reduzida de procedimentos, sendo admitida variações de instituto para instituto (IAP) que, depois, foram unificados no INPS, o que trouxe expansão nos serviços e menores discrepâncias no nível nacional, conforme já apontado no trabalho de Vianna (1988) e Pinto (1993). Havia um predomínio de ações curativas, em detrimento de ações de prevenção. O procedimento mais executado eram as extrações dentárias. A cobertura dos serviços odontológicos era baixa dentre a população de segurados.

Um relatório de desempenho da FSESP em 30 anos apontou experiências exitosas quanto à fluoretação das águas de sistemas públicos de abastecimento, com redução de $65 \%$ na incidência de cárie dentária nas populações beneficiadas. (FSESP, 1972) A fluoretação foi implementada em Baixo Guandu, no estado do Espírito Santo, em 1953 e, ao final de 1972, existiam 41 sistemas implantados, beneficiando 733.000 pessoas. (FSESP, 1972) A despeito da avaliação positiva da efetividade de algumas dessas medidas, a cobertura era baixa, tendo em vista que, naquele ano, a população total era de 100 milhões e 800 mil habitantes. Quanto às ações assistenciais, em 1971, a FSESP realizava consultas, restaurações, exodontias de decíduos e permanentes e proteções pulpares para a população de escolares, prioritariamente. Destaca-se que a quantidade de exodontias em outros grupos (não detalhado) superava bastante os números no público de escolares. A maior parte das ações era desenvolvida no Nordeste, quando comparada à produção no Norte e em Minas Gerais. (FSESP, 1971)

Outro marco importante nas políticas de saúde bucal de âmbito nacional foi a Lei $n^{\circ}$ 6.050, de 24 de maio de 1974, que dispunha sobre a inclusão da fluoretação das águas de abastecimento nos projetos destinados à construção ou ampliação de sistemas públicos de abastecimento de água em cidades que já possuíam estação de tratamento. (BRASIL, 1974) Seu projeto de lei, o PL 1415/1968, foi submetido, por Baldacci Filho, do Movimento Democrático Brasileiro (MDB) de São Paulo, em 19 de junho de 1968. Um componente da fluoretação das águas foi incluído no Programa Nacional de Alimentação e Nutrição (Pronan), em 1975, sendo a FSESP responsável pela implementação do projeto em cidades com mais de 50 mil habitantes. (PINTO, 1993) Contudo, estudos que analisaram relatórios de acompanhamento da política apontam que não se alcançou os objetivos esperados, tendo em 
vista que, cinco anos após a assinatura da lei, a FSESP havia executado apenas $8 \%$ (PINTO, 1993) ou 38\% (ZANETTI, 1993) das metas previstas.

Citam-se outras políticas de saúde bucal e normas para prestação do serviço odontológico previdenciário como as Orientações de Serviços (ODS) $\mathrm{n}^{\circ}$ 307.1/1975, ${ }^{12} n^{0} 399.67 / 1975,{ }^{13}$ ODS Inamps $n^{0}$ 89/1985 ${ }^{14}$ e o Programa de Prevenção e Diagnóstico Precoce do Câncer Bucal, em 1976. (VIANNA, 1988) O cirurgião-dentista Benedito Elias Waquim participou da implantação deste Programa.

No início da década de 1980, estudo realizado por Vitor Gomes Pinto, ${ }^{15}$ no âmbito do Instituto de Pesquisas Econômicas Aplicadas (IPEA), que apontava para elevada prevalência de cárie dentária na população brasileira ganhou destaque em jornal de grande circulação no Brasil. O título da matéria chamava a atenção que a cárie era um problema de $95 \%$ dos brasileiros. A publicação, que abordou a formação com enfoque técnico-curativo nas faculdades de Odontologia, apontava soluções para o problema da alta prevalência de cárie como a fluoretação das águas de abastecimento público. Algumas das questões em disputa no espaço da saúde bucal podem ser apreendidas a partir da leitura da matéria. (CARIE..., 1980)

O problema "cárie" era priorizado em detrimento de outras doenças bucais, como a doença periodontal e o câncer de boca. A explicação do problema apontava para a responsabilidade dos profissionais, do ensino e da população. Como estratégias de solução, foram apontadas medidas populacionais como a fluoretação das águas de abastecimento público assim como individuais, com a proposta dos selantes dentários. Segundo a matéria, essas soluções são propostas pelo cirurgião-dentista sanitarista.

Já o ponto de vista da Associação Brasileira de Odontologia (ABO), que defendia a Odontologia liberal, manifestava a preocupação com o custo dos materiais odontológicos, criticava o aumento dos preços dos materiais nobres e/ou caros

$12 \operatorname{AODS~}^{\circ}$ 307.1, de 10 de abril de 1975, estendeu aos adultos a possibilidade de obter tratamento preventivo e conservador, segundo recursos financeiros disponíveis e condições locais. As prioridades para tratamento odontológico eram: (i) urgências odontológicas (odontalgias agudas; hemorragias bucais; traumatologia dento-maxilo-facial, estados infecciosos agudos); (ii) tratamentos cirúrgicos (extrações dentárias; demais tratamentos cirúrgicos dento-maxilo-faciais); (iii) tratamentos conservadores (tratamentos estomatológicos, restaurações plásticas em dentes sem comprometimento pulpar; procedimentos profiláticos). (VIANNA, 1988)

13 A ODS SAM n³99.67/1975 normatizava o atendimento de urgência médica e odontológica. (VIANNA, 1988)

14 A ODS Inamps 89/85 estabelecia as normas para a assistência odontológica para as unidades próprias do Inamps. (VIANNA, 1988)

15 Vitor Gomes Pinto nasceu em Porto Alegre, graduou-se como cirurgião-dentista em 1965, com especialização em Saúde Pública pela Universidade de São Paulo (USP), mestrado e doutorado pela mesma instituição. Foi diretor da Divisão Nacional de Saúde Bucal (DNSB) em 1989. 
como o ouro, a prata e o amálgama, reivindicava a regulação estatal do mercado ao Ministro do Planejamento, Delfim Neto. Frente ao ministro das Comunicações, Said Farhat, demandava uma campanha publicitária que esclarecesse a população sobre a importância da prevenção. Ao Congresso Nacional, solicitava a retirada do projeto do deputado Salvador Julianelli, que regulamentava as profissões da área da saúde, o Projeto de Lei n²726/1980 que acusavam de tentar legislar sobre matéria já disciplinada, interferir na autonomia dos profissionais de saúde, tendo em vista que o profissional médico poderia ser supervisor das práticas de todas as outras profissões de saúde.

No Dossiê do PL n 2726/1980 ${ }^{16}$ constam diversos ofícios de entidades de classe de Psicologia, Fisioterapia, Farmácia, Medicina, universidades federais, sindicatos, assembleias legislativas, câmaras de vereadores contra o Projeto de Lei. Destaca-se que não constam documentos de entidades ou instituições que argumentassem pela Odontologia, entretanto, há uma solicitação do deputado Braga Ramos, dentista de formação, para o envio de todos os projetos relativos à Odontologia para a Comissão de Educação e Cultura, da qual fazia parte. A construção social do problema podia estar ligada à luta pela autonomia do campo odontológico. Ainda em 1980, foi lançado o componente de Odontologia do Programa Nacional de Serviços Básicos de Saúde (Prev-Saúde), que foi anunciado, festivamente, na VII Conferência Nacional de Saúde (CNS) e cujas diretrizes tratavam da responsabilidade pública pelos serviços básicos, pela condução e controle de todo o sistema. Abordava, também, a articulação entre as instituições públicas, a descentralização decisória operacional, a integração das ações de promoção, recuperação e reabilitação, a regionalização, a simplificação de técnicas e meios e eficiência administrativa, sem prejuízo da eficácia social e da participação comunitária. (PAIM, 1984)

O Prev-Saúde era um grande Programa de Extensão de Cobertura (PEC), levando em consideração os 40 milhões de brasileiros sem acesso à saúde e a necessidade de controle de certas epidemias, mas, sobretudo, era uma política racionalizadora de custos. O Prev-Saúde era também a expressão de lutas entre grupos empresariais médicos e o governo brasileiro (PAIM, 1984) e passou por reformulações após sua apresentação inicial.

O subprograma odontológico propunha três níveis de prestação de serviços, utilização de pessoal auxiliar com funções expandidas e unidades de atenção elementar. No nível primário, continha ações de prevenção e prestação de cuidados elementares; no secundário, apoio às atividades de primeiro nível e atendimento a 
escolares do primeiro grau; e no terciário, referência para casos complexos e oferta de próteses “sob lucro zero” (PINTO, 1993), ou seja, custeados pelo usuário. Garrafa (1981) considerou que o Prev-Saúde fora conduzido de forma centralizadora e não participativa, o que não trazia muitas esperanças quanto à mudança do acesso e das condições de saúde bucal da população brasileira.

Havia um ponto de vista crítico, que defendia a fluoretação da água como política prioritária, expresso na posição assumida por Volnei Garrafa, ${ }^{17}$ professor na Universidade de Brasília (UnB) e vice-presidente do Centro Brasileiro de Estudos de Saúde do Distrito Federal (CEBES/DF), no I Congresso Internacional de Odontologia de Curitiba, publicado na revista Saúde em Debate. O autor destacava a criação desenfreada de novos cursos de Odontologia no Brasil, sem reflexo na prática odontológica comunitária, mas com aumento da produção de equipamentos sofisticados e técnicas voltadas para a prática privada da Odontologia de Mercado.

A exemplo das universidades e dos órgãos governamentais, as entidades odontológicas também têm se mantido cegas e surdas diante desta situação, apesar das boas intenções de alguns poucos dirigentes mais lúcidos. O dentista Paulo Narvai, ${ }^{18}$ do CEBES de São Paulo, abordou com muita propriedade este aspecto [...]. Lembrou ele que no IX Congresso Paulista de Odontologia, - um dos três maiores do mundo - realizado em janeiro de 1980, as questões fundamentais foram, mais uma vez somente timidamente levantadas. [...] pela enésima vez, foi discutida uma moção de protesto com relação ao não cumprimento da lei que obriga a fluoretação da água de abastecimento público, ação que diminui em cerca de $60 \%$ a incidência da cárie dental. [...] Nestes congressos [...], são invariavelmente programados inúmeros cursos sobre especialidades, ao lado de um isolado, estéril e repetitivo 'debate' sobre 'odontologia comunitária' ou algo assim, para contrabalançar o peso das consciências individuais de um segmento alienado da média burguesia. (GARRAFA, 1981, p. 52)

Devido à crise econômica e aos altos níveis da inflação, o fluxo de pacientes diminuía bastante nos consultórios privados, o que ocasionava multiplicidade de vínculos mal remunerados e o estabelecimento de convênio com firmas ou entidades. (GARRAFA, 1981) No embate pela defesa dos interesses corporativos, mas

17 Doutor em Odontologia. Presidente da Associação dos Docentes da Universidade de Brasília (ADUnB) e vice-presidente do Cebes/DF. (GARRAFA, 1981)

18 Paulo Capel Narvai era cirurgião-dentista, participante do Cebes de São Paulo. Dentista Chefe da Secção de Odontologia Sanitária. Servidor público (dentista) da SES de São Paulo, em 1986. 
sem uma preocupação muito nítida e concreta com as alternativas ao combate dos problemas de saúde bucal da população brasileira, a Associação Brasileira de Odontologia e o Conselho Federal de Odontologia (CFO) defendiam a Odontologia liberal mesmo ao interior da prestação de serviços previdenciários e exerciam uma posição dominante no campo odontológico. Em muitos momentos, os problemas bucais se tornavam argumentos para a defesa da Odontologia liberal e para assegurar os interesses das entidades de classe. Na ocasião da solenidade de outorga da "Medalha Luis Cesar Panain", medalha de honra ao mérito a dentistas, pelo Conselho Regional de Odontologia de São Paulo (CRO-SP), o presidente do Conselho Federal de Odontologia, Fernando de Souza Lapa, ${ }^{19}$ se dirigiu ao Ministro da Previdência Social Jair Rodrigues, que também era cirurgião-dentista, sobre a importância da criação de um departamento específico de Odontologia no âmbito da previdência, na luta pela autonomia do campo odontológico.

Transformar a Coordenadoria Odontológica do Inamps em Departamento, pois, caso contrário, qualquer plano de saúde bucal estará fadado a falecer antes mesmo do seu nascimento. Não iremos lhe pedir nada. Apenas que entregue as rédeas da Odontologia à própria Odontologia. (LAPA, 1980, p. 7)

Apoiado pelo presidente da Associação Brasileira de Odontologia (ABO), Paulo Frenkel, ${ }^{20}$ e pelo presidente da Federação Nacional dos Odontologistas

19 Fernando de Souza Lapa era "Especialista em Cirurgia e Traumatologia Buco - Maxilo Facial e em Ortodontia, recebeu o tìtulo de Sócio-BenemĖrito do Colégio Brasileiro de CTBMF. Foi responsável pelo setor de Ortodontia e Cirurgia Buco-Maxilo Facial da disciplina de Cirurgia Plástica e Queimaduras do Hospital das Clínicas da Faculdade de Medicina da USP, desde 1963. Doutor em ciências pela Faculdade de Medicina da Universidade de S „o Paulo, aprovado com nota máxima. Foi o primeiro Cirurgião-Dentista a defender tese de Doutoramento em Cadeira de Cirurgia da Faculdade de Medicina da USP. Era doutor em Odontologia pela PUC do Rio Grande do Sul, Livre Docente em Cirurgia e Traumatologia Buco-Maxilo Facial da mesma faculdade, professor extranumerário do curso regular de Medicina da USP, desde 1961, professor titular da especialidade na Faculdade de Odontologia de Santo Amaro (OSEC) e da Faculdade de Odontologia da Zona Leste e membro de diversas Comissões Examinadoras de Concursos para Livre Docíncia. Foi membro de inúmeras Associaçõıes como a Federation Dentarie Internacional, a British Association for Maxilo Facial Surgery e a Sociedade Argentina de Cirurgia y Traumatologia Buco Maxilo-Facial. Seu enorme currìculo compunha-se de mais de 400 tìtulos. [...] Foi o segundo presidente do Conselho Regional de Odontologia de $S_{n}$ o Paulo, tendo construído e ampliado a sede da avenida Paulista e dirigido a entidade de 1972 a 1976 [...]. No CFO, deu ênfase às especialidades, criando concursos para habilitação de profissionais, através de bancas de professores eméritos [...]. Reformou e informatizou a sede do Rio de Janeiro". (FALECIMENTO..., 2004, p. 11)

20 Paulo Frenkel era cirurgião-dentista, presidiu a ABO. Na sua gestão, em 1981, organizou o congresso da FDI World Dental Federation, no Rio de Janeiro. Atuou na FNO. Foi $2^{\circ}$ Secretário da Confederação Nacional das Profissões Liberais de 1972 a 1975. 
(FNO), Joaquim Arsênio Benedicto Ottoni Junior, ${ }^{21}$ Lapa citou a iniciativa do referido Ministério em montar uma comissão interministerial para estudar os problemas de saúde bucal e montar um plano de assistência à saúde. Entretanto, defendia a reivindicação das entidades de classe que sua participação neste movimento fosse assegurada, assim como, maior autonomia no setor de Odontologia da Previdência.

O presidente do CFO justificava que não era apenas o Brasil que apresentava um quadro alarmante de falta de acesso aos serviços odontológicos, recusando a suposição de que os cirurgiões-dentistas seriam os únicos responsáveis pela situação. Também nos Estados Unidos, a situação não conseguia ser contornada. Adicionava o interesse das entidades de classe odontológica por "fazer alguma coisa em benefício da comunidade brasileira” através da Previdência Social. Novamente, é possível constatar aspectos da construção da doença cárie como um problema social.

A posição defendida pelo presidente do CFO reivindicava para a Odontologia o mesmo status da Medicina caracterizando-as como “irmãs-gêmeas", mas também defendia a conquista de espaço profissional e autonomia do campo odontológico, ao passo em que afirmava que a Odontologia necessitava ser independente, autônoma e separada, lutando pela equivalência à Medicina hegemônica, e criticava a formação de pessoal auxiliar e o aumento indiscriminado de profissionais.

Ele opunha também as associações profissionais à tecnocracia, diferenciando, assim, o ponto de vista legitimo da Odontologia e das suas associações, daquele da "tecnocracia" e dos planos de gabinete. Esta oposição pode ser caracterizada como o enfrentamento entre o ponto de vista liberal e o ponto de vista do campo burocrático dos sanitaristas. O financiamento das ações para os serviços odontológicos se concentrava na Previdência Social, direcionado aos trabalhadores e seus dependentes.

Em entrevista, Vitor Gomes Pinto ${ }^{22}$ conta que os dentistas se dirigiam à Previdência Social como "a toda poderosa", pois o financiamento das ações para saúde bucal pelo Ministério da Saúde, no início da década de 1980, era praticamente inexistente. No ano seguinte, 1981, as pressões por parte das entidades de classe continuaram sobre o ministro da Previdência Social, Jair Soares, por maior autonomia para o setor odontológico dentro da previdência. A plenária final do V Congresso Internacional de Odontologia, realizado no Rio de Janeiro, no mesmo ano,

21 Joaquim Arsênio Benedicto Ottoni Júnior foi presidente da Federação Nacional dos Odontologistas (FNO) e conselheiro fiscal da Confederação Nacional das Profissões Liberais de 1972 a 1975.

Entrevista concedida à autora, Brasília, em 21 ago. 2014. 
apontou que os dentifrícios comercializados no Brasil não continham flúor e desta forma, não exerciam seu papel na prevenção das cáries, servindo apenas para facilitar a escovação e melhorar o hálito. (CIRURGIÕES-DENTISTAS..., 1981) Ademais, criticavam a efemeridade do Prev-Saúde, criado em 1980, propunham uma Odontologia Social ${ }^{23}$ e criticavam que a oferta de serviços odontológicos consistia nesse programa e não em um departamento. Com forte domínio da Odontologia de mercado, criticavam também o monopólio da indústria internacional na produção de insumos odontológicos e sugeriam a importância do investimento na indústria nacional. (CIRURGIÕES-DENTISTAS..., 1981)

No mesmo ano, ocorreu o I Encontro Internacional de Odontologia, em Curitiba no qual Volnei Garrafa mostrava que o Brasil possuía o mesmo número de dentistas dos Estados Unidos da América, entretanto, com distribuição muito desigual. Criticava também a formação em Odontologia e a prestação de serviços públicos e privados.

A Odontologia, no Brasil, é ineficaz e ineficiente; descoordenada; os seus recursos humanos são mal distribuídos, pois há uma enorme concentração de dentistas nas grandes cidades; a cobertura de assistência que ela oferece é muito baixa; está numa faixa de alta complexidade e sofisticação; desenvolve exclusivamente um enfoque curativo, sem nenhuma preocupação preventiva; seu caráter é mercantilista e monopolista. (BRASIL..., 1981, p. 26)

Nessa mesma publicação, o autor apontava para a omissão enquanto a política de saúde bucal ${ }^{24}$ que "[...] encarasse a questão odontológica dentro da sua devida importância” (BRASIL..., 1981, p. 26), ratificada por outra publicação no jornal que tratava do ponto de vista dos usuários de consultórios privados, apontando que, devido à crise, o paciente passava a frequentar consultórios populares. (DENTISTAS..., 1981) Esse ponto de vista formulado por Volnei Garrafa, cuja trajetória dominante havia sido no interior do espaço da Saúde Coletiva em formação, é semelhante à crítica realizada por muitos sanitaristas ao Sistema de Saúde vigente à época.

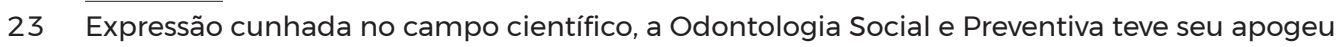
na ditadura militar, no período entre 1968 e 1978, e seu declínio na década de 1980. Tem como base as formulações da Odontologia Sanitária. (NARVAI, 2006)

24 Cumpre ressaltar que, segundo o conceito de política de saúde adotado no presente estudo, sempre há uma política de saúde, sendo traduzida em ação ou omissão do Estado. Neste caso, a política de saúde bucal seria a omissão. 
O presidente do Conselho Regional de Odontologia de São Paulo, Wilson Garoni, ratificava que “[...] o atendimento dentário não está ao alcance da população". (DENTISTAS..., 1981c) A grande prevalência de cárie entre crianças de 6 a 14 anos foi amplamente discutida, assim como a inexistência de um programa de prevenção dedicado a esta faixa etária. Tratava, ainda, das insuficiências dos Ministérios da Saúde e da Previdência chegando à crítica moral.

O Ministério da Saúde não tinha nenhum setor, nenhum departamento, nenhuma pessoa para atender telefone, no que se refere ao setor odontológico. Já a Coordenação odontológica do Inamps, que desenvolve um trabalhão do tipo tapa buraco, de caráter mutilador, é dirigida por pessoas incompetentes e alienadas. (BRASIL..., 1981)

A simplificação do atendimento, que originou a corrente teórica da Odontologia Simplificada, ${ }^{25}$ era apontada como uma das alternativas para solucionar os problemas crescentes que os dentistas vinham enfrentando de mercado de trabalho. A parcela de $5 \%$ da população que custeava seu tratamento através de desembolso direto estava muito saturada. (ODONTOLOGIA..., 1981)

O precário programa de fluoretação das águas também foi alvo de críticas. Em outro evento, em 1982, no IV Encontro Municipal de Odontologia Comunitária, Vitor Gomes Pinto também criticava a ausência de uma política para enfrentar os problemas de saúde bucal da população brasileira. (ODONTOLOGIA..., 1981)

Pinto também defendeu a divisão de tarefas no processo de trabalho em saúde bucal com pessoal auxiliar, em outro evento científico, o $1^{\circ}$ Congresso de Odontologia do Vale do Parnaíba. Nos Anais da VII Conferência Nacional de Saúde, em 1980, já constava a preparação de recursos humanos de nível auxiliar e técnico, além de uma recomendação, em caráter urgente, acerca da formação de um "técnico dental operador”. Ressalta-se que a introdução do pessoal auxiliar no Brasil vem sendo experimentada desde 1950, com os Serviços Especiais de Saúde Pública (SESP). (FAQUIM; CARNUT, 2012) A partir da década de 1980, o processo de muitas disputas ao interior do campo odontológico seguiu pelas atividades a serem desempenhadas no processo de trabalho, destacando-se as tomadas de posição das associações de classe que assumiam lugar mais conservadora defendendo que o técnico poderia assumir o lugar do Cirurgião-Dentista (CD) ou que um CD ficaria

25 A Odontologia Simplificada surge no discurso odontológico nos anos 1970. A expressão vinha sendo utilizada na América Latina e era utilizada para tratar da padronização, diminuição dos passos, eliminação do supérfluo, tornando mais simples e barata a Odontologia, sem alterara a qualidade. Assim, tornava viável os Programas de Extensão de Cobertura. (NARVAl, 1994) 
responsável por supervisionar uma quantidade muito grande de pessoal auxiliar, o que impactaria no mercado de trabalho para ele.

\section{Plano de reorientação da assistência odontológica (Praod) e ações do Inamps}

Em 1982, foi lançado o "pacote da previdência” através de um pronunciamento do presidente da República João Figueiredo, em rede nacional de televisão. Este "pacote" tratava do reordenamento dos serviços de saúde, da substituição do pagamento por ato pelo pagamento por tratamento e da expansão dos convênios com a medicina de grupo. (PAIM, 1984) Nesse momento de crise da Previdência, foi criado o Conselho Consultivo de Administração de Saúde Previdenciária (Conasp), através do Decreto $n^{\circ} 86.329$, de 2 de setembro de 1981. Dentro do plano do Conasp, havia a proposta do Programa de Ações Integradas de Saúde (AIS) que propiciava o convênio de municípios com o Inamps. (PIRES, 2004)

O Plano de Reorientação da Assistência Odontológica (Praod) foi editado em 1983, pelo Ministério da Previdência e Assistência Social (MPAS), na gestão no ministro Hélio Beltrão que sucedeu a de Jair Soares. Este documento foi elaborado por um grupo de cirurgiões-dentistas que integravam a Comissão de Especialistas em Odontologia do Conasp, responsável por "apreciar e apresentar princípios e questões fundamentais da assistência odontológica em nosso meio, e como consequência, de seu estudo crítico das propostas e dos relatórios então apreciados [...]”. (BRASIL, 1983) (Figura 2).

A Comissão de Especialistas foi instituída pela Portaria Inamps/PR n ${ }^{\circ} 855 / 82$, de 24 de novembro de 1982, sendo constituída por: Paulo da Silva Freire, ${ }^{26}$ coordenador da assistência odontológica do Instituto Nacional de Assistência Médica da Previdência Social (Inamps); Olympio Faissol Pinto, odontólogo; Alfredo Reis Viegas, professor da USP; Eugênio Vilaça Mendes, professor da Universidade de Belo Horizonte; Edrizio Barbosa Pinto, da Associação Brasileira de Ensino Odontológico; Solón Magalhães Vianna, odontólogo; Waldir Viana das Neves, da FSESP; Mercio de Azevedo Ferreira, do Ministério da Saúde; Paulo Monteiro Freitas, da Federação Nacional dos Odontologistas; Manoel Tompson de Araújo, da Associação Brasileira de Odontologia; José Roberto Pontes, do Sindicato dos Odontologistas

26 Paulo da Silva Freire, cirurgião-dentista, integrou a FSESP. Professor da Universidade Federal Fluminense (UFF), foi diretor da seção de Odontologia no Inamps. Integrou a diretoria da Associação Brasileira de Ensino Odontológico de 1971 a 1974. 
do Rio de Janeiro; Fernando de Souza, do Conselho Federal de Odontologia; Sérgio Pereira, da Secretaria de Educação do Distrito Federal; José Dilson Vasconcelos de Menezes, do Inamps/CE; e Vitor Gomes Pinto, do IPEA. Um dos participantes da comissão retrata o caráter das mudanças ocorridas no âmbito da Previdência e não apenas na Odontologia e fala sobre o convite para Paulo Freire se tornar o coordenador de odontologia do Inamps.

[...] No tempo do Aloysio, foi nessa época que o Inamps no movimento de mudança geral. O grupo do Inamps que era diferente do grupo da ENSP, Sergio Arouca e etc. O grupo do Inamps, era esse grupo do Eleutério Rodriguez Neto, do tempo do Aloysio Sales que era um médico famoso [...] Isso gerou aquela proposta de mudança da previdência social da saúde. E aí eu participei desse grupo onde estava o Paulo [da Silva] Freire, quando o Inamps formula essa proposta de saúde bucal. [...] Nesse tempo do Paulo Freire teve esse movimento que não foi só da odontologia foi um movimento de reforma da previdência social na saúde. [...] tem uma série de medidas que são editadas com modificações de procedimentos com o perfil do serviço. Lembro do Alfredo Reis Viegas que você tem aí também. Ele éfundamental. (Entrevisado 14, dentista, consultor)

O Entrevistado 14 fez uma diferenciação entre os grupos do Inamps e da Escola Nacional de Saúde Pública Sérgio Arouca (ENSP) que se situavam em equivalência com o grupo de fundadores da Saúde Coletiva no Brasil, sendo adotada como uma reforma ampla aquela desenvolvida pelo grupo no âmbito do Plano Conasp, tendo sido considerada enquanto medida racionalizadora por Paim (2008). A mídia impressa noticiou o lançamento do Praod como o plano que modificaria a assistência odontológica no Brasil, contudo, este não trazia nenhuma novidade em seu conteúdo. O plano era retratado como a expressão das reivindicações feitas pelos sanitaristas da época. (PRONTO..., 1983)

O documento incorporava, principalmente, os pontos de vista da burocracia através dos sanitaristas do IPEA. Ademais, incorporava o ponto de vista defendido por Alfredo Reis Viegas da Faculdade de Saúde Pública da USP, mas também da Odontologia de liberal através das entidades de classe como CFO e ABO. Autores apontam que o modelo da assistência odontológica previdenciária sintetizou o modelo da Odontologia de mercado ${ }^{27}$ inserido no aparelho estatal. Outro ponto de

27 A Odontologia de mercado deriva da Odontologia liberal e se baseia na assistência odontológica ao indivíduo doente, realizada pelo cirurgião-dentista no âmbito do consultório. (NARVAI, 1994) Predomina no setor privado, mas, também, no serviço público, através de sua essência na base biológica e individual, sendo orgânico ao modo de produção capitalista que transforma os cuidados de saúde em mercadoria. (NARVAl, 2006) 
destaque foi a dificuldade enfrentada pela comissão de especialistas em obter dados para subsidiar o plano. (NARVAI; FRAZÃO, 2008a, 2008b; PRONTO..., 1983)

Figura 2 - Capa do documento Plano de Reorientação da Assistência Odontológica (Praod)/Ministério da Previdência e Assistência Social ${ }^{28}$

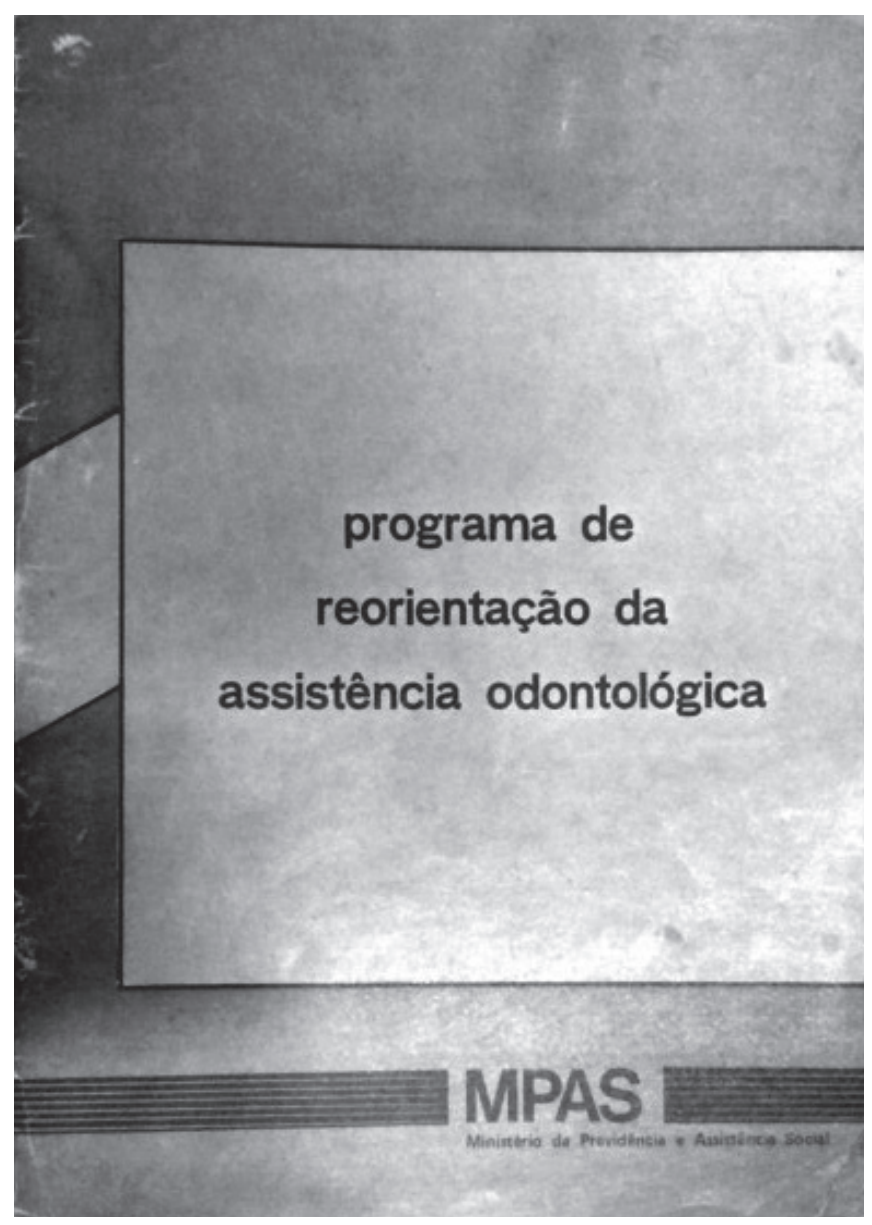

Fonte: Brasil (1983).

Na apresentação assinada pelo presidente do Conasp, Aloysio de Sales Fonseca, o documento é caracterizado como um programa em que "dominam as ações e políticas administrativas e técnicas, todas iluminadas pelos critérios de coparticipação, integração, regionalização, hierarquização e descentralização, de modo a assegurar maior cobertura e eficiência da Instituição e racionalização das despesas”. (BRASIL, 1983) 
O Praod tinha como objetivos/pressupostos:

- estender a cobertura dos serviços odontológicos básicos ${ }^{29}$ a toda a população;

- reduzir a incidência das doenças bucais de maior expressão epidemiológica através da aplicação racional de métodos de massa e de atenção individual aos grupos prioritários;

- aumentar a produtividade do sistema, buscando uma melhor relação custo/benefício;

- integrar ao sistema os órgãos públicos federais, estaduais e municipais assim como as instituições e entidades de ensino beneficentes e organizações sindicais e patronais, proporcionando uma descentralização das atividades e maiores possibilidades de atendimento. (BRASIL, 1983)

Essas diretrizes foram em parte incorporadas ao Sistema Único de Saúde. Seus princípios norteadores eram:

- integração das ações de prevenção, recuperação e de educação em saúde;

- reorientação do sistema, privilegiando a ampliação das ações básicas de saúde;

- integração dos organismos federais de prestação direta de serviços de saúde com os de âmbito estadual e municipal, de ensino, instituições pias e beneficentes e organizações sindicais e patronais;

- pleno aproveitamento da capacidade ociosa e racionalização de procedimentos técnico-administrativos;

- efetiva participação comunitária nos programas de saúde da boca;

- definição clara do papel do setor privado vinculado a programas oficiais;

- planejamento e ações de saúde segundo os princípios de regionalização e hierarquização dos serviços e de racionalização e simplificação dos métodos de trabalho. (BRASIL, 1983)

A comissão retrata a importância do flúor no combate à doença bucal mais prevalente à época, a cárie dental, dos equipamentos simplificados e da utilização de pessoal auxiliar. Alguns princípios gerais eram semelhantes aos do Prev-Saúde, Interiorização das Ações de Saúde e Saneamento (Piass), mas em caráter ainda restrito. 
como a regionalização do sistema e a hierarquização dos serviços. (VIANNA, 1988) Algumas políticas públicas foram abordadas, como os primeiros projetos de utilização de equipamentos simplificados e de pessoal auxiliar em Aimorés, Minas Gerais, em 1952, pela FSESP, direcionado à população entendida como mais vulnerável, na faixa etária de 6 a 12 anos, o tratamento incremental, a experiência pioneira do processo de fluoretação das águas em Baixo Gandú, Espírito Santo, em 1953, e os programas de atenção ao escolar.

O Praod retrata uma ausência de valorização histórica da saúde bucal e o baixo financiamento para as ações. Compara o Brasil com outros países quanto à prevalência da cárie dentária apontando para a difícil situação que o país enfrentava com média de dentes cariados, perdidos e obturados na população examinada com índice CPO-D de 7,2. Países como a Tanzânia, Libéria tinham CPO-D de 0,6, na Inglaterra era 3,1 e no México era 5,2. (BRASIL, 1983)

Assim, a cárie dental era caraterizada, nos anos 1980, como principal problema de saúde bucal da população brasileira, seguida pela doença periodontal, as deformidades dento-faciais, lábio leporino e fenda palatina e câncer de boca. Não existia um inquérito epidemiológico oficial específico de saúde bucal no Brasil, em 1983, e os dados oriundos de pesquisas locais ou estaduais realizadas por outros autores utilizados foram trabalhados por Vitor Gomes Pinto, integrante da comissão, no âmbito do IPEA, em 1983, oriundos principalmente de São Paulo, mas também Bahia, Espírito Santo, Distrito Federal, Minas Gerais, Paraíba, Pernambuco, Rio Grande do Sul e Rio Grande do Norte. O Plano já indicava um grande aumento do CPO-D no decorrer das faixas etárias com um aumento exponencial do componente perdido enquanto uma prática predominante no exercício da Odontologia. Outro quadro que tinha como fonte estudos do prof. Alfredo Reis Viegas sinalizava uma demanda por tratamento odontológico de milhões de pessoas, com base na população brasileira de 1980.

Caracterizando o modelo da assistência odontológica no Brasil, o Inamps, principal instituição pública prestadora de serviços odontológicos no país, era responsável por $58,5 \%$ de todos os gastos públicos efetuados em 1981. (BRASIL, 1983) Neste ano, a saúde bucal representava 3,19\% dos gastos públicos em saúde (BRASIL, 1983), entretanto, o setor público contribuiu com apenas $18,2 \%$ dos gastos em saúde bucal, cabendo ao setor privado a maioria dos dispêndios pessoais e institucionais. (BRASIL, 1983) A necessidade do investimento em prevenção era justificada pelo volumoso montante estimado para o tratamento curativo no período, sendo a atividade preventiva urgente para a redução dos gastos assistenciais. Dentre as modalidades de prestação dos serviços odontológicos pelo Inamps, as 
principais, segundo o número de consultas e os gastos efetuados, eram a modalidade de serviços próprios e de credenciamento de pessoas físicas.

Em 1982, Paulo da Silva Freire, dentista que fez parte da FSESP, assumiu o cargo de Coordenador da Assistência Odontológica do Inamps, através da Portaria PT/PR 791, de 10 de setembro de 1982. Assim, tal como a “[...] exportação do Coordenador de Odontologia da FSesp” para o Inamps, "as soluções gerenciais para as deficiências sanitário-bucal começaram a tomar orientações sespianas”. (ZANETTI, 1993, p. 70)

A participação de entidades na redação do Praod é controversa. Os entrevistados 12 e 26 do programa afirmam ter contado com a participação de representantes de associações. Já segundo o depoimento do Entrevistado 4, o documento havia sido construído em caráter sigiloso e editado verticalmente sem a participação de órgãos da gestão, como as coordenações estaduais.

O Praod foi escrito no IPEA e considerado como contendo "os avanços possíveis no período", tendo em conta "o que podia ser compreendido pela coordenação de odontologia do Inamps” e o estágio das discussões no Sistema de Saúde. (PINTO, 1983, p. 112) Devido a influência dos autores, o documento traz características da saúde pública vigente no período, mesmo sendo uma publicação da previdência. Este documento apontava para a limitação do Inamps em atender às demandas da população brasileira e propunha o atendimento a grupos vulneráveis. A necessidade das ações de prevenção era trazida como um imperativo de parceria com outros ministérios, já que o Ministério da Saúde, à época, não era responsável pelas ações assistenciais, cabendo ao Ministério da Previdência. Os cidadãos que não trabalhavam, não tinham acesso à saúde. Este texto é tido como de grande avanço para a época por autores, entretanto, não há análises mais detalhadas sobre ele.

Ainda em 1983, o Inamps, através do seu coordenador específico de Odontologia, Paulo Freire, celebrou um convênio de experiência docente-assistencial com a Pontifícia Universidade Católica de Minas Gerais (PUC-Minas). Como Paulo Freire havia sido da FSESP e Mário Chaves foi um apoiador deste projeto, a Universidade contou com recurso do Inamps. Através deste projeto propõe-se um novo modelo de Odontologia simplificada, inspirado no Programa Integrado de Saúde do Escolar (PISE), elaborado por Sérgio Pereira, no Distrito Federal. A experiência serviu de modelo para muitas faculdades de Odontologia que conseguiram reduzir a quantidade de extrações em comparação ao praticado nos serviços do Inamps, segundo o Entrevistado 14. O Departamento de Odontologia da PUC-Minas desenvolveu importante experiência de reorientação do ensino odontológico. Defendia-se o desenvolvimento da Odontologia Integral, mas, na prática, reproduzia-se as 
propostas da Odontologia sanitária/social e comunitária/simplificada. (NARVAI, 1994)

No ano seguinte, 1984, o problema cárie permanecia figurando como o principal, na mídia impressa, que continuava a trazer matérias de eventos científicos e pautas acerca do enorme número de desdentados no Brasil, aproximadamente 10 milhões de pessoas, em 1984. (O BRASIL..., 1984) Acerca da doença cárie, Entrevistado 1 ressalta:

[...] o flúor estava começando, então a cárie avançava. Você fazia uma 'O' [restauração oclusal], e em seguida ela [aumentava] e pegava vestibular. Quer dizer, aquilo era um negócio avassalador. Quando você via, o dente estava comprometido [...] A cárie era o fenômeno biológico mais avassalador.

Em 1984, foi assinado um convênio entre os Ministérios da Previdência Social, Saúde e Educação a fim de incluir a assistência odontológica no plano de integração das ações básicas de saúde do Conasp. O programa foi considerado como a "redenção da saúde oral para o povo brasileiro", pelo ministro da Educação, que solicitou o atendimento a escolares também no período de férias. (O BRASIL..., 1984) O Inamps também investiu em um Programa de Selantes Oclusais, entretanto, não obteve muito sucesso, apesar do investimento em grandes quantidades de material. (PINTO, 1993)

\section{Políticas de Saúde Bucal no âmbito do Instituto de Pesquisas Econômicas Aplicadas (IPEA)}

Na saúde bucal, as principais políticas conduzidas pelo Instituto de Pesquisas Econômicas Aplicadas (IPEA) foram a fluoretação das águas de abastecimento público, que ficou sob responsabilidade da FSESP e monitorada pelo IPEA, com financiamento do Banco Nacional da Habitação (BNH), e a saúde do escolar, que foi alocada no Ministério da Educação, também monitorada pelo Instituto. A fonte de financiamento destas ações foi o Fundo de Apoio ao Desenvolvimento Social (Finsocial).

A proposta para a saúde bucal, no Programa Nacional financiado pelo Finsocial, previa pequena extensão de cobertura e estimava beneficiar até 30 milhões de pessoas que, somadas aos 25 milhões que já estavam protegidas, atingiria $46 \%$ da população brasileira no início da década de 1980. (VIANNA; PINTO, 1983) Este projeto adotava metas menos pretensiosas que o anterior programa de fluoretação, em parceria Instituto Nacional de Alimentação e Nutrição (INAN) e FSESP, e bus- 
cava reativar a operacionalização dos sistemas paralisados e estender a fluoretação em 35 cidades. (VIANNA, 1988) As estratégias de implantação envolviam os recursos oriundos do Finsocial que, mediante convênio com o BNH, teria os recursos repassados com o Banco Nacional de Desenvolvimento Econômico e Social (BNDES). No acompanhamento do projeto, estavam a Secretaria de Planejamento (IPEA/BNDES), o BNDES e o Ministério da Saúde, através do GT-Odonto ${ }^{30}$. Ademais, $5 \%$ do valor do Programa se destinava ao GT-Odonto, Comitê de Saneamento do Ministério da Saúde, FSESP e Secretarias de Saúde, para estudos epidemiológicos, controle da água e pesquisas de métodos alternativos de prevenção da cárie dental com recursos próprios do Ministério da Saúde. (VIANNA; PINTO, 1983)

Quanto ao programa de saúde escolar, foram estabelecidas como ações básicas: a inscrição do aluno - primeiro contato do indivíduo com o responsável pelas ações de saúde na escola para elaboração da sua ficha de saúde, com anotações de caráter geral; vigilância epidemiológica - manter a vigilância sobre a saúde das crianças e tomar as medidas adequadas, principalmente nos casos de doenças transmissíveis; visitação domiciliar; primeiro atendimento - problemas de saúde surgidos na escola, prestação de primeiros socorros e curativos em acidentes; identificação de problemas mais comuns - estado geral, pele e couro cabeludo, boca, olhos, ouvidos, comportamento; educação em saúde e controle das condições de saneamento Especificamente na saúde bucal, o Programa propunha priorização do escolar do $1^{\circ}$ grau e a utilização do sistema incremental, tendo como alicerces a formação de pessoal de nível superior, técnico e elementar, além da Odontologia Simplificada, que propunha o controle sobre o uso de procedimentos sofisticados. (VIANNA; PIOLA; PINTO, 1983) O Programa envolvia a participação direta do Ministério da Educação e Cultura (MEC), da Secretaria de Planejamento e Assuntos Econômicos (Seplan), BNDES e IPEA, MS e MPAS, conforme citado anteriormente.

Diante do recurso citado, que foi alocado no Ministério da Saúde, o órgão lança uma proposta de utilização de recursos envolvendo levantamento epidemiológico sobre saúde bucal, pesquisa sobre métodos alternativos de fluoretação, implementação da fluoretação da água em localidades do Nordeste, atividades de coordenação e apoio a nível central, educação em saúde e Vigilância Sanitária. (VIANNA, 1988) As ações de Vigilância Sanitária foram estruturadas em cada estado, com exceção de Minas Gerais, nos Grupos Especiais de Controle da Fluoretação (Gecof). Já as ações de educação em saúde ficaram a cargo da Divisão Nacional de Educação Sanitária e a Divisão Nacional de Ecologia Humana e Saúde Ambiental 
do Ministério da Saúde ficou responsável pelo controle dos níveis de fluoretação das águas para o consumo humano. (VIANNA, 1988) As pesquisas trataram sobre métodos alternativos em estações de tratamento de água e sobre a viabilidade da fluoretação do sal no Brasil. ${ }^{31}$ (ZANETTI, 1993)

Benedito Elias Waquim ${ }^{32}$ que participou do GT-Odonto comentou as ações desenvolvidas no âmbito desses programas:

Nós conseguimos um recurso do Banco Nacional de Desenvolvimento Social, através da Caixa Econômica, e a partir daí, reunimos todos os presidentes, diretores, técnicos, engenheiro técnico das companhias de abastecimento de água do pais [...] fizemos o Primeiro Congresso Internacional de Odontologia voltado para a qualidade da água, para o consumo e foi a primeira vez que a odontologia se reuniu com engenheiros [...] Eu percorri todas as capitais do Brasil, reunimos o secretário de saúde do estados ou do município, ABO, o Conselho, representantes da companhia de abastecimento de água, representante da Caixa Econômica Federal e tinha mais gente. Esse grupo tinha a responsabilidade de receber o recurso da Caixa Econômica e comprar oflúor [...] além da fluoretação de água de abastecimento público, o Vitor [Gomes Pinto] estava na frente e nós fizemoso primeiro levantamento epidemiológico da carie dental no Brasil.

Assim, o primeiro inquérito epidemiológico específico de Saúde Bucal foi coordenado pelo IPEA, em 1986 (PINTO, 2014), e, no nível nacional, foi realizado em 16 cidades, apenas em área urbana, tendo sido priorizadas as cidades que tivessem boa representatividade regional e que possuíssem representação da FSESP. (BRASIL, 1986c) Devido à escassez de recursos, limitou-se o inquérito aos grupos etários 6-12, 15-19, 34-44 e 50-59 anos e os problemas investigados foram:

- cárie dental - 6,65 CPO-D aos 12 anos (um dos maiores do mundo);

- problemas periodontais;

- uso e necessidade de prótese; e (iv) demanda por serviços. (BRASIL, 1986c)

31 Entrevista concedida à autora por Benedito Elias Waquim em dezembro de 2014.

32 Benedito Elias Waquim nasceu em São Luís (MA), onde concluiu seu curso de graduação em Odontologia. Fez residência no Hospital do Câncer no Instituto Nacional de Câncer (INCA). Foi consultor do Ministério da Saúde, desde 1977, depois, tornou-se o responsável pela implantação do Programa Nacional de Prevenção e Diagnóstico do Câncer de Boca da Divisão em Educação, tendo produzido dois manuais. Participou do GT-Odonto, da Divisão Nacional de Saúde Bucal e foi Coordenador Nacional de Saúde Bucal na década de 1990. Entrevista concedida à autora, Salvador, 2014. 


\section{CONDIÇÕES DE POSSIBILIDADE HISTÓRICAS PARA A EMERGÊNCIA DE POLÍTICAS DE SAÚDE BUCAL NO PÓS-CONSTITUINTE}

\section{Papel do Instituto de Pesquisas Econômicas Aplicadas (IPEA) e Finsocial}

Além de ter servido como lócus para elaboração do Praod, o Instituto de Pesquisas Econômicas Aplicadas desempenhou um papel importante no espaço de formulação das políticas de saúde bucal, no início dos anos 1980. Em publicação recente do Instituto, diz-se sobre o seu papel de "refletir sobre os principais problemas nacionais, visando o aperfeiçoamento das políticas públicas em diversos campos”. (IPEA, 2008) O mesmo também foi ressaltado pelos entrevistados Pinto e Vianna, em 2014.

O gerenciamento do financiamento da expansão da fluoretação no país ficou a cargo do Banco Nacional da Habitação (BNH), substituído posteriormente pela Caixa Econômica Federal (CEF). Já as ações de saúde do escolar ficaram localizadas na Fundação de Assistência ao Estudante (FAE) do MEC. (PINTO, 1993) As ações que compunham o Finsocial não passaram por processo de planejamento e a saúde bucal entrou no último momento. Solon Magalhães Vianna e Vitor Gomes Pinto foram responsáveis pela formulação dos programas.

Esse programa nacional que continha diretrizes políticas para a saúde bucal emerge da possibilidade de recursos pelo Finsocial, dentro do Plano de reorientação da assistência odontológica IPEA, que representava um espaço de formulação de políticas. Solón Magalhães Vianna ingressou no Instituto em 1975, após ter exercido a direção do Departamento de Planejamento de Saúde da Secretaria de Saúde de Brasília. Vitor Gomes Pinto também ingressou no mesmo ano, quando estava se formando um núcleo de saúde, com o Eduardo Kertész. As propostas de 
ação que constavam dos documentos oficiais do IPEA, assinados por Vianna e Pinto, envolviam a priorização para a região Nordeste, os sistemas de abastecimento de maior alcance social, reativação dos sistemas desativados até junho de 1983 e participação popular e das companhias de saneamento para que as medidas tivessem continuidade após findada a participação do Finsocial para a fluoretação das águas de abastecimento público. (VIANNA; PINTO, 1983)

Observou-se que o IPEA passou a exercer importância nas ações de saúde bucal no âmbito nacional, justificada pelo espaço aparentemente neutro que exercia frente aos conflitos que existiam entre o MS e o MPAS. Ademais, seus membros ocupavam uma posição dominante, sendo identificados como experts de estado em relação ao campo do poder. Nesse sentido, esses membros, muitas vezes tendo saído do seu campo de origem, não eram identificados conforme suas formações profissionais de início.

\section{Luta pela democratização e a saúde}

Escorel (2008) e Paim (2008) relacionaram o momento histórico de luta pela democratização do país com as lutas setoriais na saúde relacionadas com a reforma do sistema de saúde. Paim (2008) analisa a Reforma Sanitária Brasileira como uma reforma social centrada na democratização da saúde, democratização do Estado e democratização da sociedade; um fenômeno histórico social que pode ser descrito conforme o ciclo ideia-proposta-projeto-movimento-processo.

A ideia se relaciona a sua representação inicial. A criação do Cebes, em 1976, e o lançamento da Saúde em Debate assim como a fundação da Associação Brasileira de Saúde Coletiva (Abrasco), em 1979, foram consideradas pelo autor como expressão da síntese das práticas teórica e política. (PAIM, 2008) A proposta correspondeu ao conjunto articulado de princípios e proposições políticas, sendo que o projeto foi sistematizado no Relatório Final da VIII Conferência Nacional de Saúde (CNS). O movimento de democratização da saúde emerge com o Cebes e perpassa distintas conjunturas. Já a Reforma Sanitária Brasileira (RSB) enquanto processo foi desencadeada após a VIII CNS com a implantação do Sistema Unificado e Descentralizado de Saúde (SUDS), a instalação da Comissão Nacional de Reforma Sanitária e a própria promulgação da Constituição Federal, em 1988. (PAIM, 2008)

No bojo do movimento da RSB, na luta pela democratização, surgem movimentos dos dentistas com pautas pela democratização do país e pautas específicas para formalização de respostas do Estado frente aos problemas bucais que serão tratados a seguir. O momento de elaboração da Constituição Federal, a partir de 1985, promulgada em 1988, é caracterizado como um grande período de lutas. 


\section{Encontros Nacionais de Administradores e Técnicos de Serviços Públicos (Enatespo)}

Em dezembro de 1984, foi realizado o I Encontro Nacional de Administradores e Técnicos de Serviços Públicos Odontológicos (Enatespo) com o tema "proposta de política nacional para um governo democrático”, em Goiás. Serra (1998) caracterizou o Enatespo como um movimento contra-hegemônico nos anos 1980. O Enatespo ocorreu em um cenário de crescimento dos movimentos de redemocratização do país, o que estimulou a reconquista dos espaços políticos para discutir o país e posições políticas acerca dos problemas nacionais, e, assim, reuniu representantes da Odontologia que exerciam cargos no campo burocrático, instituições de ensino, entidades de classe e serviços odontológicos.

[...] até em 82 os Governadores não eram eleitos por voto popular. Eles eram eleitos indiretamente pela assembleia legislativa. Em 82, houve eleições diretas para governadores, então em vários estados foram eleitos governadores de oposição à ditadura militar. Portanto, a partir de 83, novos secretários estaduais de saúde, novos coordenadores, pessoas incumbidas da saúde bucal assumiram essas funções onde a oposição ganhou. Essas pessoas trataram de se articular a nível nacional. Nós inventamos o Enatespo, nós criamos um encontro nacional que chamamos de Encontro Nacional de administradores e técnicos do serviço público odontológico, a sigla é Enatespo. [...] vem com influência do Movimento Brasileiro de Renovação Odontológico, tem todo um processo que vai desembocar no Enatespo [...]. (Entrevistado 10, dentista, professor universitário)

A própria denominação do Enatespo expressa o lócus inicial de motivação do evento no campo burocrático enquanto administradores e técnicos do serviço odontológico, conforme apontou um dos entrevistados. O relatório final expressava sugestões para a elaboração de proposta de uma política de saúde pública em Odontologia no nível nacional:

- incentivo à indústria nacional de medicamentos para produção de material odontológico;

- padronização, no nível nacional, de ações preventivas e curativas, priorizando faixas etárias que são epidemiologicamente mais vulneráveis à cárie dental com técnicas e equipamentos simplificados para ampliar a cobertura, com menor custo, mas sem comprometer a qualidade, assim como desenvolver campanhas educativas a nível nacional;

- definição de níveis de complexidade e responsabilidade crescentes e convênio com universidades para encaminhamento de casos especializados; 
- decretação do Dia Nacional de Prevenção das Doenças Bucais com propostas de prevenção do câncer oral e aplicação de flúor, dentre outras;

- regionalização dos serviços e municipalização;

- aumento do subsídio para levar o dentista para a zona rural;

- fluoretação das águas e aplicação tópica de flúor;

- criação de departamentos de Odontologia autônomos, operacional e financeiramente, nas esferas federal, estadual e municipal;

- recursos humanos auxiliares;

- estabelecimento de um Conselho Nacional e Estadual de Odontologia com a participação de dirigentes de vários órgãos e mobilização nacional de direções odontológicas; $\mathrm{e}$

- promover a criação de fábricas de equipamentos simplificados nos estados. (ENATESPO, 1984)

É importante ressaltar a utilização de "política de saúde pública em Odontologia” e não de saúde bucal, o que expressa um espaço da saúde bucal coletiva ainda não consolidado. Ademais, no documento é feita a defesa do sistema incremental e da Odontologia simplificada, mas, também, de uma rede hierarquizada de serviços com maior autonomia dos municípios e estados assim como maior participação das universidades. O Enatespo surge em um cenário de abertura democrática e com um posicionamento de diálogo com o governo da Nova República frente aos problemas de saúde bucal da população brasileira, além de caracterização e crítica ao campo odontológico quanto à atuação do cirurgião-dentista. Segundo o Entrevistado 10 ademais constitui-se na convergência de interesses por participação no debate nacional sobre as políticas de saúde bucal até então monopolizado pela gestão do Inamps e das secretarias de saúde.

No informativo do Conselho Regional de Odontologia de São Paulo, de março de 1985, tratou-se das principais discussões realizadas no I Enatespo. O primeiro ponto retratado foi o apoio à bandeira da RSB com a garantia de acesso a serviços de assistência à saúde como direito básico de cidadania e dever do Estado brasileiro, além da transferência imediata do Inamps ao Ministério da Saúde. (CRO/SP, 1984) Participaram do evento muitos dentistas, dentre os quais cita-se o professor universitário Volnei Garrafa, da UnB, Hélio Wanderley Uchoa, que era da FSESP, Benedito Elias Waquim, do GT-Odonto, Vitor Gomes Pinto, do IPEA, Jovair Oliveira Arantes, filiado ao Partido do Movimento Democrático Brasileiro (PMDB), na época, e que depois se torna deputado federal, Sylvio Palermo Gevaerd, de Curiti- 
ba, e Paulo Capel Narvai, coordenador estadual de São Paulo. Djalmo Sanzi Souza também é citado como um dos organizadores do evento. (CRO/SP, 1984)

O II Enatespo ocorreu no ano seguinte, em 1985, na cidade de Curitiba (PR) e teve como tema central as Ações Integradas de Saúde (AIS). O evento defendeu a participação da Odontologia nas comissões técnicas das Comissões Interinstitucionais de Saúde (CIS) e nas Comissões Interinstitucionais Municipais de Saúde (CIMS), além de fazer um destaque para a necessidade do CFO incentivar a formação do pessoal auxiliar em Odontologia. (SERRA, 1998)

Já o III Enatespo ocorreu em Belém (PA), em setembro de 1986, tendo debatido a I Conferência Nacional de Saúde Bucal que ocorreria no mês seguinte, outubro de 1986. Os temas debatidos na terceira edição do evento foram:

- estrutura organizacional para atendimento escolar;

- participação efetiva da Odontologia nas AIS;

- sobretaxação de materiais odontológicos;

- classificação dos mesmos dentro do Ministério da Saúde e retirada do Imposto sobre Circulação de Mercadorias (ICMS);

- isonomia salarial e criação de cargos e cursos nas áreas de Técnico de Higiene Dental, Técnico em Prótese Dental e agentes de saúde.

As demandas por participação do dentista nas Comissões Interinstitucionais persistiam como alternativa para a participação efetiva da Odontologia nas AIS. (SERRA, 1998)

Os Enatespo estiveram relacionados com as políticas de saúde bucal, constituindo-se como polo dominante ou dominado, a depender do momento histórico, destinado à crítica das respostas do Estado aos problemas bucais da população. As discussões nos encontros culminavam em relatórios que apresentavam propostas para as políticas, com mudanças nos modelos de atenção apresentados ao longo dos anos, à medida que se lograva avanços no campo científico. Muitas pautas eram semelhantes àquelas do MBRO, a exemplo da recomendação de um Conselho Nacional e Estadual de Odontologia (1984) ou Conselho Nacional de Saúde Bucal (1988). Muitas propostas dos Enatespo foram contempladas na formulação das políticas de saúde bucal, como a fluoretação das águas, formação de pessoal auxiliar, sistema incremental voltado para o escolar, na política de 1989. Algumas destas propostas eram preconizadas desde a década de 1950, como o Sistema Incremental, pela FSESP, ratificadas pela Odontologia Sanitária e Social (Quadro 5). 
Observou-se poucas incorporações das propostas nas políticas do início da década de 1990. Em seguida, a proposta de inclusão da equipe de saúde bucal no PSF representava uma pauta dos Enatespo assim como as diretrizes da PNSB de 2004 expressam um conjunto de sugestões caracterizadas nos relatórios finais dos Encontros desde a década de 1980.

Alguns participantes e lideranças dos Enatespo exerceram funções de assessoramento da Coordenação de Saúde Bucal, ao longo dos anos, a exemplo de Sylvio Gevaerd, Djalmo Sanzi Souza, Paulo Capel Narvai, Marco Manfredini, Helenita Ely, Idiana Luvison, José Carrijo Brom, Rozangela Camapum, Moacir Tavares, Marcos Azeredo Werneck, Petrônio Martelli, Cleber Ronald Inácio dos Santos, Christian Mendez Alcântara, Marco Aurélio Peres. Destaca-se que todos os membros da Comissão de Assessoramento de 2004 eram integrantes dos Enatespo. Os funcionários da Divisão Nacional de Saúde Bucal assim como os gestores participavam dos Encontros, como Vitor Gomes Pinto, que esteve presente no primeiro Enatespo; Sonia Dantas e Gilberto Pucca Jr. também participaram dos eventos.

Os Enatespo ganharam proporções maiores incorporando ações do campo científico, como o Congresso Brasileiro de Saúde Bucal e apresentações de trabalhos científicos, assim como do campo burocrático, os Encontros dos Coordenadores Estaduais de Odontologia com o apoio do Ministério da Saúde.

\section{Quadro 5 - Principais críticas/propostas relacionadas às políticas de SB nos documentos dos Enatespo}

\begin{tabular}{|c|c|}
\hline Evento & Principais críticas/propostas relacionadas às políticas de SB* \\
\hline I Enatespo & $\begin{array}{l}\text { O relatório final expressou a elaboração de proposta de política de saúde pública em } \\
\text { Odontologia a nível nacional. Os participantes do evento recomendaram: incentivo } \\
\text { à Industria Nacional de Medicamentos para produção de insumos odontológicos; } \\
\text { padronizar as ações preventivas e curativas no nivel nacional, priorizando por faixas etárias } \\
\text { epidemiologicamente mais vulneráveis à cárie, utilizando a simplificação de acordo com } \\
\text { as necessidades locais; convênios com as universidades para encaminhamento de caso } \\
\text { que demandassem atenção especializada; decretação do Dia Nacional de Prevenção das } \\
\text { Doenças Bucais com propostas de campanhas de prevenção do câncer oral e aplicação } \\
\text { de flúor; aumento de subsidio para fixação do CD no meio rural; incentivo aos programas } \\
\text { preventivos - fluoretação das águas, bochechos com flúor, aplicação tópica de flúor, } \\
\text { comprimidos de flúor e aplicação de selantes; estabelecimento de um Conselho Nacional } \\
\text { e Estadual de Odontologia; implementação do sistema incremental, equipamento } \\
\text { simplificados, saúde do escolar; instituir cursos de formação de auxiliar de Odontologia e } \\
\text { Higienista Dental; definição de níveis de complexidades e responsabilidades crescentes em } \\
\text { relação ao atendimento odontológico - serviços básicos com o município, intermediário } \\
\text { com os governos estaduais e serviços especializados e complexos com o Ministério da Saúde } \\
\text { e Ministério da Previdência; desenvolver campanhas educativas de nível nacional. }\end{array}$ \\
\hline V Enatespo & $\begin{array}{l}\text { O relatório final apontou que os programas padronizados de âmbito nacional ou estadual } \\
\text { não podiam ser aceitos passivamente, a Divisão Nacional de Saúde Bucal (DNSB) deveria } \\
\text { providenciar para que fosse oficialmente criado o Conselho Nacional de Saúde Bucal (CNSB) } \\
\text { composto por representantes macrorregionais, estaduais e municipais. Esse Conselho } \\
\text { deveria ser responsável por formular o Programa Nacional de Saúde Bucal e deliberar } \\
\text { as medidas necessárias para a implantação. A DNSB deveria evitar pacotes técnicos } \\
\text { inadequados às realidades locais e apoiar as deliberações do I CNSB. Importância da } \\
\text { educação continuada e da formação do pessoal odontológico. }\end{array}$ \\
\hline
\end{tabular}




\begin{tabular}{|c|c|}
\hline Evento & Principais críticas/propostas relacionadas às políticas de SB* \\
\hline VI Enatespo & $\begin{array}{l}\text { O documento final reconheceu a criação da DNSB mas apontou para propostas ainda } \\
\text { não concretizadas: acesso universal, controle e avaliação, maior rigor nos produtos } \\
\text { odontológicos, remuneração justa e plano de carreiras para os trabalhadores, fluoretação } \\
\text { nas águas e no dentifrício, criação de um colegiado com representantes estaduais e } \\
\text { municipais. Críticas às lógicas de mercado hegemônicas. Quanto aos modelos assistenciais, } \\
\text { foram defendidos vários níveis de integração, sendo desenvolvida pela Administração direta. } \\
\text { O eixo condutor seria a redução dos níveis da cárie, periodontopatias e outras patologias. } \\
\text { Foi ratificada a importância do acesso a serviços de maior complexidade. As ações de saúde } \\
\text { bucal deveriam estar integradas num modelo de atenção integral à saúde das pessoas. } \\
\text { Foram também preconizados a formação profissional e a importância da intersetorialidade. }\end{array}$ \\
\hline VII Enatespo & $\begin{array}{l}\text { As açães de saúde bucal deveriam basear-se na Odontologia Integral, privilegiando a } \\
\text { manutenção e promoção da saúde bucal e buscando a redução e o controle das doenças } \\
\text { bucais no país. Os serviços deveriam ser reorganizados com base no novo modelo } \\
\text { assistencial com formação para as equipes de saúde bucal. Discutiu-se isonomia salarial e } \\
\text { definição de um plano de carreira adequado. A DNSB deveria consolidar-se como instância } \\
\text { política normativa e não executiva para formulação de diretrizes nacionais adequadas } \\
\text { às realidades locais. A PNSB deveria ser definida e implementada por um colegiado } \\
\text { com representantes de estados e municípios. A DNSB deveria posicionar a PNSB junto } \\
\text { às demais políticas de saúde, práticas sociais e econômicas do governo, consolidando a } \\
\text { municipalização. Deveria também incentivar a difusão das ações de educação para a saúde } \\
\text { bucal com trocas de experiências que sirvam de referências para os diversos serviços. }\end{array}$ \\
\hline VIII Enatespo & $\begin{array}{l}\text { Crítica às práticas odontológicas que não contribuiam para reversão do quadro } \\
\text { epidemiológico, necessidade de construção de novo modelo de atenção odontológica } \\
\text { baseado na universalidade, equidade, integralidade e controle social. Apontou-se a } \\
\text { necessidade de apoio politico-administrativo financeiro para a participação do componente } \\
\text { odontológico nos projetos municipais de saúde, busca pela implementação de modelos } \\
\text { assistenciais considerando a necessidade epidemiológica e sociais de cada região, } \\
\text { integralidade em saúde bucal. O projeto municipal de saúde precisava conter estudo } \\
\text { aproximado da realidade contemplando os determinantes sociais, a identificação de } \\
\text { problemas de saúde bucal a partir da epidemiologia, modelo assistencial baseado na } \\
\text { integralidade das açães de SB com ênfase nas açães básicas, método preventivo-educativo, } \\
\text { utilização de pessoal auxiliar, sistemas de trabalho de cobertura ampla, criar centros de } \\
\text { referência para atenção de níveis secundário e terciário, criar sistemas de referência e } \\
\text { contra referência, instrumentos adequados para avaliar o impacto das ações desenvolvidas, } \\
\text { definição clara dos recursos financeiros. Destacaram-se também os recursos humanos e } \\
\text { o controle social. Texto de autoria de Djalmo Sanzi Souza publicado na Revista do Cebes } \\
\text { dedicada ao Enatespo. Esse texto também foi entregue à coordenação de saúde bucal } \\
\text { no âmbito da consultoria prestada. O presidente do Enatespo foi Paulo Capel Narvai. } \\
\text { Comissão executiva: Djalmo Sanzi Souza, Joyce Capelli, Marco Aurélio de Anselmo Peres, } \\
\text { Paulo Fernando Capucci, Paulo Ivo Vantine, Rubens Mendes Diosdado, Tania Regina Feres } \\
\text { Siqueira. Comissão Científica: José Paulo Gouveia de Toledo e Marco Antonio Manfredini. } \\
\text { Paulo Frazão integrava a Comissão da Revista, juntamente com Carlos Botazzo. Douglas } \\
\text { Augusto Schneider Filho participou da Comissão de Comunicação Social. }\end{array}$ \\
\hline$X$ Enatespo & $\begin{array}{l}\text { Discutiu a saúde bucal no processo de municipalização da saúde. Ocorreu debate sobre } \\
\text { "Políticas de saúde para a próxima administração federal" com representantes dos } \\
\text { candidatos à presidência da república. Foram apontados problemas de financiamento ao } \\
\text { SUS que se refletiam na saúde bucal. A assembleia deliberou por incentivar a participação } \\
\text { da sociedade no controle das açães de saúde bucal, posicionar a política de SB junto às } \\
\text { demais políticas de saúde, sociais e econômicas do governo no sentido de garantir sua } \\
\text { efetivação e repasse aos estados e municípios, consolidando a municipalização; estimular } \\
\text { políticas de educação em saúde bucal e de vigilância em saúde, negando a hegemonia do } \\
\text { modelo clínico predominante no Brasil; ampliar a fluoretação das águas; rejeitar critério de } \\
\text { financiamento baseado no pagamento por prestação de serviços e estabelecer parâmetros } \\
\text { e fluxos de repasse automático do nível federal para o municipal; colocar em prática que o } \\
\text { SUS deve ordenar a formação dos recursos humanos; estimular a formação de técnicos em } \\
\text { higiene dental (THD), auxiliar de consultório dentário (ACD), Técnico em Prótese Dentária } \\
\text { (TPD) e técnicos em manutenção de equipamentos, regulamentando a formação da equipe } \\
\text { em saúde bucal. Comissão relatora: Djalmo Sanzi Souza, Carlos Botazzo, Sergio Fernando } \\
\text { Torres de Freitas, Volnei Garrafa, Marco Aurélio de Anselmo Peres. Colaboradores: Paulo } \\
\text { Capel Narvai, Samuel Jorge Moyses, Sergio Benedito Franco. }\end{array}$ \\
\hline XII Enatespo & $\begin{array}{l}\text { O relatório final, intitulado Carta de Curitiba, recomendou a realização de inquérito } \\
\text { epidemiológico nacional, o estabelecimento de uma rede de informaçães epidemiológicas } \\
\text { sobre saúde bucal, mudança do modelo de atenção transcendendo seu caráter individual, } \\
\text { remuneração dos trabalhadores não pautada na produção. Lançamento da primeira edição } \\
\text { do Congresso Brasileiro de SBC, como atividade simultânea. Foi registrada neste Enatespo, a } \\
\text { inclusão da equipe de saúde bucal no PSF em Curitiba, em período anterior à formalização } \\
\text { federal feita no MS/CNSB. }\end{array}$ \\
\hline
\end{tabular}




\begin{tabular}{|c|c|}
\hline Evento & Principais críticas/propostas relacionadas às políticas de SB* \\
\hline XIII Enatespo & $\begin{array}{l}\text { Defendeu um modelo de atenção no qual a saúde bucal deixasse de ser privilégio das } \\
\text { elites para tornar-se "uma conquista da sociedade e obrigação do poder público"; o } \\
\text { aprofundamento das conquistas sociais e a presença do Estado como indutor das políticas } \\
\text { públicas. }\end{array}$ \\
\hline XIV Enatespo & $\begin{array}{l}\text { Inserção da saúde bucal no Piso de Atenção Básica (PAB), abordagem multidisciplinar para } \\
\text { atenção em saúde bucal, os programas de saúde bucal devem ser direcionados a partir da } \\
\text { epidemiologia e não selecionar determinados grupos populacionais para o atendimento, } \\
\text { incentivo à inclusão da SB no PSF, realização de outros inquéritos epidemiológicos que } \\
\text { contemplassem em seu desenho os determinantes sociais da saúde, consolidação da } \\
\text { equipe de saúde bucal (CD, THD, ACD, TPD, APD), promover capacitação integral dos } \\
\text { recursos humanos. O relatório registra uma moção de repúdio à coordenadora nacional de } \\
\text { saúde bucal, afirmando que ela não representava o posicionamento dos trabalhadores do } \\
\text { setor, afirmando que sua prática era contrária ao desenvolvimento e fortalecimento do SUS. }\end{array}$ \\
\hline XV Enatespo & $\begin{array}{l}\text { O relatório final apontou a precariedade das informações disponiveis sobre os montantes de } \\
\text { recursos destinados à saúde bucal, sendo que os dados disponíveis indicavam diminuição } \\
\text { dos recursos para área nos últimos anos; reconheceu a importância da inclusão dos } \\
\text { profissionais de odontologia (CD, THD e ACD) nas equipes de saúde da família e o Programa } \\
\text { de Agentes Comunitários de Saúde; reconheceu que o PACS e o PSF permitiam ir além das } \\
\text { estratégias restritas praticadas por privilegiar o território e a família; reforçou a importância } \\
\text { dos procedimentos coletivos para a revisão dos quadros epidemiológicos e da superação } \\
\text { das dificuldades decorrentes dos diferentes padrões salariais entre os profissionais do } \\
\text { PSF, desenvolver mecanismos de educação continuada para profissionais do serviço não } \\
\text { inseridos no PSF, necessidade de fomento e ativação de centros formadores de pessoal } \\
\text { de nível médio; inclusão de dentistas na vigilância sanitária. Foram recomendados: } \\
\text { implementar incentivo no PAB aos municípios com ações de SB no PACS ou PSF, unicidade } \\
\text { e integralidade no papel do ACS frente ações preventivo-promocionais em saúde } \\
\text { bucal, reconhecer que o financiamento do setor era um desafio político “que requer do } \\
\text { coordenador de odontologia e equipe com maior capacitação técnica e ação estratégica } \\
\text { na captação dos recursos"; incorporar participação e saber popular nos serviços; realizar } \\
\text { estudos objetivos sobre o custo da Odontologia no Brasil; necessidade de integração entre } \\
\text { coordenadores estaduais e deste com a coordenação nacional; efetivar um apolítica salarial } \\
\text { para o SUS e implantação de cargos e salários. Relatoria: Paulo Capel Narvai, Djalmo Sanzi } \\
\text { Souza, Ruth Brito. }\end{array}$ \\
\hline XVI Enatespo & $\begin{array}{l}\text { Crítica à prática odontológica vigente. Necessidade de novas ações e medidas capazes de } \\
\text { regular práticas de mercado e/ou nos serviços públicos, assim como, de novos mecanismos } \\
\text { mais substantivos de relacionamento entre o Estado e mercado. Importância de construir } \\
\text { uma base política setorial nacional. Discutiu a Agenda } 21 \text { da saúde bucal e o acesso aos } \\
\text { serviços. Debateu o PSF e a saúde bucal em uma das oficinas temáticas com Flávio Andrade } \\
\text { Goulart, professor do departamento de Saúde Coletiva da UnB, um Sistema Nacional de } \\
\text { Informações em Saúde Bucal com o Paulo Capel Narvai, da Faculdade de Saúde Pública } \\
\text { (FSP) da USP. }\end{array}$ \\
\hline
\end{tabular}

*A partir da análise de relatórios finais, anúncios do evento, textos e programação divulgados, cedidos pelos entrevistados.

Fontes: elaboração pela autora. ${ }^{33}$

\section{Conferência Nacional de Saúde e I Conferência Nacional de Saúde Bucal}

A VIII Conferência Nacional de Saúde ocorreu entre 17 e 21 de março de 1986 e teve como temas "Saúde como Direito", "Reformulação do Sistema" e "Financiamento do Setor”. (BRASIL, 1986d; PAIM, 2008) Muitos participantes das três grandes mesas redondas eram vinculados ao movimento sanitário. Paim (2008)

33 A partir das revistas Ação Coletiva e dos documentos finais dos Enatespo. 
destaca, através da análise do relatório final da Conferência, que os principais elementos constitutivos do projeto da Reforma Sanitária foram construídos na VIII Conferência Nacional de Saúde:

- ampliação do conceito de saúde;

- reconhecimento da Saúde como um direito de todos e dever do Estado;

- criação do SUS;

- participação popular; e

- constituição e ampliação do orçamento social.

O relator geral da VIII Conferência foi Guilherme Rodrigues da Silva, tendo Solón Magalhães Vianna e Roberto Passos Nogueira como relatores.

A I CNSB ${ }^{34}$ incorporou as temáticas gerais da VIII CNS, tendo sido convocada pelo Ministério da Saúde, de 10 a 12 de outubro de 1986, em Brasília (DF), e contado com mais de 1000 participantes, entre representantes de entidades de classe, secretarias estaduais e municipais de saúde, Inamps, Associação Brasileira de Ensino Odontológico (Abeno), FSESP, Central Única dos Trabalhadores (CUT) e Comando Geral dos Trabalhadores (CGT), Associações de Moradores (Conam) e estudantes. Teve como temas:

- Saúde como direito de todos e dever do Estado;

- Diagnóstico de Saúde Bucal no Brasil;

- Reforma Sanitária: inserção da Odontologia no SUS; e

- Financiamento do setor de Saúde Bucal.

A I CNSB foi patrocinada pelo Ministério da Saúde e pela UnB. Esta Conferência representa parte do processo da Reforma Sanitária Brasileira que se constituiu em fórum para a aprovação de propostas específicas relativas à saúde bucal no Sistema de Saúde. No relatório final da Conferência, considerava-se que as conclusões produzidas representavam o que existia de mais democrático e progressista para a Odontologia e a sociedade civil organizada do país sobre saúde bucal até o momento. (BRASIL, 1986b) O estudo de Serra (1998) considerou que o evento representou o ápice de um processo longo e difícil de discussão da problemática de saúde bucal

34 A Conferência se estruturou em três dias: os dois primeiros foram iniciados com discussão em torno de grandes temas, no período da manhã; os grupos de discussões ficaram no período da tarde e a plenária final no último dia. 
da população brasileira de modo pluralista, essencialmente democrático, onde a população representada, teve voz e voto.

Volnei Garrafa, coordenador-geral; o presidente do CFO, Fernando de Souza Lapa; Paulo Freire, coordenador de Odontologia do Inamps; e Swendenberger Barbosa, secretário geral do evento formavam a comissão organizadora desta conferência. Na elaboração do relatório final estavam Carlos Botazzo, Lauro Nunes da Rosa, Ney Moraes, Renato Quintino dos Santos, com Jorge Cordón enquanto Assessor Especial. (BRASIL, 1986b) Paulo Frazão ${ }^{35}$ participou da Conferência como delegado e apontou que muitas teses aprovadas na conferência eram pautas do MBRO. ${ }^{36}$

Havia uma estreita articulação entre a CNSB e a VIII CNS. Lideranças do movimento sanitário, como Sérgio Arouca, Hesio Cordeiro e Cristovam Buarque, reitor da UnB, participaram da mesa "A saúde bucal: direito do cidadão e dever do Estado" ao lado de representantes das entidades odontológicas no período: Fernando de Souza Lapa, pelo CFO, Hésio Cordeiro, pelo Inamps, José Geraldo de Souza Jr., pela Conferência Nacional dos Bispos do Brasil (CNBB), Sergio Arouca, como presidente da $8^{\mathrm{a}} \mathrm{CNS}$ e Swendenberger Barbosa, como presidente do Sindicato dos Odontologistas do Distrito Federal (SODF).

No segundo dia, os painéis tratavam de "Reforma sanitária, a inserção da Odontologia no Sistema Único de Saúde" e "Financiamento do Setor" com os painelistas Eugênio Vilaça Mendes, pela Organização Panamericana da Saúde (OPAS)/OMS, Fabíola de Aguiar Nunes, representando o Ministério da Saúde, Paulo Capel Narvai, pelo Instituto de Saúde de São Paulo, Sério Pereira, pela Fundação de Educação do Governo do Distrito Federal, e Solón Magalhães Vianna, pelo IPEA. (BRASIL, 1986b)

No tema 1, destacou-se a posição da saúde bucal vinculada à luta pela melhoria de fatores condicionantes sociais, políticos e econômicos e se ressaltava a responsabilidade e o dever do Estado por sua manutenção. (BRASIL, 1986b) O relatório também apontou para a importância do controle social no planejamento, execução, monitoramento e avaliação dos Programas de Saúde Bucal.

No tema 2, a saúde bucal dos brasileiros foi adjetivada como caótica, apontando que apenas $5 \%$ da população tinham suas necessidades atendidas no modelo vigente, caracterizado como elitista, monopolizador, de altos custos de tecnologia densa, iatrogênico e mutilador. Somava-se a denúncia da inexistência de uma Política Nacional de Saúde Bucal voltada para os interesses da maioria da população assim como da ausência de recursos financeiros próprios ao setor e da falta de participação de controle da população nos programas. Foram também discutidos a inexistência

Entrevista concedida à autora, em São Paulo no ano de 2014. 
de dados epidemiológicos fidedignos, a pouca utilização de pessoal auxiliar, a não utilização de métodos preventivos de nível elementar coletivo, de forma sistematizada, o descumprimento da legislação quanto à fluoretação das águas, a ausência de ações de educação em saúde bucal, a "proliferação irracional de Faculdades de Odontologia” e a ausência de CD nos órgãos decisórios do atual sistema.

No tema 3, tratou-se que o "Programa Nacional de Saúde Bucal” deveria estar inserido no SUS. Foram abordadas a produção e a pesquisa em saúde bucal, a adoção de uma política de recursos humanos na saúde bucal, a formulação deste Programa como base nas diretrizes da área, respeitando as definições de cada esfera de gestão e estabelecendo as prioridades mínimas (faixa etária de 0 a 14 anos, gestantes, adulto, com concordância democrática da população atendida), a criação de prontuário único e o estímulo à organização comunitária e à ampla publicidade aos alimentos altamente cariogênicos, através de seus rótulos e propagandas. Discutiram o tema, Paulo Capel Narvai e Eugênio Vilaça Mendes com a coordenação de Swendenberger Barbosa. Mendes defendia o ponto de vista da articulação entre o Ministério da Previdência Social e o Ministério da Saúde, na perspectiva do que tinha sido o Prev-Saúde e as Ações Integradas de Saúde. Já Paulo Capel Narvai, entrevistado em 2014, defendia uma proposta de saúde bucal que ele identificava como de interesse do Movimento Operário Popular.

Essas posições podem se relacionar com a geração e as trajetórias. Eugênio Vilaça Mendes, nasceu em 24 de abril de 1940, em Pará de Minas (MG). Seu pai era dentista, sua mãe, professora primária e seus avós, comerciantes. Estudou em colégio privado, tendo optado pela Odontologia por influência de seu pai. Seguiu, primeiramente, a carreira de cirurgia, seguindo, posteriormente, pela Saúde Pública. Ele apresentava poucas disposições políticas, não tendo sido filiado a partidos políticos. Orientou sua carreira para a atuação em organismos internacionais tendo sido consultor da Odontologia Preventiva e Social (OPS), Banco Internacional para Reconstrução e Desenvolvimento (BIRD) e Fundação Kellog. Já Paulo Capel Narvai, nasceu em 15 de setembro de 1954, em Mandaguari (PR), filho de bancário, de mãe dona do lar e avós imigrantes agricultores. Optou pela Odontologia em virtude do seu caráter liberal e da autonomia profissional. Apresentava disposições políticas, tendo participado dos ECEO, era membro do Cebes de São Paulo e filiado ao Partido dos Trabalhadores (PT). Narvai apresentava maior capital político que Mendes, que, por sua vez, possuía maior capital científico que o primeiro, no período. Os dois apresentavam grande acumulação de capital burocrático.

Por fim, no tema 4, aprovou-se em plenário a criação de um Fundo Único Nacional de Saúde para o financiamento das ações, além da aplicação dos recursos 
nos níveis estadual e municipal. Cita-se, também, a isenção de impostos para a aquisição dos equipamentos odontológicos pelo setor público, a redução de impostos e taxas para importação de materiais odontológicos, além de uma demanda por dotação destinada e assegurada no Fundo Único de Saúde para a Saúde Bucal baseada nas necessidades populacionais.

Figura 3 - Capa do boletim do II ECEO

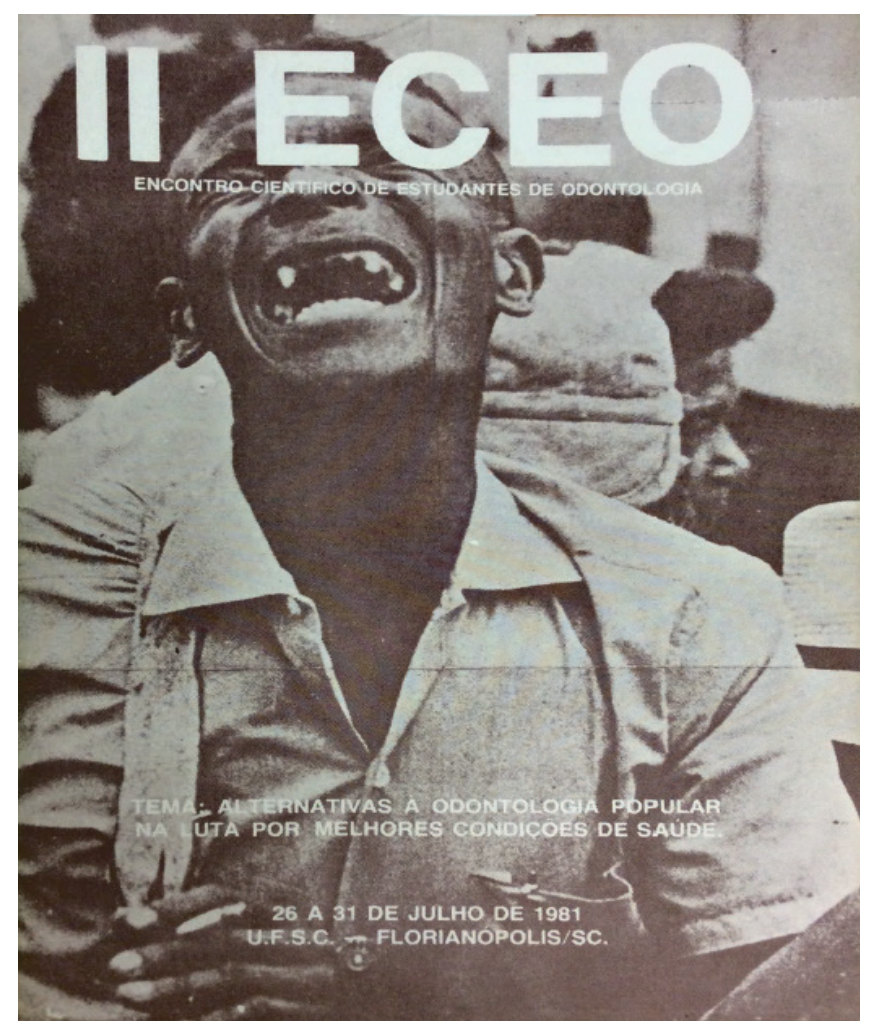

Nota: Charges que ilustraram os textos do II ECEO.

Fonte: Encontro Científico de Estudantes de Odontologia (1981).37

Antes de tratar especificamente do MBRO, cabe destacar que os ECEO juntamente com o Movimento e o Enatespo constituíram locais para discussão e crítica das políticas de saúde bucal. Eram espaços em favor da democratização da saúde, da universalização do acesso aos serviços de saúde bucal e do enfrentamento dos problemas odontológicos da população brasileira. Segundo o Entrevistado 15, muitos estudantes vinham tendo contato com o debate do fim da ditadura, da perspectiva de democratização e da possibilidade de uma outra Odontologia.

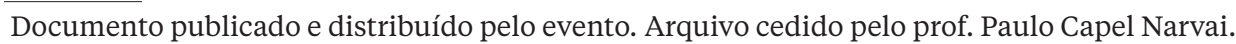


Os ECEO reuniam estudantes da área inspirados nos Encontros Científicos dos Estudantes de Medicina (ECEM), tendo sido organizados pelo movimento estudantil. Nesses encontros, eram debatidas questões relativas à democratização do país e sobre as políticas de saúde. O primeiro ECEO foi realizado no ano de 1979, na cidade de Vitória (ES), tendo sido precedido por discussões nos Pré-ECEO.

O II ECEO ocorreu em Florianópolis (SC), em 1981 (Figura 3). No boletim do II ECEO constaram textos sobre os temas:

- crítica à atual prática odontológica e suas relações com a formação de recursos humanos odontológicos, de Jorge Cordón;

- histórico da organização dos estudantes de Odontologia no Brasil;

- simplificação e desmonopolização em Odontologia, por Volnei Garrafa;

- considerações sobre a prática odontológica, por Paulo Capel Narvai;

- sobre a "História Social das Doenças", por Renato de Oliveira;

- a VII Conferência Nacional de Saúde. O Prev-Saúde em debate, publicado na revista Saúde em Debate pelo CEBES/Bahia.

\section{Movimento Brasileiro de Renovação Odontológica (MBRO)}

Muitos dentistas participaram dos ECEO: Volnei Garrafa, Jorge Cordón, Paulo Capel Narvai, Sérgio Pereira e Fernando Pires, como painelistas; e Marco Manfredini, Douglas Schneider, Marcos Werneck, Samuel Moysés e Paulo Frazão, como integrantes do movimento estudantil, dentre outros. O boletim era ilustrado com charges sobre diversos temas tratados no movimento sanitário, no MBRO e nos Enatespo, a exemplo da situação de saúde bucal dos brasileiros, da ditadura militar, da condição socioeconômica do país, dentre outros.

Ainda sobre as charges, destaca-se a ênfase no edentulismo, quando se observa um cidadão desdentado como símbolo da condição de saúde do cidadão brasileiro. A Pesquisa Nacional de Amostras por Domicílios (PNAD), do IBGE, publicada em 1986 mostrava que, dentre todos os brasileiros consultados que utilizaram serviços de saúde, apenas 4,8\% deles tiveram acesso a serviços odontológicos, com maior utilização dos residentes no Sul do país - Norte, 4,2\%; Nordeste, 4,4\%; Centro-Oeste, 4,6\%; Sudeste, 4,6\%; e Sul, 6,7\%. (IBGE, 1986)

Outros ECEO foram realizados, na década de 1980, e são considerados como responsáveis pela formação crítica dos profissionais da área de saúde bucal. (SERRA, 1998) De acordo com o Entrevistado 20, os ECEO levaram vários militantes para 
outros movimentos da época, como o MBRO e os Enatespo. Ademais, estudantes e profissionais que participaram dos ECEO passaram a integrar comissões de assessoramento no Ministério da Saúde, como Paulo Capel Narvai, Marco Manfredini e Marcos Werneck assim como Paulo Frazão, que integrou comissão sobre o inquérito epidemiológico nacional e também foi delegado na I CNSB.

Serra (1998), que analisou o MBRO, cita a iniciativa de dentistas do Conselho Regional de Odontologia de São Paulo (CRO-SP), da Associação Paulista de Cirurgiões Dentistas (APCD) e do Sindicato dos Odontologistas de São Paulo, em 1983, que criaram o Movimento de Renovação dos Odontologistas do Estado de São Paulo (MBROESP). O Entrevistado 20 apontou uma força aglutinadora do Movimento em São Paulo que impulsionou o MBRO no nível nacional.

[...] o Movimento de Renovação Odontológica do Estado de São Paulo foi o grande impulsionador do MBRO em nível nacional [...]. Por quê? Porque acho que em São Paulo houve um exemplo de uma unidade de forças contrárias ao então PDS que foi remanescente do ARENA do ponto de vista político-partidário. Então claramente eu entendo que na gênese, é lógico que não foi só São Paulo, mas eu acho que o exemplo político de construção de uma agenda coletiva aqui em São Paulo contribuiu muito para efetivação do Mbro em nível nacional. Você tem outros fatores que se somam também, você tem a questão dos ECEO que são os Encontros Científicos dos Estudantes de Odontologia, que foram retomados no final dos anos 70, que também acabaram por trazer vários militantes pra dentro do Mbro, você tem o surgimento dos Enatespos que são os Encontros Nacionais Administradores de Técnicos Serviços Públicos Odontológicos. [...] No nível nacional você tinha situações diferentes, sindicatos já identificados com propostas progressistas, serviços públicos onde você tinha técnicos trabalhando já identificados com gestões progressistas, intelectuais da universidade. [...]é um movimento que surge fruto daquela conjuntura política com vários agentes importantes na sua constituição. (Entrevistado 20, dentista)

Alguns meses após o I Enatespo foi fundado o MBRO. O Movimento, segundo seus boletins de divulgação, foi criado com o "intuito de estimular, a nível nacional a articulação dos profissionais da odontologia rumo a caminhos democráticos e populares”. (BOLETIM INFORMATIVO DO MOVIMENTO BRASILEIRO DE RENOVAÇÃO ODONTOLÓGICA, 1985a) O primeiro documento do MBRO, de fevereiro/ março de 1985, caracterizava o espaço de lutas e as distintas tomadas de posição dos dentistas: de um lado, aqueles dentistas e estudantes de Odontologia que tratavam a luta de resistência democrática ao lado dos profissionais e do povo e, do outro lado, as lideranças odontológicas que “davam os mais expressivos sustentáculos ao 
regime que condenava à miséria milhares de compatriotas e mergulhava o país na corrupção”. (BOLETIM INFORMATIVO DO MOVIMENTO BRASILEIRO DE RENOVAÇÃO ODONTOLÓGICA, 1985a) O boletim se opunha à mercantilização da prestação de serviços odontológicos e afirmava que o Estado brasileiro deveria assumir sua total responsabilidade e apoiava a expansão dos serviços próprios, a municipalização, o controle social, o aumento do financiamento para a assistência odontológica e a utilização de recursos humanos odontológicos. (BOLETIM INFORMATIVO DO MOVIMENTO BRASILEIRO DE RENOVAÇÃO ODONTOLÓGICA, 1985a)

Conforme o Entrevistado 20, muitos são os fundadores deste Movimento e, para organizar o processo inicial, foi criada uma comissão executiva provisória composta por João Roberto Peres Batista, de São Paulo, Paulo Capel Narvai, também de São Paulo e Volnei Garrafa, do Distrito Federal, que convocou assembleia do Movimento para 23 de março de 1985, em São Paulo.

Destaca-se que o MBRO se propunha a atuar em diversos âmbitos - sindicalismo, prática odontológica e formação de recursos humanos:

- contribuir para o estabelecimento de uma "Política Nacional de Saúde Oral” voltada para os interesses da maioria da população;

- luta pela liberdade política;

- oposição à mercantilização dos serviços odontológicos;

- democratização do acesso aos serviços de saúde bucal;

- apoio a movimentos populares;

- recursos humanos;

- ensino de qualidade;

- fortalecimento e democratização das entidades de classe odontológicas; e

- Luta na Assembleia Nacional Constituinte. (PRIMEIROS..., 1985)

O Movimento Brasileiro de Renovação Odontológica resulta do momento histórico de redemocratização do Brasil, das lutas pela saúde e no âmbito mais restrito da saúde bucal dentro da saúde, da grande insatisfação com os rumos da Odontologia pública, de como os programas eram definidos, das muitas críticas ao sistema incremental, ao modo de conduzir as definições dos programas da Odontologia pública, sobretudo no Inamps, mas, também, nas secretarias estaduais de saúde e educação, das características autoritárias, tecnocráticas, não abertas à gestão participativa, sem possibilidade de participação dos trabalhadores da área. Segundo o Entrevistado 10, as lutas dos profissionais de Odontologia apresentavam diver- 
gências, na década de 1980. Os entrevistados caracterizaram um ponto de vista das entidades de classe identificadas com a Odontologia liberal e de mercado com a defesa apenas dos interesses dos profissionais, mas, também, outro ponto de vista, do MBRO, de enfrentar o processo de assalariamento dos dentistas, etapa também vivenciada pela medicina, além da perspectiva de participar das lutas pela democracia e pela saúde no país. O MBRO aglutinava pessoas de distintos partidos políticos, mas com interesses semelhantes pelas pautas citadas.

A primeira coisa que eu acho era a saúde bucal pelos seus problemas e suas respostas versus a integração dela às outras áreas, acho que era o grande problema. Quando se discutia isso tudo em setores mais conservadores da Odontologia, que o importante era na base construir uma política de saúde bucal, onde a gente tivesse um aumento de recursos específicos para fazer [...] com que a estrutura da saúde bucal dentro de determinados órgãos do governo, seja federal, estadual, municipal, fosse reconhecida [...].Ou seja, de um lado um grau de corporativismo exacerbado, [...], numa visão muito elitista de que a gente ia se misturar [...]. (Entrevistado 23, dentista)

Sobre o movimento se chamar de renovação odontológica, os entrevistados apontaram razões distintas. O Entrevistado 3 remeteu a um espelhamento a posteriori do Movimento de Renovação Médica. O Entrevistado 15 também refere uma inspiração no movimento médico, mas aponta que não foi contemporâneo da Renovação Médica, tendo em vista que o MBRO já surgiu no processo de democratização. Já o Entrevistado 10 afirmou que o nome do Movimento remete aos seus objetivos de renovar as entidades odontológicas e as políticas de saúde bucal.

[...] chegou uma hora que tinha que dar um nome a isso, então era um movimento, movimento social, entendido como movimento social, então não tinha que ter diretoria, não tinha queterestatuto, não tinha que tersede, seria um movimentosocial que duraria enquanto ele fosse necessário como movimento social, que realizasse o seu objetivo. O seu objetivo era o que: renovar as entidades odontológicas e renovar as políticas de saúde bocal nas instituições pública. (Entrevistado 10, dentista)

No segundo boletim, intitulado "Primeiros Passos", destacavam-se os esforços maiores de participação e mudança de rota da Odontologia brasileira dos ECEO e dos Enatespo, assim como o inadiável surgimento do Mbro direcionado à contribuição para o estabelecimento de uma "Política Nacional de Saúde Oral" voltada para os interesses da maioria da população". (PRIMEIRO..., 1985, p. 1) Em São Paulo, decidiu-se que a assembleia geral seria o órgão máximo do Movimento 
e foi eleita a primeira coordenação nacional composta por Carlos Botazzo, Douglas Schneider, ambos de São Paulo, e Luiz Ben-Hur Loures, do Paraná. (PRIMEIRO..., 1985) Em entrevista concedida em 2014, Narvai estabelece alguns critérios para explicar que o MBRO concatenava pessoas de diversas vertentes:

- algumas pessoas da FSESP, chamados de primeiros sanitaristas;

- uma segunda geração de sanitaristas composta de pessoas como Sérgio Pereira;

- líderes dos movimentos estudantis;

- dentistas de organizações ligadas à luta clandestina contra a ditadura militar;

- pessoas que eram oriundas da academia; $\mathrm{e}$

- movimento sindical.

Além dos dentistas já citados, os entrevistados referiram outros dentistas que participaram do MBRO: Volnei Garrafa, Jorge Cordon, Lauro Consentino, Douglas Schneider, Marco Antônio Manfredini e Marcos Werneck.

Nos anos posteriores, ocorreram mudanças nas coordenações, como era pretendido pelo Movimento. De 1986 a 1987, fizeram parte da coordenação, Volnei Garrafa, Swendenberger Barbosa do Nascimento, Marcus Antônio Felix Ribeiro e Arlindo Gonçalves Ferreira. Os três primeiros eram de Brasília e o último de Belo Horizonte. No período seguinte (1987-1988) assumiram Luciano Elói Santos e Felix Araújo de Souza e Arlindo Gonçalves Ferreira permaneceu. Todos de Belo Horizonte. De janeiro a julho de 1989, integravam a coordenação nacional Douglas Augusto Schneider Filho, Paulo Capel Narvai e José Paulo Gouveia de Toledo (todos de São Paulo). (ZANETTI, 1993) O MBRO não possuía outra fonte de financiamento senão a de seus membros e neste sentido não realizava muitas reuniões nacionais. O MBRO não tencionava ser uma associação ou instituição, constituindo-se enquanto movimento que congregava dentistas de diferentes gerações e disposições políticas em torno de objetivos comuns. Muitos se conheciam antes desse período e, neste sentido, a articulação do grupo possibilitou a criação de um espaço de crítica e contestação das respostas do Estado frente aos problemas bucais.

No ano de 1985 houve intensa atividade do Movimento nos estados, com pauta sobre a assembleia constituinte, a retração do mercado de trabalho e o assalariamento dos dentistas, a formação de recursos humanos e pesquisa assim como crítica à prática odontológica então vigente. (O GRITO..., 1985) No boletim de agosto de 1985, trata-se sobre a população, que sempre esteve à margem de "uma atenção odontológica de boa 
qualidade”. (BOLETIM INFORMATIVO DO MOVIMENTO BRASILEIRO DE RENOVAÇÃO ODONTOLÓGICA, 1985b, p. 10) Caracterizava-se as entidades de classe como esvaziadas, bloqueando qualquer tipo de discussão e ausentando-se dos grandes debates nacionais. Além disso, afirmavam que enquanto os "dirigentes defendiam seus próprios interesses”. (BOLETIM INFORMATIVO DO MOVIMENTO BRASILEIRO DE RENOVAÇÃO ODONTOLÓGICA, 1985c, p. 12), a categoria enfrentava desemprego, salários e condições de trabalho péssimas nas empresas e clínicas populares, vínculos precarizados que "feriam a dignidade profissional". (BOLETIM INFORMATIVO DO MOVIMENTO BRASILEIRO DE RENOVAÇÃO ODONTOLÓGICA, 1985c, p. 12) Com isto, defendiam um novo sindicalismo, crítico e combativo. Destaca-se um predomínio de mensagens do "Centro-Sul” e uma crítica, no próprio boletim, que solicitava aos colegas dos outros estados que enviassem notícias. (BOLETIM INFORMATIVO DO MOVIMENTO BRASILEIRO DE RENOVAÇÃO ODONTOLÓGICA, 1985c) O Movimento se articulou ao projeto da Reforma Sanitária Brasileira.

O Movimento participou ativamente da primeira Conferência Nacional de Saúde Bucal, que foi um momento de grande expressão seu. Nos boletins que antecedem o evento, ficam nítidas as disputas entre o Movimento e as entidades de classe:

Os dentistas que integravam o MBRO tinham uma grande preocupação em registrar suas tomadas de posição através de boletins e, no ano de 1986, com o apoio do Cebes, os integrantes publicam seus textos em um número especial da revista Saúde em Debate, no número 18, de março/abril de 1986. A Revista tinha como temas Políticas de Saúde e Odontologia Comunitária e participação popular.

O MBRO participou do espaço da construção social das doenças bucais como um problema, posicionando-se criticamente frente aos problemas da população brasileira. Cada uma das tomadas de posição do MBRO será abordada quando tratarmos de cada uma dessas respostas do Estado, nos capítulos que se seguirão no presente trabalho. Nenhum dos dentistas entrevistados que fez parte do Movimento soube precisar quando ocorreu, especificamente, o seu fim. Entretanto, estudos de Serra (1998) apontam que a fase final do Movimento foi marcada por divergências internas quanto à fluoretação do sal no Brasil, no início da década de 1990, no governo Collor. Apesar de não existirem mais reuniões formais do Movimento, Entrevistado 15 acredita que as pautas do MBRO permanecem nas mentes e corações dos seus integrantes. Depois, participantes ocuparam cargos na política nacional, tendo fundado sindicatos nacionais como a Federação Interestadual dos Odontologistas (FIO), com Swendenberger Barbosa. De acordo com o Entrevistado 10 , outros integraram diretorias de sindicatos de odontologistas, disputaram e ganharam eleições para a $\mathrm{ABO}$ e suas regionais em vários pontos do país e começa- 
ram a exercer uma influência importante no próprio sistema do Conselho Federal de Odontologia (CFO) e Conselhos Regionais, a médio e longo prazo.

[...] as pessoas foram ocupando outros espaços, como muita gente era muito jovem também alguns foram tomando outros rumos profissionais, outra dimensão que foi o esvaziamento dos movimentos. Acho que nisso aí gente se pega o próprio processo da Reforma Sanitária já nos anos 90, a gente tem um refluxo dos movimentos e acho que há uma tendência das pessoas buscarem uma prática mais no seu local de trabalho, no seu âmbito, o que por um lado é positivo [...] e, por outro lado, o reflexo de um certo individualismo mesmo, a vida mais individual, menos espaços coletivos. (Entrevistado 15, dentista, professor universitário)

Considera-se que as principais bandeiras do MBRO, as mais imediatas, de certo modo, se resolveram com a conquista da democracia. Outras pautas também relacionadas ao movimento sanitário, como a saúde como um dever do Estado, a municipalização, o controle social, dentre outras, foram sendo contempladas com a implementação do Sistema Único de Saúde. Quanto às propostas específicas para as políticas de saúde bucal, o MBRO apontava diretrizes gerais a serem seguidas no nível nacional, mas não trazia muito detalhamento em suas propostas (Quadro 6). As políticas de saúde bucal incorporaram algumas pautas do Movimento. A PNSB de 1989 ratificou a fluoretação das águas, propostas de prevenção voltadas para a saúde do escolar, diretrizes voltadas à incorporação de pessoal auxiliar e reafirmou as práticas do Sistema Incremental. Pode-se afirmar que a incorporação da SB no Programa de Saúde da Família, que contou com fundadores do MBRO como consultores da Área Técnica de Saúde Bucal. A PNSB de 2004 também reforçou a fluoretação das águas, preconizou uma proposta mais abrangente de educação em saúde, recursos humanos, controle social, intersetorialidade, multiprofissionalismo e interdisciplinaridade, ampliação e qualificação da assistência.

Contudo, questões relacionadas à saúde bucal ainda estão na agenda, como o financiamento, o embate com os planos de saúde, com empresarial da saúde no campo odontológico, formação dos recursos humanos e crítica à prática odontológica vigente. Há, ademais, em concordância com Entrevistado 15, um desafio muito mais complexo, a tendência de isolamento da Odontologia com relação às outras profissões, a própria política nacional de 2004 que possui o mérito de ter produzido investimentos no setor, mas ainda expressa uma ação muito induzida pelo Ministério da Saúde. O entrevistado apontou que essas são questões que se precisa enfrentar e resolver para se consumar um sistema de saúde efetivamente transformador na saúde bucal. 


\section{Quadro 6 - Propostas e críticas específicas sobre as políticas de saúde bucal, nos documentos publicados pelo MBRO*}

\begin{tabular}{|c|c|c|}
\hline Boletim/ Revista & Propostas & Críticas \\
\hline $\begin{array}{l}\text { Boletim } n^{\circ} 1-\mathrm{fev} / \\
\text { mar - } 1985\end{array}$ & $\begin{array}{l}\text { Obrigatoriedade que o Estado assumisse a total } \\
\text { responsabilidade pela prestação de serviços } \\
\text { odontológicos, expansão dos serviços próprios, } \\
\text { municipalização, controle social, aumento } \\
\text { do financiamento com poderes para coibir a } \\
\text { mercantilização e poder para intervir no setor privado, } \\
\text { utilização de recursos humanos odontológicos } \\
\text { adequados à realidade socioeconômica e } \\
\text { epidemiológica, assim como sua justa remuneração. }\end{array}$ & $\begin{array}{l}\text { Prática odontológica } \\
\text { vigente, mercantilização } \\
\text { da prestação de serviços } \\
\text { odontológicos. }\end{array}$ \\
\hline $\begin{array}{l}\text { Boletim } n^{\circ} 2-\text { abril } \\
-1985\end{array}$ & $\begin{array}{l}\text { O boletim expressa o objetivo de "contribuir para o } \\
\text { estabelecimento de uma Política Nacional de Saúde } \\
\text { Oral realmente voltada aos interesses da maioria da } \\
\text { população" e ratifica as propostas do documento } \\
\text { anterior. }\end{array}$ & Idem boletim anterior. \\
\hline $\begin{array}{l}\text { Boletim } n^{\circ} 3-\text { maio } \\
\text { - } 1985\end{array}$ & O documento não expressa propostas. & $\begin{array}{l}\text { Os movimentos não } \\
\text { conseguiam influenciar } \\
\text { a implantação de } \\
\text { programas de saúde oral } \\
\text { que que privilegiassem } \\
\text { o atendimento "aos } \\
\text { enormes contingentes } \\
\text { populacionais, que vivem } \\
\text { à margem do sistema e } \\
\text { que, dispõem apenas de } \\
\text { serviços de baixíssima } \\
\text { qualidade para satisfação } \\
\text { de suas necessidades } \\
\text { historicamente } \\
\text { acumuladas". }\end{array}$ \\
\hline $\begin{array}{l}\text { Saúde em debate - } \\
\text { número especial do } \\
\text { MBRO - n } 18 / \text { mar- } \\
\text { abr } 1986\end{array}$ & $\begin{array}{l}\text { Pressupostos: simplificação, desmonopolização } \\
\text { (principalmente incorporação progressiva de } \\
\text { pessoal auxiliar, ampliação do objeto de trabalho), } \\
\text { transferência dos conhecimentos, estimular } \\
\text { capacidade crítica, formação e capacitação de } \\
\text { diferentes recursos humanos, prevenção. Sugestões: } \\
\text { revisão do papel dos serviços privados, participação } \\
\text { popular, financiamento - definição de } 10 \% \text { orçamento } \\
\text { da saúde para a Odontologia, concretização de um } \\
\text { "Plano Nacional de Saúde Bucal", política de utilização } \\
\text { da mão-de-obra do dentista no sistema público que } \\
\text { estimule a sua interiorização, contratação em vínculo } \\
\text { direto em substituição aos contratos e convênios, } \\
\text { utilização do sistema incremental como forma de } \\
\text { massificar o tratamento odontológico, educação } \\
\text { para profissionais de outras áreas e para a população, } \\
\text { fluoretação das águas de abastecimento público, } \\
\text { inclusão de conteúdos de prevenção nos conteúdos } \\
\text { didáticos escolares em vários níveis de ensino, } \\
\text { estímulo à indústria nacional. }\end{array}$ & $\begin{array}{l}\text { À Odontologia Liberal, à } \\
\text { ganancia e manutenção } \\
\text { do status quo pelos } \\
\text { profissionais. Necessidade } \\
\text { de transformação da } \\
\text { odontologia restrita ao } \\
\text { dente para a estomatologia } \\
\text { que abrange todo o } \\
\text { sistema estomatognático, } \\
\text { conhecimento a ser levado } \\
\text { à prática concreta à maioria } \\
\text { da população. }\end{array}$ \\
\hline $\begin{array}{l}\text { Documento "As } \\
\text { prioridades do } \\
\text { MBRO" - setembro } \\
\text { - } 1987\end{array}$ & $\begin{array}{l}\text { Defesa das resoluções da } 1^{\circ} \text { Conferência Nacional de } \\
\text { Saúde Bucal. }\end{array}$ & $\begin{array}{l}\text { O documento não formula } \\
\text { críticas específicas às } \\
\text { políticas de saúde bucal. }\end{array}$ \\
\hline $\begin{array}{l}\text { Boletim MBRO, abril } \\
\text { - } 1990\end{array}$ & O documento não expressa propostas. & $\begin{array}{l}\text { Crítica ao modelo atual de } \\
\text { prática odontológica. }\end{array}$ \\
\hline
\end{tabular}

* Os outros boletins não trazem críticas ou sugestões explícitas às políticas de saúde bucal, tratando de temáticas já abordadas.

Fonte: elaborado pela autora. 


\section{Do GT - Odonto à Divisão Nacional de Saúde Bucal (DNSB)}

O grupo responsável por debater a Odontologia e os serviços básicos de saúde na VII Conferência Nacional de Saúde, em 1980, fez o registro do momento em que se discutiu, pela primeira vez, aspectos relacionados à Odontologia no Programa Nacional de Saúde. O grupo teve como facilitadores Sérgio Pereira, ${ }^{38}$ e João Audifax Cesar de Albuquerque, ${ }^{39}$ tendo sido relatada por Fernando Molinos Pires. ${ }^{40}$

O documento da VII CNS tratava do caráter ineficiente, descoordenado, mal distribuído, de baixa cobertura e alta complexidade, com enfoque curativo, caráter mercantilista e monopolista com inadequação no preparo dos recursos humanos. As alternativas eram voltadas para as ações básicas de saúde bucal; adequação da formação de recursos humanos de nível superior, mas também técnico e auxiliar; medidas impeditivas da utilização de equipamentos com alta densidade tecnológica nos serviços públicos; linha de pesquisa na produção de insumos básicos para a Odontologia, no intuito de minimizar a dependência externa; estímulo à formulação de convênios com secretarias estaduais, serviços municipais e universidades, em detrimento da compra de serviços do setor privado; criação, no Ministério da Saúde, de um núcleo técnico voltado aos "problemas da odontologia” que se responsabilize pelo planejamento das ações odontológicas no país e definição política até então inexistente. (CONFERÊNCIA NACIONAL DE SAÚDE, 1980)

Em 1982, o então ministro dr. Waldir Arcoverde ${ }^{41}$ e a gestão do Secretário Geral do Ministério da Saúde, Mozart de Abreu e Lima, que era cirurgião-dentista (VIANNA, 1988; ZANETTI, 1993) constituiu o Grupo de Trabalho de Odontologia, o GT-Odonto, através da Portaria $\mathrm{n}^{\circ} 191$, de 27 de julho de 1982. A sua finalidade era definir e orientar as ações do Ministério da Saúde no campo da Odontologia e integrar e coordenar as atividades de apoio às Secretarias Estaduais de Saúde. Três

38 Sérgio Pereira graduou-se em Odontologia em Lins, em 1958. Ingressou por concurso, em 1964, na Secretaria de Educação e Cultura do Distrito Federal. Foi um dos criadores do Programa Integrado de Saúde do Escolar (PISE), em setembro de 1977, e coordenou este programa por mais de uma década. (NARVAI, 1995)

39 João Audifax Cesar de Albuquerque graduou-se Odontologia, em 1948, no Distrito Federal (ESCOLAR, 1948), foi coordenador regional de saúde do sul Brasília (DF).

40 Fernando Molinos Pires concluiu a graduação (1964) e mestrado (1974) ambos na Universidade Federal do Rio Grande do Sul (UFRGS) e doutorado em Odontologia pela UFF em 1995. Foi presidente da Associação Brasileira de Saúde Bucal Coletiva (Abrasbuco) na década de 1990. Foi professor titular da UFRGS, de 1967 a 1995. Informações obtidas através do seu currículo lattes.

41 A gestão do ministro dr. Waldir Arcoverde apoiou a formação de grupos técnicos ligados a áreas específicas. (VIANNA, 1988) 
dentistas $^{42}$ foram designados para participar deste grupo de trabalho: Mércio de Azevedo Ferreira, Benedito Elias Waquim e Paula Piratininga, através da Portaria $\mathrm{n}^{\circ} 78$, de 8 de novembro de 1982, a qual também tratava das atribuições do grupo. Coube a Mércio de Azevedo Ferreira a gerência do GT-Odonto e apoiou esta iniciativa, José Alberto Hermógenes de Souza. O grupo ganhou destaque pelo financiamento do Finsocial.

Osdyr Brasileiro Matos, Solón Magalhães Viana e Vitor Gomes Pinto foram designados como assessores do GT, em caráter eventual. Ressalta-se, entretanto, um caráter de informalidade tendo em vista que esse GT não integrava o organograma do Ministério da Saúde. Vianna (1988), que analisou os relatórios do GT-Odonto, aponta que a atuação do grupo esteve mais relacionada a medidas de prevenção, através da fluoretação.

O GT atuou junto ao Instituto Nacional de Alimentação e Nutrição (INAN) e à FSESP, na operacionalização dos sistemas de fluoretação de águas de abastecimento público, que estavam paralisados em 30 localidades, e estenderam a implantação para novos sistemas de abastecimento público de água potável em 35 cidades. Em seguida, atuou no convênio BNDES/BNH/MS com alocação de recursos do Finsocial também na fluoretação das águas, promovendo proteção a quase metade da população brasileira (46\%). O GT-Odonto também atuou no inquérito epidemiológico, nas pesquisas sobre métodos alternativos de fluoretação e no apoio às ações desenvolvidas pelos estados. Os assessores do GT também participaram da formulação do Praod-Conasp, anteriormente tratado no presente estudo.

Em agosto de 1985, o GT-Odonto fez reivindicações sobre a criação da Divisão Nacional de Odontologia Social, com competências semelhantes àquelas elencadas na criação do GT, com quatro serviços: Serviço de Supervisão e Avaliação; Serviço de Programação e Normas Técnicas; Serviço de Epidemiologia; e Serviço de Desenvolvimento dos Recursos Humanos.

Ainda no início do ano de 1985, Vitor Gomes Pinto, no IPEA, Adriano Meireles, presidente do Conselho de Odontologia do Distrito Federal, e Ribamar Azevedo, da Associação Brasileira de Odontologia, conseguiram uma reunião com Tancredo Neves, novo presidente eleito. O encontro foi concedido graças à influência da secretária de Tancredo Neves, que era paciente do dr. Adriano Meireles. Eles elaboraram e entregaram uma proposta de Política de Saúde Bucal, juntamente com Ribamar Azevedo, presidente da ABO, e Swendenberguer Barbosa, presidente do Sindicato dos Odontologistas do Distrito Federal (SODF) e membro do MBRO. (GUERRA, 1985; PAULO, 1985b) O documento caracterizava as graves condições

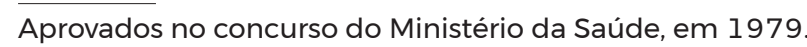


da população brasileira com relação às doenças bucais e sugeria a reestruturação da área odontológica no nível federal, a garantia do acesso a serviços odontológicos, no mínimo, para eliminação da dor e infecção, a formação de recursos auxiliares e sua utilização em práticas adequadas às necessidades da população e a adequação técnico-odontológica para tratamento precoce de grandes contingentes populacionais. No programa emergencial, propunham ampliar o programa de fluoretação das águas de abastecimento público. (FREIRE; BARBOSA, 1985)

No mesmo ano, Vitor Gomes Pinto, Sergio Francisco Piola e Solon Magalhães Vianna, no âmbito do IPEA, formulam um documento intitulado "A Política de saúde na nova república: subsídios para sua formulação”, a partir de estudo desenvolvido pelos mesmos no qual apontam estratégias importantes a serem desenvolvidas pelo Ministério da Saúde no novo governo.

Ainda em 1985, o Conselho Federal de Odontologia, através do seu presidente, reconhece e elogia o aumento do custeio da prestação de serviços odontológicos e afirma confiança devido ao financiamento da Odontologia da Previdência. Ao passo em que estes dentistas festejavam o aumento da verba da previdência (DENTISTAS... 1985), o Ministério da Saúde seguia com financiamento restrito para suas ações e os relatórios finais de eventos científicos apontavam a necessidade de ações de prevenção, conforme já mencionado. (SERAPHIM, 1985)

Entretanto, mesmo em meio ao movimento da Reforma Sanitária, a proposta da política de saúde bucal enfrentou muitas resistências no interior da Secretaria Nacional de Programas Especiais de Saúde (SNEPS)/MS, em 1986. (VIANNA, 1988)

Em 26 de agosto de 1987, é criada a Divisão Nacional de Saúde Bucal pela Portaria no 420, de 24 de agosto de 1987, publicada na seção I do Diário Oficial da União. A Divisão Nacional de Saúde Bucal integrou a Secretaria de Projetos Especiais do Ministério da Saúde.

Era quase que um costume da época. Você tinha os grandes programas no Ministério da Saúde de controle de doenças, malária, esquistossomose, febre amarela e tinha os grandes programas do Ministério. E também a estrutura do Ministério não era tão detalhada como é hoje. [...]dentro dos programas especiais tinha oftalmologia, tinha saúde do escolar e principalmente todos os programas que eram especiais na época. (Entrevistado 12, dentista, escritor)

A DNSB, composta por três serviços (Epidemiologia; Programação e Normas Técnicas; e Recursos Operacionais), passou a fazer parte do organograma do Ministério da Saúde, dentro da Secretaria de Projetos Especiais. As atribuições da DNSB pela portaria eram: 
fornecer subsídios para a definição da Política Nacional de Saúde Bucal; estabelecer diretrizes para o cumprimento desta política, através do programa nacional de saúde bucal, nas atividades de prevenção, manutenção e recuperação, de acordo com as atividades regionais do país; orientar, coordenar, normalizar e supervisionar as atividades da área; fomentar a participação comunitária no acompanhamento e avaliação das ações; incentivar o desenvolvimento de pesquisa e articular-se inter e intra-institucionalmente com órgão do Sistema Nacional de Saúde e do setor privado. (BRASIL, 1987b)

Os técnicos e gestores que estavam no Ministério da Saúde eram do grupo da Saúde Pública da USP e convidaram Vitor Gomes Pinto para ser o diretor da Divisão Nacional de Saúde Bucal. Dominou a DNSB do Ministério da Saúde, a vertente da Odontologia em Saúde Pública oriunda da Faculdade de Saúde Pública (FSP) da USP que se reproduziu nos estudos desenvolvidos e na política. Emergiu, nas entrevistas, a defesa de um grupo técnico que ocupou a gestão da DNSB, sendo contraposto pelo MBRO.

Mesmo tendo sido oficialmente publicado no Diário Oficial da União (DOU), em 6 de agosto de 1987, a reunião do MBRO, de 28 de junho de 1987, citou a criação da Divisão Nacional de Saúde Bucal como uma reivindicação histórica. Contudo, repudiou a forma de sua efetivação, pois colidiria com os princípios da I CNSB quanto aos aspectos ideológicos e organizacionais, tendo em vista que não contemplava a ampla participação dos profissionais e não assegurava o controle, por segmentos organizados da população, na formulação de uma Política Nacional de Saúde Bucal. (BOLETIM INFORMATIVO DO MOVIMENTO BRASILEIRO DE RENOVAÇÃO ODONTOLÓGICA, 1987)

O Boletim no 12 do MBRO, de1987, retrata divergências no seu interior pela súbita criação da DNSB, ao passo que o resumo da assembleia extraordinária aponta a desconsideração da existência de uma coordenação nacional no interior do movimento. Para Serra (1998), a criação do DNSB da maneira que se processou mostrou que o Movimento tinha um discurso para a sociedade "mais voltado para a democratização do que para as questões específicas da categoria”. O boletim do SODF, que tinha membros participando do MBRO, também manifestou seu repúdio à criação da DNSB nos moldes expostos. (ZANETTI, 1993)

A Portaria de criação da DNSB estabelece sua competência:

fornecer subsídios para a definição da Política Nacional de Saúde Bucal; estabelecer diretrizes para o cumprimento desta política, através do pro- 
grama nacional de saúde bucal, nas atividades de prevenção, manutenção e recuperação, de acordo com as atividades regionais do país; orientar, coordenar, normalizar e supervisionar as atividades da área; fomentar a participação comunitária no acompanhamento e avaliação das ações; incentivar o desenvolvimento de pesquisa e articular-se inter e intra-institucionalmente com órgão do Sistema Nacional de Saúde e do setor privado. (BRASIL, 1987b)

A primeira equipe de trabalho da DNSB foi composta por Vitor Gomes Pinto, o diretor; Mércio de Azevedo Ferreira, assessor e substituto do diretor; Benedito Elias Waquim, assessor; Maria Helena Porangaba, assessor; e os secretários Rosa Pimentel e Vaneide Martins. O grupo era misto, o diretor seguia os referenciais da FSP/USP e os assessores tinham formações distintas. Mércio Azevedo, oriundo de Pernambuco, tinha formação em saúde pública, já Benedito Waquim fez residência no Hospital do Câncer, ambos concursados do Ministério da Saúde. Acrescenta-se que outros profissionais trabalharam em outros períodos curtos, como Luiz Carlos Santos e os CD João Antônio Neto Caminha, Sylvio P. Gevaerd, Milton F. A. Silva e Arturo Delano de La Cruz. (ZANETTI, 1993) Em 1988, a DNSB trabalhou sem recurso próprio, dedicou-se: ao estudo da situação da odontologia brasileira, com a publicação do primeiro inquérito nacional em saúde bucal; às diretrizes operacionais da DNSB; à coordenação técnica; e ao apoio aos programas odontológicos dos estados e municípios. (SERRA, 1998; ZANETTI, 1993)

A partir dos resultados do inquérito epidemiológico realizado, a Divisão trabalhou no planejamento para a Política Nacional de Saúde Bucal e, em seguida, para a captação de recursos para o Programa Nacional para Controle da Cárie Dentária (Precad), segundo Pinto (1993) que afirma que o orçamento da União de 1989 continha a particularidade de uma dotação específica para ações de Saúde Bucal, aproximadamente $\mathrm{Cz} \$ 2,2$ milhões ( $\mathrm{R} \$ 15.611,14) .{ }^{43}$

Entretanto, a análise das Leis Orçamentárias Anuais (LOA) do Brasil na gestão de Sarney, de 1985 a 1989, mostra a existência de atividade específica da fluoretação de águas financiada pelo Plano Nacional de Saneamento (Planasa)/BHN, no Ministério do Interior, em 1985, e no Ministério do Desenvolvimento Urbano e Meio Ambiente, nos anos subsequentes. Apesar de existirem ações de saúde do escolar sendo desenvolvidas pelo MEC, estas atividades não constam no detalhamento da LOA. As ações odontológicas desempenhadas pela FSESP estavam em

43 Valor corrigido pelo índice IPCA-A para o ano de 2010, através da calculadora do cidadão do Banco Central do Brasil. 
uma rubrica mais ampla de assistência médica e sanitária ou assistência médica e odontológica, assim como não havia discriminação do orçamento para a saúde bucal no orçamento do MPAS. Neste sentido, o orçamento referente ao ano de 1989 expressa a primeira dotação específica para saúde bucal do Ministério da Saúde.

O orçamento para o exercício financeiro de 1985, continha baixíssima previsão de recursos para a saúde bucal, destinados à Fluoretação no Sistema de Abastecimento de Água (Planasa/BNH), pelo Ministério do Interior, além das ações no Ministério da Saúde, com atividades de assistência médica e sanitária, pela FSESP, que contemplavam a Odontologia. (BRASIL, 1984) Na LOA para o exercício de 1986, as atividades de fluoretação das águas pelo Planasa/BNH estavam a cargo do Ministério do Desenvolvimento Urbano e Meio Ambiente. Quanto à FSESP, uma entidade supervisionada do Ministério da Saúde no Orçamento Federal, constava assistência médica e odontológica e, também, o aumento dos recursos planejados, entretanto, não se individualizaram os gastos com a assistência odontológica ao interior da FSESP (Tabela 1). (BRASIL, 1985)

Na LOA para o ano de 1987, houve redução na previsão de recursos quando comparada ao ano anterior. A rubrica de assistência médica e sanitária continha a assistência médica e odontológica frente à meta de reduzir cárie dental em crianças de 6 a 14 anos. Na mesma rubrica, também estava prevista a redução da morbimortalidade da faixa produtiva da população. Quanto à fluoretação no sistema de abastecimento de água, este orçamento previa a meta de reduzir em $65 \%$ a prevalência da cárie dental da população de 7 a 14 anos de idade, através da fluoretação dos sistemas públicos de abastecimento de água prevista para 16 municípios e uma população beneficiada de 12.300 mil habitantes. (BRASIL, 1986a)

O objetivo da fluoretação permaneceu o mesmo no ano seguinte com aumento das metas: 75.000 ligações domiciliares, 12 sistemas de unidades de fluoretação de sistemas com 651 mil habitantes beneficiados, o que correspondia a menos de $1 \%$ da população brasileira naquele ano. A fluoretação das águas estava alocada no Ministério da Habitação, Urbanismo e Meio Ambiente. Já na FSESP, a meta para saúde bucal permaneceu a de "reduzir a incidência de cárie dental em crianças de 6 a 14 anos” com aumento no número de consultas planejadas. (BRASIL, 1987a) Já no orçamento para o ano de 1989, observou-se a especificação de atividade "Assistência à Saúde Bucal” com o objetivo de reduzir a prevalência dos problemas de saúde bucal. (BRASIL, 1989a) Houve subtração das outras rubricas.

Em 1985, o fina nciamento das ações da FSESP correspondia a 37,9\% do Ministério da Saúde, quando se somam os recursos para assistência com outras ações desenvolvidas por esta Fundação, além dos recursos destinados à sua gestão. 
Entretanto, o percentual total de custeio das ações da FSESP decresce ao longo do tempo, quando se analisa, comparativamente, o orçamento do Ministério da Saúde. No período analisado, ressalta-se a ausência de especificação da assistência odontológica da previdência nos orçamentos.

De 1985 a 1988, não foi possível verificar o percentual de recursos financeiros especificamente para a saúde bucal, na previsão do orçamento da União, tendo em vista que não existia o detalhamento para as ações da FSESP. No ano de 1989, foi possível verificar que se destinou $0,10 \%$ dos recursos do Ministério da Saúde, e $0,002 \%$ do orçamento da União, o que evidencia que as políticas de saúde bucal não eram priorizadas.

Tabela 1 - Distribuição dos recursos alocados para ações de saúde bucal, da função Saúde e Saneamento, do Ministério da Saúde e da União

\begin{tabular}{llllll}
\hline Ano & $\begin{array}{l}\text { Fluoretação das } \\
\text { águas }\end{array}$ & FSESP* & $\begin{array}{l}\text { Assistência } \\
\text { à SB }\end{array}$ & $\begin{array}{l}\text { Ministério da } \\
\text { Saúde }\end{array}$ & União \\
\hline & & & & & \\
1989 & $\mathrm{R} \$ 0,00^{*}$ & $\mathrm{R} \$ 0,00$ & $\mathrm{R} \$ 15.791 .289,80$ & $\mathrm{R} \$ 1.584 .354 .464,98$ & $\mathrm{R} \$ 750.424 .370 .543,54$ \\
& & & & & \\
1988 & $\mathrm{R} \$ 103.959 .186,42$ & $\mathrm{R} \$ 117.794 .298,42$ & $\mathrm{R} \$ 0,00$ & $\mathrm{R} \$ 5.807 .922 .635,91$ & $\mathrm{R} \$ 357.809 .776 .042,16$ \\
1987 & $\mathrm{R} \$ 9.875 .025,14$ & $\mathrm{R} \$ 59.687 .422,64$ & $\mathrm{R} \$ 0,00$ & $\mathrm{R} \$ 4.900 .696 .497,49$ & $\mathrm{R} \$ 210.233 .246 .564,61$ \\
1986 & $\mathrm{R} \$ 25.322 .573,84$ & $\mathrm{R} \$ 112.068 .515,79$ & $\mathrm{R} \$ 0,00$ & $\mathrm{R} \$ 7.658 .367 .367,02$ & $\mathrm{R} \$ 418.719 .798,77$ \\
1985 & $\mathrm{R} \$ 34.946 .008,83$ & $\mathrm{R} \$ 69.494 .699,00$ & $\mathrm{R} \$ 0,00$ & $\mathrm{R} \$ 3.699 .852,38$ & $\mathrm{R} \$ 194.107 .857,20$ \\
\hline
\end{tabular}

* Os valores destinados à FSESP para assistência médica e odontológica, sem os valores de gestão e outras rubricas.

Obs: Não havia especificação para as ações odontológicas na previdência na LOA desses anos.

Valores convertidos para real através da tabela de conversão do Banco Central do Brasil com correção do índice IPCA (IBGE) para fins de aproximação com o cenário atual.

De 1985 a 1988, não foi possível verificar o percentual de recursos financeiros especificamente para a saúde bucal na previsão do orçamento da União, tendo em vista que não existia o detalhamento para as ações da FSESP.

A partir dos valores na moeda Cruzado.

Fonte: adaptado de Brasil (1984, 1985, 1986a, 1987a, 1989a). 


\section{POLÍTICA NACIONAL DE SAÚDE BUCAL (PNSB) DE 1989}

Em outubro de 1988, em Brasília, foi lançado o primeiro documento intitulado Política Nacional de Saúde Bucal, com publicação oficial no ano de 1989 (Figura 4), remetendo a um conceito de Atenção Básica em Saúde Bucal como

O conjunto de ações orientadas à identificação, prevenção e solução dos principais problemas da população afetada, a qual se produz como o fruto da participação consciente e organizada da comunidade e de sua cooperação com as instituições de saúde. (BRASIL, 1988)

Foi, porém, entendido como sinônimo de ações essenciais destinadas ao alívio da dor e controle de infecção em grupos epidemiologicamente prioritários. Embora fosse denominada de Política Nacional de Saúde Bucal, o objetivo principal da política era enfrentar o problema cárie. Assim, o Sistema de Saúde buscaria se organizar para:

- alcançar ampla cobertura das crianças de 6 a 12 anos;

- prevenir as doenças bucais, com ênfase na cárie dental, em toda a população, a partir do nascimento;

- enfatizar ações de educação para a saúde bucal, em todos os níveis;

- prestar cuidados essenciais onde houvesse uma comunidade;

- prestar atenção especializada a casos encaminhados pela rede básica de saúde bucal; e

- expandir, gradativamente, a prestação de serviços resolutivos aos grupos em segundo e terceiro graus de prioridade - 13 a 19 anos e 2 a 5 anos de idade. 
O objetivo geral da política aprovada ${ }^{44}$ pela Portaria no 613/GM, de 13 de junho de 1989, foi "proporcionar melhores níveis de saúde bucal à população brasileira e ampliar o acesso aos serviços odontológicos disponíveis” (BRASIL, 1989b), entretanto, observou-se um objeto de trabalho predominantemente voltado aos dentes e à cárie dentária.

Os objetivos específicos da política tratavam de:

- reduzir em $50 \%$ a prevalência de cárie dental em crianças e adolescentes no prazo de dez anos;

- combater as doenças periodontais, aumentando os índices de higidez em todas as faixas etárias;

- reduzir significativamente os índices de edentulismo e o número de extrações na população jovem e adulta;

- democratizar o acesso aos serviços odontológicos por meio do aumento da oferta, da atenção a grupos prioritários e da ampla participação da comunidade;

- estruturar uma rede nacional de serviços básicos em saúde bucal;

- promover ações continuadas de educação para a saúde bucal, de forma a nortear todas as atividades do setor; e

- apoiar a formação de recursos humanos de nível superior, técnico e auxiliar compatíveis com o quadro epidemiológico, com a situação econômico social e com os padrões de crescimento populacional do país. (BRASIL, 1989b)

Apesar de constar no documento a sua construção pelas entidades de saúde pública e representativas de classe, além das seis Macro-coordenadorias Regionais de Odontologia, fundamentada na experiência adquirida ao longo dos anos e de

44 Na minuta de aprovação do referido documento constam: (i) Vitor Gomes Pinto - diretor da Divisão Nacional de Saúde Bucal (SNPES)/Ministério da Saúde; Osdyr Brasileiro de Matos: coordenador de Supervisão e Auditoria de Odontologia - Inamps/ MPAS; Celso Fetter Hilgert: secretário nacional de Programas Especiais/MS; João José Candido da Silva: coordenador especial de Ciências da Saúde - Secretaria de Ensino Superior/ MEC; Nicolau Tortamano: presidente da ABO; Osmar Soares de Freitas: presidente do CFO; Gregório Abner Cabral: presidente da Federação Nacional de Odontologia; Edrízio Barbosa Pinto: presidente da Associação de Ensino Odontológico; Charlei Fayal de Lira: presidente da Academia Brasileira de Odontologia; Maria Aurinalva Lobão: coordenadora macro-regional de Odontologia do Norte; Tereza Marluce Rocha Tavares: coordenadora macro-regional de Odontologia/Nordeste I; Dorielio Barreto da Costa: coordenador macro-regional de Odontologia/Nordeste II; José Abel Porto Almeida: coordenador macro-regional de Odontologia Centro-Oeste; Urubatã Madeiros Vieira: coordenador macro-regional de Odontologia Sudeste; e Djalmo Sanzi Souza: coordenador macro-regional de Odontologia do Sul. 
um sólido processo de construção democrática, Zanetti (1993) afirma que as prioridades programáticas foram definidas a partir das proposições da VII CNS e não contou com um debate setorial amplo.

A plenária do MBRO, de 28 de janeiro de 1989, tratava que, historicamente, as entidades de classe aprovavam todas as iniciativas dos governos das elites; afirmava ser inaceitável que a tão reclamada política não contasse com a participação dos trabalhadores, estudantes, usuários dos serviços; e acusava a PNSB de tão ilegítima quanto o próprio governo Sarney; ademais, apontavam que o documento ignorava as deliberações da I CNSB. (ZANETTI, 1993)

A formulação foi muito coordenada pelo Vitor Pinto, com uma participação do Sylvio Gevaerd com a discussão com coordenadores de macrorregião. Consulta a essas pessoas, mas ela ficou enquistada no ministério. Ela não teve uma repercussão nacional [...]. (Entrevistado 7, dentista, consultor)

A política era uma reivindicação antiga da categoria, da categoria de saúde pública, dos coordenadores estaduais, municipais, do pessoal que fazia saúde pública na época. O Brasil é pioneiro no mundo ocidental, principalmente nos países em desenvolvimento, nós éramos copiados pela América Latina e pelos outros. (Entrevistado 12, dentista, escritor)

As distintas tomadas de posição sobre a política podem ser analisadas segundo as trajetórias dos agentes. Entrevistado 7 graduou-se em Odontologia, em 1971, concluiu especialização em Odontologia Preventiva e Social, em 1979. Seu pai era dentista e seus avós comerciante e funcionário público. Tinha disposições políticas, sendo filiado a partido político, o PMDB. Entrevistado 12 formou-se em Odontologia em 1965, mestrado em Saúde Pública, em 1977. Seu pai era serventuário da justiça, seu avô materno era jornalista; desconhece a profissão dos avós paternos. Não possuía filiação a partidos políticos, apresentando pequena disposição política. O Entrevistado12 apresentava maior acumulação de capital burocrático e científico que Entrevistado 7, que, por sua vez, apresentava capital burocrático mediano e maior capital político que Entrevistado 12.

Os serviços deveriam se organizar também por prioridades. Os serviços emergenciais eram para todos e deveriam preceder os demais; em segunda prioridade, as ações preventivas e de educação em saúde; em terceiro lugar, "serviços recuperadores básicos” como atenção à cárie e doença periodontal, ao grupo de 6 a 12 anos; em quarta escala estariam as especialidades básicas para atenção endodôntica, periodôntica, protética, cirúrgica e ortodôntica para os grupos de 6 a 12 anos e 13 
a 19 anos participantes de um sistema organizado; e na quinta posição, serviços especializados de maior complexidade. Não ficaram claras as condições utilizadas para a definição dos serviços citados. A coordenação política nacional do setor seria da DNSB com o apoio da Coordenadoria de Supervisão e Auditoria de Odontologia do Inamps. (BRASIL, 1988)

O Entrevistado 12 afirmou que o processo de construção da política exigiu etapas, como a formulação de um documento inicial, assim como recebeu muitas críticas quando estava na DNSB. A política se baseou nos conhecimentos de saúde pública praticados até então, preconizados por Mário Chaves e Alfredo Reis Viegas. Não trazia inovações do ponto de vista científico, tendo se baseado no sistema incremental. Incorporava diretrizes do processo da reforma sanitária, como universalização, participação da comunidade, hierarquização, regionalização e integração institucional, mas não abordava como operacionalizá-la quanto aos problemas sociais construídos relativos a doenças bucais.

Observa-se que o documento da política buscava responder ao inquérito epidemiológico de 1986, que estabelecia como prioridades a cárie e a doença periodontal. Uma comissão assessorava o Diretor da Divisão Nacional de Saúde Bucal do Ministério da Saúde, Vitor Gomes Pinto, que já havia participado da comissão de especialistas para editar o documento anterior no âmbito da Previdência.

O V Enatespo, realizado de 23 a 26 de agosto de 1988, reafirmou o projeto da Reforma Sanitária Brasileira, as conclusões da VIII CNS e da I CNSB. O relatório tratou que as conclusões da I CNSB divergiram da primeira política de saúde bucal.

As críticas perpassaram os seguintes aspectos:

- a plenária final da I CNSB recomendou a criação de um Conselho Nacional de Saúde Bucal com representantes estaduais e municipais para formulação da Política e deliberar sua implementação, sendo que este Conselho não foi formalmente criado;

- advertiu a elaboração de pacotes inadequados às realidades locais;

- defendeu o processo de descentralização pelo fortalecimento da municipalização; e

- criticou as entidades de classe contrárias à extinção do cargo de odontologia do Inamps, explicando que este era um passo para a consolidação do SUDS. (ENATESPO, 1988)

Em 13 de junho de 1989, foi publicada portaria que instituía o grupo de especialistas em prevenção de doenças bucais que era composto por Alfredo Reis Viegas, 
da USP, Osvaldo Carro Buendia, da Secretaria de Estado da Saúde de São Paulo e que trabalhava com o tema flúor, Jaime Aparecido Cury, professor da Universidade de Campinas (Unicamp) e que também desenvolvia trabalhos sobre flúor, Milton Fernando de Andrade Silva, da Universidade Federal de Alagoas (UFAL), Tania Maria Drehmer, da Universidade Federal do Rio Grande do Norte (UFRN), Leo Kriger, da Universidade Federal do Paraná (UFPR), Marisa Maltz, da Universidade Federal do Rio Grande do Sul (UFRGS) e Yvonne Buischi, então presidente da Aboprev.

A maioria dos consultores pertencia ao campo científico, com exceção de Osvaldo Carro Buendia que pertencia ao campo burocrático. Destaca-se que Alfredo Reis Viegas era professor com grande capital simbólico e científico da FSP/USP. Os outros consultores foram convidados pela expertise no campo científico em temas como cariologia, flúor, Odontologia Sanitária e Odontologia Preventiva.

A Aboprev foi objeto de estudo de Soares (2014). A autora abordou que, na década de 1980, a instituição desempenhou papel importante na fundação do espaço da Odontologia Preventiva e Social.

Figura 4 - Capa do documento de publicação da Política Nacional de Saúde Bucal, 1989

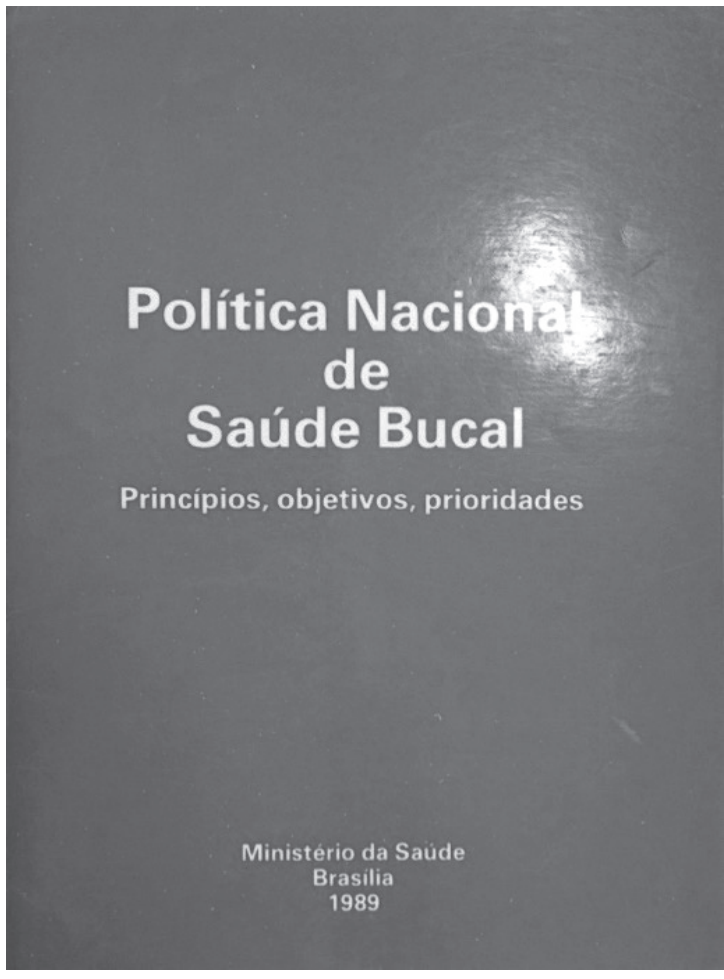

Fonte: Brasil (1989b).45

Cedido pelo Dr. Vitor Gomes Pinto. 
Hamilton Belinni, periodontista e professor da Unicamp, teve o apoio de Alfredo Reis Viegas e de outros colegas de profissão. Bellini agregou alguns dentistas na criação, com o nome inicial de Abrava, ${ }^{46}$ da qual Paulo Capel e Carlos Botazzo também participaram. A Abrava depois passou a se chamar a Aboprev. A prof ${ }^{\text {. }}$ Yvonne Buischi assumiu a presidência da Aboprev, no final da década de 1980, e é considerada por levar as propostas da instituição ao Brasil inteiro. A instituição cresceu por apresentar aspectos da prevenção também no âmbito privado, não apenas na saúde pública. Jaime Cury participou da Diretoria de Normas e Produtos e trouxe muitas contribuições sobre o flúor assim como na formulação das políticas de saúde bucal. A Aboprev organizou vários eventos científicos, criou sua própria revista e consolidou-se no campo científico, o que contribuiu para a sua influência no campo burocrático. (SOARES, 2014)

O Comitê Técnico Científico da Aboprev apoiava o processo decisório da Divisão do MS, a partir do acúmulo de capital científico pelos professores em diversas áreas.

Era o Alfredo Reis Viegas, o Jaime Cury, o Milton Fernando de Alagoas, a Ivone Buischi e Oswaldo Buendía, que era o cara do flúor. Esses estavam sempre nos apoiando. Esses eram a base de conhecimento científico, eram esses e principalmente o Viegas. (Entrevistado 12, dentista, escritor)

O Programa Nacional de Prevenção da Cárie Dental (Precad) (Figura 5), publicado no mesmo ano, tinha como objetivo geral reduzir em dez anos, 50\% da cárie dentária na população brasileira. A proposta era atingir o máximo de pessoas possíveis. Os subprogramas eram:

- fluoretação de água de consumo público;

- uso tópico de fluoretos;

- opção pela adoção de géis fluoretados aplicados em moldeiras na época das campanhas de vacinação, para atingir o máximo de pessoas;

- vigilância e controle - normas para controle e registro de produtos;

- formação de recursos humanos; e

- estudos epidemiológicos e biológicos. 
O Precad foi um desdobramento da primeira política e trazia planos mais detalhados de como combater a cárie dentária na década de 1980. Este programa foi bastante combatido, pois não existiam evidências científicas das melhorias da utilização do flúor em gel em crianças em detrimento das soluções fluoradas. Optou-se pela fluoretação com gel em moldeiras para crianças nas épocas de vacinação. Não houve consenso e o coordenador solicitou a aprovação no intuito de tratar a fluoretação de massas como alternativa semelhante aos mutirões de vacinas.

Zanetti (1993) traz evidências de que o método da fluoretação tópica pelos géis foi fruto da experiência do Serviço Social do Comércio (SESC)/DF com o "Método Carrossel”, que preconizava a fluoretação tópica de flúor gel em massa, através do qual era possível realizar 1.500 aplicações diárias, meta difícil de ser alcançada anteriormente com outros meios.

A citação traz as disputas no espaço. A oposição é entre o técnico e o político. Mas há também a oposição de dentistas do campo científico, consultores que pesquisavam o flúor, assim como alguns dentistas que representavam suas macrorregiões, pertencentes ao campo burocrático, que também foram contrários à utilização do método da fluoretação tópica através de moldeiras.

Figura 5 - Capa do documento de divulgação do Precad, 1989

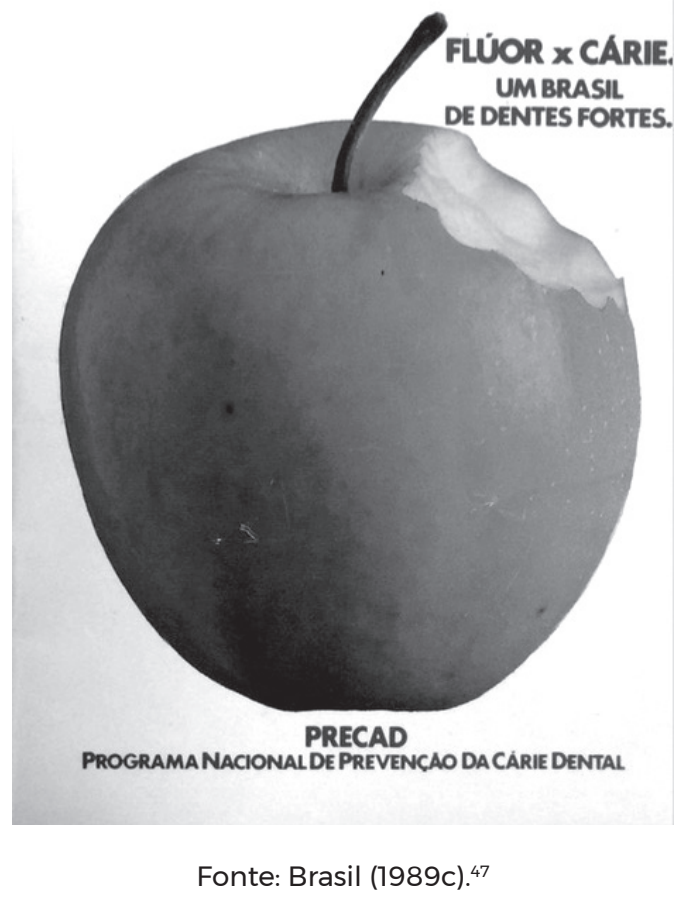

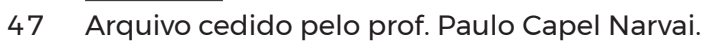


Conforme já citado, em 13 de junho de 1989, foi publicada a Portaria nº 614/ GM que estabeleceu o grupo de especialistas em prevenção de doenças bucais para assessorar a DNSB e apoiar as Unidades Federadas em seus programas, no intuito de reduzir o índice das enfermidades na população brasileira. Poucos dias depois, foi editada a Portaria de $n^{\circ} 616 /$ GM, de 23 de junho de 1989, que tratava da conformação de coordenadorias estaduais para apoio às políticas regionais e participação nas discussões nacionais, mas não definia nomes para compor essas coordenadorias.

Em seguida, em resposta às reivindicações dos movimentos sociais, das associações de classe e aos relatórios finais dos Enatespo, foi criado um comitê consultivo para a política.

\section{Regulamentação específica para fluoretação nos cremes dentais e enxaguatórios}

Outra resposta aos problemas bucais foi a fluoretação dos cremes dentais e, posteriormente, dos enxaguatórios bucais. Após a formação do comitê de especialistas, Jaime Cury, dentista e professor e pesquisador da área de flúor, trabalhou junto à DNSB para regulamentar os teores de flúor nos produtos utilizados pela população. A exemplo de outros países que haviam reduzido cárie, o Brasil também seguiu nesta linha para o combate à carie e o incentivo à prevenção.

Com as novas eleições presidenciais, foi eleito Fernando Collor de Melo como novo presidente da República. Vitor Gomes Pinto, com inserção predominante no campo burocrático, fez um documento ao novo ministro de Saúde, Alcenir Guerra, do novo governo, para permanecer na DNSB baseado em:

- estruturação de uma rede de serviços básicos;

- expansão e consolidação de um programa preventivo; e

- educação em saúde bucal com ênfase na autoproteção. (PINTO, 1990)

O documento datado de 15 de março de 1990 é iniciado com uma breve caracterização dos principais problemas bucais da população brasileira, do quadro de recursos humanos e da situação da rede pública de serviços. (PINTO, 1990)

A mãe do novo presidente tinha um dentista do qual era muito amiga e tinha relação de proximidade entre as famílias, Sergio Weyne que se tornou o novo coordenador de Saúde Bucal do Brasil, a partir de 1991. 


\section{O espaço de formulação e crítica das políticas de saúde bucal}

O espaço de formulação das políticas de saúde bucal, no período do final da década de 1980, foi formado pelos dentistas que participaram do processo de escrita, discussão e aprovação da política, mas, também, por aqueles que se organizavam para a realização de críticas que influenciavam a resposta do Estado. $\mathrm{O}$ principal problema construído nesse processo foi a doença cárie, a despeito da denominação "saúde bucal".

Estava em jogo quais seriam as melhores estratégias para o controle da cárie, o papel da DNSB, as práticas do cirurgião dentista, o mercado de trabalho, os interesses liberais, a formação profissional, pessoal auxiliar, estratégias de combate à cárie e a inserção da Odontologia na reestruturação do Sistema de Saúde do Brasil. A conformação deste espaço incluía agentes com inserção em distintos campos sociais. A Política Nacional de Saúde Bucal, de 1989, foi motivada pelas críticas à ausência de uma "política nacional de Odontologia" (ESTÁ..., 1982, p. 5) e teve início na convergência de interesses e trajetórias de agentes do campo burocrático com o apoio daqueles do campo científico vinculados à Faculdade de Saúde Pública da USP.

O espaço de formulação da política correspondia a uma intersecção dos campos político, científico e burocrático. As inserções predominantes dos $\mathrm{CD}$ desse espaço eram vinculadas ao campo burocrático, seguido dos consultores, que apresentavam inserção no campo científico. O diretor da DNSB possuía mestrado, mas seguia carreira com inserção predominante no campo burocrático. Dentre aqueles que participavam da gestão da DNSB ou desempenhavam papel como consultores da Divisão, a maioria apresentava baixo capital político, sem filiação a partidos políticos no momento, mas atuantes em associações corporativas (Quadros 7, 8 e 9). Os consultores se destacavam pelo capital científico e sua inserção neste campo, entretanto, existiam aqueles com inserção no campo burocrático, também (Quadros 7 e 8).

Os cirurgiões-dentistas que criticavam as políticas de saúde bucal através de movimentos organizados como o MBRO e os Enatespo, atuavam no campo burocrático, em esferas estaduais ou municipais, mas também existiam aqueles que pertenciam ao campo científico. A maioria deles era vinculada a partidos políticos de esquerda, figurava dentre os agentes com maior capital político e militavam em instituições pela Reforma Sanitária Brasileira, como o Cebes. Sua maior interseção com o espaço da política de saúde bucal se deu através do campo político, naquele momento. O polo dominante era exercido por agentes inseridos no campo burocrático, principalmente por profissionais oriundos da FSP/USP, assim como alguns consultores. 
O ponto de vista das instituições e das entidades de classe foi analisado a partir das tomadas de posições de seus participantes, mas representado enquanto microcosmo da instituição composta por seus agentes como a ABO e o CFO que apresentavam tomadas de posição relacionadas à Odontologia Liberal.

A ruptura com os interesses liberais e de mercado e as práticas odontológicas vigentes conformou um subespaço contra hegemônico de agentes identificados e partícipes do processo da Reforma Sanitária Brasileira.

As maiores acumulações de capital estiveram relacionadas à gestão da DNSB, aos consultores ligados à Aboprev e à FSP/USP. Dois membros que participavam dos Enatespo e MBRO também apresentavam grande volume de capital, um deles com trajetória no campo científico e o outro no campo burocrático estadual. Ambos tinham grande acumulação de capital político. Os outros membros desses movimentos apresentavam baixo ou médio volume de capital global.

Os agentes que influenciaram a formulação das políticas de saúde bucal ao final da década de 1980 eram predominantemente homens, de 25 a 60 anos no período. Há diferenças geracionais dentre as distintas posições ocupadas. Os representantes das entidades de classe, os membros do IPEA, a direção da DNSB e alguns consultores que realmente influenciaram o desenho da política, como Alfredo Reis Viegas, pertenciam a duas gerações de sanitaristas ligados à Odontologia Sanitária/Social.

Em geração intermediária, encontram-se alguns consultores, principalmente vinculados à Aboprev, assim como alguns membros do MBRO, fundadores do movimento. Ademais, os mais jovens pertenciam a esse subespaço de crítica.

O documento foi construído no interior do campo burocrático com o apoio de alguns consultores. Não houve consenso pela aprovação da política no grupo de consultores, segundo os entrevistados. As entidades de classe, como o CFO e a $\mathrm{ABO}$, se opuseram, inicialmente, à aprovação da política, devido às críticas à inclusão de pessoal auxiliar. A vertente dominante da Odontologia Sanitária defendia o uso do pessoal auxiliar, por sua vez extremamente combatida pelas entidades de classe que acreditavam representar uma ameaça aos postos de trabalho e ao papel do cirurgião-dentista no país. Já o MBRO acusava a DNSB de ilegítima assim como apontava a inconformidade da política com as deliberações da I CNSB.

Os dentistas com inserção no campo burocrático possuíam pós-graduação, mestrado ou especialização, em Saúde Pública. Os consultores apresentaram capital escolar alto, muitos deles com doutorado. Já dentre os membros do MBRO, a distribuição do capital escolar foi distinta, mas predominaram os agentes com especialização em Saúde Pública pela USP. 


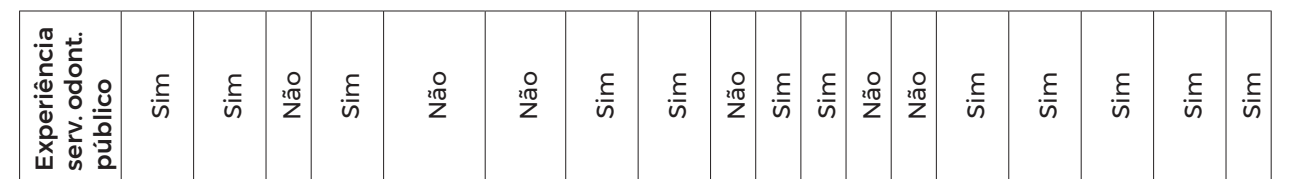

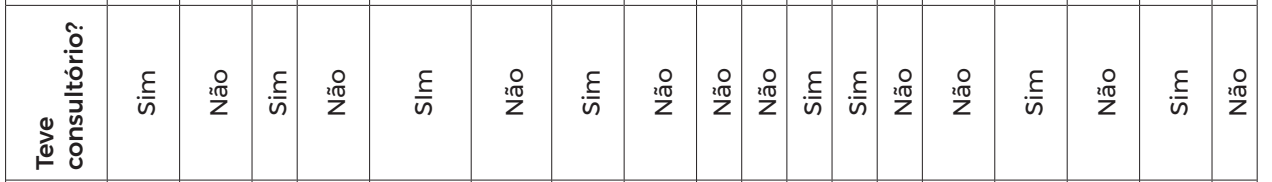

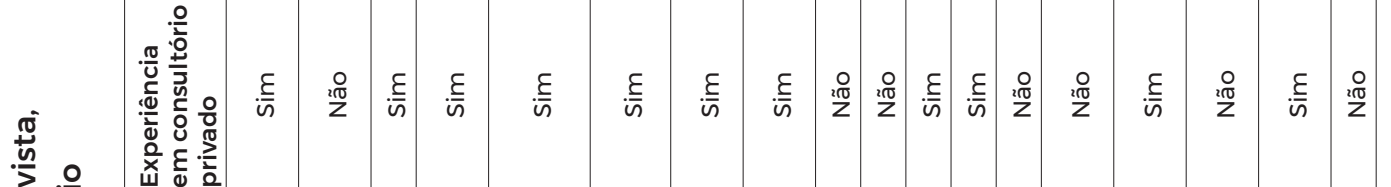

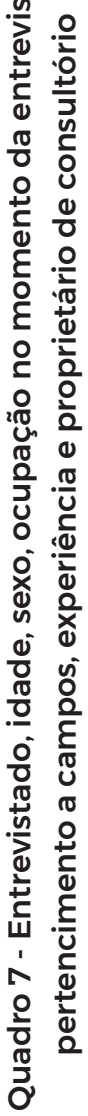

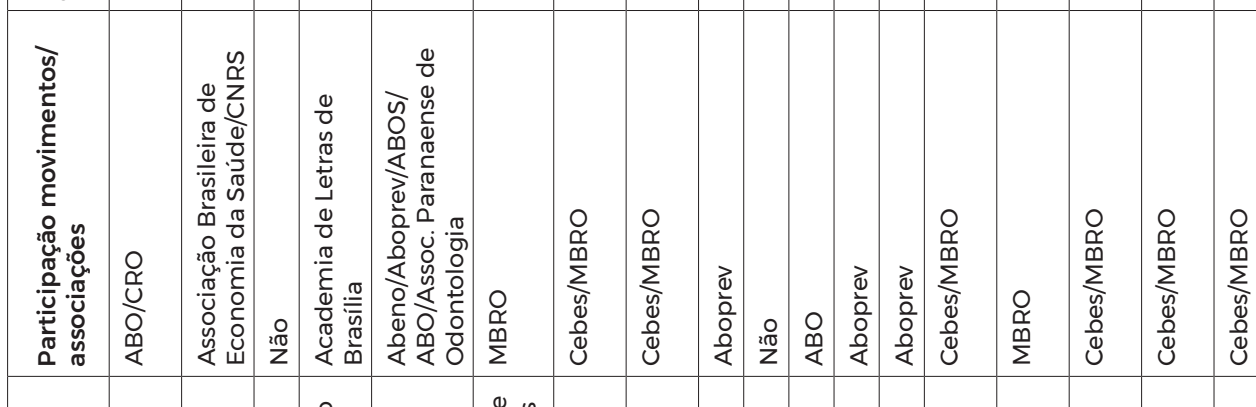

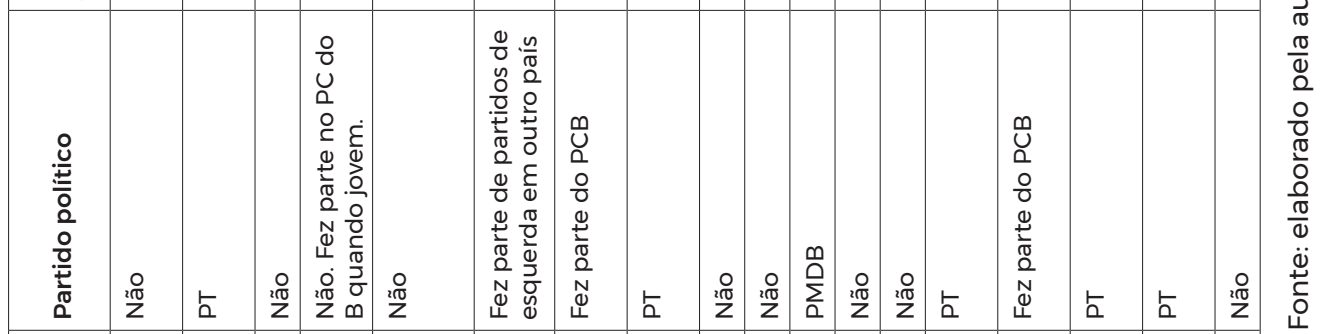

\begin{tabular}{|c|c|c|c|c|c|c|c|c|c|c|c|c|c|c|c|c|c|c|}
\hline 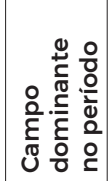 & 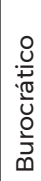 & 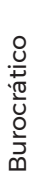 & 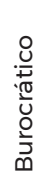 & 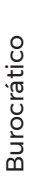 & 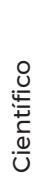 & 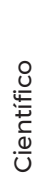 & 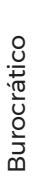 & 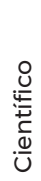 & 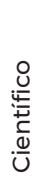 & 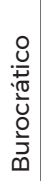 & 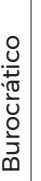 & 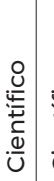 & 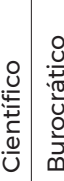 & 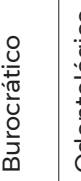 & $\begin{array}{l}\frac{8}{0} \\
\frac{0}{0} \\
\frac{0}{0} \\
\frac{0}{0} \\
0\end{array}$ & 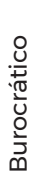 & 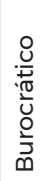 & 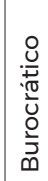 \\
\hline
\end{tabular}

\begin{tabular}{|c|c|c|c|c|c|c|c|c|c|c|c|c|c|c|c|c|c|}
\hline 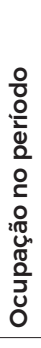 & 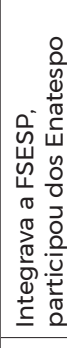 & 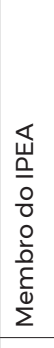 & 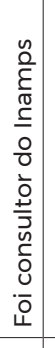 & 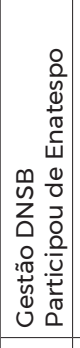 & 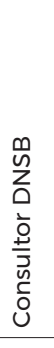 & 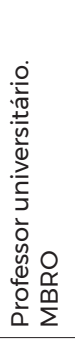 & 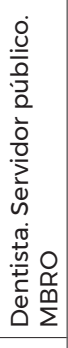 & 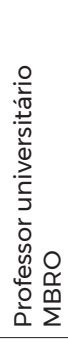 & 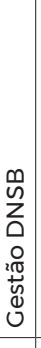 & 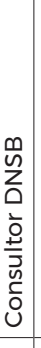 & ' & 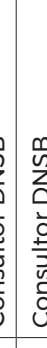 & 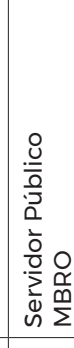 & 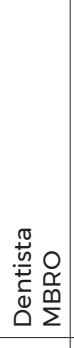 & 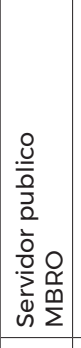 & 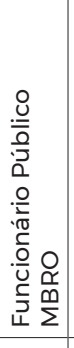 & 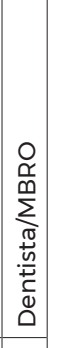 \\
\hline 㸚 & $\begin{array}{l}\dot{u} \\
\dot{\omega} \\
\Sigma\end{array}$ & $\begin{array}{l}\dot{u} \\
\stackrel{\tilde{\sigma}}{\Sigma} \\
\end{array}$ & $\begin{array}{l}\dot{u} \\
\dot{\sigma} \\
\Sigma\end{array}$ & $\begin{array}{l}\dot{u} \\
\sum^{\pi} \\
\Sigma\end{array}$ & $\begin{array}{l}\dot{U} \\
\text { J } \\
\text { IJ }\end{array}$ & $\begin{array}{l}\dot{u} \\
\stackrel{\sigma}{\pi} \\
\Sigma\end{array}$ & $\begin{array}{l}\dot{u} \\
\stackrel{w}{\tilde{\sigma}}\end{array}$ & $\begin{array}{l}\dot{u} \\
\dot{\omega} \\
\dot{\pi}\end{array}$ & $\begin{array}{l}\dot{U} \\
\stackrel{u}{2} \\
\Sigma\end{array}$ & $\begin{array}{l}\dot{u} \\
\Sigma \\
\Sigma \\
\Sigma\end{array}$ & 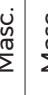 & 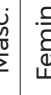 & $\begin{array}{l}\dot{u} \\
\stackrel{\sigma}{\Sigma} \\
\Sigma\end{array}$ & $\begin{array}{l}\dot{u} \\
\stackrel{\tilde{m}}{\Sigma}\end{array}$ & $\begin{array}{l}\dot{u} \\
\sum^{\pi} \\
\Sigma\end{array}$ & 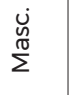 & $\begin{array}{l}\dot{\dot{m}} \\
\dot{m}\end{array}$ \\
\hline 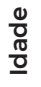 & ৪ & $\bar{\infty}$ & $\stackrel{0}{\sim}$ & $\stackrel{ \pm}{\Sigma}$ & $\stackrel{M}{x}$ & $\kappa$ & 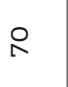 & 8 & \begin{tabular}{c}
$\infty$ \\
$\bullet$ \\
\hdashline
\end{tabular} & 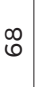 & 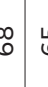 & $\begin{array}{lll}0 \\
0\end{array}$ & $\overline{6}$ & $\stackrel{\infty}{\circ}$ & นก & 员 & \\
\hline 岀 & $\bar{v}$ & $\stackrel{\bullet}{N}$ & $N$ & $\stackrel{N}{ }$ & $\stackrel{\Omega}{\square}$ & $N$ & M & $\stackrel{\infty}{ }$ & 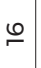 & - & 0 & $\triangle$ & $\stackrel{\circ}{ }$ & $\stackrel{N}{N}$ & $\stackrel{n}{\leftarrow}$ & $\stackrel{\sim}{N}$ & \\
\hline
\end{tabular}


Quadro 8 - Entrevistado, segundo distribuição e volume dos capitais científico, político e burocrático, década de 1980*

\begin{tabular}{|c|c|c|c|c|c|c|c|c|c|c|c|c|c|}
\hline & \multicolumn{4}{|c|}{ Capital Científico } & \multicolumn{4}{|c|}{ Capital Político } & \multicolumn{4}{|c|}{ Capital Burocrático } & \multirow[t]{2}{*}{$\begin{array}{c}\text { Volume } \\
\text { Total }\end{array}$} \\
\hline & $\uparrow$ & $\uparrow \uparrow$ & $\uparrow \uparrow \uparrow$ & $\uparrow \uparrow \uparrow \uparrow$ & $\uparrow$ & $\uparrow \uparrow$ & $\uparrow \uparrow \uparrow$ & $\uparrow \uparrow \uparrow \uparrow$ & $\uparrow$ & $\uparrow \uparrow$ & $\uparrow \uparrow \uparrow$ & $\uparrow \uparrow \uparrow \uparrow$ & \\
\hline E13 & & & & & & & & & & & & & 2 \\
\hline E21 & & & & & & & & & & & & & 2 \\
\hline E16 & & & & & & & & & & & & & 3 \\
\hline E26 & & & & & & & & & & & & & 3 \\
\hline E2 & & & & & & & & & & & & & 4 \\
\hline E19 & & & & & & & & & & & & & 4 \\
\hline E23 & & & & & & & & & & & & & 4 \\
\hline E7 & & & & & & & & & & & & & 5 \\
\hline E2O & & & & & & & & & & & & & 5 \\
\hline $\mathrm{E} 1$ & & & & & & & & & & & & & 6 \\
\hline E3 & & & & & & & & & & & & & 6 \\
\hline E4 & & & & & & & & & & & & & 6 \\
\hline E9 & & & & & & & & & & & & & 6 \\
\hline E10 & & & & & & & & & & & & & 6 \\
\hline E12 & & & & & & & & & & & & & 6 \\
\hline E15 & & & & & & & & & & & & & 6 \\
\hline E22 & & & & & & & & & & & & & 6 \\
\hline E18 & & & & & & & & & & & & & 8 \\
\hline
\end{tabular}

*Legenda: Muito Alto $\uparrow \uparrow \uparrow \uparrow$; Alto $\uparrow \uparrow \uparrow$, Médio $\uparrow \uparrow$, Baixo $\uparrow$, Muito baixo.

Fonte: elaborado pela autora.

O grupo apresentou trajetória ascendente, em sua maioria, tendo cursado o ensino médio em colégios públicos (Quadro 9). No sociograma elaborado em função do capital político e da posição dos agentes na arquitetura do espaço, através de suas tomadas de posição, pode-se observar: na esquerda, encontram-se os indivíduos que defendiam uma posição à época consistente com o projeto da Reforma Sanitária Brasileira, do SUS democrático e de crítica à prática odontológica vigente. À direita, estão posicionados os dentistas que ocupavam cargos nos CFO e ABO e tomavam posições ligadas à defesa da Odontologia liberal, contrárias à proposta da inserção de pessoal auxiliar e apoio às políticas de saúde que poderiam representar benefício aos profissionais da Odontologia (Figura 9).

No centro do sociograma, na posição do governo, estão os coordenadores de Odontologia do Inamps e o diretor da DNSB do Ministério da Saúde com tomadas de posição relacionadas à Odontologia Sanitária/Social, além do trabalho dos técnicos e assessores, que estão situados mais à direita ou à esquerda, a depender de suas tomadas de posição e do capital político acumulado. 


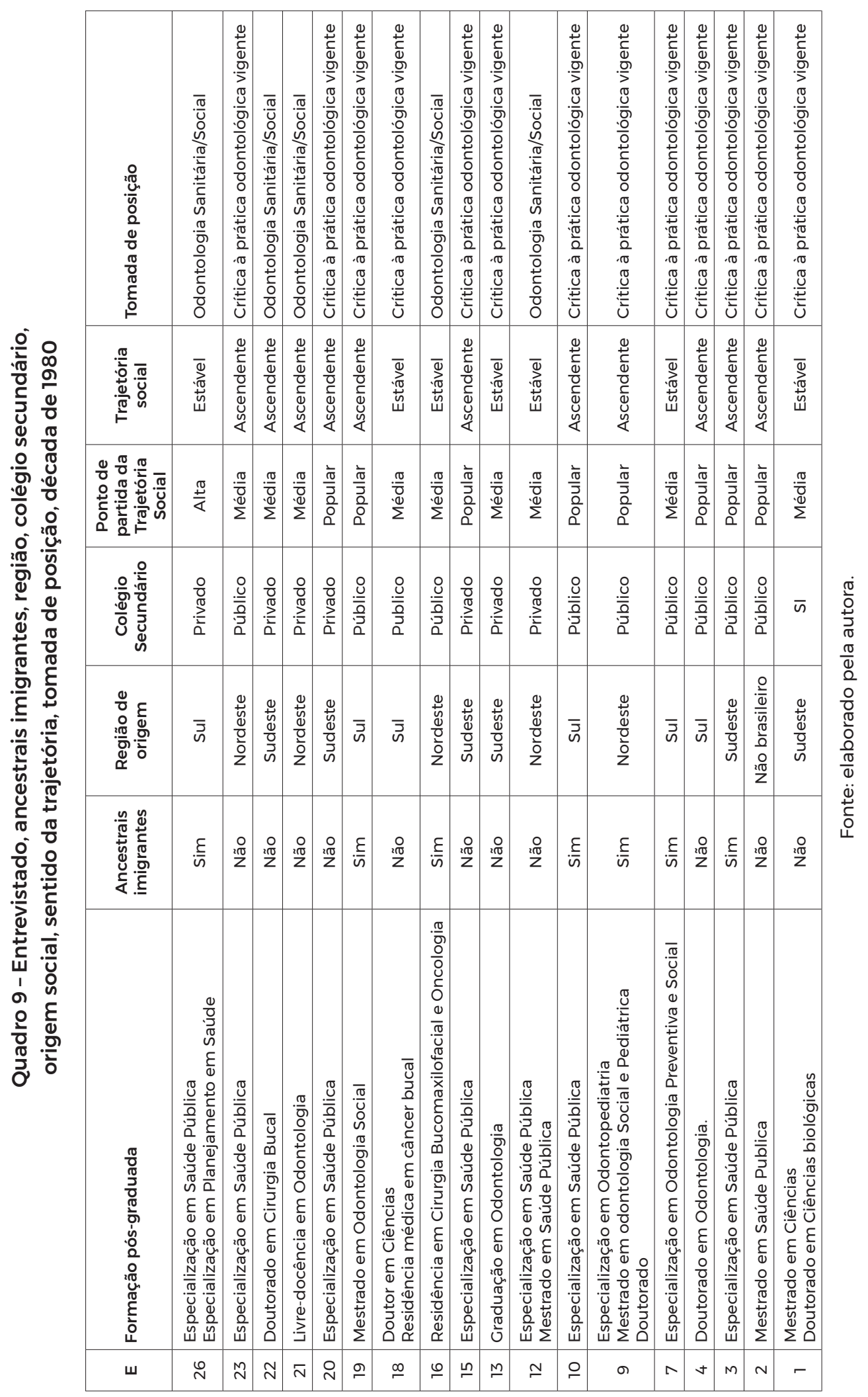


Embora haja uma variada combinação das três espécies de capital analisadas, pode-se dizer que a posição da Aboprev é mais relacionada ao alto capital científico, enquanto a da DNSB com a acumulação de capital burocrático e o do MBRO a um elevado capital político (Figuras 6, 7 e 8). Destaca-se que a palavra mais frequente de quatro e cinco letras foi "saúde", estando "bucal” em segundo plano (Figura 10), o que pode ser justificado pelo cenário sociopolítico econômico no qual se lutava pela democracia e pela saúde, estando a saúde bucal incluída nas políticas de saúde.

Alguns autores como: Chaves (1986), Pires (2004), Narvai e Frazão (2008b), Moysés e Goes (2010) e Moysés (2014), analisaram o conceito do termo saúde bucal. Chaves (1986) considera que este conceito é uma abstração útil. O autor relaciona a utilização do termo para efeitos práticos, significando saúde parcial (bucal), servindo para identificar objetivos parciais em programas de saúde. Justificou a utilização do termo em seu livro Odontologia social, em substituição de saúde dentária, devido ao reconhecimento da responsabilidade do dentista, àquela época, de ir além dos dentes, contemplando as estruturas adjacentes que os suportam e certas porções da cavidade bucal. Reiterou que a saúde bucal em estado de harmonia, normalidade ou higidez da boca só teria significado quando acompanhada da saúde geral do indivíduo assim como os programas especializados quando integrados em um programa global de saúde pública. Aqui, observa-se uma restrição do objeto da saúde bucal aos dentes, suas estruturas de suporte e partes da boca. É possível observar, também, a utilização do termo saúde oral em publicações, inclusive aquelas do MBRO. Destaca-se que o mesmo texto descrito foi utilizado para conceituar "saúde oral" no livro Odontologia Sanitária, do mesmo autor, em 1960. Nesse sentido, houve apenas uma mudança dos termos "oral” para "bucal”, significando exatamente o mesmo, sem explicitação dos motivos que conduziram a esta mudança.

As Conferências Nacionais de Saúde também abordaram o conceito de saúde bucal, mas de modo abrangente, enquanto parte inseparável da saúde geral do indivíduo, relacionando-se às condições de moradia, alimentação, trabalho, renda, meio ambiente, transporte, lazer, liberdade, acesso e posse de terra, acesso aos serviços de saúde e à informação. (BRASIL, 1986b) Outro trabalho confrontou a definição de Chaves (1986), afirmando que

[...] saúde bucal corresponde a um conjunto de condições objetivas (biológicas) e subjetivas (psicológicas), que possibilitam ao ser humano exercer funções como mastigação, deglutição e fonação e, também, pela dimensão estética inerente à região anatômica, exercitar a autoestima e relacionar-se socialmente sem inibição ou constrangimento. Estas condições devem corresponder à ausência de doença ativa em níveis tais que permitam ao 
indivíduo exercer as mencionadas funções do modo que lhe pareça adequado e lhe permita sentir-se bem, contribuindo desta forma para sua saúde geral. (NARVAI; FRAZÃO, 2008b, p. 18)

Os autores ampliam o conceito de saúde bucal relacionando-o não apenas a estruturas anatômicas, mas a condições também subjetivas, às funções desempenhadas em sua vida e à relação com o sentir-se bem. Ressalta-se, também, que bem-estar é o termo utilizado pela Organização Mundial de Saúde (OMS) para tratar de saúde bucal enquanto parte da saúde geral, essencial para o bem-estar das pessoas. (NARVAI; FRAZÃO, 2008b) Outro trabalho ratifica esse ponto de vista, afirmando que adotar este ideário significa ultrapassar o pensamento hegemônico sobre saúde/doença bucal que advém da visão etiopatogênica e epidemiológica negativa, baseada no diagnóstico normativo das doenças, em suas manifestações clínicas enquanto sequelas terminais.(MOYSÉS; GOES, 2010) Esses autores também analisaram a utilização do termo relacionando-o às práticas de controle social assim como à organização dos serviços públicos, dentre outros. Já Pires (2004) utilizou o conceito de saúde bucal da I CNSB para analisar a Política Brasil Sorridente.

A palavra mais frequente com seis letras ou mais, sete ou mais até dez letras, foi "Odontologia", que apresenta diversas adjetivações e movimentos teóricos que a caracterizam. (NARVAI, 1994) Tendo em vista que os objetivos das diversas políticas analisadas até os anos 1990 priorizaram o controle da cárie dental, há uma dissociação entre o discurso e as práticas.

Figura 6 - Agentes participantes do espaço de formulação de crítica das políticas de saúde bucal, segundo capitais burocrático e científico, década de 1980

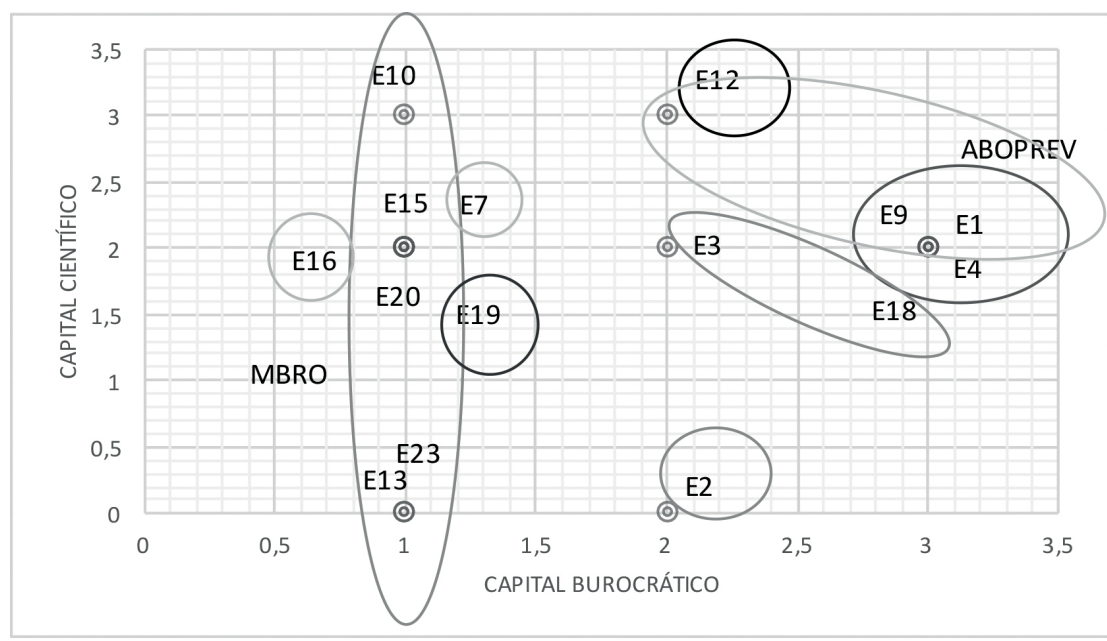

Fonte: elaborada pela autora. 
Figura 7 - Agentes participantes do espaço de formulação de crítica das políticas de saúde bucal, segundo capitais burocrático e político, década de 1980

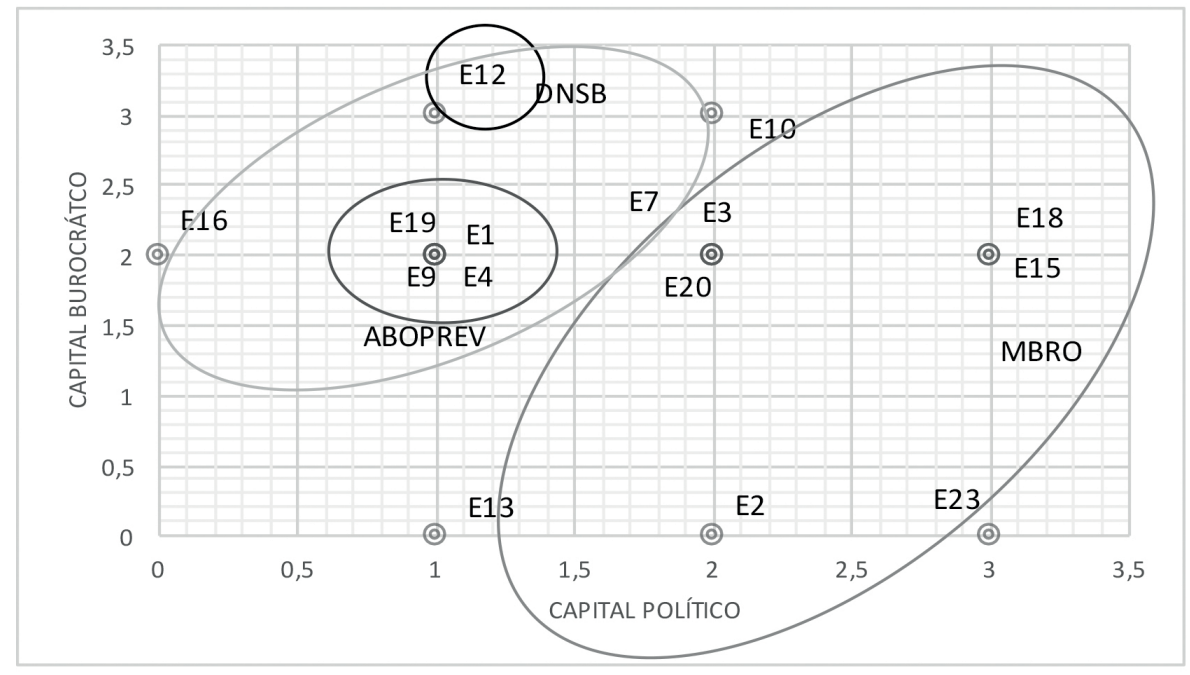

Fonte: elaborada pela autora.

Figura 8 - Agentes participantes do espaço de formulação de crítica das políticas de saúde bucal, segundo capitais político e científico, década de 1980

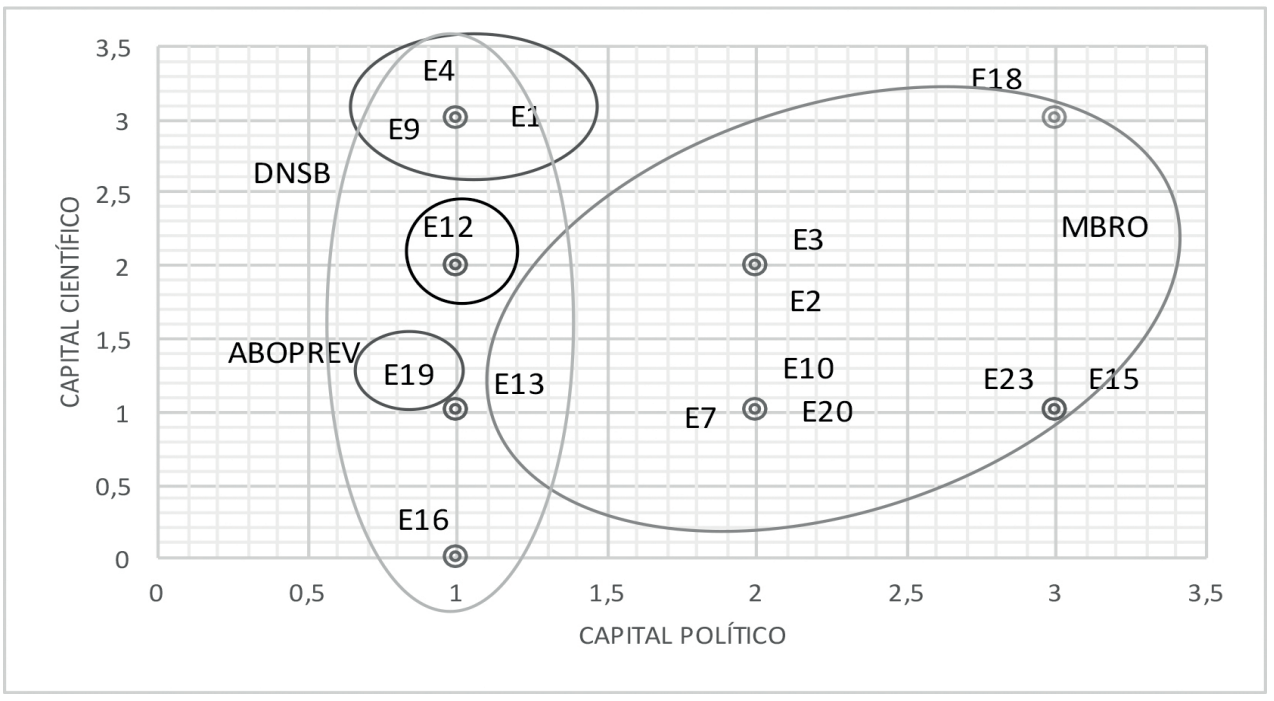

Fonte: elaborada pela autora. 


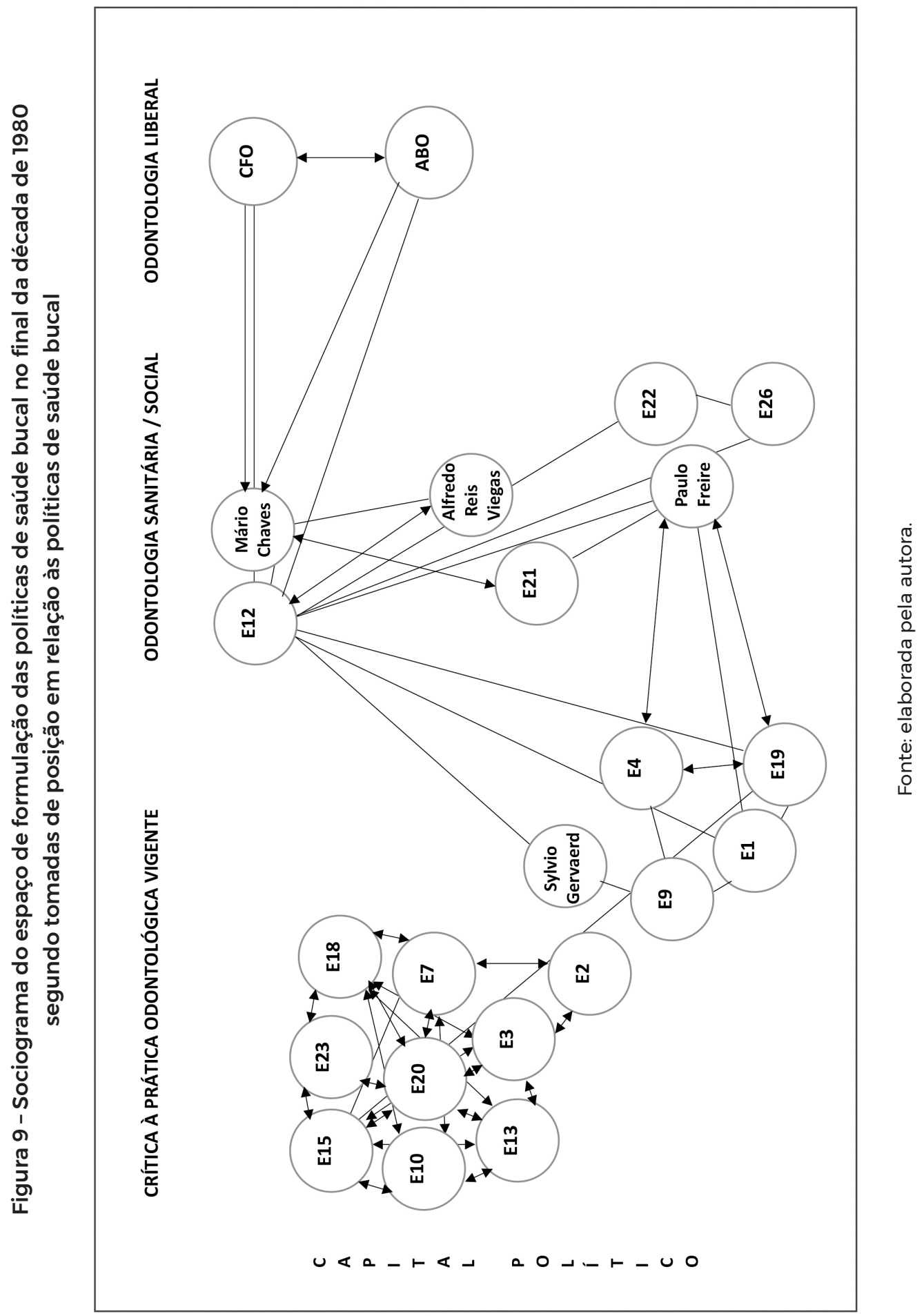

Produção Social da Políticas de Saúde Bucal no Brasil / 109 
Figura 10 - Palavras mais frequentes a partir de cinco, seis, sete, oito, nove e onze letras, respectivamente
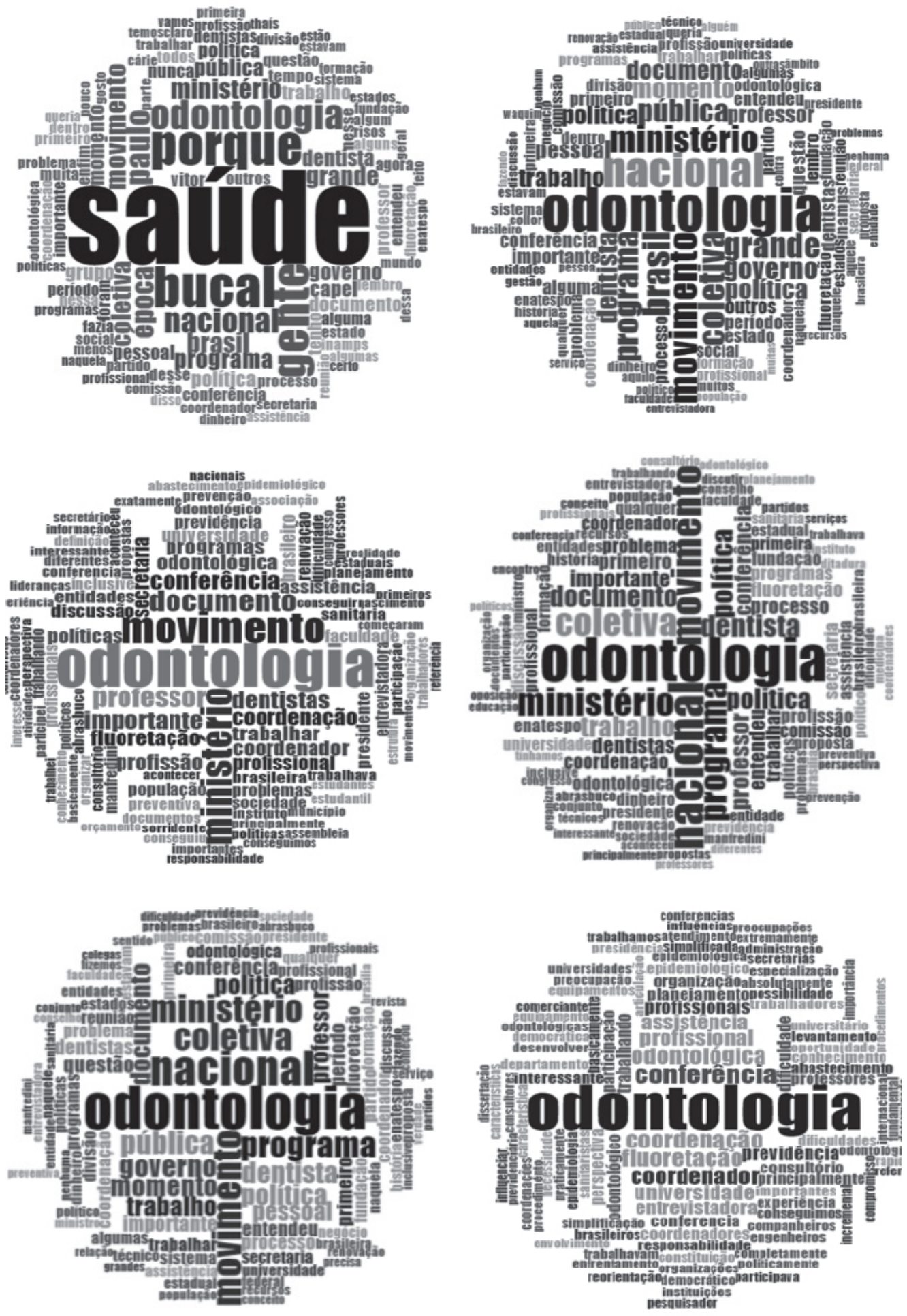

Fonte: elaborado pela autora. 


\section{MUDANÇAS NA TABELA SIA/SUS E PROCEDIMENTOS COLETIVOS}

O plano quinquenal de saúde 1990-1995, divulgado no governo Collor, continha metas discretas para a saúde bucal voltadas apenas para o câncer de orofaringe, cárie e doença periodontal. Para o câncer de orofaringe, as ações se voltavam para a capacitação de recursos humanos, aquisição de equipamentos para as unidades de referência e ações de educação em saúde. Quanto à cárie e doença periodontal, para as metas de redução dos índices da doença cárie, foram planejadas as atividades de fluoretação de $100 \%$ das águas de abastecimento público, a garantia de fluoretos tópicos e práticas de higiene oral para todas as crianças em idade escolar, equipar ou reequipar os serviços odontológicos da rede pública, promover o estudo da fluoretação do sal humano, até 31 de dezembro de 1990.

No início da década de 1990, continuaram a ser firmados convênios entre a DNSB e os estados, ainda na gestão de Vitor Gomes Pinto, ${ }^{48}$ a exemplo dos convênios com os estados de Minas Gerais e Paraná. O convênio ${ }^{49}$ celebrado com a Companhia de Abastecimento de Minas Gerais visava a fluoretação dos sistemas de abastecimento de água para redução da cárie dentária, publicado no Diário Oficial da União, de 10 de janeiro de 1990. (BRASIL, 1990c) Já o Termo que tinha como objetivo reduzir os níveis da incidência de cárie dental da população do estado do Paraná foi celebrado com a Secretaria Estadual de Saúde daquele estado (BRASIL, 1990d), publicado em 1 de fevereiro de 1990, no Diário Oficial da União (DOU).

Alguns meses após, foi publicada a exoneração de Vitor Gomes Pinto, em 7 de maio de 1990 (BRASIL, 1990b), no Diário Oficial da União, pelas razões já explici-

48 Vitor Gomes Pinto graduou-se em Odontologia, em 1965, pela UFRGS, fez especialização em Saúde Pública (1973) na USP, mestrado (1977) e doutorado (1992) em Saúde Pública pela USP. Foi técnico do IPEA e diretor da DNSB do Ministério da Saúde, de 1989 a 1990.

Proc. MS/Da n²5000.011825/89. 
tadas no capítulo anterior. Em seu lugar, foi designado, interinamente, na DNSB, o dentista Mércio de Azevedo Ferreira, ${ }^{50}$ participante do GT-Odonto do Ministério da Saúde e integrante enquanto técnico da DNSB. Sérgio de Carvalho Weyne ${ }^{51}$ era amigo da família Collor e foi convidado pela mãe do ex-presidente para exercer o cargo de diretor da DNSB.

Assim, Weyne foi nomeado chefe de Divisão através da Portaria Ministerial $n^{0}$ 555, de 3 de maio de 1990. Um colega de profissão que assessorava Sérgio Weyne considerou sua habilidade e articulação política assim como o cenário político de grandes limitações para o setor saúde.

Os rearranjos no campo burocrático envolveram a criação de dois grupos técnicos no interior da DNSB, um de "Promoção e Prevenção em Saúde Bucal" e outro sobre “Organização de Serviços em Saúde Bucal”. (CARVALHO et al., 2009)

O grupo de Organização dos Serviços de Saúde atuou na formulação da resposta do Estado através dos Procedimentos Coletivos (PC), tendo sido composta por dentistas com experiência na gestão de saúde bucal: Djalmo Sanzi Souza, ${ }^{52}$ do Rio Grande do Sul, José Paulo Gouveia de Toledo, ${ }^{53}$ de São Paulo e Sylvio Gevaerd, ${ }^{54}$ do Paraná. (CARVALHO et al., 2009; WEYNE, 1999) Rui Oppermann, presidente da Aboprev na gestão de 1991 a 1993 e Jaime Aparecido Cury, diretor da referida Associação, também prestaram assessoria à DNSB no período. Benedito Elias Waquim e Mércio de Azevedo Ferreira continuaram como técnicos da DNSB. (WEYNE, 1999)

Assim, dois dentistas que compuseram a nova gestão haviam participado do Comitê Técnico Científico conformado no final da década de 1980, vinculados à Aboprev, além de Djalmo Souza, que havia participado como coordenador de macrorregião na política anterior e nesta se tornava consultor. Outros profissionais eram vinculados à gestão estadual e municipal de saúde bucal com participação no

50 Mércio de Azevedo Ferreira era cirurgião dentista concursado pelo Ministério da Saúde, integrou o GT-Odonto e a Divisão Nacional de Saúde Bucal como técnico, tendo assumido a gestão em alguns momentos.

51 Sérgio de Carvalho Weyne é cirurgião-dentista, formado em 1961, pela UFF. Microbiologista, ele fez especialização em Bioquímica, em 1966, pela mesma, especialização em Odontologia Preventiva, em 1975, pela Indiana University/USA e doutorado em Clínica Odontológica pela Universidade Federal do Rio de Janeiro (UFRJ), em 2004. Professor da UFF, de 1964 a 1992. Foi diretor da Aboprev, de 1995 a 1997.

52 Djalmo Sanzi Souza possui graduação em Odontologia (1971) e especialização em Odontologia Preventiva e Social (1979), ambas pela UFRGS, e mestrado em Saúde Coletiva (2003) pela Universidade Luterana do Brasil (ULBRA). Foi coordenador de saúde bucal da SES do Rio Grande do Sul.

53 Luiz Paulo Gouveia de Toledo é cirurgião dentista, integrou a coordenação nacional do MBRO, de janeiro a julho de 1989, foi coordenador de Saúde Bucal do estado de São Paulo.

54 Sylvio Gevaerd era cirurgião-dentista, mestre em Odontologia. Foi coordenador de Saúde Bucal do município de Curitiba (PR). 
MBRO e nos Encontros Nacionais, além dos sanitaristas concursados do Ministério da Saúde, que já vinham integrando a DNSB e também participavam dos Enatespo.

A proposta do grupo técnico era a formulação de uma nova política para o país voltada para a implantação através das Secretarias Estaduais de Saúde, tendo em vista que o processo de municipalização da saúde no país ainda não havia se consolidado totalmente. (CARVALHO et al., 2009) Um dos assessores da DNSB à época ressaltou que a proposta se enquadrava melhor para os locais mais avançados na municipalização, a exemplo de Curitiba (PR).

No que se refere aos movimentos contra hegemônicos, o relatório final do VII Enatespo, realizado de 27 a 30 de agosto de 1990, destacava que reconhecia a DNSB como instância política normativa e não executiva necessária à formulação de diretrizes nacionais a serem adequadas às realidades locais.

O relatório, abordou, ainda, que a política nacional deveria ser definida e implementada a partir de um colegiado com representantes dos estados e municípios. A DNSB deveria também cumprir o papel de instância articuladora e facilitadora das ações descentralizadas bem como assessorar, informar e difundir a educação para a saúde bucal. (ENATESPO, 1990) Outra recomendação foi posicionar a PNSB, que deveria ser baseada na Odontologia integral, privilegiando a manutenção e a promoção da Saúde Bucal e buscando a redução e o controle das doenças bucais, junto às demais políticas de saúde e políticas socioeconômicas do governo, a fim de garantir sua efetivação e o repasse de verbas, consolidando a municipalização. (ENATESPO, 1990)

Soares (2014) estudou o surgimento da Aboprev e a consolidação do espaço da Odontologia Preventiva e Social (OPS) no Brasil..55

A autora apontou que a criação da Aboprev foi um marco para a criação deste espaço, que sofreu influência das publicações dos países escandinavos sobre a etiologia da doença periodontal e cárie. (SOARES, 2014) Dois dos assessores da DNSB eram o presidente e um dos diretores da Aboprev, conforme já citado, assim como o próprio Sérgio Weyne se tornou o diretor da Associação no mandato posterior ao de Rui Oppermann.

Ressalta-se a existência de uma Política de Saúde Bucal criada em 1989 e um Programa para sua operacionalização, o Precad, quando a nova gestão da DNSB

55 A Odontologia Preventiva e Social é um movimento considerado como contra hegemônico, relacionado com a Medicina Preventiva. Começa a ganhar força no Brasil na década de 1970 e influencia na criação dos Departamentos de Odontologia Preventiva e Social no Brasil. O movimento foi baseado nos estudos de cariologia e doença periodontal realizados nos países escandinavos. (SOARES, 2014) 
assumiu. Quais motivos levaram à descontinuidade da Política e Programa então vigentes? Quais as bases teóricas para a formulação da nova política?

As diferentes tomadas de posição teóricas influenciaram cursos diferentes das políticas de saúde bucal no Brasil. Enquanto o Precad era a expressão do conhecimento da Saúde Pública tradicional, difundido, principalmente, pela FSP/USP, baseada nas técnicas preventivas de massa, o novo grupo seguia os estudos escandinavos baseados em uma nova concepção do processo de lesão cariosa como multifatorial, oriunda de um processo de desmineralização e remineralizarão, fundamentados na microbiologia e bioquímica. Ademais, segundo os entrevistados, as propostas de fluoretação tópica, através da utilização de moldeiras proposta pelo Programa, tinha ação semelhante à escovação com dentifrício fluoretado, como a experiência dos Estados Unidos.

A concepção da cárie como devastadora e como um fenômeno sem controle ou de difícil solução, conforme analisado na década de 1980, era combatida pela Aboprev. Weyne defendia a cárie como uma doença multifatorial. ${ }^{55}$ Segundo o Entrevistado 9, o flúor teria grande importância em seu controle, mas não poderia ser encarado como "a solução para todos os problemas", pois não seria capaz de interferir em todos os fatores e acrescentou que "se for a solução de todos problemas o Rio de Janeiro por exemplo tem água fluoretada e praticamente todo mundo usa creme dental com flúor e tem atividade cariosa e lesão cariosa”.

Em publicação da Aboprev, Weyne (1999) apontou que a formação em Odontologia preconizava que o cirurgião-dentista deveria aguardar o aparecimento de danos na dentição para iniciar o chamado tratamento curativo. Esta prática acarretava o aparecimento de novas lesões, muitas vezes enquanto o profissional ainda desempenhava sua prática restauradora em outros dentes. O profissional que se deparava, rotineiramente, com situações como essas, substituía o material restaurador anterior por outros em cavidades mais extensas, o que acarretava maior perda de substância dental. Muitas vezes, o destino daquelas unidades dentárias resultava na extração, o que o autor chamou de círculo vicioso do paradigma cirúrgico-restaurador no qual a alternativa passava a ser a reabilitação através de próteses dentárias. Assim, o autor defendia que a atenção odontológica baseada exclusivamente nos procedimentos operatórios não seria capaz de controlar as doenças bucais nem de evitar a perda dental e condenaria o dentista a ser um "fiscal de demolição" dos dentes de seus pacientes.

No mesmo trabalho, Weyne (1999) criticou o critério de Tratamento Completado (TC) utilizado nos serviços públicos brasileiros para crianças e adolescentes, através do qual o usuário recebia "alta” do tratamento odontológico após o término 
do tratamento restaurador. O autor argumentou que as restaurações não tinham a capacidade miraculosa de controlar, por si próprias, as condições "intra e extrabucais que modulam a atividade cariosa”.

A prática previdenciária também reforçava o sistema incremental, através do TC, a exemplo das Ações Integradas em Saúde (AIS). (WERNECK, 1994) Na faixa etária de adultos, o número de extrações era de, aproximadamente, 35 milhões de dentes extraídos/ano por estimativa do Ministério da Saúde, sendo que este procedimento se encontrava dentre aqueles melhor remunerados pelo SUS até 1992. (WEYNE, 1999) Assim, apesar de um discurso voltado para a prevenção por correntes do campo científico, a prática reforçava o procedimento extração. Segundo o mesmo, a alternativa encontrada, na tentativa de reverter o quadro, foi reduzir o valor do procedimento na tabela de custeio do SUS. Um grande aliado do diretor da DNSB, no período, era Ricardo Akel, médico, que ocupava o cargo de secretário nacional de Assistência à Saúde e de presidente do Inamps. (CARVALHO et al., 2009; WEYNE, 1999)

Uma questão que mexia muito comigo é que eu fui ver as estatísticas do Ministério da Saúde e vi que o evento que era mais contemplado no atendimento era extração. Eu me lembro que eu fui conversar com o Secretário Nacional, depois com o Ministro e eu fiz uma frase assim: - Nós temos uma máquina de fazer desdentados no Ministério da Saúde e eu não quero ser o maquinista. Eu acho que a gente tem de alguma forma modificar isso, e uma forma que me ocorre agora é baixar o valor de extração que era o procedimento mais bem pago. [...] Eu pedi ao Secretário Nacional e eu confirmei o que eu suspeitava, então tinha lá o procedimento mais bem pago era extração, então a primeira proposta foi diminuir e foi aceito. ${ }^{56}$

O Programa Odontológico Escolar de Saúde (Proesa), que serviu de inspiração para a nova política da DNSB ${ }^{57}$ (CARVALHO et al., 2009), foi um programa desenvolvido na Secretaria Municipal de Saúde de Porto Alegre, em meados da década de 1980, liderado por Ruy Oppermann, que se baseava na definição de grupos prioritários de escolares a partir do risco biológico para a cárie dentária e buscava reduzir e controlar a cárie através da "fluorterapia intensiva". (CARVALHO et al., 2009)

Na publicação de 1999, Weyne afirmou que uma das propostas mais coerentes para começar a reduzir o "homicídio odontológico" e alterar a "filosofia do 
tratamento" se materializou com a mudança da tabela de financiamento do SIA/ SUS para procedimentos odontológicos e com a formulação da política dos procedimentos coletivos. Em entrevista Weyne diz que:

Não existem formas de as pessoas fazerem procedimentos preventivos por uma razão muito simples, porque eles não são pagos. Então vamos criar um conjunto de práticas que nós chamamos de procedimentos coletivos e que vai se incluir o pagamento por aplicação tópica de flúor no consultório, compra de creme dental com flúor, compra de escova. Eu falei com os ministros: - vocês têm vacina em medicina, nós não temos vacina em Odontologia e uma das coisas que não é vacina, mas que se aproxima um pouco é que as crianças e a população tenham acesso a escova de dente e creme dental. Fizemos um levantamento e a população era muito carente de escova e creme dental. Então [...] entrou uma portaria que se instituía os procedimentos coletivos, foi a primeira vez que isso apareceu e eles eram pagos e todas as pessoas que tivessem inscrição no atendimento do SUS fariam jus o recebimento de uma escova de $3 \mathrm{em} 3$ meses e um tubo de creme dental com flúor a cada mês ou 2 tubos a cada 3 meses [...] defendi meu caso, o Ministro não queria assinar, o Secretário não queria assinar, foram convencidos a assinar, eles assinaram a portaria está aí [...].

Assim, em 9 de outubro de 1991 foi publicada a Portaria $n^{\circ} 184$, assinada pelo secretário nacional, Ricardo Akel, que criou três tipos de procedimentos coletivos em saúde bucal. A Portaria, que anunciava entrar em vigência a partir de $1^{\circ}$ de janeiro de 1992, era justificada pela mudança do modelo de atenção odontológica no país e para a reversão da situação de saúde bucal no país assim como pela necessidade de compatibilizar o financiamento das ações com o novo modelo proposto. (BRASIL, 1991d)

A Tabela publicada na referida data tratava de procedimentos individuais e coletivos. O subgrupo dos procedimentos coletivos (PC) foi dividido em três componentes e cada um destes fixava um valor do programa por "cliente" por mês. O PC I era constituído pelo "conjunto de procedimentos de promoção e prevenção em saúde bucal, de baixa complexidade, dispensando equipamentos odontológicos, desenvolvidos integralmente em grupos populacionais previamente identificados" e fixava o valor de Cr\$520 (R $\$ 1,81)^{58}$ programa/cliente/mês, sendo com-

58 Valores convertidos de Cruzeiro para Real, com deflação pelo IPCA (IBCE), a partir de calculadora disponibilizada pelo Banco Central do Brasil. 
posto por exame epidemiológico, ${ }^{59}$ educação em saúde, ${ }^{60}$ bochechos fluorados ${ }^{61}$ e higiene bucal supervisionada. ${ }^{62}$ Este é o primeiro registro em política de cunho nacional da utilização da escovação supervisionada. Já a fluoretação tópica era utilizada desde o sistema incremental. O PC II consistia em todos os procedimentos do PC I acrescidos de exame clínico para diagnóstico, terapia intensiva com flúor no valor de Cr\$780 (R \$2,71) programa/cliente/mês. Já o PC III contemplava todos os procedimentos do PC I e do PC II acrescidos de remoção de cálculo e polimento dentário, escariação e selamento de cavidade com cimento provisório, aplicação de selantes, remoção de raízes residuais, aplicação de cariostático, correspondendo ao valor de $\mathrm{Cr} \$ 900(\mathrm{R} \$ 3,13)$.

Werneck (1994) aponta que os PC são uma iniciativa da gestão nacional para implementar procedimentos preventivos de abrangência coletiva, entretanto, estes também pressupõem atividades cirúrgicas básicas, como remoção de focos residuais e restaurações provisórias que fazem parte da adequação do meio bucal para outros tratamentos individuais.

O subgrupo dos procedimentos individuais iniciava sua descrição com o exame clínico e era composto por um elenco de ações em componentes denominados Odontologia Preventiva (I, II, III, IV e V); Dentística (I e II); Endodontia e Odontologia Cirúrgica (I e II).

No componente Odontologia Preventiva I constava apenas a Higiene Bucal Supervisionada; já na Odontologia Preventiva II, a aplicação tópica de flúor por indivíduo, selante e cariostático por dente, além de coleta de material para citologia esfoliativa. Os procedimentos de Periodontia como raspagem alisamento e polimento dentário, assim como curetagem subgengival, compunham a Odontologia Preventiva (OP) III e IV, respectivamente. Na OP V, constavam procedimentos de ortodontia e pediatria. Nos componentes de Dentística existiam restaurações de amálgama, resina e também a pino. As exodontias de dentes decíduos e permanentes assim como as múltiplas e de raízes residuais compuseram o bloco da Odonto-

59 Realizado anualmente para verificar as modificações no quadro epidemiológico das doenças bucais no grupo atendido. (BRASIL, 1991d)

60 Atividades educativas realizadas em periodicidade trimestral, enfatizando os cuidados com a saúde bucal.

61 Realizados semanalmente durante todo o ano com soluções de fluoreto de sódio a 0,2\%, sendo, no mínimo, 25 aplicações.

62 Evidenciação de placa bacteriana e escovação supervisionada com pasta fluoretada, realizadas, no mínimo, a cada três meses, ao longo do ano, fornecendo a cada participante uma escova de dentes e um tubo de pasta fluoretada de 90 ou 100 gramas, a cada três meses. (BRASIL, 1991d) 
logia cirúrgica. Já na Endodontia observa-se a possibilidade de pulpotomia e tratamento para dentes uni, bi ou trirradiculares, entretanto, não previa retratamentos.

Em 24 de dezembro do mesmo ano, foi publicada a Portaria $n^{\circ} 198$, que tornou sem efeito a Portaria $n^{0} 184$ que fora publicada anteriormente. A justificativa perpassou a adequação dos códigos aos procedimentos afins e o ajuste às especialidades de Cirurgia e Prótese bucomaxilofacial. O início da vigência é mantido para 1 de janeiro de 1992. Não existiram mudanças relativas aos Procedimentos Coletivos e quanto aos componentes de Odontologia Preventiva e Dentística dos subcomponentes Procedimentos Individuais quando comparados à Portaria anterior, entretanto, os valores foram reajustados para os PC e Procedimentos Individuais (PI). Os PC tiveram mudança em seus valores: PC I - Cr\$676,00 (R\$2,90); PC II Cr\$1.014,00 (R\$4.36) e PC III - Cr\$1.170,00 (R\$5.03). O percentual de aumento foi de $30 \%$ para todos os PC.

Foram acrescentados procedimentos de Estomatologia, Cirurgia Periodontal, Cirurgia bucomaxilofacial de nível ambulatorial e hospitalar e Prótese bucomaxilofacial, incluindo aquelas intraorais, faciais, complementares das radioterapias, além da manutenção periódica destas próteses. A anestesia geral em tratamento odontológico também foi incluída e a Odontologia Cirúrgica (I, II e III) passou a integrar o componente Endodontia. Ressalta-se que o valor das exodontias dos dentes decíduos (Cr\$1.512,00 - R\$6.50) e extrações simples de dentes permanentes eram próximos dos PC III.

Ao analisar o período de 1988 a 1991 quanto ao custeio dos procedimentos odontológicos de 1988 a 1989, pela Previdência, e dos anos 1990 e 1991, pelo Ministério da Saúde, observa-se uma mudança na distribuição dos valores na tabela de 1991. A extração de dentes decíduos se equiparou com as extrações simples sendo que, nos anos anteriores, seu valor era inferior àquele das extrações em dentes permanentes. $\mathrm{O}$ valor atribuído ao exame odontológico era praticamente o mesmo que se atribuía às extrações, entretanto, na tabela de 1991, há uma redução proporcional no valor deste procedimento. Há, também, uma redução da proporção entre os valores de aplicação tópica de flúor, entretanto, o valor do PC III correspondia a $77,4 \%$ do valor relacionado à extração.

A tabela sofreu ajustes quanto ao conteúdo, com a Portaria ${ }^{\circ} 298$, de 16 de junho de 1992, publicada no DOU em 19 de junho de 1992 (BRASIL, 1992d), que retirava o exame epidemiológico do PC I, enquadrando-o no PC II.

A nova tabela do Sistema de Informações Ambulatoriais do SUS contemplava ações educativas coletivas assim como a produção de ações odontológicas no nível individual, mas com uma indução para que o atendimento clínico também con- 
templasse as ações de prevenção (CARVALHO et al., 2009), além daquelas ações de recuperação e reabilitação que já constavam da tabela da Previdência Social e do Ministério da Saúde em 1990.

O grupo técnico assessor que conduzia a implantação da nova política pretendia desenvolver os PC em municípios pilotos e, após essa fase, capacitar dentistas de estados e municípios com os membros da Aboprev. Entretanto, a exoneração do ministro Alcenir Guerra por acusação de compras irregulares impediu o planejamento inicial. (CARVALHO et al., 2009)

A FIO, através de seu presidente Swendenberg Barbosa, em audiência com o presidente do Inamps, em 12 de maio de 1992, contestou a forma de pagamento por produtividade que vinha sendo adotada pelo Inamps. O fato seguia a lógica do setor privado, gerando concorrência entre os profissionais, além de possibilitar a corrupção. (AUDIÊNCIA..., 1992) O presidente da Federação também foi eleito pelas entidades odontológicas para compor o Conselho Nacional de Saúde na categoria profissionais. (FIO..., 1992a)

O MBRO se mostrava desarticulado e um dos seus últimos boletins, em 1990, conclamava participantes a ingressarem no Movimento, abordando que o seu papel até então tinha sido de catalisar, estimular e aglutinar ideias de renovação. O boletim também abordava a pauta de pessoal auxiliar. (BOLETIM INFORMATIVO NACIONAL DO MOVIMENTO BRASILEIRO DE RENOVAÇÃO, 1990)

O relatório final do VIII ENATESPO (1991) também repudiou o pagamento de serviços por produção, "imposto" pelo Ministério da Saúde/Inamps aos municípios e estados. Afirmava que "a pretensão tutelar do Ministério da Saúde é inaceitável”, exigia o repasse de verbas segundo critérios demográficos, criticava a exclusão de grupos não prioritários, como adultos e crianças de zero a três anos, e reiterava, ainda, a necessidade de integração das ações de saúde bucal nas práticas coletivas de saúde e o resgate da integralidade dessas práticas.

Em jornais de grande circulação, críticas gerais às condições de saúde bucal da população eram destacadas. Gilberto Alfredo Pucca Júnior, dentista, diretor do Centro de Referência em Saúde do Trabalhador e coordenador de Saúde Bucal do distrito de Sé da prefeitura municipal de São Paulo, publicou duas matérias, "A tragédia da saúde bucal no Brasil” e "A saúde bucal no Brasil”, ambas no jornal Folha de São Paulo, no ano de 1992, que tratavam de financiamento e da necessidade de superação da dicotomia cura x prevenção, destacando os resultados de estudos da OMS segundo os quais, aos 20 anos, os brasileiros já possuíam 19 dentes cariados. 
Tabela 2 - Valor dos procedimentos odontológicos e razão entre estes e as extrações dentárias de 1988 a 1991, Brasil**

\begin{tabular}{cccccccccccc}
\hline & $\begin{array}{c}\text { Extração } \\
\text { de dente } \\
\text { permanente }\end{array}$ & \multicolumn{2}{c}{$\begin{array}{c}\text { Extração de dente } \\
\text { decíduo }\end{array}$} & \multicolumn{2}{c}{$\begin{array}{c}\text { Exame } \\
\text { odontológico }\end{array}$} & $\begin{array}{c}\text { Aplicação tópica } \\
\text { de flúor }\end{array}$ & PC III \\
\hline Ano & Valor & Valor & Razão* & Valor & Razão* & Valor & Razão* & Valor & Razão* \\
\hline 1991 & $\mathrm{R} \$ 6,50$ & $\mathrm{R} \$ 6,50$ & 1,00 & $\mathrm{R} \$ 2,90$ & 0,45 & $\mathrm{R} \$ 3,12$ & 0,48 & $\mathrm{R} \$ 5,03$ & 0,77 \\
1990 & $\mathrm{R} \$ 15,24$ & $\mathrm{R} \$ 12,57$ & 0,82 & $\mathrm{R} \$ 14,37$ & 0,94 & $\mathrm{R} \$ 9,74$ & 0,64 & $\mathrm{NSA}^{* *}$ & $\mathrm{NSA}^{* *}$ \\
1989 & $\mathrm{R} \$ 13,20$ & $\mathrm{R} \$ 10,89$ & 0,82 & $\mathrm{R} \$ 12,45$ & 0,94 & $\mathrm{R} \$ 1,28$ & 0,64 & $\mathrm{NSA}^{* *}$ & $\mathrm{NSA}^{* *}$ \\
1988 & $\mathrm{R} \$ 73,57$ & $\mathrm{R} \$ 60,77$ & 0,83 & $\mathrm{R} \$ 70,21$ & 0,95 & $\mathrm{R} \$ 47,33$ & 0,64 & $\mathrm{NSA}^{* *}$ & $\mathrm{NSA}^{* *}$ \\
\hline
\end{tabular}

* A razão foi calculada em função do valor de extração de dentes permanentes com alveoloplastia nos períodos de 1988 a 1991 e extração simples de dentes permanentes em 1991, em função da mudança na nomenclatura dos procedimentos na tabela de custeio do SIA/SUS. Todas as moedas foram convertidas para Real com correção do IPCA - IBGE para fins de comparação.

** Não se aplica pois não existia o PC III nos anos anteriores a 1991.

Fonte: elaborado pela autora.

Werneck (1994) destacou a importância, através da indução federal, de um modelo assistencial com maior ênfase em trabalhos preventivos e fundamentados em base epidemiológica mais sólida. Outros autores, como Carvalho e colaboradores (2009), corroboram que houve um impulso para que as ações de prevenção e promoção da saúde alcançassem muitos municípios brasileiros tendo em vista o processo crescente de municipalização da saúde, além de ter contribuído para alterar o modelo de prática odontológica no setor público, direcionando-o para ações preventivas e de promoção da saúde.

Lemos (2002) estudou a expansão dos investimentos e a cobertura dos PC, tendo concluído que os estados que mais investiram foram Mato Grosso, Mato Grosso do Sul, Minas Gerais e Santa Catarina, sendo que o maior percentual médio de coberturas na população alvo ocorreu no Mato Grosso do Sul e em Santa Catarina. Ressaltou, ainda, a incompatibilidade do pagamento por ato em medidas coletivas, que não deveriam ser avaliadas em base individual, mas apontou grande importância dos Procedimentos nas estratégias públicas de combate à cárie dental com alocação de recursos consideráveis, apesar da baixa cobertura populacional em muitos estados e no Distrito Federal.

Werneck (1994) enfatizou que o maior efeito da nova política, em um Sistema de Saúde cujo modelo é definido pela tabela de custeio, foi permitir que os municípios organizassem seus programas de acordo com o que preconizam o PC I e o PC II, além de aumentar a arrecadação mensal, o que poderia ser investido em equipa- 
mentos, instrumentais, recursos humanos, dentre outros. O autor exemplifica com o caso de Belo Horizonte (MG) onde a implantação do PC II no Programa de Saúde Bucal passou a representar $30 \%$ de toda a arrecadação da Secretaria Municipal de Saúde, em 1993.

Críticas foram realizadas quanto ao termo "procedimento coletivo", tendo em vista que o PC não representava apenas um procedimento. (CARVALHO et al., 2009) era um termo do campo médico destinado a ações clínicas de cunho individual. O PC é constituído por um conjunto de ações e o fato de igualar atos distintos criava dificuldades nos registros para mensuração e avaliação do trabalho prestado, o que comprometia a própria credibilidade do registro. (CARVALHO et al., 2009) Ademais, militantes do MBRO também faziam críticas à nova política tendo em vista que existia um foco no fenômeno biológico em detrimento dos determinantes sociais e das mudanças no processo de trabalho, entretanto, não foram detalhadas alternativas para uma nova formulação da política.

Mas naquela altura, em 1991 [...] era um programa odontológico que caiu no gosto de todo mundo, não tem conflito, não tem determinante social, não tem que resolver nada com relação ao processo de trabalho, ratifica teorias odontológicas placogênicas [relacionadas à placa bacteriana], bacteriana e de açúcar, essa coisa toda de açúcar e tal que dá a ideia de que a sociedade tem que ser orientada, ensinada, monitorada, vigiada tal, porque ela édeletéria, ela tem hábitos deletérios, né? Ela come açúcar feito uma besta, ela não se escova e vamos que vamos. Então, como era um programa odontológico, um programa controlista, ideologicamente entra, coincide com o ponto de vista dos departamentos de odontologia social, todos, com a odontopediatria, e está mantido até hoje porque ele está no gosto da molecada. É uma coisa que todo mundo gosta. [...]. (Entrevistado 3, dentista, professor universitário) 


\section{FLUORETAÇÃO DO SAL DE COZINHA E MOVIMENTO ANTI-FLÚOR}

No início de 1990, conforme ressaltado anteriormente, em virtude do novo governo federal recém-eleito, ocorreu uma reorganização dos Ministérios, sendo que a DNSB passou a integrar a Secretaria Nacional de Assistência à Saúde que ficou responsável, dentre outras funções, por:

[...] elaborar e promover a execução de programas nacionais noscampos de saúde materno-infantil, saúde bucal, saúde mental, nutrição, doenças crônico-degenerativas, sangue e hemoderivados, assistência à pneumologia e dermatologia sanitárias, doenças sexualmente transmissíveis e aids. (BRASIL, 1990a)

Analisando-se as tomadas de posição, a Aboprev divulgava amplamente sua adesão e opção pelo método de fluoretação das águas, informando que o flúor na água pode prevenir cárie em todas as idades. A matéria "Água com flúor previne cáries em todas as idades" publicada no jornal Folha de São Paulo, de 29 de janeiro de 1990, tratou também dos mecanismos da ação do flúor na prevenção da cárie dentária.

Países como a Suíça (desde 1955), Colômbia (desde 1965), Hungria (desde 1966-1972), Colômbia (desde 1972), Áustria (desde 1982), Guatemala (desde 1986), Costa Rica (desde 1987), Jamaica (desde 1987), Peru (desde 1990) e Uruguai (desde 1990) apresentavam experiências exitosas do uso do sal fluoretado como medida sistêmica de combate à cárie, segundo a OPAS e entrevistados. No início da década de 1990, a política da fluoretação sistêmica através do sal de cozinha começou a ser formulada no Brasil, por influência do órgão internacional, que se posicionava a favor deste método. 
Matérias da mídia impressa abordavam a política de fluoretação do sal nas regiões Norte e Nordeste, nos locais onde não existiam estações de tratamento. Na publicação, Sergio Weyne defendia o método de fluoretação das águas como mais adequado à realidade brasileira. (MINISTÉRIO..., 1990)

Em 1990, foi editada uma Portaria, assinada pelo ministro Alceni Guerra, que criava o "Programa Nacional de Controle da Cárie Dentária”. A Portaria n 1.437, de 14 de dezembro de 1990, publicada no DOU, em 17 de dezembro de 1990, justificava a criação do Programa devido ao fato de que o "método coletivo de prevenção presentemente adotado de abastecimento de água fluoretada não oferece uma cobertura populacional com a abrangência requerida para reverter a prevalência dessa doença”. (BRASIL, 1990d, p. 2434)

Em 5 de fevereiro de 1991, através da Portaria $n^{\circ}$ 1, publicada no DOU, de 6 de fevereiro de 1991, assinada pelo presidente do INAN, Marcos de Carvalho Candau, ${ }^{63}$ e pelo diretor da DNSB, Sérgio de Carvalho Weyne, foi criada a Coordenadoria Geral do Programa Nacional de Controle da Cárie Dentária pelo método de fluoretação do sal.

As atribuições da referida coordenadoria eram:

- "responsabilizar-se pela implantação, execução, acompanhamento e avaliação do Programa Nacional de Controle da Cárie Dentária pelo método de fluoretação do sal";

- "por atos próprios, designar os componentes da estrutura organizacional do Programa e ainda outros atos”, de acordo com a primeira portaria publicada;

- "organizar, a cada ano, em datas regulamentares, a proposta orçamentária do Programa para o ano seguinte"; e

- “indicar ao Ministério da Saúde os componentes do Grupo Técnico Consultivo".

Alguns professores e pesquisadores da Universidade Estadual do Rio de Janeiro (UERJ), como o Hélio Wanderley Uchoa, da Rede Cedros, e da UFRJ, o Mário Chaves, eram favoráveis ao método da fluoretação do sal. A Rede Cedros foi criada em 1989 com o apoio financeiro da Fundação W. K. Kellog, sendo seu secretariado executivo localizado no Centro Colaborador para Pesquisas e Promoção de Saúde Bucal da OMS e da Faculdade de Odontologia da UFRJ. Tinha como meta "constituir-se em um elo unindo a profissão odontológica, representada por suas

Marcos de Carvalho Candau, sociólogo, então presidente do INAN. 
associações de classe, instituições de serviços e de educação, dedicadas ao ensino a pesquisa”. (CEDROS, 1998) Também buscava estreitar a relação entre o Brasil e outros países da América Latina, além de "estimular e facilitar projetos que envolvam universidades, serviços públicos e instituições privadas”. A coordenação era exercida por Roberto Vianna, Mário Chaves, Eymar Sampaio e Thomaz Chianca. Existiam sete grupos de trabalho, ressaltando-se três dentre estes:

- métodos de massa/fluoretação do sal, coordenado por Hélio Uchoa;

- Métodos de massa/fluoretação das águas, coordenado por Paulo Capel Narvai;

- Saúde Bucal nos SILOS, com coordenação de Sylvio Gevaerd. (CEDROS, 1998)

A Rede Cedros foi responsável pelo Projeto UNI, ${ }^{64}$ uma estratégia da Fundação Kellog de atuar no desenvolvimento de modelos de serviços locais de saúde, formação e capacitação de recursos humanos e de participação comunitária. (BOLETIM INFORMATIVO, 1993) Tanto o Mário Chaves, como o Hélio Uchoa haviam participado da FSESP que conduzira programas de fluoretação das águas em Baixo Guandú (ES) e Aimorés (MG), em 1953. Esse projeto teve resultados muito positivos que inspiraram os estados e os municípios a realizarem a fluoretação das águas de abastecimento público e aplicações tópicas em escolares como método de prevenção da cárie dentária. Entretanto, uma análise de quase 40 anos após a implantação do programa levou os pesquisadores a observar alguns problemas:

- limitação da implantação da fluoretação das águas de abastecimento pelos estados;

- constantes interrupções dos programas implantados decorrentes de problemas políticos;

64 Projeto UNI é a abreviação de "Uma nova iniciativa na formação dos profissionais de saúde: união com a comunidade". Os Projetos UNI foram desenvolvidos em países da América Latina, a partir da década de 1990, tendo sido financiados pelo Fundação W. K. Kellog. Buscavam atuar no desenvolvimento e nas relações entre universidade, sistema local de saúde e comunidade. Seus objetivos eram: (i) promover os movimentos de progresso sincrônico na educação, na prestação de serviços de saúde e na comunidade; (ii) criar e difundir modelos passiviveis de replicação referentes a estes três campos; (iii) apoiar modelos de Integração Docente Assistencial no âmbito do Sistema Local de Saúde, baseados no trabalho interdisciplinar e multiprofissional e na inovação de métodos pedagógicos; (iv) promover o aprimoramento da formação profissional dos graduandos na área de saúde, adequando-os à futura prática profissional e às necessidades de saúde da comunidade; (v) promover a participação comunitária nas decisões relativas ao setor de saúde; (vi) apoiar o desenvolvimento de lideranças na universidade, nos Serviços de Saúde e na Comunidade.(MACHADO; CALDAS JR; BORTONCELLO, 1997) 
- controle da dosagem do flúor, como a sub-dosagem; e

- paralisação de vários programas. (UCHOA, 2015)

Levando em consideração a análise realizada, o grupo de trabalho do método de massa para prevenção da cárie dentária através da fluoretação do sal de cozinha da Rede para Cooperação em Estudos e Desenvolvimento de Recursos Odontológicos para o Setor Saúde (Rede Cedros), passou a estudar a viabilidade de desenvolver um estudo visando definir a utilização do flúor no sal de cozinha, considerando como pressupostos:

- sua universalidade, pois o método de fluoretação do sal de cozinha iria cobrir significativa parcela da população dos centros urbanos e da zona rural, independentemente da sua condição socioeconômica, educacional ou idade, tendo em vista que todos consomem sal de cozinha, o que não ocorre, necessariamente, com a fluoretação dos sistemas de abastecimento d'água, limitado às pessoas que tem acesso à rede de distribuição e quase sempre, não atingindo os moradores da zona rural;

- o controle da dosagem do flúor no sal de cozinha, que seria realizado em apenas 12 refinarias que processavam o sal, cobrindo, aproximadamente, 80\% da população; no caso da fluoretação das águas, o controle da dosagem do flúor exigiria a organização de um sistema de vigilância bastante complexo em mais de 5 mil municípios;

- o custo, pois acreditava-se que dos métodos de prevenção da cárie dentária, a fluoretação do sal seria o menos dispendioso.Na época, segundo estimativa feita na França, o custo per capita com a operacionalização do método ficaria em US $\$ 0,02$, muito inferior ao demais métodos. Devendo-se destacar, ainda, que a fluoretação do sal seria de "custo zero" para os cofres públicos, tendo em vista que as empresas se adequariam às normas fornecendo os insumos; $\mathrm{e}$

- democratização pois o uso do sal de cozinha com flúor não seria compulsório, podendo a comercialização ser feita através do sal de cozinha com e sem flúor. (CHAVES, 1991; UCHOA, 2015)

Em seguida, o Mário Chaves se reuniu com o Marcos Candau, em 25 de janeiro de 1991, e com o presidente do INAN para discutir as bases de elaboração de um Convênio INAN - Ministério da Saúde com a Fundação Universitária José Bonifácio (FUJB)/UFRJ. 
O memorando enviado por Chaves ao presidente do INAN destaca a importância da cooperação entre a Rede Cedros e o Instituto para a implementação da fluoretação do sal nas três macrorregiões do Brasil assim como referia que o prof. Hélio Uchoa já dispunha de contatos em municípios e a necessidade de "um intercâmbio constante entre o projeto de apoio técnico-científico ao INAN no Rio de Janeiro e a Coordenação Geral e Executiva em Brasília, incluindo também o relacionamento com a Divisão Nacional de Saúde Bucal”. (CHAVES, 1991, p. 1) A pactuação da política foi uma confluência de interesses de agentes dos campos burocrático, científico e político.

Foi selecionado o município de Cabo Frio para a implantação do Projeto de Fluoretação do Sal de Cozinha, tendo em vista o interesse do prefeito, Ivo Saldanha, médico, que, como deputado estadual, já havia conseguido introduzir o Artigo 292 na Constituição do estado do Rio de Janeiro estabelecendo a produção do sal fluoretado. O Decreto Municipal n 1.721/1990 da prefeitura de Cabo Frio determinava à Secretaria de Saúde e Ação Social, fixar a dosagem de flúor a ser adicionada ao cloreto de sódio pela indústria produtora de sal no município. (SALDANHA et al., 1992)

As normas técnicas caracterizavam a cárie como um grave problema de saúde pública com alta prevalência e incidência, além de apontar que a fluoretação das águas não oferecia uma cobertura populacional com a "abrangência requerida para efetivamente reverter essa doença”, tendo em vista que sua expansão no país ocorreu de forma desigual sendo o maior progresso constatado nas regiões Sul e Sudeste, em detrimento das outras. Além disso, a fluoretação do sal poderia alcançar áreas não servidas por estações de tratamento de água. Neste sentido, o Ministério da Saúde definia a fluoretação do sal como um método complementar de prevenção da cárie em localidades não beneficiadas pela água fluoretada. (BRASIL, 1991c)

A execução do Programa ficou a cargo do INAN e da Fundação Nacional de Saúde que poderia manter convênios com órgãos nacionais e internacionais para este fim. Em 28 de fevereiro de 1991, foi editada a Portaria $\mathrm{n}^{\circ} 2$ do INAN que aprovava as Normas Técnicas para o desenvolvimento do Programa Nacional de Controle da Cárie Dentária, pelo método da fluoretação do sal. (BRASIL, 1991c)

A Portaria determinava um levantamento da situação da fluoretação das águas de abastecimento no Brasil, a fim de delimitar áreas de exclusão para o sal de cozinha. Fixou, também, que o produto a ser utilizado no sal seria o fluoreto de potássio em solução, com a dosagem de $250 \mathrm{mg}$ por quilo de sal, podendo variar entre 225 e $275 \mathrm{mg}$. (BRASIL, 1991c) 
Em termos operacionais, o Programa seria iniciado nas refinarias com infraestrutura adequada, estendendo-se, progressivamente, às outras. O INAN iria adquirir o fluoreto de potássio e a Fundação Nacional de Saúde o distribuiria às indústrias beneficiadoras de sal. As embalagens conteriam uma etiqueta verde com a expressão "sal fluorado" e a legenda "Este produto somente poderá ser consumido em localidades onde o teor de flúor na água de abastecimento for igual ou menor que meio miligrama por litro”. Por fim, as empresas seriam responsáveis por distribuir o produto nos locais que não se constituíssem zonas de exclusão definidas pelo Ministério da Saúde com base nos sistemas de abastecimento de água. Como mecanismos de acompanhamento, estabeleceu-se que a Fundação efetuaria a entrega do insumo, faria o monitoramento e prestaria assistência técnica. Cada indústria receberia o material de coleta de amostras que deveriam ser analisadas em laboratórios próprios. Os técnicos da Fundação Nacional de Saúde recolheriam, diariamente, as amostras, coletadas a cada 60 minutos pela empresa, para validação dos resultados obtidos pelos laboratórios das indústrias. O controle do sal fluoretado seria inicialmente implantado nos estados do Rio Grande do Norte, Rio de Janeiro, Ceará e Espírito Santo. (BRASIL, 1991c) Quanto à avaliação do Programa, coube à DNSB interpretar os resultados, realizar inquéritos epidemiológicos dos níveis de cárie e quanto à fluorose nas populações com sal fluorado. (BRASIL, 1991c)

Aproximadamente dois meses após o lançamento do Programa, aparecia na mídia certa divisão de opiniões entre profissionais e gestores. (USO..., 1991) As Secretarias Municipal e a Estadual de Saúde de São Paulo manifestaram repúdio à fluoretação do sal. O cirurgião-dentista Marco Manfredini, assessor de saúde bucal da Secretaria Municipal de Saúde de São Paulo, apontava a inexistência de um estudo piloto assim como o alto valor do produto. Já Pedro Martinelli, presidente da ABO elogiava o Programa.

A Aboprev noticiou o fato afirmando que o Programa deveria estar implementado até o dia 30 de junho, além dos integrantes do Grupo Técnico Consultivo para supervisão da política composto por Alfredo Reis Viegas, Rui Oppermann, Marisa Maltz e Jayme Aparecido Cury. (PROGRAMA..., 1991) Sérgio Weyne ratificava que a nova ação beneficiaria de 89 a 90\% da população mais desassistida, pela obrigatoriedade da venda do sal fluoretado nos locais sem água fluoretada. (PROGRAMA..., 1991) Outro anúncio foi a divulgação do lançamento do Programa e de outras ações pelo Ministério da Saúde, em parceria com a Aboprev e a empresa Colgate em programa de televisão da rede Bandeirantes. (NO DIA..., 1991) 
A empresa Colgate foi parceira da Aboprev em alguns eventos. A vertente defendida pela Associação ia ao encontro dos interesses daquela indústria.

Ainda em 13 de agosto de 1991, foi firmado convênio entre a prefeitura de Cabo Frio e a UERJ visando o desenvolvimento de estudos epidemiológicos para acompanhamento da fluoretação do sal. No ano seguinte, Sérgio de Carvalho Weyne foi exonerado do cargo de diretor do Departamento de Programas de Saúde, em 21 de janeiro de 1992, passando a ser nomeado como secretário nacional de Vigilância Sanitária do Ministério da Saúde. O dentista Mércio de Azevedo Ferreira assumiu, temporariamente, a gestão da DNSB. (BRASIL, 1992c)

Em Cabo Frio, deu-se seguimento às medidas de fluoretação do sal através do Decreto Municipal n 1.796/1992 que definia normas para a implantação do Programa Municipal, em convênio com a UERJ. Em abril de 1992, iniciou-se a realização de estudo epidemiológico ${ }^{65}$ visando determinar a prevalência dos problemas de saúde bucal (cárie dentária, periodontopatias, má-oclusão, fluorose) em crianças de 6 a 14 anos de idade, além de determinar a taxa de excreção de flúor pela urina em uma amostra da população do município de Cabo Frio e o teor de flúor nas fontes de abastecimento de água do município.

A empresa salineira Perynas conseguiu a aprovação do registro de dois produtos: o sal fluorado refinado e iodado, Biosal; e o sal fluorado refinado extra iodado, MOC, através da Portaria ${ }^{\circ} 110$, de 26 de agosto de 1992, publicada no DOU, em 28 de agosto de 1992. A direção da Companhia Salinas Perynas com o propósito de atender ao Decreto Municipal n 1796/1992 de Cabo Frio comunicou à Divisão de Produtos (Diprod), da Secretaria Nacional de Vigilância Sanitária do Ministério da Saúde que, a partir de 18 de junho de 1992, estaria fornecendo ao mercado consumidor de Cabo Frio, o sal fluorado, tendo recebido a aprovação do registro definitivo. (SALDANHA et al., 1992) Cabo Frio passou a utilizar o sal fluoretado produzido pela Companhia Salinas Perynas. O prefeito e os pesquisadores organizaram uma publicação sobre o histórico da fluoretação do sal em Cabo Frio, desde o Gecahy, um sal colhido nas margens da lagoa Araruama e pilado com pimenta, utilizado

65 Participaram do estudo epidemiológico: Helio Wanderley Uchôa, prof. titular de Odontologia Social da FOUERJ, como coordenador; Eymar Sampaio Lopes, prof. titular de Odontologia Social da FOBauru (SP); Luiz Octávio Coelho Guimarães, prof. titular de Odontologia Social da Faculdade de Higiene e Saúde Pública da USP; Maria Lucilda Tavares de Mello, profa ${ }^{\text {. ad- }}$ junta de Odontologia Social da FOUERJ; Francisco de Assis Ramos de Souza, coordenador de Odontologia da Secretaria Municipal de Saúde e Ação Social da Prefeitura Municipal de Cabo Frio; João Baptista Gonçalves, prof. adjunto de Odontologia Social da FO da Universidade Federal de Goiás (UFGO); Wilkens Oliveira de Souza, assistente de Coordenação de Saúde Oral da Fundação Nacional de Saúde (MS); e Thomaz Chianca, secretário executivo da Rede Cedros. 
como tempero, até o sal fluoretado. Também foi abordado o convênio com a FOUERJ e as ações desenvolvidas pela gestão para este fim.

No nível municipal, a implantação oficial do Programa Fluoretação do Sal em Cabo Frio (RJ) foi celebrada com a presença dos presidentes dos Conselhos Regionais de Odontologia (CRO) de São Paulo e do Rio de Janeiro, ABO Nacional, ABO/ RJ, APCD, docentes da UERJ, UFRJ e USP, membros da Rede Cedros, prefeito de Cabo Frio e de vários municípios do estado, diretores e funcionários da Cia. Salinas Perynas. (ABORJ, 1993; CHAVES, 1992; UCHOA, 2015)

Jornais das associações de classe como a ABO nacional e do Rio de Janeiro, assim como a Rede Cedros, através de um editorial escrito por Mário de Magalhães Chaves, expressaram apreciação ao movimento de fluoretação do sal nos municípios, atribuindo grande esperança de redução dos índices de cárie na população brasileira. Chaves (1992) citou a conformação de dois grupos do campo odontológico que se opunham um ao outro, o dos defensores da fluoretação das águas e o dos defensores da fluoretação do sal. Atribuindo o sucesso ao bom senso, explicou a mudança de estratégia que deslocou o eixo de decisão do nível central para o periférico.

Iniciada com uma citação de Pitágoras que afirma que o sal é nascido dos mais puros pais: o sol e o mar, ${ }^{66}$ publicação da Organização Panamericana da Saúde (OPAS) traz histórico de sucesso da fluoretação do sal, além de preconizar como planejar e implementar um programa de fluoretação do sal. (PAHO, 2005)

Os autores apontam que este método vem sendo conduzido há mais de meio século na Europa e nas Américas, tendo sido desenvolvido à semelhança da adição de iodo no sal de cozinha para prevenção de doenças ocasionadas pela supressão desse nutriente. (PAHO, 2005) Os métodos de fluoretação do sal e de fluoretação das águas são modos de aplicação sistêmicos do flúor cuja associação é contraindicada (EIDELWEIN, 2010) ao passo que é possível combinar métodos de uso tópico e sistêmico, como a utilização de dentifrícios fluoretados com a água ou o sal. O uso dos dentifrícios também é recomendado para países com baixa prevalência de cárie, já os métodos sistêmicos são indicados para aqueles países com elevada ou moderada prevalência da doença. (EIDELWEIN, 2010) Criticando a fluoretação do sal, Neder ${ }^{67}$ e Manfredini ${ }^{68}$ (1991) apontaram uma obsessão do governo Collor por

66 Tradução livre feita pela autora. Fragmento original: "Salt is born of the purest of parents: the sun and the sea" Pythagoras. (PAHO, 2005).

67 Carlos Neder, médico formado pela USP, mestre em Saúde Pública pela Unicamp, vereador na Câmara Municipal de São Paulo, por quatro mandatos, e deputado estadual do estado.

68 Marco Antonio Manfredini é dentista, mestre em Ciências, doutor pela FSP/USP. Integrou o MBRO, foi coordenador Municipal de Saúde Bucal em São Paulo (1989-1991) e Santos 
“modernidade" e pela inclusão do Brasil no primeiro mundo, o que poderia ter um custo alto ao país.

Comentaram a ausência de discussões técnico-científicas e a perplexidade dos gestores e profissionais do setor nos estados ao tomarem conhecimento da Portaria que instituía o Programa de fluoretação através do sal de cozinha, tendo em vista a existência da Lei n 6050/1974 que instituía a fluoretação das águas, com a mesma finalidade de combate à cárie com método sistêmico.

Os autores apontaram que a fluoretação das águas beneficiava cerca de 66 milhões de pessoas à época, com um custo baixo, justificando que o país era autossuficiente na produção dos insumos necessários e a fluoretação do sal de cozinha exigiria importação do fluoreto de potássio de um único produtor alemão. Ademais, o trabalho cita as políticas empreendidas e todo o investimento realizado (NEDER; MANFREDINI, 1991), já referidos anteriormente, pelo método sistêmico utilizando a água que também envolveram o INAN, a FSESP, o Ministério da Saúde e o IPEA.

Esse ponto de vista mostrava também que, naquelas comunidades onde havia água fluoretada, existia redução nos indicadores de cárie e a necessidade de controle efetivo não ocasionava um defeito quanto ao método em si. Ademais, citaram que a fluoretação das águas estava implantada em cerca de 50 países, como os Estados Unidos e a União Soviética. Por fim, argumentaram que o país não definia uma política nacional de saúde bucal democrática para ser seguida em todo o território, apontando para políticas anteriores efêmeras, como o Precad e o Programa Nacional de Controle da Cárie Dentária com uso de Selantes e Flúor (PNCCSF) assim como a necessidade de discussão ampliada sobre o tema. (NEDER; MANFREDINI, 1991)

Os agentes do campo burocrático buscaram sustentação para a política no campo legislativo. Existem cinco ocorrências de atos legislativos no período de 1990 a 1993 na Câmara dos Deputados do Brasil, sendo dois projetos de lei (PL), dois requerimentos de informação e uma identificação da proposição.

Em 1991, dois requerimentos de informação foram submetidos pelo então deputado federal Eduardo Jorge ${ }^{69}$ do Partidos dos Trabalhadores (PT) de São Paulo ao ministro Alceni Guerra sobre a fluoretação do sal de cozinha e solicitando esclarecimentos sobre o respectivo programa. Ambos foram arquivados. O Projeto

(1993-1996), membro da Comissão Técnica de Assessoramento à Coordenação Nacional de Saúde Bucal do Ministério da Saúde (2004-2015).

69 Eduardo Jorge Martins Alves Sobrinho nasceu em 26 de outubro de 1949, em Salvador (BA), é médico. Era filiado ao PT, hoje faz parte do Partido Verde (PV). 
de Lei $\mathrm{n}^{\circ} 1.133 / 1991$, de autoria da deputada Regina Gordilho ${ }^{70}$ do Partido Democrático Trabalhista (PDT), do Rio de Janeiro foi apresentado em 18 de junho de 1991 e tinha como objetivo tornar obrigatória a fluoretação do cloreto de sódio pelas indústrias produtoras em todo o território nacional. (BRASIL, 1991b) Apesar de ter obtido parecer favorável pelo relator, o deputado Maurílio Ferreira Lima, ${ }^{71} \mathrm{o}$ projeto de lei não foi apreciado na Comissão de Justiça, tendo sido arquivado. Em 1 de junho de 1992, foi submetido o PL n².852/1992, pelo deputado José Maria Eymael, ${ }^{72}$ do Partido Democrata Cristão (PDC) de São Paulo, que buscava estabelecer a obrigatoriedade de fluoretação da água distribuída para consumo humano. (BRASIL, 1992a) O Projeto recebeu parecer contrário do deputado Antonio Faleiros, ${ }^{73}$ do Partido do Movimento Democrático Brasileiro (PMDB) de Minas Gerais, devido à existência de Lei anterior, a de $n^{\circ}$ 6.050, de 24 de maio de 1974, e outras portarias do Ministério da Saúde que regulamentam e aprovam normas e padrões sobre a fluoretação da água dos sistemas públicos e, assim, o objeto já estaria sendo atingido por instrumentos legais vigentes.

No ano de 1993, uma Identificação de Proposição (INC) 344/1993 é feita pelo deputado Pedro Correa ${ }^{74}$ do Partido da Frente Liberal (PFL) de Pernambuco sugerindo ao poder executivo, através do Ministro da Saúde, que se processe a fluoretação do sal refinado ou moído e que as indústrias beneficiadas do sal deverão adquirir o equipamento e o fluoreto de sódio necessários. Os deputados e senadores dos partidos PDT e PFL se posicionaram como favoráveis à fluoretação do sal. O PFL integrava a base aliada do PRN. Já aqueles do PT, PDC e PMDB, partidos de oposição ao governo, adotaram ponto de vista contrário.

Tratando sobre as experiências exitosas em outros países, a publicação da OPAS citou que a viabilidade do programa na Jamaica foi atribuída à existência de um único produtor, sendo que o programa implantado atingiu grande sucesso na redução da cárie dentária. (PAHO, 2005) Este fato é distinto do que ocorria no Brasil, tendo em vista que existiam muitos produtores de sal de diferentes portes, o

70 Regina Helena Costa Gordilho, empresária, nasceu em 12 de maio de 1933 em Salvador.

71 Maurílio Figueira de Ferreira Lima nasceu em 29 de março de 1940, em Limoeiro (PE). É advogado, filiado ao PMDB.

72 José Maria Eymael nasceu, em 1939, na cidade de Porto Alegre (RS). É graduado em Filosofia e Direito, era filiado ao PDC e, em 1995, fundou o Partido Social Democrata Cristão (PSDC).

73 Antonio Faleiros Filho nasceu em 12 de janeiro de 1948, em Estrela do Sul. É médico, especializado em obstetrícia e medicina do trabalho. Era deputado federal pelo PMDB de Goiás.

74 Pedro da Silva Correa de Oliveira Andrade Neto, médico, nasceu em 7 de janeiro de 1948, no Rio de Janeiro (RJ). No momento da indicação, era filiado ao PFL. Antes do PFL foi da Arena e atualmente é filiado ao Partido Popular (PP). 
que ocasionava diferentes tipos de produtos, sendo que o método da fluoretação do sal exigia um controle rígido para o sucesso da técnica. Ademais, os consultores do Ministério da Saúde à época temiam um aumento do custo do sal de cozinha para a população, tendo em vista que não existia produção nacional do insumo para o modo de uso citado, causando a necessidade de importação da Alemanha e isto faria com que um produto que era de amplo acesso e uso da população, pudesse deixar de sê-lo devido aos altos custos do material.

Foi uma comissão visitar as salineiras no Rio Grande do Norte. Uma coisa é fluoretar o sal do Uruguai que não produz sal, importar todo seu sal, e portanto tem o controle na fonte. Outra coisa é chegar no Rio Grande do Norte e dar conta que tinha trezentos produtores de sal, com as mais variadas e diferentes formas tecnológicas, uns mais sofisticados e outros menos. A gente percebeu que poderia haver um risco de monopolização na produção do sal, matando os 'pequeninhos' que não teriam a menor condição de fluoretar. A fluoretação do sal requer uma produção de baixa concentração de umidade e aquelas salineiras não tinha a menor chance, o sal vem úmido, e o sal úmido o que acontece? o flúor fica na fase líquida que acaba se concentrando e não se distribuindo uniformemente no sal. Então, tem que ter um processo de produção que faça com que essa concentração fique distribuída adequadamente no sal. A gente criou informes técnicos de incapacidade de produção e de segurança da fluoretação do sal no Brasil. Isso por um lado, pelo outro lado a ideia de que o sal refinado eventualmente fluoretado no Brasil seria tão caro que seria inacessível a quem também era inacessível a água. (Entrevistado 9, dentista, consultor, professor universitário)

As salineiras que pleiteavam o comércio do produto foram alvo de inspeção e testes por comissão da DNSB do Ministério da Saúde. A comissão concluiu que as empresas não dispunham do controle necessário para a distribuição homogênea do flúor no sal e o alcance das especificações mínimas de qualidade. De forma contrária à adição de iodo no sal de cozinha, as diferentes concentrações de flúor encontradas nas amostras testadas poderiam ocasionar sérios riscos de fluorose à população brasileira.

Segundo o Entrevistado 9, o assédio que os consultores sofreram em visitas às salineiras para testar os produtos revela os interesses econômicos em jogo. Alguns empresários de grandes salineiras fizeram propostas consideradas pelos entrevistados como indecorosas aos técnicos do Ministério da Saúde tentando pactuar padrões de qualidade inalcançáveis aos pequenos produtores e assim assegurar seu monopólio, o que implicava uma forma de corrupção. A moeda de barganha era 
que as empresas custeariam a produção do sal e o Ministério da Saúde não necessitaria subsidiar o produto.

$\mathrm{Na}$ visita técnica para avaliação, realizada por consultores do Ministério da Saúde em Cabo Frio, ficou evidente que a empresa possuía privilégio de informações e já dispunha do produto pronto para venda. O intuito era ser a empresa pioneira na venda do sal fluoretado no Brasil. Outro entrevistado suspeitou de esquema de corrupção que perpassava o processo de fluoretação do sal de cozinha.

No nível nacional, a FIO, através de seu presidente Swendenberg Barbosa, solicitou ao Ministro da Saúde, em audiência concedida em 28 de abril de 1992, a adoção de uma política baseada nas resoluções da I CNSB e nos Enatespo, assim como a obrigatoriedade das ações de Odontologia no SUS, com dotação orçamentária específica. Solicitou, também, apoio para a realização da II CNSB e a ampliação da infraestrutura e recursos humanos para a DNSB, apesar de terem se abstido da indicação de um nome para ocupar a coordenação. (FIO..., 1992b)

O documento final do VIII Enatespo, realizado em São Paulo (SP), de 21 a 25 de outubro, destacava que os programas de fluoretação do sal de cozinha não deveriam ser implementados, mesmo que, em algumas reuniões, sem ampla discussão com a sociedade civil e as instâncias políticas como o Congresso Nacional, reafirmando a luta pelo provimento das águas de abastecimento público de "boa qualidade, clorada e fluoretada para todos os brasileiros”. (ENATESPO, 1991) Outro ponto de destaque foi a inadequação da prática odontológica ainda vigente no país, centrada em ações clínico-cirúrgicas individuais e em enfoques biologicistas "em detrimento da compreensão e enfrentamento dos determinantes sociais do processo saúde-doença”. (ENATESPO, 1991) A tomada de posição do Enatespo era consonante com o Movimento da Reforma Sanitária Brasileira.

O documento, publicizado através de número especial da revista Saúde em Debate relacionado ao VIII Enatespo, apresenta textos nos quais se pode apreender as tomadas de posição do grupo. Foi recomendado que o projeto municipal de saúde contivesse estudo aproximado da realidade, contemplando os determinantes sociais, a identificação de problemas de saúde bucal a partir da epidemiologia, modelo assistencial baseado na integralidade das ações de SB com ênfase nas ações básicas, método preventivo-educativo, utilização de pessoal auxiliar, sistemas de trabalho de cobertura ampla, a criação de centros de referência para atenção de níveis secundário e terciário, sistemas de referência e contra referência, instrumentos adequados para avaliar o impacto das ações desenvolvidas e definição clara dos recursos financeiros. Destacou-se, também, os recursos humanos e o controle social. (SOUZA, 1991) 
Ademais, a plenária apontou a ausência de um documento oficial que traduzisse a PNSB do governo Collor e ainda que tenha reconhecido que a coordenação de saúde bucal do Ministério da Saúde tivesse incorporado algumas propostas oriundas dos Enatespo e de outras instâncias democráticas, isto não era suficiente para assegurar a implantação e a continuidade das ações pois apenas o processo democrático de elaboração poderia legitimar e assegurar a continuidade da proposta da política nos níveis nacional, estadual e municipal. (ENATESPO, 1991) O documento também reivindicava a convocação da II CNSB e reiterava a defesa pela democracia e seu desenvolvimento no país.

Os consultores do Ministério da Saúde concluíram pela inviabilidade da fluoretação do sal, no Brasil, em condições seguras e recomendaram a descontinuidade do Programa. Ademais, era inconstitucional a existência de duas leis sobre fluoretação em território nacional. Assim, foi demandado parecer da Procuradoria Jurídica, tendo sido atestado o exposto. O ministro Alceni Guerra foi exonerado e em seu lugar foi nomeado o ministro Adib Jatene que, ao receber o citado parecer da Procuradoria Jurídica, decidiu pela extinção do Programa.

Não era possível fazer responsavelmente. Se pudesse fazer para a região Norte com certeza teria sido feito, porque a região norte nunca teve sistema de água fluoretada [...] houve esse interesse para estudar a possibilidade do sal com flúor, mas de novo era método coletivo e o estudo era para ver a possibilidade de em áreas que não tem, especialmente a região Norte e alguma parte do Nordeste era introduzir sal com flúor mas operacionalmente não era possível. Eram 400 empresas salineiras como é que ia controlar? Qual a dose que você ia usar? Se vocêfosse usar no Rio Grande do Sul, os gaúchos comem muito sal, você tinha que baixar a quantidade de flúor, se fosse usar no Norte, o uso é menor, você tinh a que aumentar a concentração de flúor, então tinha uma dosagem mas isso era verdadeiro em uma determinada localidade. (Entrevistado 14, dentista, professor universitário)

Assim, a Portaria ${ }^{\circ}$ 851, de 4 de agosto de 1992, publicada em 7 de agosto, cita o parecer da Consultoria Jurídica no sentido da edição da Lei Federal existente para imposição da obrigatoriedade da fluoretação do sal destinado ao consumo humano resolveu cancelar a Portaria que regulamentava o Programa Nacional de Controle da Cárie pelo método de fluoretação do sal. (BRASIL, 1992e) Após, os registros dos produtos alimentícios Biosal e MOC da empresa Cia. Salinas Perynas foi cancelado, através da Portaria n 43, de 4 de maio de 1993.

Apesar do cancelamento do Programa, o prefeito de Cabo Frio, Ivo Saldanha, divulgou a manutenção do Decreto Municipal assim como a continuidade da pro- 
dução e comercialização do sal fluoretado. A Associação dos Salineiros impetrou um Mandato de Segurança a fim de invalidar o Decreto Municipal. O prefeito justificou a ação devido ao país ser um campeão mundial em cáries. (GUEDES, 1992)

A ABO, através do seu presidente Pedro Martinelli, enviou carta ao Ministro criticando a extinção do Programa, a ausência de um diretor na Coordenação Nacional de Saúde Bucal e o distanciamento do setor das entidades de classe odontológicas. (ABO, 1992) Ademais, afirmou existir um temor de "[...] não estarmos tomando as decisões mais corretas na defesa da saúde de nossa comunidade”. (ABO, 1992, p. 13)

Houve uma mobilização político-partidária crítica à decisão de Adib Jatene e buscando retroagir a decisão por meio de manifestos e de novas iniciativas legislativas. O deputado federal Flávio Palmier da Veiga, do Partido da Reconstrução Nacional (PRN) do Rio de Janeiro, ${ }^{75}$ através de um abaixo assinado, "em nome da classe odontológica e em benefício do povo brasileiro", solicitava o cancelamento da Portaria MS/GM no 43/1993 que retirou o registro dos produtos Biosal e MOC. (VEIGA, 1993) O deputado também criticou o coordenador nacional de Saúde Bucal, em exercício, dr. Mércio de Azevedo Ferreira, por ter afirmado em entrevista ao jornal $O$ Globo que metade da população brasileira era beneficiária de água fluoretada em sua residência. (VEIGA, 1993)

No âmbito do Congresso Nacional, dois projetos de lei e um requerimento de informações com o tema da fluoretação, no período citado, foram elaborados por senadores. Os três atos legislativos foram da autoria do senador Júlio Campos, ${ }^{76}$ do Partido da Frente Liberal (PFL).

Em 30 de junho de 1993, foi aberto o requerimento no 656/1993 solicitando informações ao Ministro da Saúde relacionadas à suspensão da fluoretação do sal no Brasil. No ano seguinte, em 23 de março de 1994, o mesmo senador elabora o Projeto de Lei $n^{\circ} 19 / 1994$ que dispunha sobre a obrigatoriedade da fluoretação do sal que, entretanto, foi arquivado no ano seguinte. Em 1997, há nova tentativa, através do PL n $58 / 1997$ com objeto semelhante que também é arquivado em 1999.

A decisão do ministro Adib Jatene pela suspensão do projeto foi apoiada por vários sanitaristas que participaram de projetos e movimentos a favor da fluore-

75 Flávio Palmier da Veiga nasceu em 2 de fevereiro de 1932. Era advogado e professor universitário, foi vereador, deputado estadual do Rio de Janeiro, por seis mandatos, e deputado federal, por três mandatos.

76 Júlio José de Campos nasceu em 11 de dezembro de 1946, em Várzea Grande. É engenheiro e empresário. No período, foi senador pelo estado de Mato Grosso pelo Partido da Frente Liberal (PFL). 
tação das águas de abastecimento público desde a década de 1950, além dos integrantes que haviam participado do MBRO e dos Enatespo assim como pela Aboprev.

A Rede Cedros seguiu publicando em seus jornais experiências exitosas de fluoretação do sal na Costa Rica, México, França, mas, também, estudos sobre o flúor na água. Entretanto, além da polarização em torno dos grupos que eram contra ou a favor da fluoretação do sal, existiam cirurgiões dentistas do movimento anti-flúor sistêmico que também eram contrários à fluoretação da água.

Manifesto na internet intitulado “Flúor na água não” aponta que o site Fluoride Action Network iniciou um movimento pedindo o fim da fluoretação das águas e já contava com mais de 1000 pessoas até 2007, sendo seis destes profissionais: Nelson Luiz Busatta, de Tapurah, dentista; Alexandre Cruz, do Rio de Janeiro, hidrogeólogo; Luciano Fonseca, de Juiz de Fora, médico; Jorge Jamili, do Rio de Janeiro, médico; Olympio Faissol Pinto, do Rio de Janeiro, dentista; e Paula Yamaguti, de São Paulo, dentista.

As causas explicitadas para o pleito afirmam que o fluoreto não é um nutriente essencial, que nenhuma doença jamais foi ligada à deficiência de fluoreto, que o benefício do flúor é principalmente tópico e não sistêmico e que o flúor seria um veneno cumulativo e, portanto, já que o flúor é desnecessário, não haveria razão para forçar as pessoas a beber o flúor em seu suprimento na água. (CRUZ, 2007)

Olympio Faissol Pinto, ${ }^{77}$ dentista de muitos políticos, como Fernando Collor e Brizola, além de outros artistas, deu uma entrevista no Programa Jô Soares, da Rede Globo, argumentando os motivos contra o flúor sistêmico e criticando a fluoretação das águas no Brasil, em maio de 1990. Aproximadamente dez dias depois, o Ministério da Saúde enviou o consultor Jaime Cury ${ }^{78}$ que explicou os motivos e a ação do flúor defendidos pela Coordenação Nacional de Saúde Bucal.

Motivo de destaque não apenas na mídia televisiva, o tema controverso do flúor também ganhou página inteira de discussão sobre toxicidade, possíveis malefícios assim como o posicionamento da Aboprev a favor da fluoretação. A matéria ilustra as distintas tomadas de posição coexistentes no espaço. De um lado, os críticos do flúor sistêmico na água e, do outro, seus defensores representados na

77 Olympio Faissol Pinto formou-se em Odontologia pela UFRJ, em 1957, e possui mestrado em Odontologia pela Georgetown University (1960). É membro Fundador da Sociedade Brasileira de Reabilitação Oral, cirurgião dentista da Clínica Odontológica Olympio Faissol Pinto.

78 Entrevista concedida por Jaime Cury no Programa Jô Soares na rede Globo em maio de 1990. 
matéria por Yvonne Buischi, presidente da Aboprev no período. (FOLHA DE SÃO PAULO, 1990)

Os dentistas associados à Aboprev realizaram eventos científicos contrapondo diferentes opiniões sobre o flúor. Foram realizados dois eventos denominados SIM Flúor, um em Porto Alegre e outro no Rio de Janeiro, trazendo os argumentos científicos nos quais se baseava a defesa do flúor na água.

Era assim absolutamente anti-flúor, ele chamou todos aqueles fundamentalistas contrários ao flúor, os que tem nos Estados Unidos e na época e nós fizemos os Sim flúor. Era o simpósio com relação ao flúor, e nesse simpósio chamamos, confrontamos pessoas a favor e contra o flúor, não era para fazer um simpósio a favor do flúor, era para as pessoas verem o anti-flúor e o a favor do flúor. Tinha um que trouxe um filminho de uma vaca se quebrando toda porfluorose bovina e ele mostrava isso com uma planta de alumínio no fundo soltando fumaça dizendo: - 'Olha essa vaca está se esfacelando porque os ossos tem muito flúor' e aí ele terminava assim: 'É isso que vocês querem pros filhos de vocês?' [...] então saiu na imprensa que todo mundo ia morrer com afluorose, que afluorose deixava os ossos fracos e a mesmo tempo a gente tinha uma contraposição acadêmica. Veio gente dos Estados Unidos, veio gente da Noruega, da Inglaterra, verdadeiros acadêmicos, não aqueles fundamentalistase ganhou a questão acadêmica definitivamente [...]. (Entrevistado 9, dentista, consultor, professor universitário)

Faissol também presidiu evento científico, o congresso Eco Odonto Rio 92, com muitos pesquisadores de outros países, enfocando diversos temas e, dentre eles, a toxicidade do amálgama e os problemas relacionados ao flúor sistêmico. Em entrevista ao Jornal do Rio, da Rede Bandeirantes, Faissol ${ }^{79}$ enfatizou:

O Brasil tem 66 escolas de Odontologia e 11 mil dentistas, eu acho que chegamos num ponto em que o povo vai deixar de acreditar na Odontologia se nós não fizermos alguma coisa. Nós temos aí mais de 40 anos de campanha de prevenção colocando flúor na água e não melhorou nada, que negócio é esse? Então um erro de 40 anos deverá prosseguir?

O dentista também explicou, em entrevista ao Programa Bom Dia Rio, da Rede Globo fluminense, em 1992, que sua defesa anti-flúor se iniciou na década

79 Entrevista concedida por Olympio Faissol Pinto a Frederico Roriz do Jornal do Rio da rede Bandeirande de Televisão na ocasião do evento Eco Odonto Rio 92. Rio de Janeiro, Rede Bandeirantes, 1992. 
de 1960, em um estudo seu, nos Estados Unidos, que teve ampla aceitação pelos profissionais renomados americanos.

Em outros programas de televisão, Faissol levou pesquisadores americanos que reforçavam seus argumentos. O tema também ganhou destaque em jornais de veiculação em todo Brasil, como o Jornal Nacional, da Rede Globo, que veiculou a ocorrência do Congresso Eco Odonto 92 com a tese anti-flúor, mas, também, as respostas do Ministério da Saúde e da Aboprev.

O presidente Fernando Collor de Mello sofreu impeachment em 29 de dezembro de 1992 e Itamar Franco assumiu a presidência da República. Nos anos subsequentes, as discussões polêmicas sobre a fluoretação do sal de cozinha e das águas de abastecimento público permaneceram em pauta.

O Jornal da Aboprev descreveu um simpósio realizado em 1993 com a participação do Hélio Uchoa, da FOUERJ e Rede Cedros, Roberto Vianna, da Rede Cedros, e Jaime Cury, da Aboprev (ABO..., 1993) para contrapor os pontos de vista sobre o flúor em defesa da fluoretação das águas. A Rede Cedros publicou dados da fluoretação do sal em seus boletins, quanto à experiência no México (BOLETIM INFORMATIVO, 1993), Costa Rica (BOLETIM INFORMATIVO, 1994) e França. (BOLETIM INFORMATIVO, 1995)

Após passar por nova reestruturação interna, o Ministério da Saúde passou a denominar a antiga DNSB como Coordenação de Saúde Bucal. José Carlos Cativo Gedeão, do campo burocrático, é nomeado coordenador de Saúde Bucal, em 24 de maio de 1993. Em 14 de julho de 1993, o ministro da Saúde Jamil Haddad designa comissão para planejar a II CNSB. Os membros efetivos da comissão foram: Swendenberg Barbosa, pelo Conselho Nacional de Saúde, coordenador geral da II CNSB; José Carlos Cativo Gedeão, pelo Ministério da Saúde; Hosana Garcez Moreira e Edila Sinedino Maioranna, pelas entidades associativas odontológicas; Olga Barbosa Laranjeiras, pelo Conselho Nacional de Secretários de Saúde (Conass); Déa Costa Ramos, pelo Conselho Nacional de Secretarias Municipais de Saúde (Conasems); Osdyr Brasileiro Matos, pelo governo do Distrito Federal; Maria do Amparo Vieira de Souza e Elson Nildes Soares, como representante dos usuários.

A II CNSB ocorreu de 25 a 27 de setembro de 1993 e aprovou diretrizes e estratégias políticas para a saúde bucal no país, considerando-a como um direito, um novo modelo de atenção à saúde bucal, recursos humanos, financiamento e controle social.

No período de 1993 a 1995, foram desenvolvidas poucas ações na coordenação de saúde bucal. João Antônio Caminha, professor da UFRGS, prestou consultoria neste período. O coordenador não fez nenhuma intervenção significante, com 
exceção do desenvolvimento de uma ficha de registro odontológico que permitia o registro de procedimentos individuais e ações coletivas como palestras, ensino de escovação, dentre outras.

Quanto ao planejamento orçamentário das ações de saúde bucal no período de 1990 a 1994, que expressam o grau de priorização das ações ao interior do governo, observa-se maior montante gasto em 1990, quando ainda existiam ações de assistência previdenciárias de saúde bucal (Tabela 3). Nos anos subsequentes, o percentual destinado às ações de saúde bucal foi bastante reduzido, principalmente após a saída de Sergio Weyne do cargo de diretor da DNSB. O orçamento de 1994 representou 0,04\% do planejado para o Ministério da Saúde, sendo menor que aquele de 1989, quando a DNSB estava no início da implementação de suas ações quando representava 0,10\%. Destaca-se, também, que a proporção dos valores destinados à saúde bucal neste período superou bastante aquele investido na segunda metade da década de 1980 (Tabela 3).

Em 1995, assumiu a dentista e especialista em saúde pública, Sônia Maria Dantas de Souza, de Belém (PA), que foi responsável pela implementação da política de inserção da Saúde Bucal no PSF, no ano 2000, objeto do próximo capítulo deste trabalho.

No período compreendido entre 1990 e 1994, em síntese, a PNSB priorizou o controle da cárie. O espaço da PNSB ficou polarizado pelo debate entre sanitaristas ou profissionais vinculados ao campo burocrático, que defendiam a fluoretação da água, e o polo do mercado, que propugnava a introdução da fluoretação do sal (Quadro 10). 


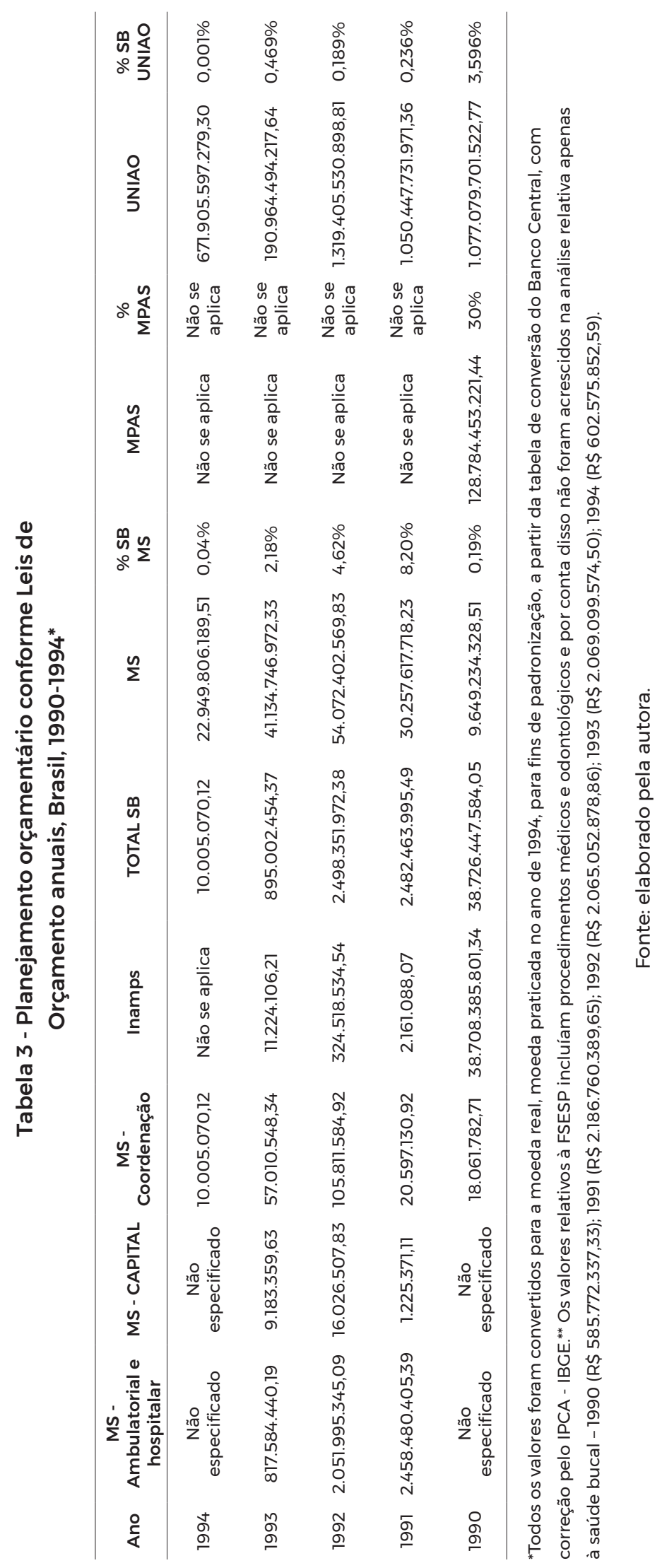

Produção Social da Políticas de Saúde Bucal no Brasil / 141 


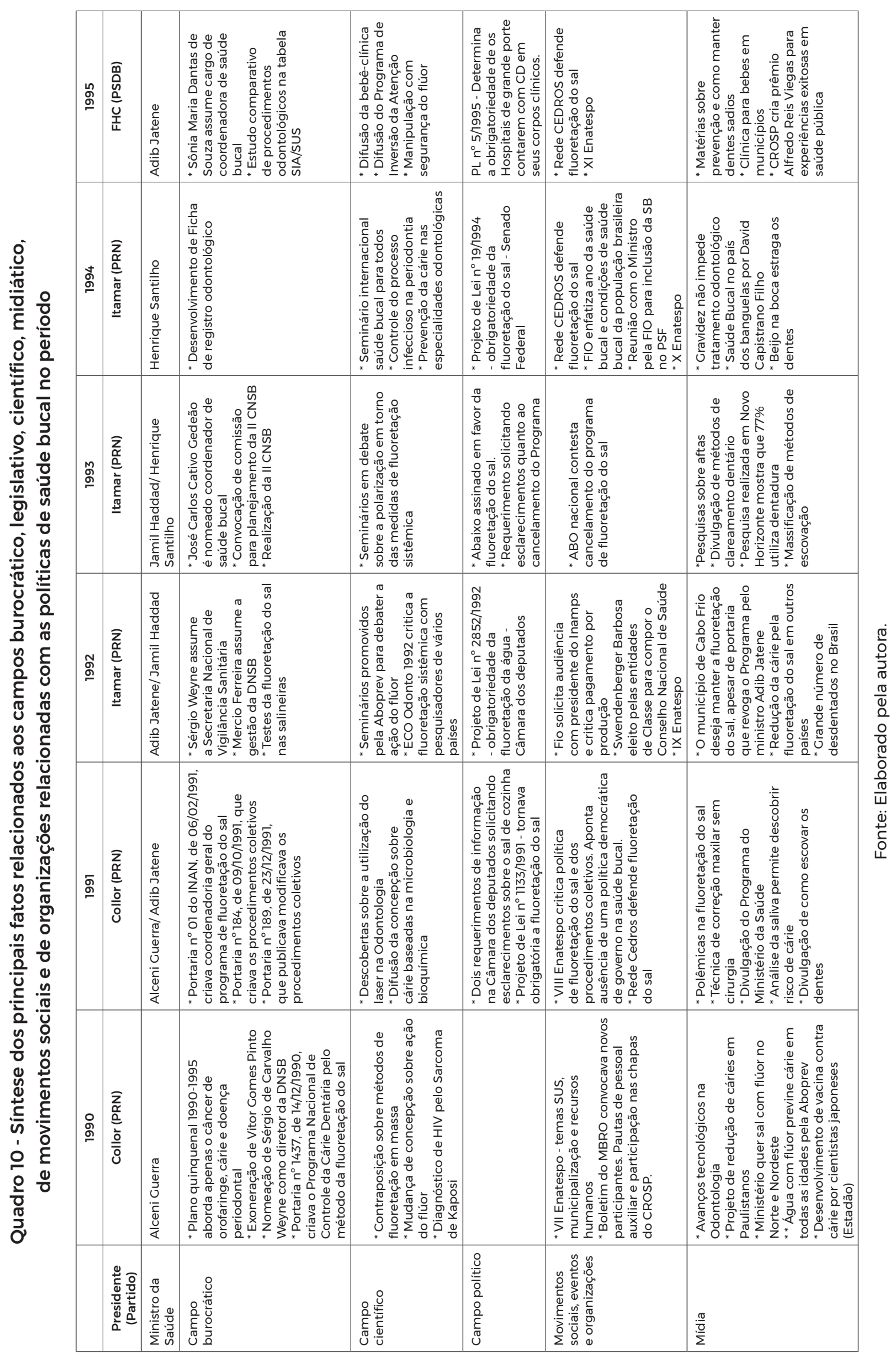

142 / Thais Regis Aranha Rossi 


\section{Grupos e agentes que influenciaram o espaço de formulação da política}

Após um resgate historiográfico das principais respostas do Estado quanto aos problemas bucais da população brasileira, no período de 1990 a 1993, duas políticas foram destacadas, a mudança de procedimentos na tabela SIA-SUS com os procedimentos coletivos e a tentativa de fluoretação do sal de cozinha.

Nas duas políticas, observa-se a forte influência que a Aboprev exerceu, seja através de congressos e publicações no campo científico seja através da presença de seus membros na gestão ou em comissões de assessoramento à DNSB do Ministério da Saúde.

O Quadro 11 mostra uma faixa etária de 54 a 90 anos dentre os entrevistados que influenciaram o espaço de formulação das políticas no período citado. A quase totalidade pertencia ao sexo masculino e todos eram graduados em Odontologia. Observou-se diferenças geracionais relacionadas às tomadas de posição. Os agentes mais velhos defendiam a fluoretação do sal, como Mário Chaves e Hélio Wanderley Uchoa, ambos da Rede Cedros. Dentre aqueles de geração intermediária, estavam Pedro Martinelli, presidente da ABO, nascido em 1943, que apoiava a fluoretação do sal, os membros da Aboprev e consultores do MS. Os mais jovens integravam o MBRO que, a partir do início da década de 1990, deixa de ser tão atuante como na década de 1980 e as críticas passam a ser exercidas nos Enatespo (Quadro 11).

Dentre as ocupações dos entrevistados no momento da entrevista, muitos pertenciam ao campo científico ou se encontravam, simultaneamente, nos campos científico e burocrático. Outros entrevistados faziam parte apenas do campo burocrático, exercendo ou participando da gestão, no nível estadual ou municipal. Devido ao tempo decorrido superior a 20 anos do período de estudo ao momento da entrevista, muitos já se encontravam aposentados. Entretanto, aqueles com faixa etária menor ainda se encontravam em plena atividade de docência, em cargos burocráticos ou políticos. Alguns ainda permaneciam acompanhando e integrando movimentos de crítica às políticas nacionais de saúde bucal no país.

A inserção dos dentistas que ocupavam o espaço de formulação e crítica das políticas era predominantemente burocrática. Dentre os consultores, existiam aqueles que se inseriam no campo científico com grande acumulação de capital científico. O cargo máximo na Coordenação de Saúde Bucal, inicialmente chamada de DNSB, era ocupado por agente com inserção predominante no campo científico, com capital simbólico acumulado e que, devido ao capital social decorrente de ligações com familiares do recém-eleito presidente, foi indicado para o cargo. 
O chefe da Divisão apresentava alto capital burocrático e baixo capital científico, mesmo com inserção neste campo (Figura 11).

Os profissionais que participaram do grupo técnico cientifico da DNSB apresentaram capital científico alto ou muito alto, dentre aqueles pertencentes à Aboprev. Quanto ao capital político, aqueles com maior acumulação eram vinculados ao subespaço de crítica, geralmente vinculados a partidos de esquerda. Dentre os consultores, um deles era filiado ao PMDB. A maioria dos consultores e o coordenador de saúde bucal não apresentavam filiação partidária (Quadro 11).

Como a maioria dos entrevistados apresentava relação com a DNSB/Coordenação ou exercia cargos burocráticos em outras esferas, também se percebe acumulação mediana de capital burocrático. Dentre os consultores, acrescentou-se Sylvio Palermo Gevaerd, representado pela letra A3, ${ }^{80}$ que não foi entrevistado, mas exerceu papel importante no espaço de formulação das políticas. O grupo de consultores pertencente à Aboprev apresentou capital científico alto ou muito alto.

O polo dominante no espaço de formulação das políticas de saúde bucal era formado pelo Diretor da DNSB e seus consultores também ligados à Aboprev. Estes apresentavam maior volume global de capital (Quadro 12).

Já os grupos de contestação e crítica das políticas como o MBRO, no início da década, mais especificamente através dos Enatespo, entre 1990 e 1993, apresentavam capital político médio, alto e capital burocrático médio. A aproximação neste grupo se deu através das disposições políticas, como participação em partidos políticos, em movimentos estudantis e em movimentos pela democracia.

Os entrevistados que se posicionaram a favor da fluoretação do sal, assim como outros dentistas, como Mário Chaves $(\mathrm{A} 1)^{1}$ e Paulo Freire (A2), ${ }^{1}$ possuíam capital burocrático médio ou muito alto e capital político médio. Os dentistas que participavam da Rede Cedros, favoráveis à fluoretação do sal, ocupavam posições variadas no espaço, apresentando capitais distintos. Quando se analisa os agentes da Aboprev, que foram inicialmente favoráveis, conforme registrado em publicações da Associação, mas depois se declararam contrários à fluoretação do sal de cozinha devido a análises por membros que também eram consultores do MS, segundo seus capitais burocrático e científico, observa-se alto capital científico e burocrático mediano.

80 Sylvio Palermo Gevaerd, Mário de Magalhães Chaves e Paulo Freire são falecidos e não par ticiparam do estudo através de entrevistas, entretanto, suas trajetórias foram analisadas por meio de biografias disponibilizadas, informações em outras entrevistas, material publicado e currículo Lattes, no caso de Sylvio Palermo Gevaerd. Para mapear as tomadas de posição, foram analisadas publicações assim como as entrevistas concedidas por pares descritos na metodologia. 


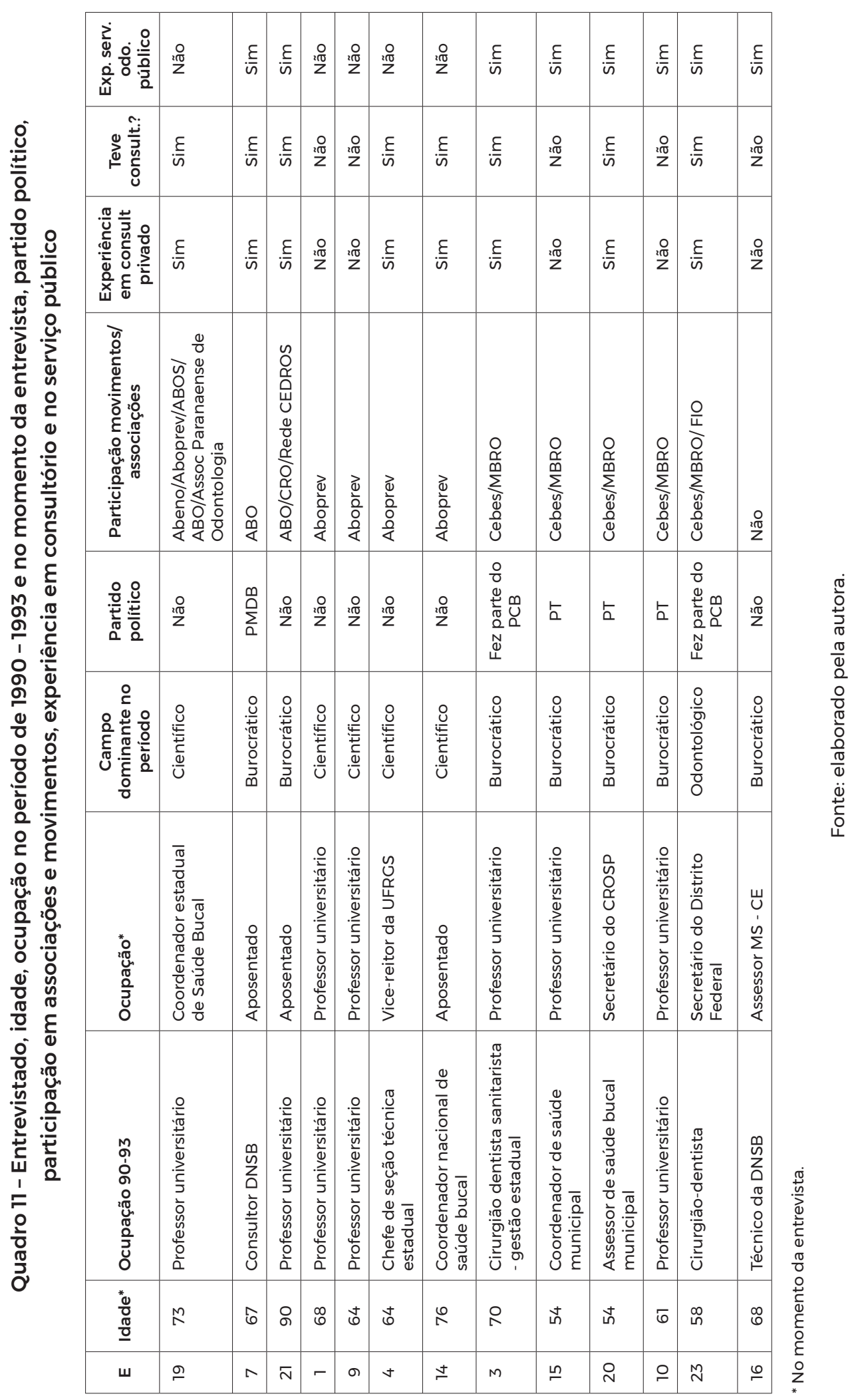




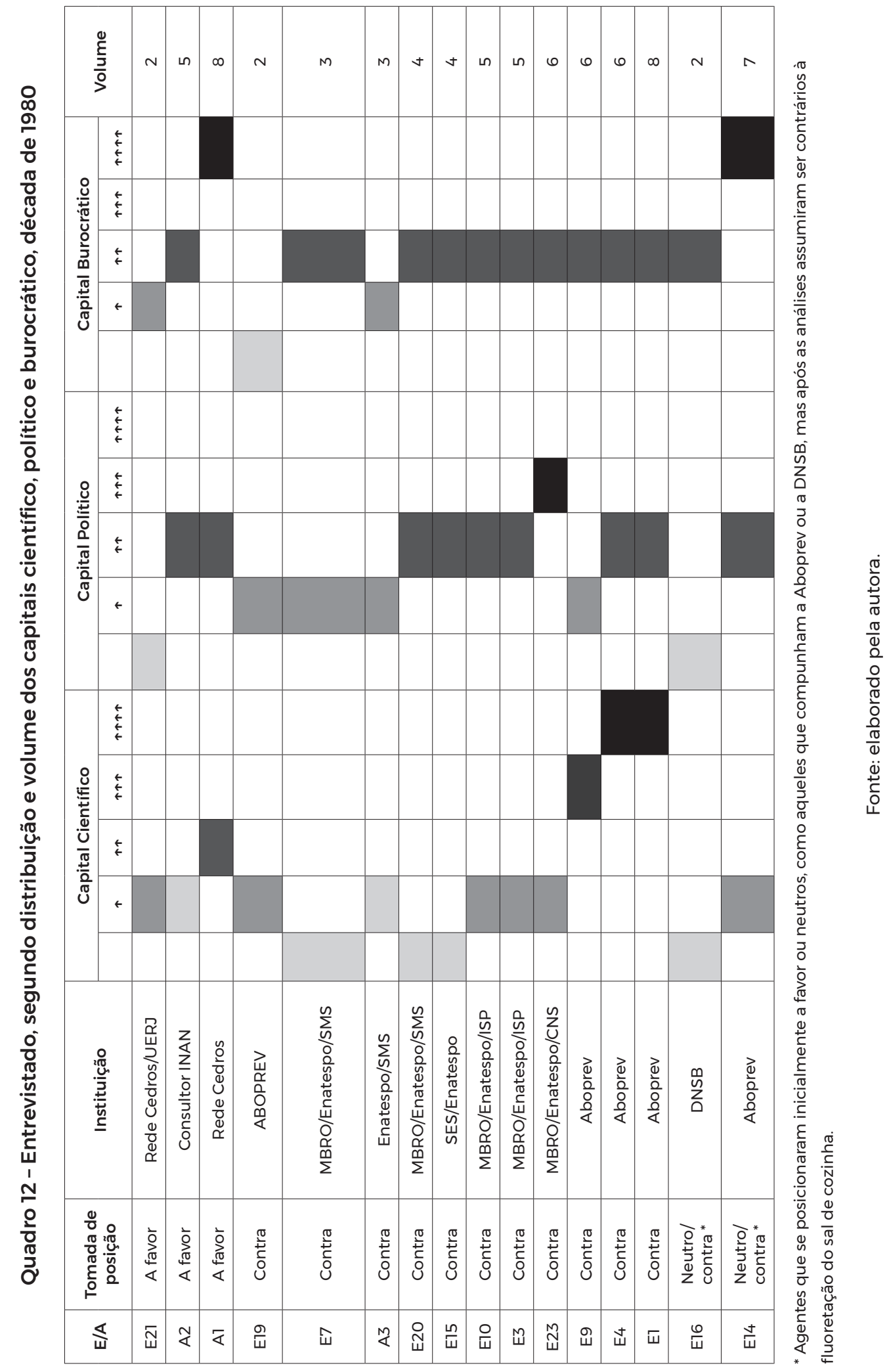


Figura 11 - Agentes participantes do espaço de formulação de crítica das políticas de saúde bucal segundo capitais burocrático e científico, 1990-1993

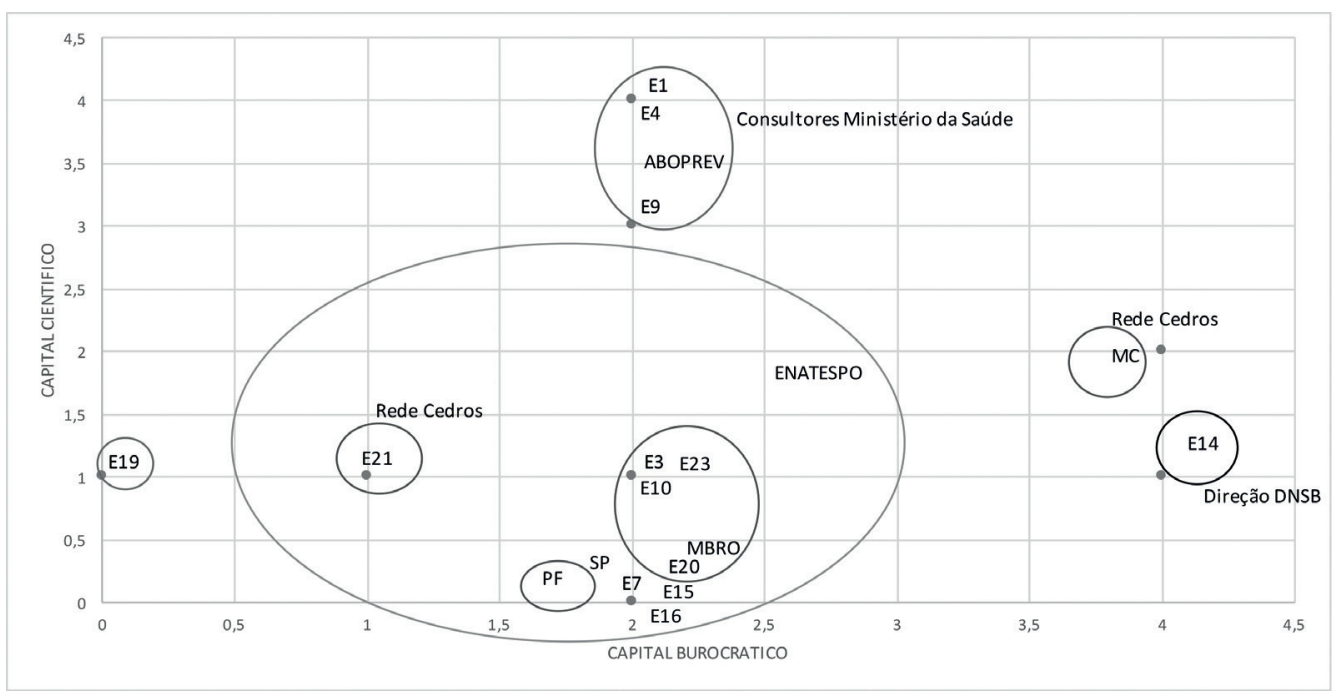

Fonte: Elaborado pela autora.

Figura 12 - Agentes participantes do espaço de formulação de crítica das políticas de saúde bucal, segundo capitais burocrático e político, 1990-1993

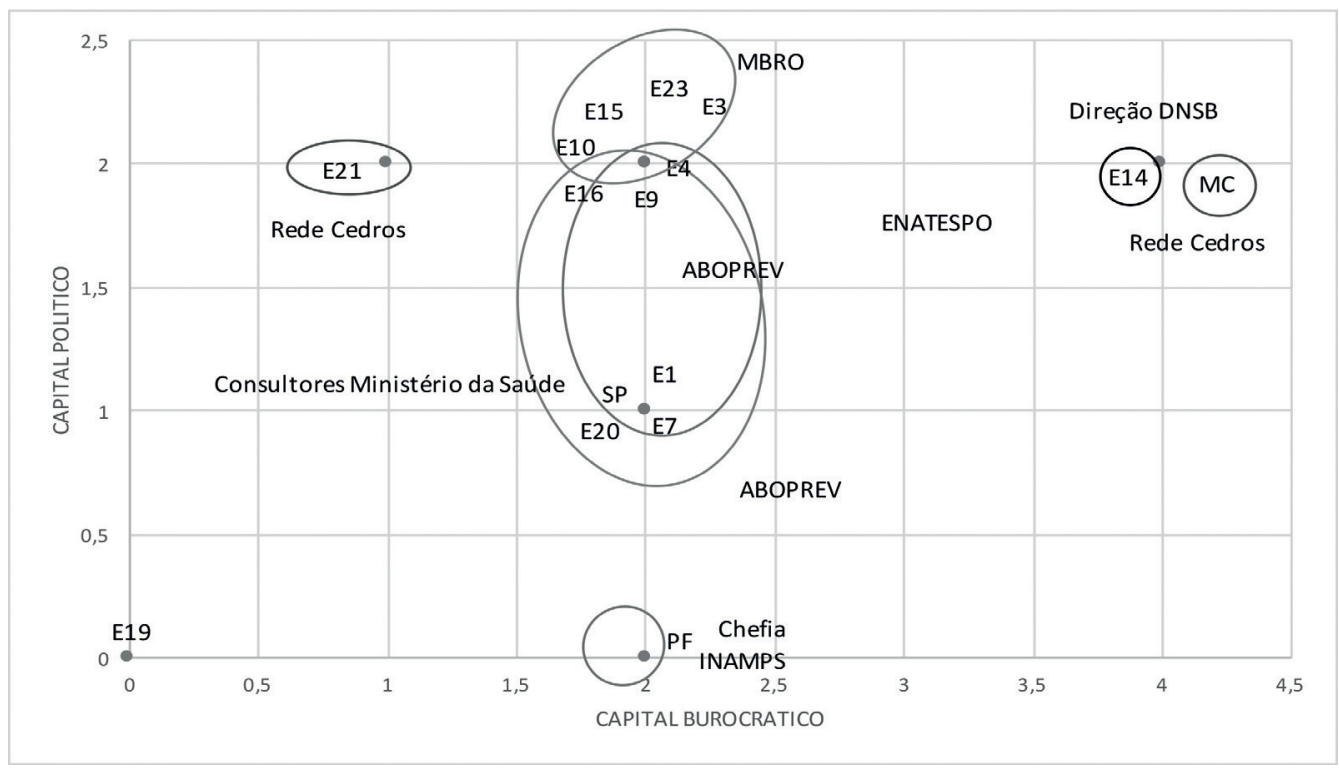

Fonte: elaborado pela autora. 
Figura 13 - Agentes participantes do espaço de formulação de crítica das políticas de saúde bucal, segundo capitais científico e político, 1990-1993

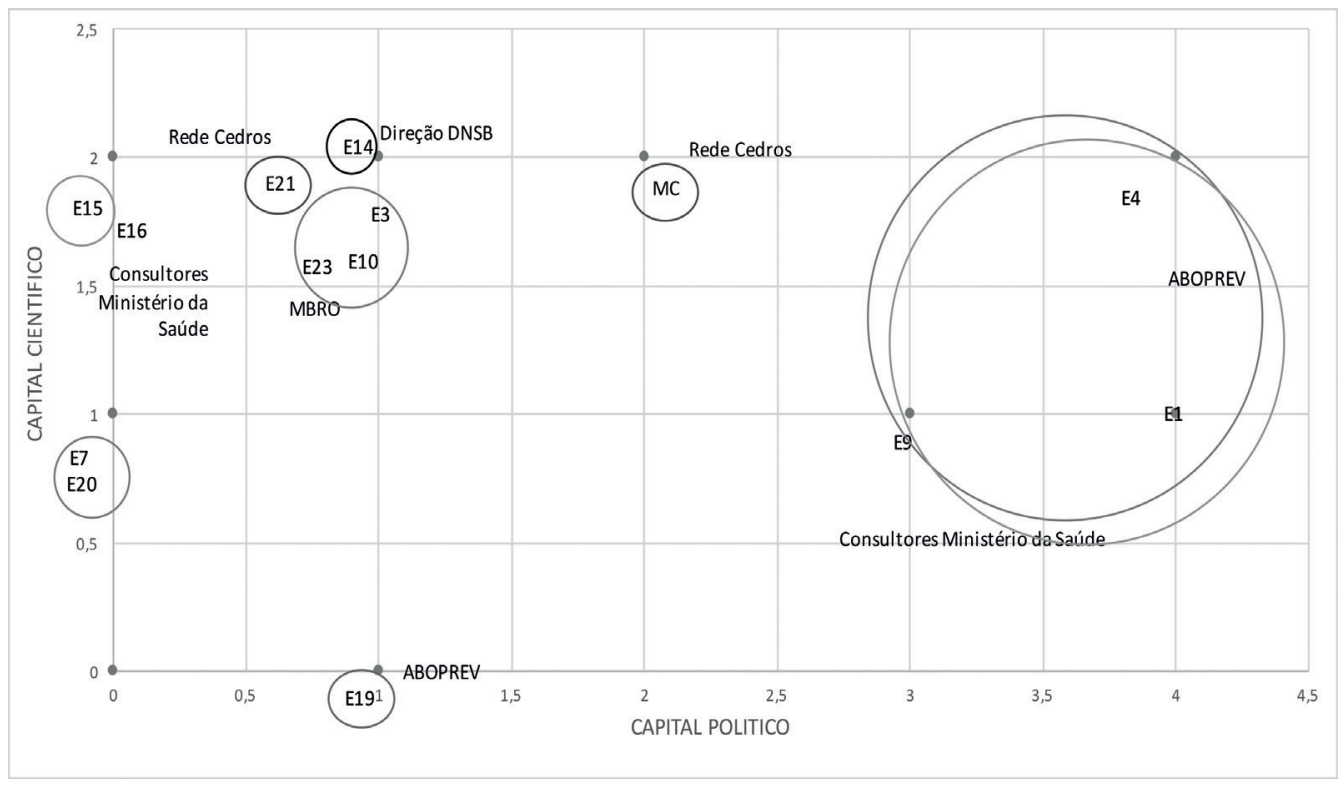

Fonte: elaborado pela autora.

Observou-se, também, diversidade na acumulação desses capitais dentre aqueles que participavam de movimentos contra hegemônicos, como o MBRO e os Enatespo, declaradamente contrários à política (Figura 11). O espaço de relações se modifica quando se analisa os capitais burocrático e político. Os membros da Rede Cedros apresentam similaridade, com capital burocrático muito baixo e político baixo ou médio. A mesma diversidade foi constatada entre membros do Enatespo, MBRO e Rede Cedros na análise entre os capitais científico e político. Quanto àqueles da Aboprev que eram consultores do Ministério da Saúde observou-se nova semelhança, com alto capital científico e político mediano.

Observou-se que o grupo dos dentistas que sempre se posicionou como contrário à fluoretação do sal e participava de movimentos críticos quanto à política, apresentava trajetória ascendente e concepção de SUS democrático, conforme classificação elaborada por Paim (2009). A maioria destes teve trajetória ligada à saúde pública através da formação pós-graduada ou experiência no serviço público. Já no grupo que foi favorável à política, inicialmente, ou mostrou neutralidade inicial e depois apresentou tomada de posição contrária à fluoretação do sal, muitos apresentaram concepções referentes ao SUS formal com o sentido de trajetória estável e origem de classe média. O entrevistado que foi favorável à política desde o início, defendendo sua implementação no nível nacional em locais selecionados, 
apresentou concepção de SUS formal, trajetória estável com ponto de partida de classe média.

A posição na fratria, o local onde cursou o segundo grau e a macrorregião de nascimento não apresentou distinções entre os grupos. Os indivíduos que participaram ou influenciaram a formulação das políticas de 1990 a 1993 eram nascidos no Nordeste, Sudeste ou Sul. Conforme já referido, todos os dentistas que participaram dos movimentos ou eventos de críticas à política haviam participado do movimento estudantil. Já o entrevistado favorável à política não apresentou a referida participação. No grupo da Aboprev, com publicações iniciais favoráveis à política, mas críticas severas após análise e tomadas de posição contrária, não existiu homogeneidade.

No sociograma, representa-se os agentes segundo tomadas de posição e capital político. Encontram-se à direita, aqueles favoráveis à fluoretação do sal de cozinha, inclusive algumas entidades de classe, como a ABO e o CFO, além da Rede Cedros. À esquerda, em posição contrária, localizou-se o grupo dos movimentos de crítica, como Enatespo e Cebes. Ao centro, estão representados a DNSB e os consultores da Aboprev que, inicialmente, se manifestaram como neutros, mas depois se declararam contrários (Figura 14).

Através das análises das mil palavras mais frequentes com cinco, seis, sete, nove, dez e onze letras nas entrevistas realizadas, foi possível observar, novamente, uma predominância da palavra "saúde", com frequência maior que oral ou bucal. Em contraposição, aparece em, praticamente, todos os diagramas dente, dentista, odontológico, revelando a ênfase no dente. Em seguida, nas palavras com seis e sete letras aparecem procedimentos e fluoretação, o que pode corresponder, por um lado, à introdução dessa nova categoria - procedimentos coletivos, e, por outro, refletir a polêmica existente sobre a fluoretação naquele momento. Nomes como Sérgio Weyne, então coordenador, no início da década de 1990, Vitor Gomes Pinto, coordenador até 1989, e Paulo Capel Narvai, do MBRO e Enatespo, aparecem em segundo plano. Aboprev, biofilme, flúor, restauração, prevenção, criança, cariosa, desmineralização e remineralização deram conta de uma parte das propostas de origem escandinava defendidas pela Aboprev e na nova política também aparecem em segundo plano, mas também são consistentes com os debates acima analisados (Figura 15).

Outra palavra muito proferida pelos entrevistados foi Odontologia, apesar do termo saúde bucal já estar em uso nesse período. Isso pode estar relacionado à opção teórica da Aboprev de Odontologia Preventiva que norteou as ações da DNSB da época. 


\section{Quadro 13 - Entrevistado, concepção do SUS, origem social, sentido da trajetória, colégio secundário, macrorregião de nascimento, participação em movimento estudantil}

\begin{tabular}{|c|c|c|c|c|c|c|c|}
\hline E & $\begin{array}{c}\text { Tomada } \\
\text { de posição }\end{array}$ & Concepção SUS & $\begin{array}{c}\text { Origem } \\
\text { social }\end{array}$ & $\begin{array}{c}\text { Sentido da } \\
\text { trajetória }\end{array}$ & $\begin{array}{c}\text { Colégio } \\
\text { secundário }\end{array}$ & Região & $\begin{array}{c}\text { Movimento } \\
\text { estudantil }\end{array}$ \\
\hline 23 & Contra & SUS democrático & Popular & Ascendente & Público & Nordeste & Não \\
\hline 20 & Contra & SUS democrático & Popular & Ascendente & Privado & Sudeste & Sim \\
\hline 19 & Contra & SUS democrático & Popular & Ascendente & Público & Sul & Sim \\
\hline 10 & Contra & SUS democrático & Popular & Ascendente & Público & Sul & Sim \\
\hline 9 & Contra & SUS formal & Popular & Ascendente & Público & Sul & Sim \\
\hline 7 & Contra & SUS democrático & Popular & Ascendente & Privado & Sudeste & Sim \\
\hline 4 & Contra & SUS democrático & Popular & Ascendente & Público & Sul & Sim \\
\hline 3 & Contra & SUS democrático & Popular & Ascendente & Público & Sudeste & Sim \\
\hline 1 & Contra & SUS formal & Popular & Ascendente & SI & Sul & Não \\
\hline 21 & A favor & SUS formal & Média & Estável & Privado & Nordeste & Não \\
\hline 16 & $\begin{array}{l}\text { Neutro/ } \\
\text { contra* }\end{array}$ & SUS formal & Média & Estável & Público & Nordeste & Sim \\
\hline 15 & Contra & SUS democrático & Média & Estável & Público & Sul & SI \\
\hline 14 & $\begin{array}{l}\text { Neutro/ } \\
\text { contra* }\end{array}$ & SUS formal & Média & Estável & Privado & Nordeste & Não \\
\hline
\end{tabular}

* Inicialmente neutros, mas após contrários

Fonte: elaborado pela autora.

Figura 14 - Sociograma referente ao espaço de formulação das políticas de saúde bucal, início da década de 1990

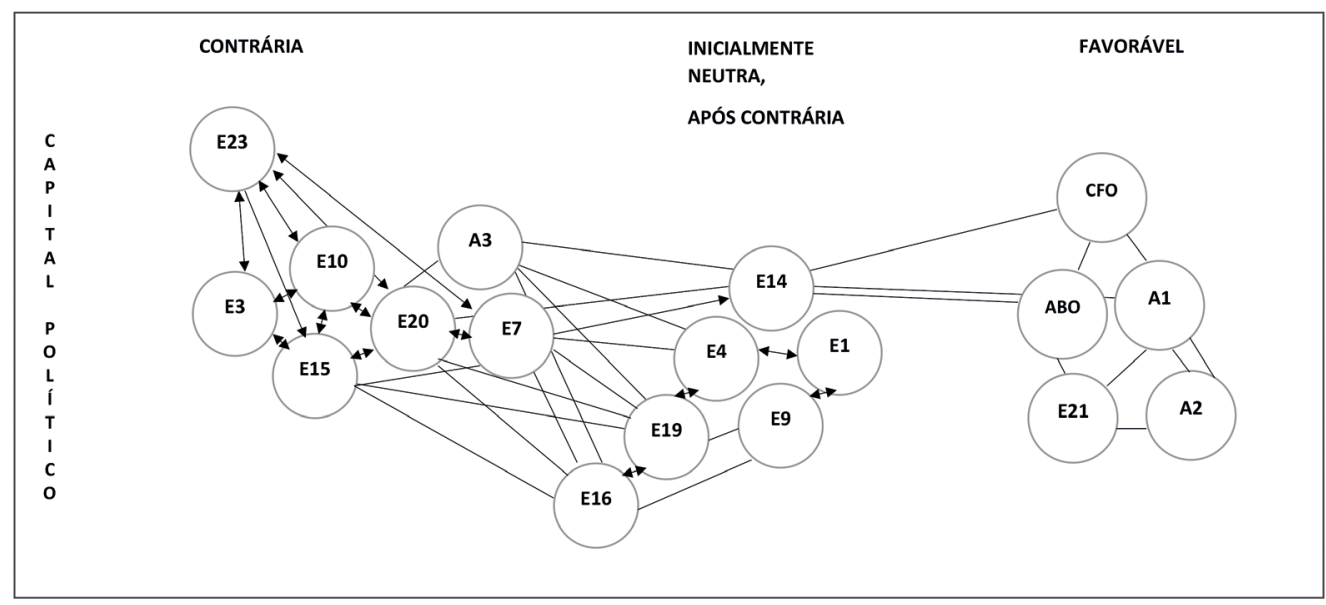

Fonte: elaborado pela autora. 
Figura 15 - Palavras mais frequentes a partir de cinco, seis, sete, nove, dez e onze letras
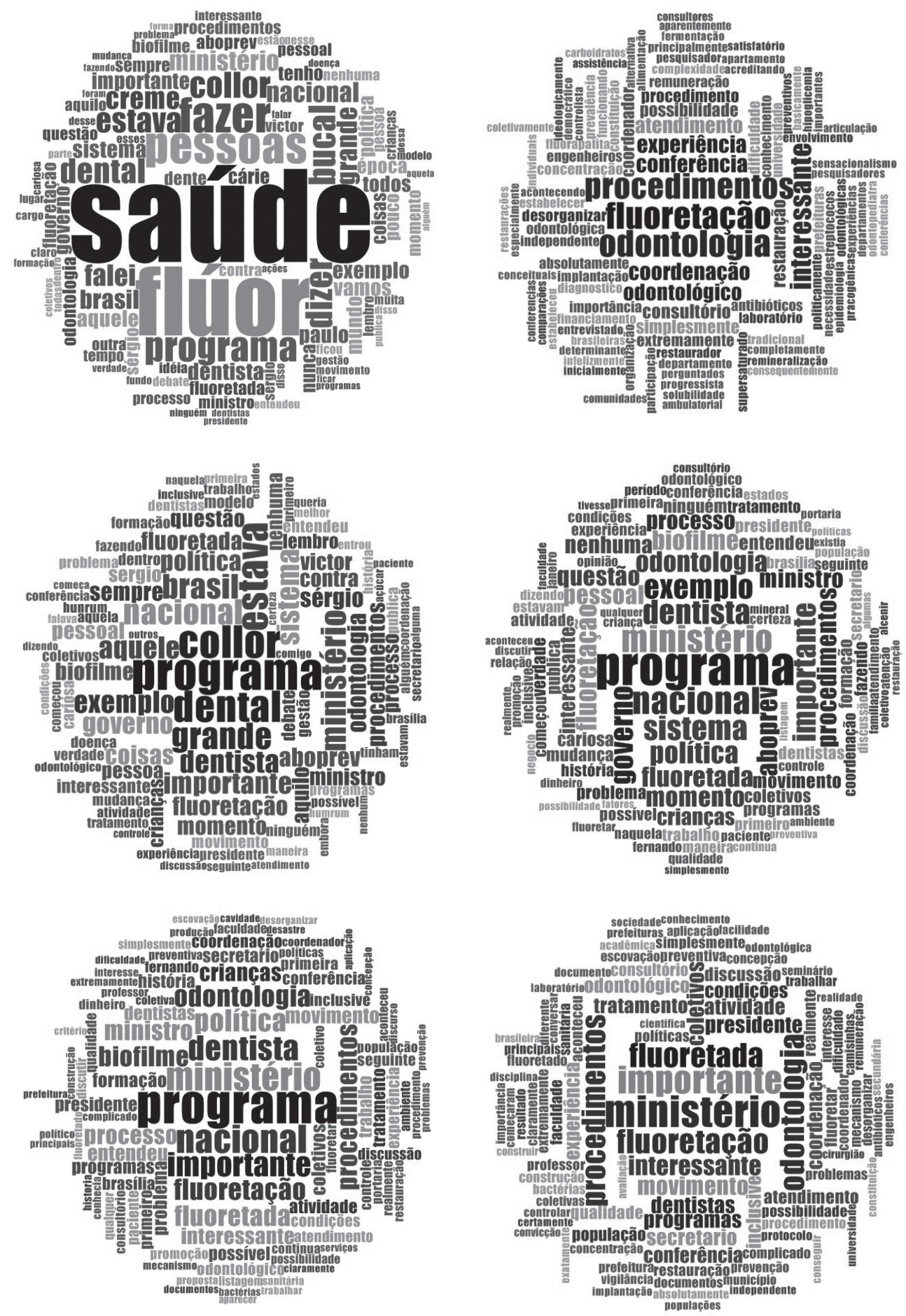

Fonte: elaborado pela autora. 


\section{Procedimentos coletivos no decorrer da década de 1990}

Conforme referido no capítulo anterior, a cirurgiã-dentista Sônia Maria Dantas de Souza assumiu a coordenação de saúde bucal, em setembro de 1995. Após José Carlos Cativo Gedeão ter deixado o cargo, o setor permaneceu sem uma liderança por alguns meses. Em entrevista, Sonia Dantas ${ }^{81}$ explicou que o convite para a vinda ao Ministério da Saúde (MS) foi feito pelo dr. Gerson Oliveira Penna $^{82}$ que foi assessor do ministro Adib Jatene. Para assumir a coordenação de saúde bucal, o convite foi feito pela dra. Neide Glória Garrido, secretária de Assistência à Saúde do Ministério da Saúde, com a aquiescência de Gerson Penna.

Quando assumiu a coordenação de Saúde Bucal, Sônia Dantas ${ }^{83}$ sofreu preconceito por ser mulher em uma profissão eminentemente masculina. Oriunda do Norte do país, em cargo, anteriormente, apenas ocupado por homens com reconhecimento científico ou burocrático, a então coordenadora nacional não pertencia ao campo científico, possuía especialização em Saúde Pública e construiu sua carreira no campo burocrático no estado do Pará, ou seja, as diferenças dos dentistas que ocuparam o cargo anteriormente eram de gênero, região e capital científico, bem como não apresentavam o acúmulo de capital simbólico daqueles que a antecederam. Havia também a oposição técnico x político na qual a profissional

81 Sonia Maria Dantas de Souza, entrevista concedida à autora, Brasília, 2014.

82 Gerson Oliveira Penna é graduado em Medicina pela Universidade Federal do Pará (UFPA) (1984). Titulado como especialista em Dermatologia pela Sociedade Brasileira de Dermatologia/AMB (1988), especialista em Planejamento Estratégico (1992), doutor em Medicina Tropical, pela UnB (2002). Vice-presidente eleito da Sociedade Brasileira de Dermatologia e presidente do Congresso Brasileiro de Dermatologia (2006). Fundador e ex-diretor do Centro Nacional de Epidemiologia do Ministério da Saúde. Foi assessor especial do ministro Adib Jatene, consultor da Organização Pan-Americana da Saúde, consultor da Organização Mundial da Saúde (OMS) e consultor do Programa das Nações Unidas para o Desenvolvimento. É do Editorial Board do Leprosy Review, único periódico indexado sobre o assunto no Med Line. Foi secretário de Estado de Vigilância em Saúde do Ministério da Saúde e presidente do Conselho Consultivo da Agência Nacional de Vigilância Sanitária. Médico e pesquisador colaborador pleno do Núcleo de Medicina Tropical, da UnB e pesquisador associado do Centro de Referência Nacional em Dermatologia (Fortaleza - CE). Investigador Principal do Ensaio Clínico Randomizado, estudo independente para determinar a efetividade do esquema Uniforme de MDT de seis doses (U-MDT) em pacientes de hanseníase (U-MDT/RCT-BR), financiado pelo Departamento de Ciência e Tecnologia (Decit) do Conselho Nacional de Desenvolvimento Científico e Tecnológico (CNPq). Pós-doutorando no Instituto de Saúde Coletiva da Universidade Federal da Bahia (ISC/UFBA).

83 Como a cirurgiã-dentista veio ao Ministério da Saúde inicialmente para assumir outro cargo, a Portaria $n^{\circ}$ 1669, de 25 de agosto de 1995, publicada no DOU, de 28 de agosto de 1995, nomeava Sonia Maria Dantas de Souza para exercer cargo em comissão de coordenadora da Coordenação Geral de Atenção a Grupos Populacionais e Atividades Sistêmicas. Apesar de ter assumido a coordenação de saúde bucal neste período, não foram encontradas portarias no diário oficial atualizando sua lotação em 1995. 
se situava no campo técnico, característica do campo burocrático, que corresponde ao desinteresse material ou político e o interesse no universal, no público, ou seja, com o SUS, com a saúde pública.

A estrutura da Coordenação Nacional de Saúde Bucal da Secretaria de Projetos Especiais se manteve a mesma da DNSB: dois técnicos que vinham participando desde o GT-Odonto, Mércio de Azevedo Ferreira e Benedito Elias Waquim, uma secretária e a coordenadora. Apesar de o entrevistado afirmar que as políticas anteriores foram utilizadas, os documentos anteriores permaneceram como projetos distantes. A coordenação da segunda metade da década de 1990 tinha como meta uma nova redação para a política nacional, entretanto, esta não foi concretizada. Os documentos da II CNSB e dos Enatespo foram mencionados como norteadores das ações.

Os PC passaram por revisões contínuas. Estudo realizado em 1995, pela Coordenação, que analisou os procedimentos coletivos no segundo semestre de 1994 e no primeiro semestre de 1995, apontou baixa cobertura populacional, falta de registro, aumento exagerado de determinados procedimentos em relação ao mês anterior e Unidades Federadas que realizavam pouquíssimos PC. (BRASIL, 1995) Neste documento, recomendava-se apresentar a situação nas reuniões das Comissões Intergestores Bipartite (CIB), no sentido de minimizar os problemas encontrados, oferecer instrumentos às coordenações estaduais, apoiar os estados a apresentarem melhor desempenho e definirem o encaminhamento da produção mensal à coordenação nacional. (BRASIL, 1995)

No trabalho citado, verificou-se disparidades na quantidade de recursos recebida pelos estados. Destaca-se as grandes quantias recebidas pelos estados de Pernambuco, Mato Grosso do Sul, Minas Gerais, São Paulo, Paraná e Santa Catarina, no segundo semestre de 1994 e 1995 . Essas análises ficavam a cargo do comitê de especialistas voltadas para o Sistema de Informação. Um dos dentistas que integrava esta parte do Comitê foi João Antônio Neto Caminha. ${ }^{84}$

Os PC II e III foram excluídos da tabela de procedimentos SIA/SUS, ${ }^{85} \mathrm{em} 1997$, sendo concatenados em apenas um procedimento coletivo. Em portaria ${ }^{86}$ subsequente, da Secretaria de Assistência à Saúde, os PC aparecem unificados, inte-

84 João Antônio Neto Caminha é cirurgião-dentista, possui mestrado em Odontologia pela UFRGS (1981). Foi diretor-presidente do Fundação de Apoio à UFRGS. Tem experiência na área de Odontologia, com ênfase em Odontologia Social e Preventiva - informações extraídas do currículo Lattes.

85 Portaria MS/GM n 1.889, de 18 de dezembro de 1997, publicada no DOU, de 22 de dezembro de 1997.

Portaria $n^{\circ} 166$, de 31 de dezembro de 1997, publicada no DOU, de 20 de janeiro de 1998. 
grando o Piso da Atenção Básica (PAB) como um "conjunto de procedimentos de promoção e prevenção em saúde bucal, de baixa complexidade, dispensando equipamentos odontológicos, desenvolvidos integralmente em grupos populacionais previamente identificados”. (BRASIL, 1998)

Outra justificativa para as modificações no PC foram visitas realizadas pela coordenadora de saúde bucal e sua equipe aos municípios, onde foi percebido que o levantamento epidemiológico não era realizado, mas todos recebiam como se tivesse sido feito. Ela e a equipe constatavam que o procedimento mais realizado eram as escovações supervisionadas, entretanto, sem controle da periodicidade e na distribuição das escovas e dentifrícios. Assim, a unificação dos PC visava minimizar essas distorções. 


\section{INSERÇÃO DA SAÚDE BUCAL NO PROGRAMA SAÚDE DA FAMÍLIA}

O Programa Saúde da Família (PSF) foi instituído em dezembro de 1993, baseado em algumas experiências exitosas municipais que estavam em curso no Brasil. (BRASIL, 2012) A implantação do Programa é um marco na incorporação das estratégias de atenção primária no sistema de saúde brasileiro, preconizando mudanças no âmbito organizacional do modelo de atenção vigente. (ESCOREL et al., 2007)

A inclusão da saúde bucal na saúde da família ocorreu em 2000, na gestão de Sônia Maria Dantas de Souza, com forte articulação das entidades de classe com deputados e da Federação Interestadual dos Odontologistas (FIO) e apoio da coordenação e diretoria do Departamento de Atenção Básica. O Boletim da entidade retrata a luta empreendida para a chamada "vitória histórica da Odontologia" em 2000.

O primeiro registro de tentativa de inclusão foi em abril de 1994, quando Swendenberger do Nascimento Barbosa, então presidente da FIO, entregou documento reivindicando a inserção da saúde bucal no recém-criado PSF ao ministro da Saúde Henrique Santilho. O movimento foi apoiado pelas Secretarias Municipais de Saúde de Curitiba e Maceió, da Secretaria Estadual de São Paulo, da Fundação Nacional de Saúde assim como pelos professores Paulo Capel Narvai, da USP, e Jorge Cordón, da UnB. (BOLETIM DA FEDERAÇÃO INTERESTADUAL DOS ODONTOLOGISTAS, 2000)

Há divergências nos discursos quanto à inclusão na agenda. Segundo a gestora da Coordenação de Saúde Bucal (Cosab), em 1995, buscou-se inserir uma pauta na agenda do Ministério da Saúde, através da Atenção Básica, sobre a inclusão da saúde bucal no PSF, mas não se obteve êxito. Desta forma, passou a ocupar-se de outros temas relevantes como a fluoretação das águas e o inquérito epidemiológico. Já gestores que atuavam no Departamento de Atenção Básica 
(DAB) afirmaram que a inclusão da ESB no Programa foi pautada pelos profissionais que atuavam no $\mathrm{DAB}$ devido à experiência exitosa de projetos pilotos em municípios, o que gerou um chamamento para que a Cosab atuasse neste sentido. A inclusão da saúde bucal na equipe mínima foi justificada no DAB pela especificidade do objeto de trabalho que não poderia ser reproduzido pelo(a) médico(a) ou enfermeiro(a).

No ano de 1996, foram realizados o levantamento da situação das águas de abastecimento público no país e lançado o livro Fluoretação das águas: Manual de orientação prática, de autoria de Osvaldo Carro Buendia. ${ }^{87} \mathrm{O}$ livro foi oriundo de cooperação técnica com as Nações Unidas e abordava considerações gerais sobre o flúor, concepção de cárie, informações técnicas para fluoretação das águas com distintos materiais e em localidades como zonas rurais, escolas e, por fim, tratava da análise do teor residual do flúor e de como realizar as compras por órgãos públicos, com vistas à fluoretação das águas. (BUENDIA, 1996)

Ainda no ano de 1996, realizou-se o segundo inquérito epidemiológico em Saúde Bucal, dez anos após a realização do primeiro inquérito epidemiológico. O levantamento foi desenhado por consultores da Cosab, como o prof. João Antônio Caminha e obteve o apoio dos CRO, ABO e Secretarias Estaduais de Saúde. O inquérito recebeu muitas críticas quanto à fidedignidade dos seus dados, como problemas no plano amostral e critérios, dentre outros. Essas críticas foram discutidas no XIV Enatespo em Fortaleza (CE). (OLIVEIRA, 1998) O trabalho pesquisou apenas cárie dentária em escolares de 6 a 12 anos, em zona urbana de 27 capitais e do Distrito Federal. A pesquisa mostrou tendência de redução da cárie dentária na população escolar com CPO-D de 3,06 aos 12 anos quando comparado ao CPO-D de 6,65 em 1986, na mesma idade, e persistência das desigualdades regionais.

No ano seguinte, em outubro de 1997, foi lançado um documento no qual os esforços estiveram voltados, novamente, para as práticas de saúde bucal na saúde da família, desta vez direcionada para o Agente Comunitário de Saúde (ACS). (BRASIL, 1997) O manual seguia a política praticada no Ministério desenvolvida pelo DAB e buscava orientar o ACS em algumas situações específicas relaciona-

87 Osvaldo Carro Buendia era membro do grupo de especialistas em Prevenção das Doenças Bucais e consultor para Assistência à Fluoretação de Águas da CNSB do Ministério da Saúde. Foi secretário geral do Grupo Estadual de Controle da Fluoretação de Águas do Estado de São Paulo (Gecof-SP), da Secretaria de Estado da Saúde, sediado no Centro de Apoio ao Desenvolvimento da Assistência à Saúde Escolar. Professor titular de Odontologia Preventiva e Social do curso de Odontologia da Universidade Santo Amaro (UNISA), em São Paulo. Cirurgião-dentista sanitarista formado pela Faculdade de Saúde Pública da USP. (BUENDIA, 1996) 
das a doenças bucais, mas, também, era direcionado a ações educativas e preventivas.

O documento elencava dois grupos de atividades a serem desenvolvidas pelos ACS:

- educação/prevenção em saúde bucal; e

- detecção de problemas e encaminhamento adequado.

O primeiro grupo foi constituído por três atividades: educação em Saúde Bucal sobre as causas das principais doenças que afligem a cavidade bucal, consumo inteligente de açúcar, higiene bucal e autoexame; escovação supervisionada e bochechos fluorados. Já o segundo grupo tratava do encaminhamento de casos de odontalgias, hemorragias, abcessos, fraturas dentárias e ósseas, cavidades de cárie, sangramento gengival, lesões de mucosa e fendas palatinas/lábio leporino aos serviços de saúde. (BRASIL, 1997)

De acordo com o documento, o ACS seria responsável por explicar as principais doenças que atingem a cavidade bucal e os cuidados necessários para a sua prevenção. Outra função seria orientar os membros da família quanto à limpeza dos dentes e o uso de fio dental. Ademais, deveriam realizar escovações supervisionadas e bochechos fluorados com orientação de equipes odontológicas. Entretanto, o documento não retratou os aspectos operacionais de implementação da proposta. (BRASIL, 1997)

Ainda em 1997, no mês de outubro, foi publicada a Portaria que instituía o Comitê Técnico Científico (CTC) de assessoramento à Coordenação de Saúde Bucal constituído por João Antônio Neto Caminha, professor adjunto do Departamento de Odontologia Preventiva e Social da UFRGS; Jayme Aparecido Cury, professor titular de Bioquímica da Faculdade de Odontologia de Piracicaba (FOP)/UNICAMP; Djalmo Sanzi Souza, chefe da Divisão de Saúde Comunitária do Grupo Hospitalar Conceição; Paulo Capel Narvai, professor doutor da FSP/USP; e Sylvio Palermo Gevaerd, professor assistente de Odontologia Preventiva e Social da UFPR. A coordenadora Sônia Dantas foi atribuída a Secretaria Executiva do CTC. Paulo Capel Narvai foi votado e escolhido como representante para o CTC no XIII Enatespo, ocorrido no mesmo ano.

A escolha dos nomes para o Comitê Técnico Científico se baseou na expertise para os temas de fluoretação - Jayme Cury, Sistema de Informação; João Antônio Caminha Neto, Saúde Coletiva; Paulo Capel, Djalmo Sanzi e Sylvio Gevaerd. ${ }^{88}$

Segundo Sonia Maria Dantas de Souza, em entrevista à autora. 
Assim como as outras comissões constituídas anteriormente, de acordo com os entrevistados, o CTC trabalhava nas pautas elencadas pela coordenação, sem autonomia para a inclusão de outros temas. Ademais, os membros também representavam a coordenação em alguns debates, como Sylvio Gevaerd, nas discussões com a Agência Nacional de Saúde Suplementar (ANS); Antônio Caminha participou da elaboração de um Sistema de Informações em Saúde Bucal, específico, com procedimentos de Odontologia, que não foi implementado pelo Ministério da Saúde.

As discussões sobre a inclusão da saúde bucal no PSF continuaram a fazer parte dos Enatespo. O relatório final do XIV Enatespo, realizado em Fortaleza (CE), de 9 a 13 de agosto de 1998, apontava que a inclusão da saúde bucal na saúde da família deveria ser incentivada sem prejuízo das equipes existentes nas redes de serviços. Referia, também, o potencial da estratégia de mudança do modelo de atenção vigente. (ENATESPO, 1998)

No relatório final do Encontro, foi registrada moção de repúdio à coordenadora nacional de Saúde Bucal, afirmando que a profissional não representava o posicionamento dos trabalhadores do setor e referia, também, que ela era contrária ao desenvolvimento e fortalecimento do SUS. (ENATESPO, 1998)

No mesmo evento, ocorrido no ano seguinte, o XV Enatespo, realizado no período de 26 a 30 de setembro de 1999, no Rio de Janeiro (RJ), também se destacou a importância da referida inclusão, pois programas como o PACS e o PSF possibilitavam "[...] ir além das estratégias tradicionais restritas a determinados espaços sociais, ao privilegiar como local de atuação o território e a família”. (ENATESPO, 1999, p. 2) A plenária final reconheceu e afirmou a importância da inclusão dos profissionais da Odontologia que são o cirurgião-dentista, o auxiliar de Consultório Dentário, à época, hoje com a denominação de auxiliar em Saúde Bucal, e o técnico de Higiene Dental, atualmente técnico em Saúde Bucal, nas equipes do PSF. Ademais, foi recomendada a implementação de incentivo no PAB aos municípios que realizavam ações de saúde bucal no PACS ou no PSF. Paulo Capel Narvai e Djalmo Sanzi Souza participaram da relatoria do XV Enatespo. (ENATESPO, 1999)

O Boletim da FIO (1999) destacava a defesa do Enatespo pela inclusão de profissionais de Odontologia no PSF, não apenas o CD, mas, também, os auxiliares e técnicos, tendo a entidade sido representada no evento por José Carrijo Brom. A Federação também fez articulações em prol da inserção do projeto na agenda governamental. Segundo o Entrevistado 33, aliaram-se ao CFO, professores univer- 
sitários, a exemplo de Paulo Capel Narvai e Paulo Frazão, assim como pessoas do serviço, além do apoio de parlamentares.

A FIO, através da sua presidente Rozangela Camapum, juntamente com as entidades de classe, como o CFO, representado por Miguel Nobre, fizeram a articulação política com parlamentares que demandavam audiência com o Ministro da Saúde e apresentavam seu pleito. Também participaram do movimento pela inclusão da saúde bucal, a ABO, Conselhos Regionais de Odontologia, Academia Brasileira de Odontologia. Muitas vezes, a FIO orientava o CFO nas articulações políticas. Outras entidades que também participaram deste processo foram a Federação Nacional dos Odontologistas (FNO), através de sua vice-presidente, a cirurgiã-dentista Joana Batista Oliveira Lopes, e a ABO, representada pelo cirurgião-dentista dr. Norberto Francisco Lubiana.

O CTC foi convocado para elaboração da proposta de inclusão da saúde bucal na saúde da família. Membros do comitê estiveram à frente da concepção do documento, como Djalmo Sanzi Souza, Paulo Capel Narvai e Sylvio Palermo Gevaerd. O documento passou por algumas revisões e versões, tendo sofrido mudanças ao longo do processo de pactuações. O primeiro esboço da proposta data de abril de 2000; a primeira revisão do documento com memória de cálculo, de agosto do mesmo ano; e a última versão, próxima daquela publicada em Portaria, em outubro de 2000 (Quadro 14). Entretanto, dentre alguns aspectos não planejados no âmbito do CTC, o principal não aceito pelo ministro foi a paridade entre equipe de saúde da família e saúde bucal. Neste mesmo ano, a Cosab passou a se denominar Área Técnica de Saúde Bucal (ATSB) devido a mudanças na estrutura do Ministério da Saúde.

As coordenações estaduais também foram convocadas para discutir a proposta a fim de relatar suas experiências no Programa de Saúde da Família. Existiam muitos municípios com experiências exitosas (CALADO, 2002), contudo, em muitos estados brasileiros, as experiências estavam em seu início ou sequer haviam iniciado.

Outro fato se somou aos esforços do CTC, da coordenação da ATSB, às manifestações através dos Enatespo, da frente de articulação da FIO com o CFO e outras entidades odontológicas, pela publicação da PNAD do IBGE. Em julho de 2000, o ministro da Saúde, dr. José Serra, declarou seu interesse em estudar a inclusão do dentista no PSF, a partir dos resultados da PNAD que apontava o quantitativo de 30 milhões de brasileiros sem acesso aos serviços odontológicos no Brasil. (TRINTA..., 2000) 
As enfermeiras Heloisa Machado e Maria Fatima de Sousa que exerciam a gestão da Atenção Básica no Ministério da Saúde apoiaram a entrada da saúde bucal no PSF. Os três documentos de formulação da entrada da saúde bucal no PSF apresentam distinções. O primeiro documento, de abril de 2000, apresentava três modalidades: a primeira de adesão transitória de capacitação dos ACS para desenvolver ações voltadas à educação em saúde com ênfase na saúde bucal; a segunda seria uma etapa intermediária, apenas com o cirurgião-dentista na equipe mínima; e a terceira modalidade, denominada de adesão avançada, contaria com a equipe completa de saúde bucal, o CD, o ACD e o THD. A partir da segunda proposta, de agosto de 2000, a etapa de adesão é suprimida e a modalidade intermediária inclui o ACD, ficando a modalidade avançada com a equipe completa (Quadro 14). (BRASIL, 2000a, 2000b, 2000d).

Na terceira proposta, de outubro de 2000 , mais próxima do texto que consta na Portaria $\mathrm{n}^{\circ} 267$, de 6 de março de 2001, publicada no DOU em 7 de março de 2001, constam as modalidades I e II com a supressão dos termos intermediária e avançado. Quanto à redação dos objetivos, na Portaria publicada constam: melhorar as condições de saúde bucal da população brasileira; orientar as práticas de atenção à saúde bucal, consoante ao preconizado pelo PSF; assegurar o acesso progressivo de todas as famílias residentes nas áreas cobertas pelas equipes de saúde da família às ações de promoção e de prevenção bem como àquelas de caráter curativo-restauradoras de saúde bucal; capacitar, formar e educar permanentemente os profissionais de saúde bucal necessários ao PSF, por intermédio da articulação entre as instituições de ensino superior e as de serviço do SUS; e avaliar os padrões de qualidade e o impacto das ações de saúde bucal desenvolvidas, de acordo com os princípios do PSF. (BRASIL, 2000a, 2000b, 2000d) 


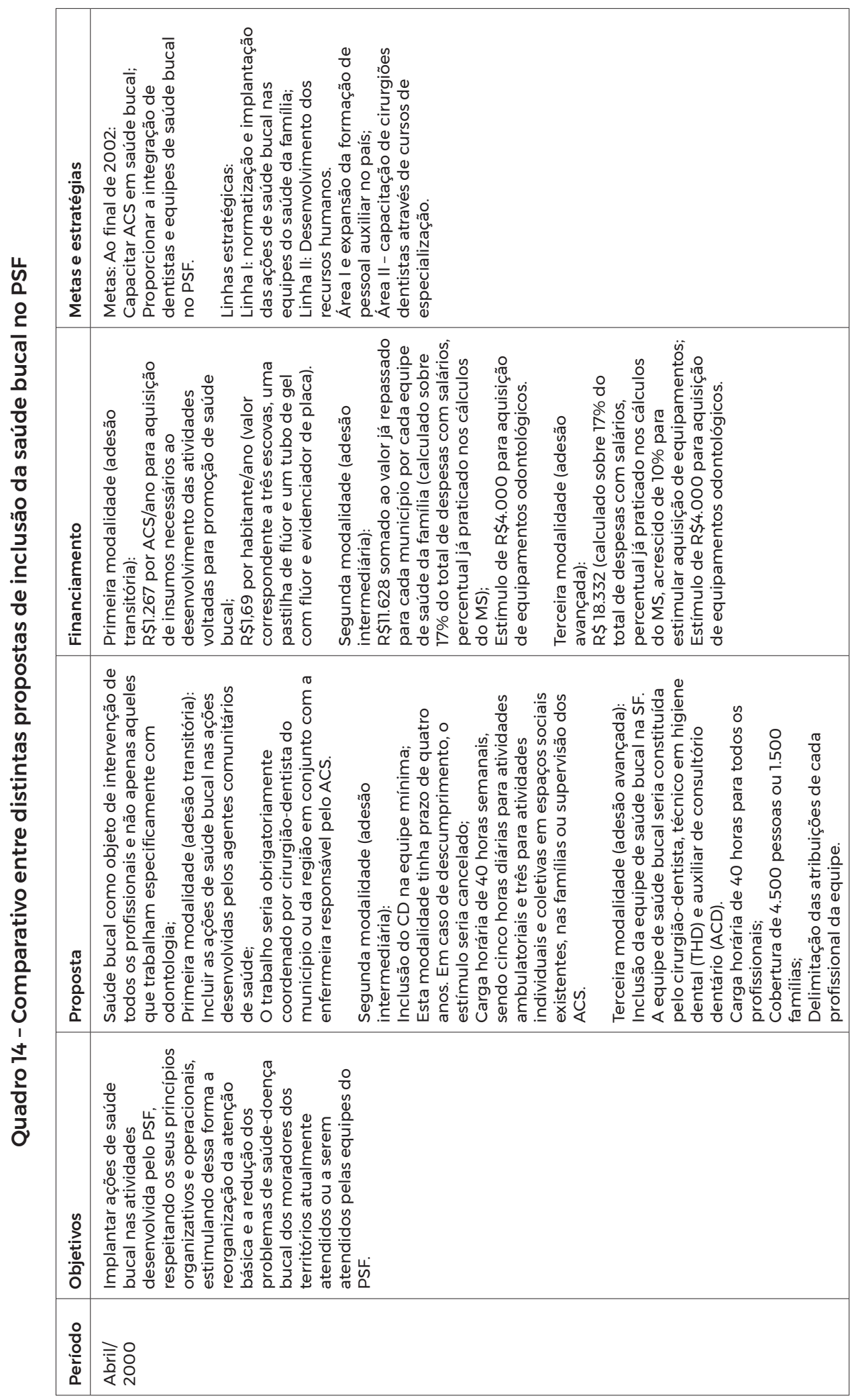




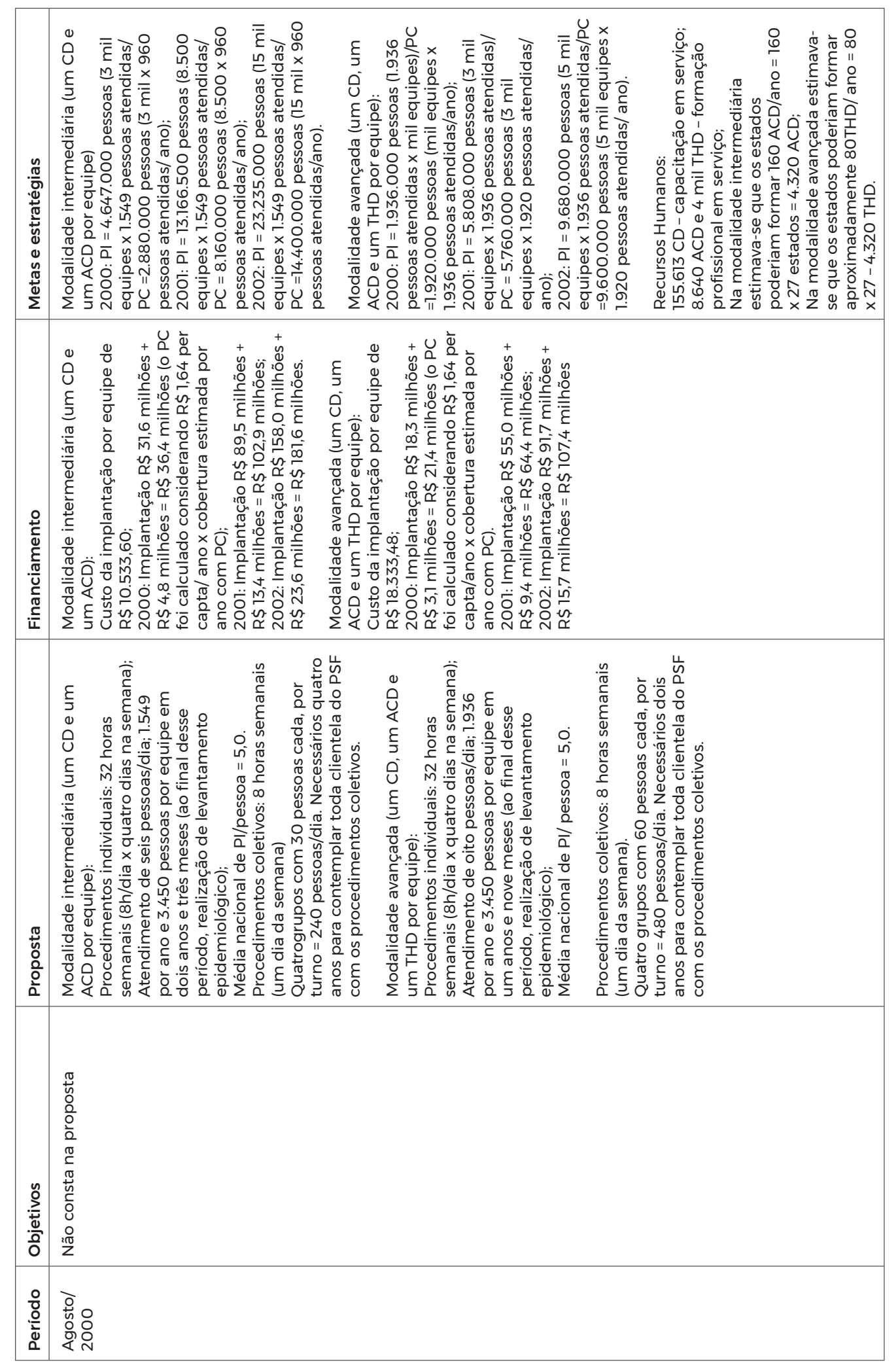




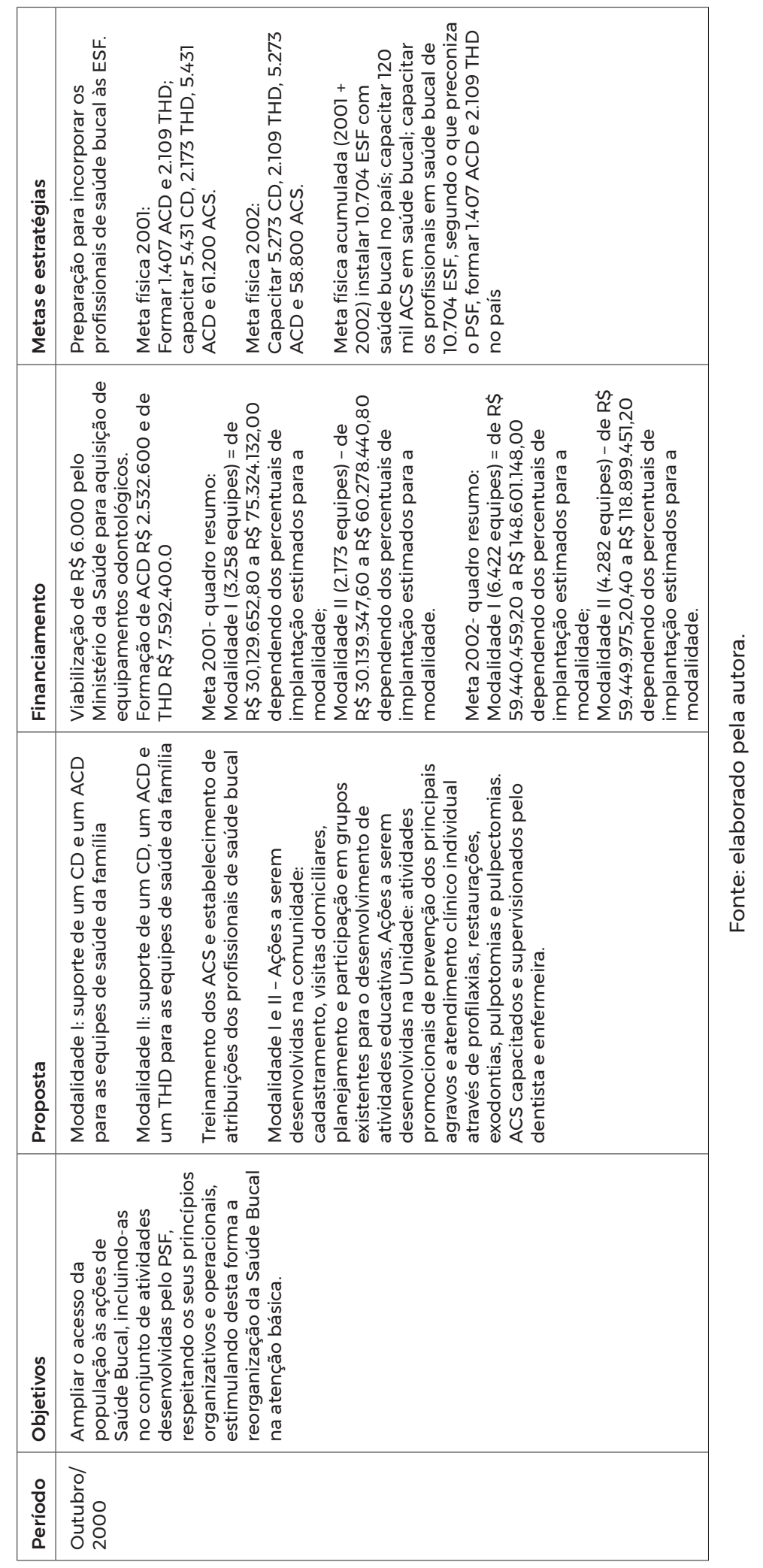

Produção Social da Políticas de Saúde Bucal no Brasil / 163 
Na primeira versão, não havia clareza acerca dos meios operacionais para a capacitação do ACD e do THD. Na segunda e terceira propostas, a etapa relativa ao ACS é incorporada no programa, mas não contando como uma fase. Quanto ao financiamento, nas duas últimas versões, observou-se maior detalhamento dos cálculos sobre procedimentos coletivos e individuais, entretanto, nas três versões, manteve-se o cálculo sobre o salário dos profissionais e valores de referência utilizados pelo Ministério da Saúde. Em nenhuma das três propostas sugere-se a implantação de uma equipe de saúde bucal para duas de saúde da família, conforme chancelado em Portaria oficial. (BRASIL, 2000a, 2000b, 2000d)

A articulação das entidades que mobilizaram parlamentares no sentido de influenciar na decisão de inclusão da saúde bucal no PSF, assim como o papel exercido pelos Enatespo foram de fundamental importância. Os Entrevistados 33 e 34 atribuem ao movimento das entidades o papel decisivo.

Nesse sentido, aponta-se papel importante desempenhado pelas entidades de classe ao interior no campo político, em discordância dos estudos de Garcia (2006) que afirma a ausência de demanda externa ao MS significativa e Rendeiro (2011) que apontara o protagonismo dos burocratas nesse processo. Outro trabalho também aponta que as entidades de classe e os Enatespo atuaram com relevância neste processo (NARVAI, 2011), assim como os achados do presente estudo.

O CTC, formado por dentistas com maior capital científico oriundos das universidades, também foi de fundamental importância no processo. Os gestores da atenção básica apoiavam a entrada da saúde bucal no PSF. A coordenadora da ATSB vinha lutando contra as propostas de até quatro equipes de saúde da família para uma de saúde bucal feitas pela alta administração do Ministério. A gestora buscava apoio e respaldo nas pessoas que compunham seu comitê. O processo de lutas ao interior do Ministério da Saúde foi intenso, com muitas idas e vindas da coordenação de ATSB, com diversos cálculos e tentativas de propostas para a alta administração. O secretário de Políticas de Saúde, Cláudio Duarte da Fonseca, foi o interlocutor no processo de negociação que culminou na aceitação da proposta de uma equipe de saúde bucal (ESB) para duas equipes de saúde da família (ESF).

[...] eu e o secretario discutíamos horas exaustivas e ele não aceitava. Mandava a gente refazer com outro cenário. Nós saímos oito horas da noite, daí íamos sentar refazer as continhas e no outro dia nós íamos [...] nós não queríamos essa questão de dois para um, a nossa proposta era a inclusão do dentista. Então ele começou a aderir assim quatro dentistas para uma equipe, faça as contas. [...] Ele começou faça dois dentistas, faça três dentistas, voltávamos, fazíamos conta. - [...] Quando ele disse quatro dentistas, eu lhe disse: eu não vou fazer. Ele disse: - então é pegar 
ou largar. Eu disse: - dessa vez eu largo. [...] Ele falou vamos fechar em três, eu tenho x e vou fechar em três. Eu disse, então vamos fazer o seguinte, eu vou voltar para sala, vou ligar para o meu comitê e vou conversar com eles. Porque eu também precisava de um respaldo do meu comitê e vou ligar para o CFO, para ABO. Aí foi aquele rebuliço, nem pensar. [...] Voltei no outro dia, às oito horas da manhã do outro dia. [...] Depois desse apelo emocionante, ele levantou, me abraçou e disse: - está bom, me ganhou, duas equipes, pronto. Porque uma ele não aceitava uma [equipe] de jeito nenhum. [...] Então foi assim, liguei para o comitê: - olha duas equipes, modalidade I, modalidade II, agora venham para cá. Mandei passagem para todo mundo, venham para cá, vamos agora sentar, vamos alinhavar, vamos começar isso aqui. ${ }^{89}$

Em uma das reuniões de pactuação das entidades odontológicas e da coordenação da ATSB com o ministro José Serra, ele anunciou ao então presidente do Conselho Federal de Odontologia a proposta de uma ESB x duas ESF, obtendo a aprovação dos presentes.

O Serra é meio duro assim, e eu insistindo né, aí ele olhou pra mim e disse: 'então tá doutor pela sua insistência então dois pra um', eu digo: 'como dois pra um?', 'Duas equipes pra um dentista', ai eu disse: 'tá fechado!', aí estendi a mão e tá fechado. Aí quando eu sai alguns me queimaram: 'você aceitou? Os médicos têm um para um e nós termos dois'. Eu digo: 'bom, tem que começar por algum lugar'. [... $]^{90}$

Assim, em 25 de outubro de 2000, dia no qual se celebra o Dia do Dentista, foi anunciada oficialmente a inclusão da saúde bucal na saúde da família pelo ministro José Serra. As entidades odontológicas e a coordenação de saúde bucal participaram do ato. A foto que estampava a capa do Jornal da FIO não apresentava a descrição dos participantes na celebração, mas cita-se, ao centro, o ministro José Serra, a seu lado direito a dra. Sônia Dantas, a seu lado esquerdo dr. Miguel Nobre, então presidente do CFO, dra. Rozangela Camapum da FIO, dr. Francisco Lubiana, então presidente da $\mathrm{ABO}$. Os membros do CTC não participaram da cerimônia pois não concordavam com a proporção de duas ESF para uma ESB, afirmavam que esta proporção não modificaria o modelo assistencial vigente.

Foram publicadas duas portarias relativas à inclusão da equipe de saúde bucal. A primeira, a Portaria ${ }^{\circ} 1.444$, de 28 de dezembro de 2000, publicada no DOU, de 29 de dezembro de 2000, que estabelecia o incentivo financeiro para a reorga- 
nização da atenção à saúde bucal por meio do PSF. (BRASIL, 2000d) A publicação oficial estabelecia o repasse anual de $\mathrm{R} \$ 13.000$ para equipe da modalidade I (CD + ACD) e R $\$ 16.000$ para a modalidade II (CD + THD + ACD), com repasses mensais fundo a fundo de 1/12 avos. Ademais, fixava o incentivo de $\mathrm{R} \$ 5.000$ para aquisição de equipamentos odontológicos. Cada equipe de saúde bucal deveria atender a 6.900 habitantes e sua implantação deveria obedecer à proporção de duas ESF para uma ESB, sendo que os municípios com menos de 6.900 habitantes poderiam implantar uma ESB para uma ou duas ESF. A segunda portaria, a já mencionada Portaria ${ }^{\circ} 267$, de 6 de março de 2001, publicada no DOU, em 7 de março de 2001, regulamentava o ato anterior. (BRASIL, 2001) Nesta Portaria são traçadas as estratégias para a mudança no modelo de atenção pretendida. Ela se baseou no documento elaborado pelos consultores e definiu as bases para reorientação das ações, a incorporação da equipe de saúde bucal, as atribuições de cada um dos profissionais, inclusive do ACS, as responsabilidades institucionais e o financiamento. (BRASIL, 2001)

O fato foi celebrado por distintos motivos, pelas entidades odontológicas e pela coordenação da ATSB, entretanto, esta sofreu muitas críticas, tanto pela ausência da paridade entre ESB e ESF como pelo próprio atraso na inclusão da saúde bucal no PSF e pela forma como se realizou a inclusão. As críticas foram realizadas por membros do comitê e que participavam dos Enatespo, além das entidades de classe.

Se conseguiu foi um dinheiro novo. Esse mérito tem. Só que com quatro anos de atraso. O que significa esses quatro anos de atraso? Significa que a maioria dos dentistas não participaram do processo de territorialização garantiu o pontapé inicial da criação vinculo usuário-comunidade-equipe. A proporção dois por um é absurda, nenhum dentista dá conta de seis mil, sete mil pessoas, é impossível na atenção primária de qualidade, organizada, com programação adequada, com indicadores epidemiológicos ou sem indicadores mas com um mínimo, mínimo de avaliação epidemiológica [...]. Então esses quatro anos de atraso parece que é pouco na origem do processo mas nos causou problemas. (Entrevistado 7, dentista, consultor)

Outro membro do Comitê, Paulo Capel Narvai, comentou a reação do ministro Serra e também criticou a inclusão tardia da saúde bucal no PSF.

A reação do ministro da Saúde aos dados sobre acesso à assistência odontológica no Brasil causou, entre muitas lideranças odontológicas, impacto 
maior do que os números que a motivaram. Refiro-me, especificamente, ao termo 'abismado' - utilizado por José Serra ao comentar as informações contidas no relatório da PNAD-1998 (Pesquisa Nacional por Amostra de Domicílios), publicado pelo IBGE em agosto de 2000. Não foram poucos os que reclamaram do 'desconhecimento' e da 'ignorância' da principal autoridade pública do setor em relação à desassistência odontológica e ao elitismo do acesso. Sentar na cadeira do dentista continua sendo monopólio de classe social no Brasil. Insuportável privilégio, diga-se - mais uma cruel expressão das iniquidades que nos assolam. [...] Num lampejo, talvez não tenha tido tempo de filtrar seus sentimentos, formulando uma resposta 'politicamente correta' - coisa que, aliás, fez logo em seguida, anunciando a 'inclusão de dentistas nas equipes do programa de saúde da família', uma prioridade da pasta que comanda. Os dados a que me refiro foram amplamente noticiados: dentre os brasileiros, 29,6 milhões (18,7\% da população) nunca foram ao dentista. A porcentagem sobe para $32 \%$ na área rural. (NARVAI, 2000, p. 1)

Manfredini (2006) apontou a ausência de movimentos populares com demandas por serviços odontológicos ou organizações de usuários cariados ou portadores de doenças periodontais ou na luta por próteses dentárias no processo de construção das políticas de saúde bucal. Citou outros trabalhos que defenderam a inserção da SB no PSF como um processo que não refletiu a compreensão das ações de SB na atenção básica, as dificuldades inerentes ao processo de trabalho, a ausência de uma discussão ampla com a participação dos profissionais e não baseada em experiências existentes.

O Jornal do CFO ressaltou, em 2000, ofício enviado ao ministro que enfatizava o grande problema de concentração de profissionais nos grandes centros urbanos e o excessivo número de faculdades de Odontologia no país como fatores para os dados alarmantes da PNAD. (SAÚDE..., 2000) O Jornal da ABO - Seção Rio de Janeiro também festejou a nova opção de mercado de trabalho para o CD. (CALADO, 2002)

A inclusão da equipe de saúde bucal no PSF representou uma grande alternativa de mercado de trabalho para o cirurgião-dentista. $O$ alto número de profissionais recém-formados que adentra o mercado de trabalho, anualmente, a redução do índice de cárie da população brasileira, principalmente infantil, assim como a crise do modelo assistencial privatista na Odontologia como única fonte de recursos representavam pontos críticos para a atuação profissional no período. (CALADO, 2002) 
No ano de 2001, a CNSB voltou a receber críticas do CRO-SP em sua nota sobre o dia do dentista, em 25 de outubro de 2001. Reforçando a questão sobre o mercado de trabalho, o Conselho Regional apontava a ausência de uma política séria para o setor, o que acarretava dificuldades ao exercício profissional e à população assistida.

A FIO abordou o fato como uma conquista histórica da Odontologia para a categoria e para a população, de uma luta que durou seis anos, além de enfatizar todo o trabalho “de pressão" exercido pela entidade. Noticiou, também, a inclusão do pessoal auxiliar na ESB e a formação a ser realizada.

Já para a coordenação da ATSB, representava a expressão de uma luta das entidades de classe, dos movimentos de crítica organizados, como os Enatespo, além de uma política que beneficiaria a população com o aumento do acesso a serviços odontológicos e a redução da cárie dentária, pautas também oriundas das discussões com o CTC.

Destaca-se que, no período de 1996 a 2001, a mídia voltou a retratar a ausência de uma política nacional de saúde bucal, em matérias das entidades de classe. Na segunda metade da década de 1990, também ocorreram os Congressos de Saúde Bucal Coletiva em articulação com os Enatespo, o que proporcionou integração de mais agentes do campo científico aos eventos, que tinham como principal objetivo ser um espaço de crítica às políticas de saúde bucal. Quanto ao campo político, além da atuação junto ao ministro pela inclusão da Saúde Bucal no PSF, cita-se o PL n 3504/2000 submetido pelo deputado Rubens Bueno, do PPS do Paraná, que buscava determinar a obrigatoriedade dos hospitais de grande porte contarem com cirurgiões-dentistas em seus corpos clínicos. Entretanto, não há documentos que formalizem a articulação da saúde bucal nos distintos níveis de atenção. Outra iniciativa no campo político foi a indicação do deputado Marcos Cintra, do PFL de São Paulo, para a mudança das denominações constantes na Classificação Brasileira de Ocupações (CBO), de auxiliar de Consultório Dentário e de técnico em Higiene Dental para, respectivamente, atendente de Saúde Bucal e técnico em Saúde Bucal (Quadro 15).

Quanto ao planejamento orçamentário no período de 1995 a 2002, observa-se que, nos primeiros cinco anos, houve uma drástica redução, tendo representado menos que $1 \%$ do orçamento do Ministério da Saúde, fato que expressa a ausência de priorização do setor dentro do MS (Tabela 4). 


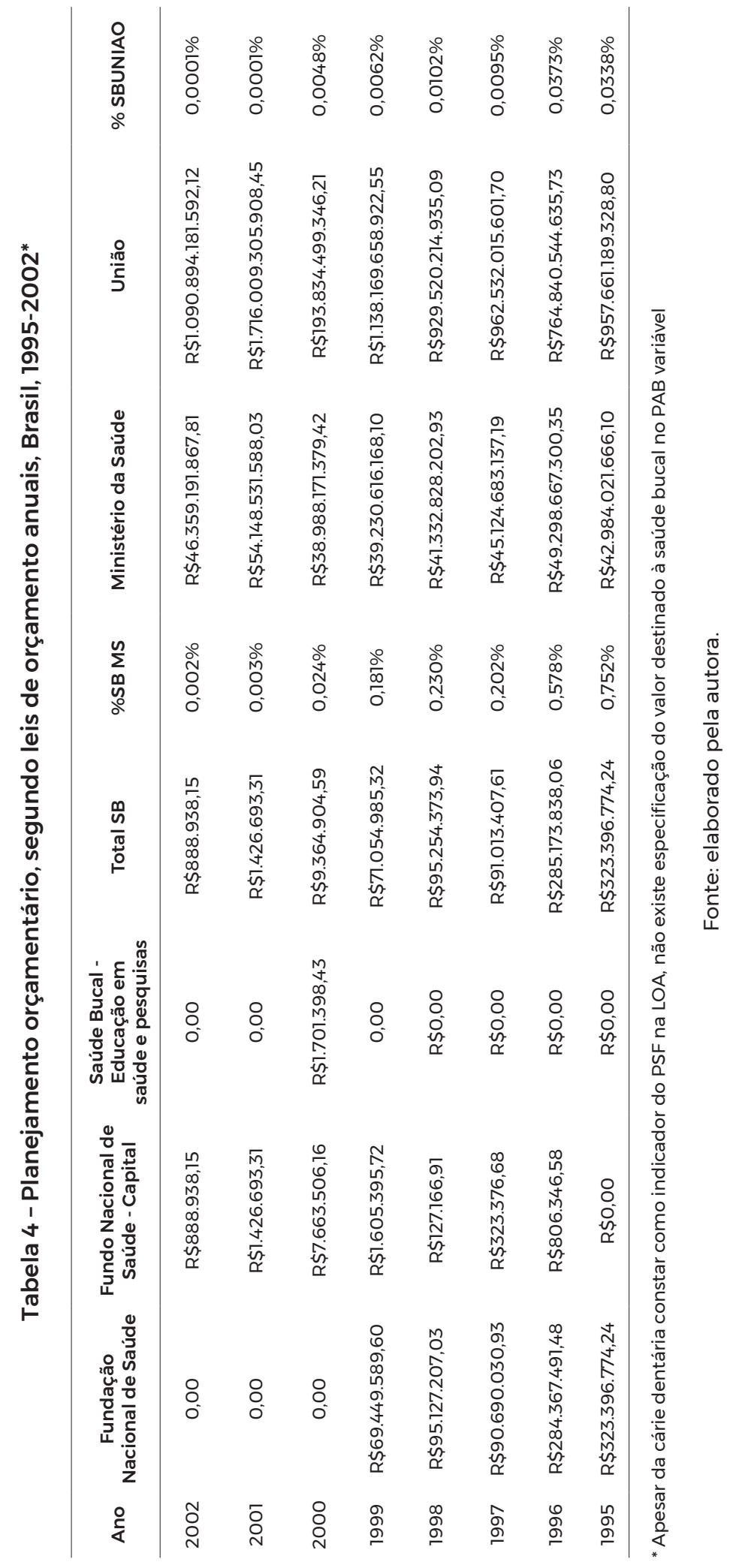

Produção Social da Políticas de Saúde Bucal no Brasil / 169 


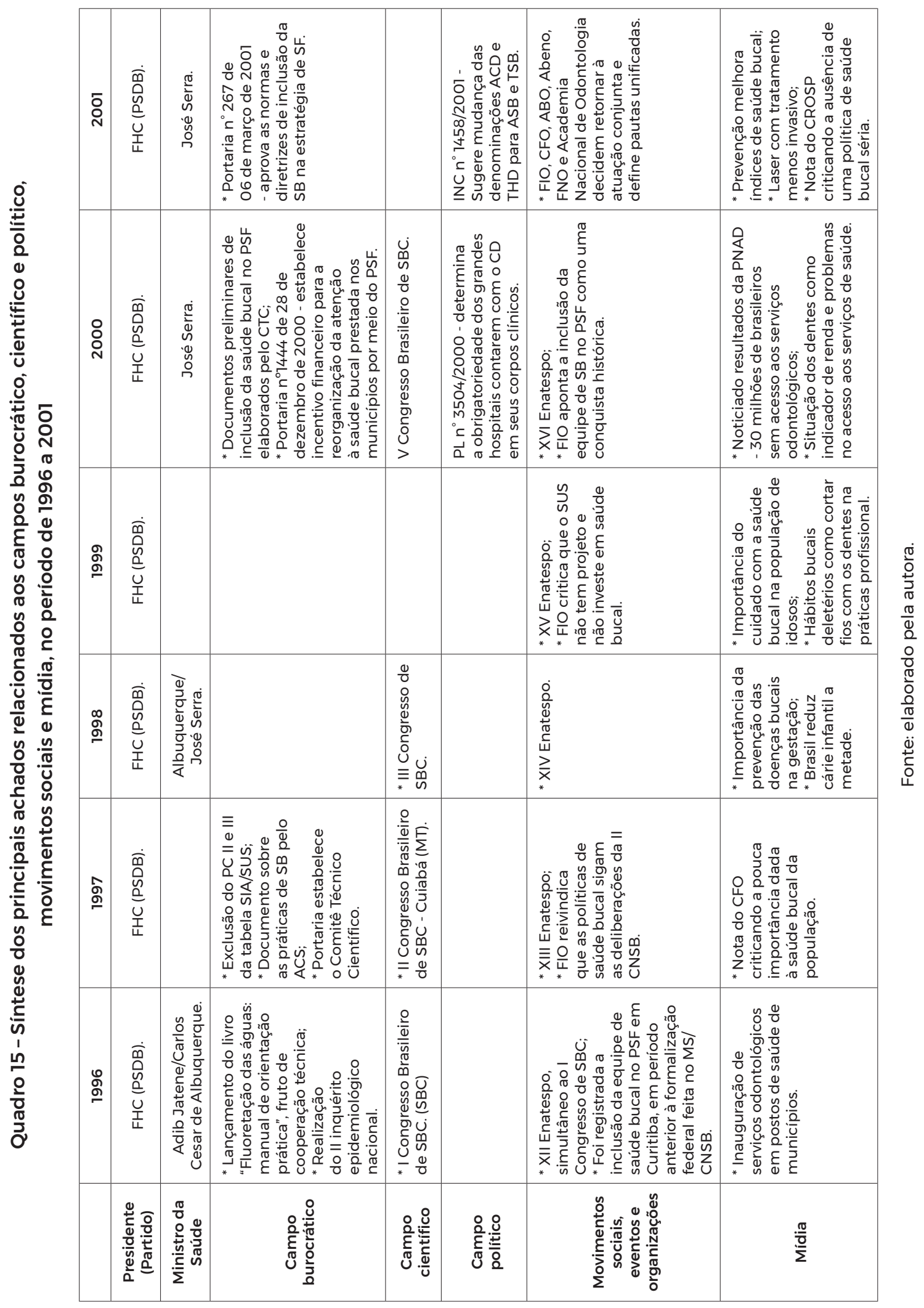




\section{Participantes e disposições que influenciaram a inclusão da equipe de saúde bucal no Programa de Saúde da Família}

Os principais participantes na inclusão da equipe de saúde bucal na agenda foram cirurgiões-dentistas, com exceção do Secretário de Políticas de Saúde, Cláudio Duarte da Fonseca, ${ }^{91}$ que foi um grande interlocutor entre a Área Técnica de Saúde Bucal e a alta administração do Ministério da Saúde. A maioria era do sexo masculino, mas, a partir desta política, observou-se maior inserção das mulheres no espaço de formulação das políticas de saúde bucal, a começar pela própria gestora e também pela presidente da FIO que representou grande apoio na inserção da pauta na agenda do Estado, além das mulheres que eram gestoras de saúde bucal no nível estadual e que também participaram das discussões (Quadro 16).

Alguns membros que participavam dos Enatespo, subespaço contrahegemônico de crítica às políticas nacionais de saúde bucal, também integravam o CTC de assessoramento da coordenadora, como Paulo Capel Narvai e Djalmo Sanzi Souza. A própria gestora participou de alguns eventos e afirmava buscar seguir as recomendações do Enatespo.

Outra instituição fundada para exercer papel semelhante foi a Associação Brasileira de Saúde Bucal Coletiva (Abrasbuco), criada em 1998, em reunião do Enatespo, mas, apesar de alguns membros terem integrado esta Associação, não a reconhecem como partícipe no espaço nacional de formulação das políticas.

As entidades de classe exerceram papel importante na mobilização junto ao campo político, atuando frente a parlamentares e ao ministro da Saúde. A gestora nacional do setor atuou no processo de pactuação no interior do campo burocrático. O CTC desempenhou um papel fundamental na concepção teórica, na articulação com os pressupostos da Atenção Primária à Saúde e na formulação inicial da política. Foram realizadas mudanças entre a proposta inicial do CTC, principalmente relativa à relação ESB $x$ ESF, e aquela aprovada ao final do processo, entretanto, há muitas semelhanças entre a Portaria $n^{\circ} 267$, de março de 2001, e o documento preliminar de outubro de 2000, com os objetivos, atribuições profissionais, responsabilidades institucionais.

A FIO também auxiliava o CFO e outras entidades no direcionamento político, por ter membros com alto capital político com inserção neste campo. Alianças com outras entidades, como a Associação Brasileira de Odontologia, Academia Brasileira

91 Conforme consta em seu currículo lattes, Cláudio Duarte da Fonseca é graduado em Medicina pela Universidade Federal de Pernambuco (UFPE) (1987), mestre em Saúde Coletiva pelo Instituto de Saúde Coletiva da Bahia (2002); especialista em Medicina Preventiva e Social pela UFPE/HC/Inamps (1987); médico sanitarista da Secretaria Estadual de Saúde de Pernambuco. Nos últimos 14 anos, vem participando, em âmbitos municipal, estadual e federal, de projetos de reestruturação de sistemas de atenção à saúde e programas de saúde pública. 
de Odontologia, Federação Nacional dos Odontologistas, Conselhos Regionais de Odontologia, foram realizadas para aumentar a base de apoio para a inclusão da SB no PSF frente ao governo.

A aprovação da inclusão da Odontologia no PSF foi fruto da articulação de membros oriundos do movimento sanitário e contrahegemônicos da Odontologia com as entidades representativas de classe que contaram com uma coordenadora com trajetória no interior do campo burocrático na Área Técnica de Saúde Bucal.

Dentre aqueles que participavam ativamente dos Enatespo, observa-se acumulação média de capital político assim como do burocrático. Quanto ao capital científico, observou-se maior acumulação nos membros do CTC. O presidente do CFO e a presidente da FIO apresentaram acumulação semelhantes dos capitais com atuação no campo político (Figuras 16, 17 e 18).

Dentre aqueles que participavam dos Enatespo, alguns exerciam cargos na gestão estadual, outros na gestão municipal, outro em cargo político ou atuavam no campo burocrático como consultores. Alguns eram professores universitários, tendo exercido cargos na gestão. Observou-se, ainda, que a maioria apresentava capital científico muito baixo, no período, com exceção de dois dentistas, que eram professores e pesquisadores, membros do comitê e de outro agente que participou da discussão da política.

Conforme já referido, o papel exercido pela coordenação da Área Técnica de Saúde Bucal apoiou-se no comitê composto por agentes com inserção no campo científico, assim como o político, através das alianças estabelecidas.

Quanto às tomadas de posição, os membros do CTC defendiam que a inclusão da equipe de saúde bucal modificaria o modelo de atenção praticado, perpassando o processo de trabalho na saúde bucal. Incluíam na agenda a pauta do pessoal auxiliar, oficializando a inclusão da "equipe de SB" e não apenas do dentista no PSF.

Essa discussão, conforme já referido, vinha sendo defendida em reuniões do MBRO, nos Enatespo, assim como na primeira política de saúde bucal de 1989. Além de exercer ações individuais no consultório, os membros da equipe de saúde bucal deveriam desenvolver ações coletivas na comunidade em articulação com os outros profissionais e respeitando as necessidades do território. Ademais, não seguiriam uma lógica de remuneração por procedimento, como nos procedimentos coletivos da década de 1990. A presidente da FIO e seus membros defendiam que a Odontologia era uma especialidade da medicina e que toda a população deveria ter acesso ao atendimento integral. O CFO também mencionou a Odontologia como especialidade médica, mas defendeu, principalmente, a tomada de posição da expansão do mercado de trabalho para o dentista, assim como outras entidades odontológicas como a $\mathrm{ABO}$ e a FNO. 


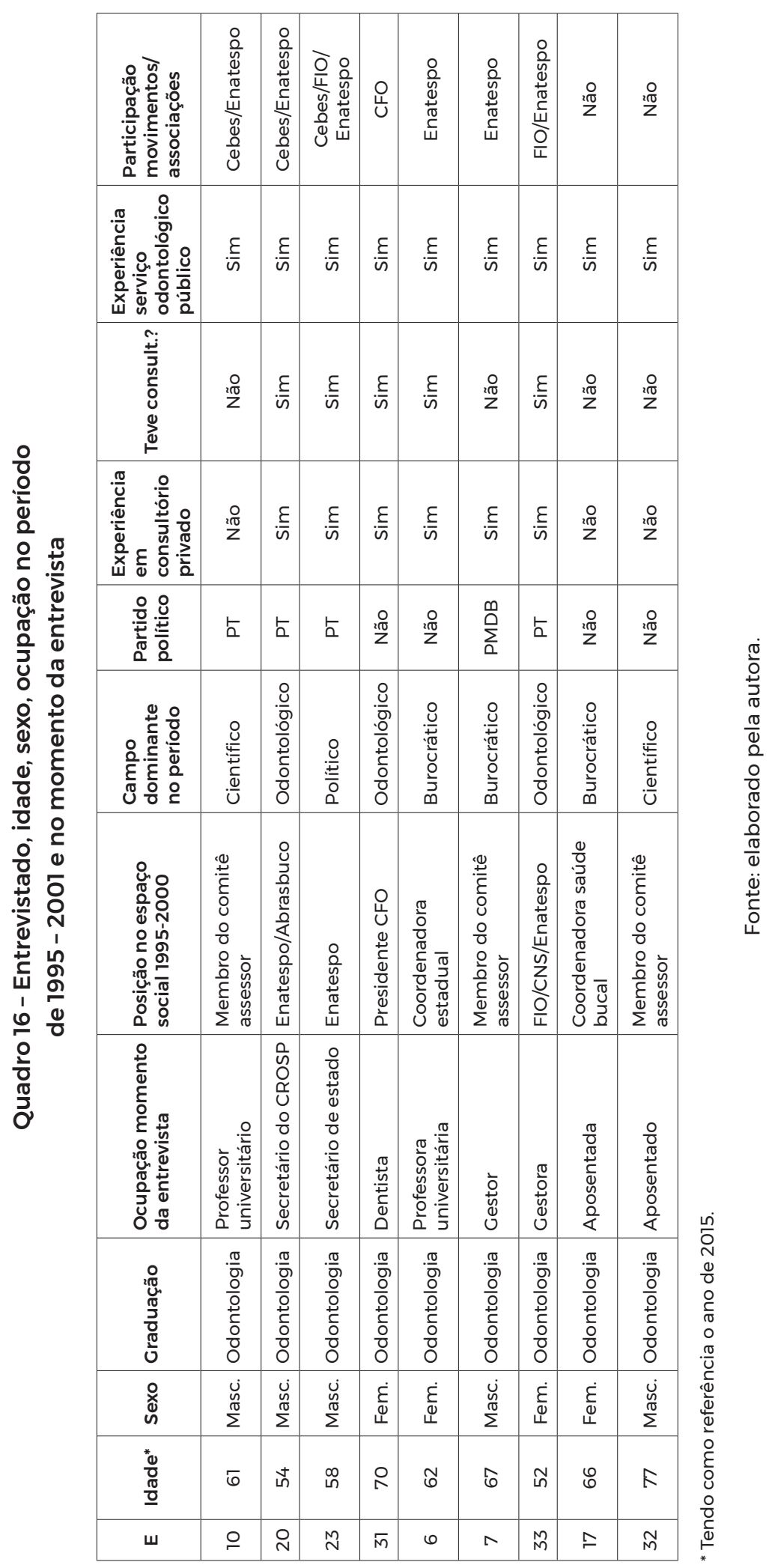


Assim, a inclusão do CD no PSF representava o aumento de postos de traba1ho, muito concentrado em grandes centros urbanos em detrimento do desenho de modelo de atenção concebido por membros do CTC e defendido pelos participantes do Enatespo no qual a mudança realizada assegurava mudanças quanto ao processo de trabalho dos profissionais.

A maioria dos dentistas que participaram da inclusão da equipe de saúde bucal no PSF se identificou como cirurgiões-dentistas em instâncias que exigem apresentação de si ao mundo social como, ao hospedar-se em um hotel, mesmo os bucaleiros, o que pode revelar a preservação da identidade profissional de origem no caso daqueles cuja principal ocupação atual é na Saúde Coletiva.

Havia uma dominância de agentes com maior capital burocrático e político do que científico. O maior volume global de capital estava relacionado aos membros do CTC que participavam dos Enatespo e um membro da FIO (Quadro 17). A coordenação nacional de SB apresentou acumulação global semelhante aos agentes das entidades de classe, mas com composição distinta. O capital predominante na coordenação, era o burocrático, e nas entidades de classe, o político. Os membros do CTC ligados ao Enatespo e os membros da FIO apresentavam trajetória ascendente, concepção de SUS democrático e participaram de movimentos estudantis. Já o presidente do CFO apresentava concepção do SUS distinta, com trajetória ascendente, exercício liberal da profissão e não participou de movimentos estudantis. (Quadro 18)

\section{Quadro 17 - Entrevistado, segundo distribuição e volume dos capitais científico, político e burocrático}

\begin{tabular}{|c|c|c|c|c|c|c|c|c|c|c|c|c|c|}
\hline \multirow[b]{2}{*}{$E$} & \multicolumn{4}{|c|}{ Capital Científico } & \multicolumn{4}{|c|}{ Capital Político } & \multicolumn{4}{|c|}{ Capital Burocrático } & \multirow{2}{*}{$\begin{array}{l}\text { Volume } \\
\text { total }\end{array}$} \\
\hline & $\uparrow$ & $\uparrow \uparrow$ & $\uparrow \uparrow \uparrow$ & $\uparrow \uparrow \uparrow \uparrow$ & $\uparrow$ & $\uparrow \uparrow$ & $\uparrow \uparrow \uparrow$ & $\uparrow \uparrow \uparrow \uparrow$ & $\uparrow$ & $\uparrow \uparrow$ & $\uparrow \uparrow \uparrow$ & $\uparrow \uparrow \uparrow \uparrow$ & \\
\hline 10 & & & & & & & & & & & & & 7 \\
\hline 23 & & & & & & & & & & & & & 6 \\
\hline 20 & & & & & & & & & & & & & 4 \\
\hline 32 & & & & & & & & & & & & & 2 \\
\hline 6 & & & & & & & & & & & & & 3 \\
\hline 31 & & & & & & & & & & & & & 3 \\
\hline 33 & & & & & & & & & & & & & 3 \\
\hline 17 & & & & & & & & & & & & & 3 \\
\hline 7 & & & & & & & & & & & & & 3 \\
\hline
\end{tabular}

Fonte: elaborado pela autora. 
Figura 16 - Agentes participantes do espaço de formulação de crítica das políticas de saúde bucal, segundo capitais burocrático e científico, 1998-2001

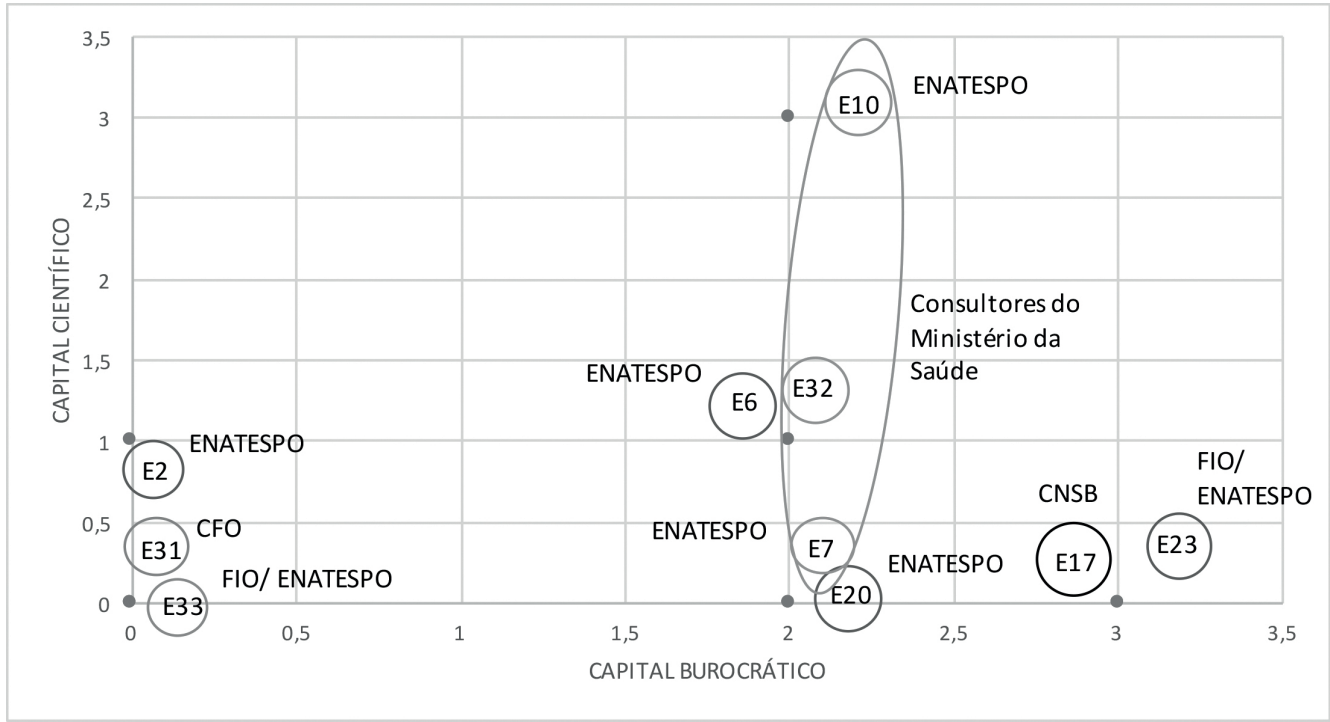

Fonte: elaborado pela autora.

Figura 17 - Agentes participantes do espaço de formulação de crítica das políticas de saúde bucal, segundo capitais burocrático e político 1998-2001

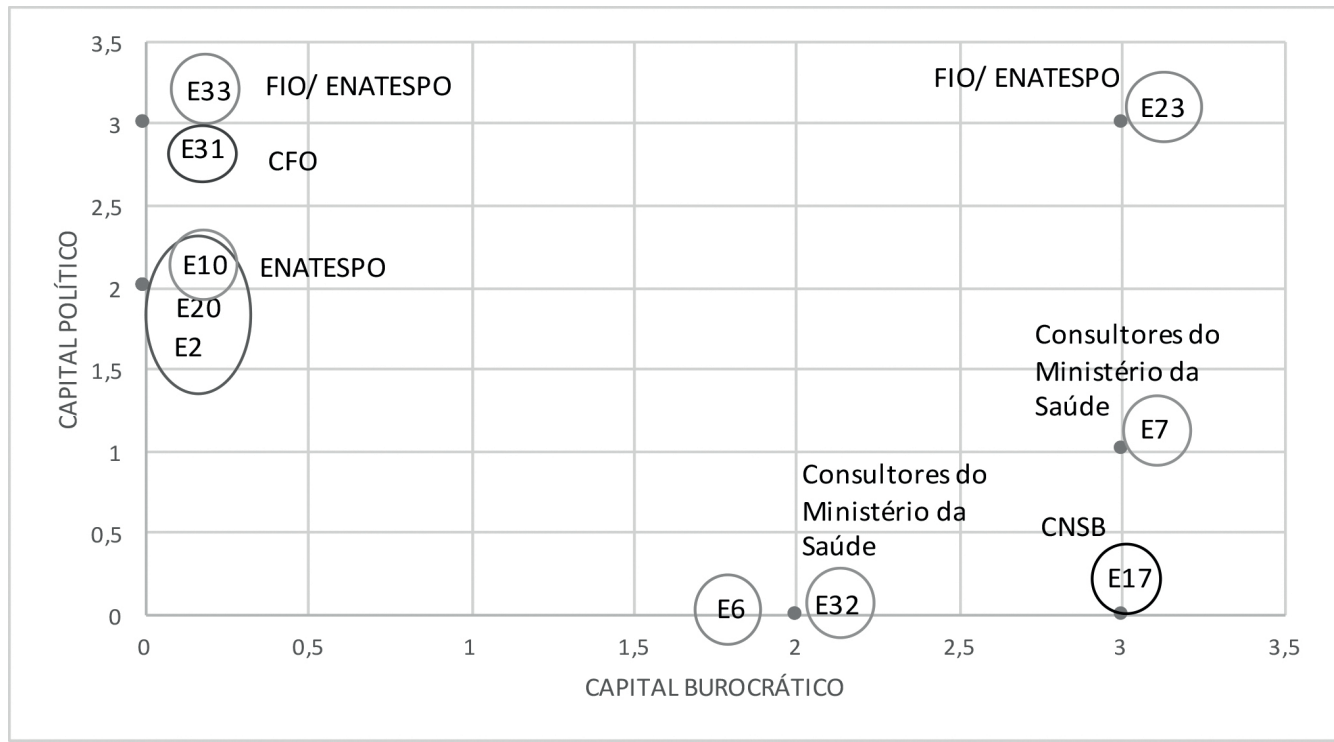

Fonte: elaborado pela autora. 
Figura 18 - Agentes participantes do espaço de formulação de crítica das políticas de saúde bucal, segundo capitais científico e político, 1998-2001

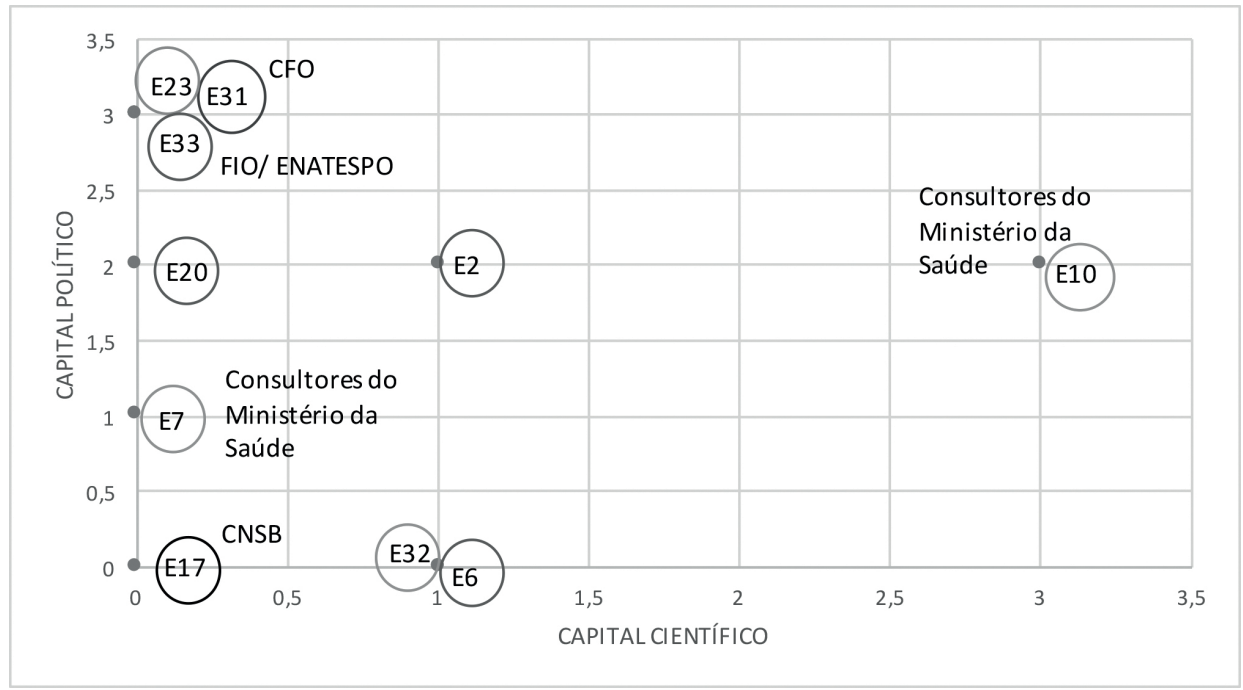

Fonte: elaborado pela autora.

De maneira distinta ao ocorrido no início da década de 1990, os termos mais citados com cinco letras foram "saúde" e "bucal". A Odontologia e dentista estão também nos primeiros planos mostrando o enfoque na profissão. Surgem, em um segundo plano, palavras referentes ao nível político onde as políticas foram articuladas como presidente, governo, político, ministro, ministério. No caso da política de inclusão da Saúde Bucal no PSF, o papel do ministro José Serra foi relevante, com papel importante, e também pelo cenário político nacional representado pelo governo FHC com restrições a um projeto de governo que contemplasse a saúde bucal da população em todas as suas necessidades (Figura 19).

As palavras "movimento", "Abrasbuco”, "conselho", "lideranças”, "conferências”, "entidades”, “coletiva” também surgem como palavras mais referidas pelos entrevistados, o que corresponde à existência dos movimentos, de mobilizações e de pactuações realizados pelas entidades de classe e coordenação de saúde bucal. A Abrasbuco, apesar de ter sido muito referida como uma associação fundada para crítica, não foi considerada partícipe do espaço de formulação dessa política de saúde bucal. 


\begin{tabular}{|c|c|c|c|c|c|c|c|c|c|c|}
\hline \multirow{10}{*}{ 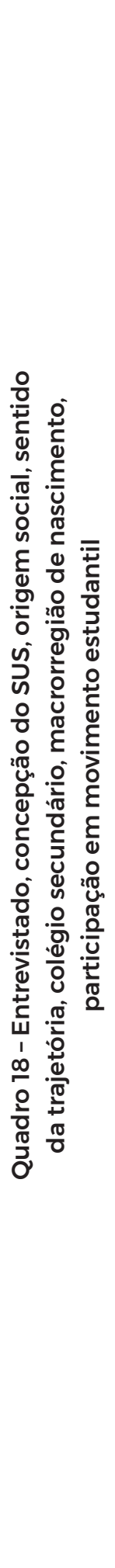 } & 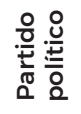 & $\underset{2 \pi}{2 \pi}$ & $\frac{\varepsilon}{n}$ & $\frac{\varepsilon}{i n}$ & $\frac{i \pi}{2}$ & $\frac{\xi}{n}$ & E & $\underline{\xi}$ & $\frac{2}{2 \pi}$ & $\frac{\xi}{n}$ \\
\hline & 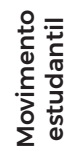 & $\frac{\varepsilon}{n}$ & $\frac{\varepsilon}{\omega n}$ & $\frac{E}{i n}$ & $\frac{0}{2 \pi}$ & $\frac{\varepsilon}{i n}$ & $\stackrel{2}{2 \pi}$ & $\frac{20}{2 \pi}$ & $\frac{E}{i n}$ & $\frac{\varepsilon}{n}$ \\
\hline & $\begin{array}{l}\frac{0}{200} \\
\frac{20}{0} \\
\propto\end{array}$ & $\overline{\bar{n}}$ & $\overline{\breve{s}}$ & $\overline{\bar{n}}$ & $\begin{array}{l}\stackrel{0}{ \pm} \\
\frac{0}{2}\end{array}$ & 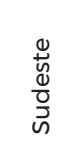 & $\begin{array}{l}\frac{\mathrm{g}}{\Delta} \\
\frac{0}{0} \\
\frac{0}{0} \\
z\end{array}$ & $\overline{\bar{S}}$ & $\overline{\bar{s}}$ & 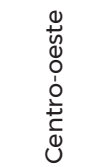 \\
\hline & 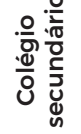 & $\frac{.0}{\frac{.0}{0}}$ & 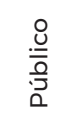 & $\frac{\stackrel{8}{-0}}{\frac{0}{0}}$ & $\frac{.0}{\frac{0}{0}}$ & 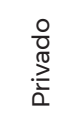 & $\begin{array}{l}\stackrel{8}{0} \\
\frac{0}{0} \bar{a} \\
\square\end{array}$ & $\begin{array}{l}\frac{0}{0} \\
\stackrel{\pi}{\pi} \\
\stackrel{2}{2} \\
0\end{array}$ & $\begin{array}{l}\frac{8}{3} \\
\frac{0}{3} \\
\frac{0}{2}\end{array}$ & $\begin{array}{l}\frac{0}{0} \\
\stackrel{0}{\pi} \\
? \\
\frac{1}{2}\end{array}$ \\
\hline & 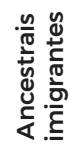 & $\frac{\xi}{n}$ & $\frac{E}{\omega}$ & $\frac{\xi}{n}$ & $\frac{2 \pi}{2}$ & $\frac{20}{2}$ & $\frac{\substack{20 \\
z}}{2}$ & $\frac{\xi}{n}$ & E & $\frac{20}{2 \pi}$ \\
\hline & 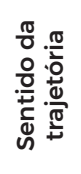 & 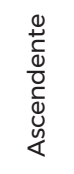 & 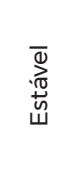 & 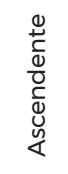 & 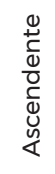 & 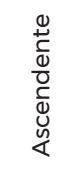 & 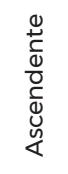 & 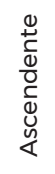 & 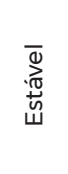 & 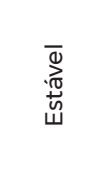 \\
\hline & 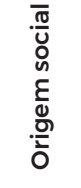 & $\begin{array}{l}\frac{\bar{\sigma}}{\frac{1}{3}} \\
\frac{0}{0} \\
\frac{0}{0}\end{array}$ & $\begin{array}{l}\frac{\pi}{\overline{0}} \\
\frac{\pi}{2}\end{array}$ & $\begin{array}{l}\frac{\bar{\sigma}}{\bar{\sigma}} \\
\frac{0}{0} \\
\square\end{array}$ & $\begin{array}{l}\frac{\bar{d}}{3} \\
\frac{0}{0} \\
\frac{0}{0}\end{array}$ & $\begin{array}{l}\frac{\bar{\sigma}}{\overline{3}} \\
\frac{0}{0} \\
0\end{array}$ & $\begin{array}{l}\frac{\pi}{\overline{0}} \\
\sum \\
\Sigma\end{array}$ & $\begin{array}{l}\frac{\bar{\pi}}{5} \\
\frac{0}{0} \\
\frac{0}{0}\end{array}$ & $\begin{array}{l}\frac{\pi}{\overline{0}} \\
\frac{\pi}{2}\end{array}$ & $\begin{array}{l}\frac{\pi}{\overline{0}} \\
\frac{\pi}{2}\end{array}$ \\
\hline & 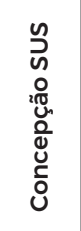 & 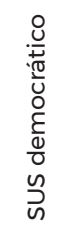 & 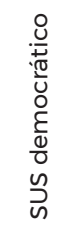 & 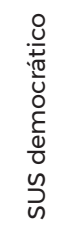 & 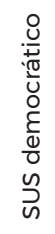 & 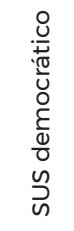 & 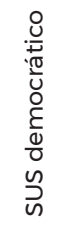 & 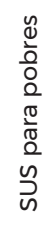 & 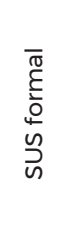 & 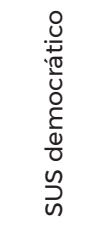 \\
\hline & 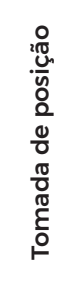 & 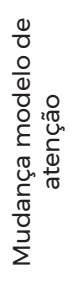 & 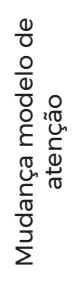 & 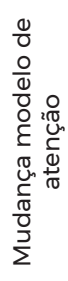 & 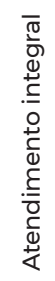 & 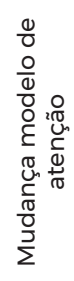 & 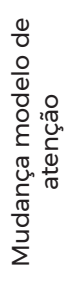 & $\begin{array}{l}\overline{0} \\
\frac{0}{0} \\
\overline{0} \\
\frac{0}{0} \\
0 \\
\frac{0}{0} \\
0 \\
\frac{0}{0} \\
\frac{0}{0} \\
\frac{0}{2}\end{array}$ & 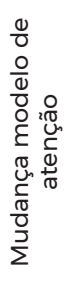 & 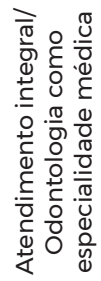 \\
\hline & ш & 6 & n & $\stackrel{\circ}{\circ}$ & 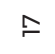 & $\stackrel{\circ}{N}$ & $\stackrel{M}{N}$ & $\bar{m}$ & N & $\stackrel{M}{M}$ \\
\hline
\end{tabular}


Figura 19 - Palavras mais frequentes a partir de cinco, seis, sete, nove, dez e onze letras
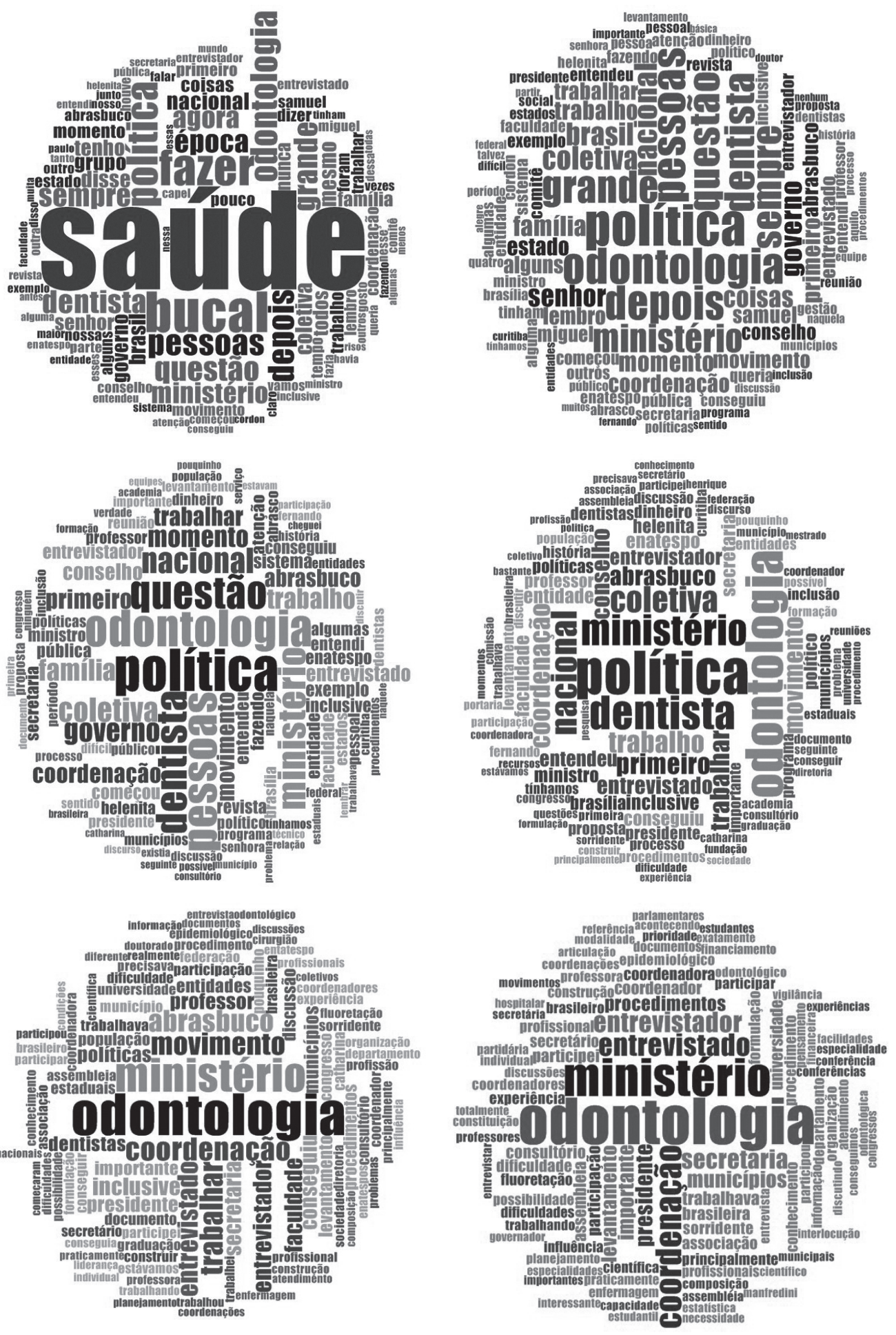

Fonte: elaborado pela autora. 


\section{POLÍTICA BRASIL SORRIDENTE}

Um novo documento intitulado "Política Nacional de Saúde Bucal no Brasil PNSB” publicado em 2004, formalizou as políticas de atenção à saúde bucal no Brasil a partir desta data - a política "Brasil Sorridente".

Alguns autores como Andrade (2008) e Narvai (2011), consideram que o início da formulação da PNSB, de 2004, partiu de movimentos desencadeados desde as décadas de 1970 e 1980). Narvai (2011), participante da comissão de assessoramento, recupera uma longa gênese deste processo iniciada na luta contra a ditadura militar e com ganho de expressão técnico-política nos ECEO, Enatespo, congressos de Odontologia e Saúde Coletiva, conferências de saúde e entidades como a FIO, a Aboprev, Reforma Sanitária Brasileira, o MBRO e da Saúde Bucal Coletiva.

O autor e participante do processo de formulação da política afirmou que foi um processo de "longa maturação" que foi se definindo em um processo coletivo de construção vinculado à Reforma Sanitária e "[...] às trajetórias históricas das forças partidárias que se articularam na coligação que, em 2002, levaria à eleição de Lula”. (NARVAI, 2011, p. 24) Apontou, ainda, que a maior decisão estratégica do governo Lula foi ter assumido as proposições recusadas em seu conjunto nos governos democráticos anteriores. (NARVAI, 2011) Conforme já mencionado, uma série de propostas para as políticas de saúde bucal foram retratadas ao longo dos Enatespo e muitas delas não foram reconhecidas como respostas aos problemas bucais pelo Estado. Contudo, cumpre questionar quais as diferenças e semelhanças da política Brasil Sorridente das outras políticas nacionais editadas no Brasil? Como se deu o processo de formulação do documento?

No processo de candidatura presidencial, já existiam pleitos para um programa de saúde bucal "mais efetivo" para a população de baixa renda pelo CFO. ${ }^{92}$

Miguel Nobre em entrevista à autora, Porto Alegre, 2014. 
Apesar de não constarem ações voltadas para a saúde bucal no projeto de governo de 2002, a setorial nacional de saúde do PT, a partir de reuniões regionais, vinha discutindo ações para a saúde bucal segundo relato dos entrevistados.

Após a eleição do presidente Luiz Inácio Lula da Silva, reuniram-se em São Paulo (SP), militantes do PT, Partido Comunista do Brasil (PC do B) e Partido Socialista Brasileiro (PSB), no dia 24 de novembro de 2002, a fim de elaborar uma proposta para a saúde bucal direcionado à equipe de transição do governo Lula. (FOME..., 2002)

Político. Político-partidário. É isso que eu estou me referindo, são pessoas que eram militantes dos partidos aliados que na época faziam parte da coligação do presidente Lula, que era PT, PCdoB, PCB. Hegemonicamente petista, né? Mas tinha gente de outros partidos também, mas o recorte era recorte político. Um recorte que já vinha lá desde o Mbro, que é um recorte fundamentalmente político, de contra hegemônico, de pessoas da Odontologia vinculados a área pública com proposta contra hegemônicas, desse grupo de construtores da saúde bucal coletiva todos tinham vinculação partidária, no mínimo política, então é sempre esse grupo que vinha formulando e que logo depois da eleição se reuniu em São Paulo, fizemos o seminário, desse seminário saíram esses nomes e esses nomes foram encaminhados. (Entrevistado 19, professor universitário, gestor)

Muitos desses dentistas também haviam participado do Movimento Sanitário, MBRO e Enatespo e tinham vinculação partidária ou faziam parte de cargos em governos petistas. Aqueles que não participaram dos espaços citados, não tinham filiação partidária ou não participavam de governos do PT enquanto gestores não compuseram o grupo. Este grupo contava com dentistas do campo científico, burocrático e político.

Vou dizer que foi a academia junto com o pessoal de São Paulo, mas um monte de gente assim, de pessoas que estavam já em estados que tinham politicas pública de saúde bucal [...] gente estava construindo assim num grupo maior essa questão de discutir como vai ser uma política nacional, como seria uma política nacional. (Entrevistada 20, professora universitária)

A reunião, que foi convocada pela setorial de saúde do $\mathrm{PT}$, contou com a presença de, aproximadamente, 100 pessoas (GARCIA, 2006) e foram discutidas as linhas gerais de natureza política da Política Brasil Sorridente. (NARVAI, 2011) Foi construído um diagnóstico da situação da saúde bucal bem como identificadas as ações a serem desenvolvidas nos 100 primeiros dias de governo, desenhou-se, 
preliminarmente, o trabalho para a saúde bucal no governo federal, ademais, analisou-se aspectos do perfil do ministro da saúde e do futuro coordenador de saúde bucal do governo Lula. (FOME..., 2002)

O documento é iniciado com uma referência ao Programa Fome Zero do projeto de governo do recém-eleito presidente da república e a relação da saúde bucal com prioridade para as políticas públicas. (FOME..., 2002)

Preliminarmente, consideramos necessário assinalar que o anúncio do Programa Fome Zero como a primeira manifestação do Presidente Eleito ao povo brasileiro sinaliza, clara e inequivocamente, um conjunto de prioridades para as politicas públicas que, em nosso entendimento, inclui a saúde e, nela, a saúde bucal, uma vez que tornar fome zero uma realidade para todos os brasileiros implica assegurar-lhes condições para mastigar bem. E ter dentes é condição para mastigar bem. Manter dentes saudáveis e, na sua falta, prover dentes aos que deles necessitam constitui, sem dúvida, enorme desafio no conjunto de desafios do Programa Fome Zero. Daí nossa consigna: Fome zero, boca cheia de dentes! (FOME..., 2002, p. 1)

Ao associar o projeto de governo da nova presidência "Programa Fome Zero" à condição de ter dentes para mastigar bem, Bartole (2006) afirma que foi aberta uma janela de oportunidades por esta equipe de militantes após o cálculo estratégico para sustentação política da proposta. Garcia (2006) reforça o argumento explicando que o termo janela de oportunidade foi utilizado para expressar a busca pela garantia de entrada e priorização na agenda, hipótese refutada por Narvai (2011) quando afirma que o processo de construção da política é fruto de uma longa construção histórica iniciada no movimento de democratização do país.

Pires (2004) afirma que o nome da proposta política induz a uma falácia de viabilidade de que se as pessoas tiverem dentes sadios, se terá um país sorridente. O autor argumenta que o equívoco pedagógico induz a que o nome da política tome a estrutura física, o dente, como objeto da saúde bucal e não o homem em sua integralidade.

No documento, foram reconhecidas as dificuldades no cenário socioeconômico e político e sustentada a desaprovação de que o ministro da saúde fosse algum ex-ministro do governo Collor. Havia críticas quanto à perda de capacidade de interlocução, interna e externa ao Ministério, da coordenação de saúde bucal, à incapacidade de realização do inquérito epidemiológico SB Brasil - 2000 e apontava-se que a última Conferência Nacional de Saúde Bucal havia ocorrido em 1993.

Foram definidos 23 objetivos de balizamento das ações de saúde bucal no governo Lula enquanto esboço inicial da PNSB, dentre os quais destacam-se: 
- estabelecer com clareza que a saúde bucal no âmbito federal requer uma política e um responsável pelo acompanhamento, controle e avaliação desta política, sendo isso muito mais abrangente do que "aprisionar" a saúde bucal em um órgão da estrutura administrativo-burocrática do MS. Tal política e seu respectivo responsável devem, para cumprir suas funções, estar integrados e articular ações em todos os níveis e instâncias da gestão da saúde, em nível federal, articulando tais ações com as deliberações do Conselho Nacional de Saúde, da Plenária Nacional de Saúde e da Plenária Nacional de Conselheiros;

- construir uma Política Nacional de Saúde Bucal para o governo Lula, com ampla participação da população, dos estados, dos municípios, dos trabalhadores e suas entidades representativas e das entidades odontológicas;

- articular a Política Nacional de Saúde Bucal às políticas de saúde e às demais políticas públicas, de acordo com os princípios e diretrizes do SUS;

- convocar, imediatamente, a III CNSB, a ser realizada em 2003, precedida de conferências municipais e estaduais;

- apoiar a organização do Enatespo e dos Encontros Estaduais de Serviços Públicos Odontológicos, como elemento estratégico da ação do MS, e aprofundar vínculos e relações com estados e municípios, nos termos das relações mantidas pelo nível federal com essas esferas de governo. (FOME..., 2002)

[...] primeiro se formulou o seguinte, se discutia a criação, aí sim, de uma política nacional de saúde bucal que fosse coerente com os princípios do SUS, que surgiu depois naquele documento Fome Zero e Boca Cheia de Dentes. Aquele documento sintetiza justamente o que a gente trabalhou daquela reunião de São Paulo pra se assumir o governo[...] foi discutido pela primeira vez uma coisa mais focada na saúde bucal. (Entrevistado 19, professor universitário, gestor)

Cumpre destacar as políticas preexistentes com a formalização através de documentos e portarias, conforme já ressaltado no presente estudo. Os dois objetivos prioritários para os primeiros 100 dias de governo foram: (i) convocar, definir uma agenda e divulgar, amplamente, a III CNSB; e (ii) apoiar política e administrativamente a finalização do Levantamento Epidemiológico SB-2000, de modo a agilizar processos e, tão rápido quanto possível ao novo governo, anunciar os resultados da pesquisa. (FOME..., 2002) 
Observou-se tomadas de posições distintas entre o papel da academia e da política quanto à ação. Assim, os entrevistados defenderam que existiam membros do campo científico, mas que também eram militantes políticos.

Isso aí desse documento é o documento Fome Zero e Boca Cheia de Dentes, isso é uma palavra de ordem [...] que vai dar o tom da política. (Entrevistado 19, professor universitário, gestor)

[O documento] é a operacionalização, a escrita de como se operacionaliza aquela intenção, aquela intenção é manual das Conferências, ele é listado num rol de ações para materializar em política pública e política pública é ação e não é fala, fala é para academia de diletante, inclui o papel também. Então aqui é ação! Um rol para garantir a ampliação de saúde primaria; E assim, não foi nada autoritário, Aí fica todo ENATESPO dizendo que um grupo 'PT-Comitê' não, nada de 'PT-Comitê'. As pessoas que historicamente se legitimaram no processo de luta e da disputa, estão lá. (Entrevistado 22, dentista, professor universitário)

Foram ainda citados os nomes de pessoas com o perfil desejado pelo grupo para assumir a Coordenação de Saúde Bucal: Gilberto Pucca Jr. (PR); Helenita Correa Ely (RS); Marco Antonio Manfredini (SP); Paulo Capel Narvai (SP); Renato César Ferreira (MG); e Rozangela Fernandes Camapum (DF). Uma comissão de representantes também foi escolhida para acompanhar o desenvolvimento desta proposta junto à Equipe de Transição do Governo, composta pelos membros: Cleber Ronald (Região Norte-AC); Gilberto Pucca Jr. (Região Sul-PR); José Carrijo Brom (Região Centro-Oeste-GO); Marco Antonio Manfredini (Região Sudeste-SP); Moacir Tavares Martins Filho (Região Nordeste-CE). (FOME..., 2002)

Quatro dias antes da realização da reunião de São Paulo (SP), foi realizada uma reunião em Belo Horizonte, em 20 de novembro de 2002, que também considerava o cenário sócio-político-econômico do país e trazia pautas a respeito da saúde bucal contemplando: articulação com as outras políticas de saúde, alicerce no conceito ampliado de saúde, discussão sobre a política no âmbito da III CNSB, participação e controle popular, proposição de ações para todas as faixas etárias, reorganização da urgência e emergência, prevenção e combate ao câncer bucal, educação permanente, papel e função social das universidades e centros formadores, finalização e divulgação do SB-Brasil 2000, financiamento, discussão sobre o sistema supletivo e sugeria o perfil de coordenador político e com grande capacidade de articulação com bom trânsito intersetorial. Por fim, parabeniza- 
va a iniciativa dos companheiros quanto à convocação da reunião de São Paulo. (CARTA..., 2002)

Ainda no mesmo mês, em 27 de novembro de 2001, os representantes da FIO, José Carrijo Brom, presidente da entidade, juntamente com Rozângela Camapum e outros membros se reuniram com Swendenberger Barbosa, membro da equipe de transição do presidente eleito, e com Humberto Costa, coordenador de Assuntos Sociais da equipe que se comprometeram a incluir as propostas no relatório de transição. Dentre as pautas, constavam: a elaboração de uma política nacional para modificar a saúde bucal no SUS; fortalecer a coordenação nacional; estreitar a relação com estados/municípios e uma atuação mais política no MS; integrar a coordenação aos Conselho Nacional de Saúde, Plenária Nacional dos Conselheiros, Enatespo e MEC, dentre outros; reafirmar a fluoretação das águas de abastecimento; equiparação da equipe de saúde bucal e saúde da família com carga horária semanal de 40 horas; incentivar estados e municípios a criarem centros de referências de especialidades; garantir a realização do SB-Brasil 2000 e espaços institucionais para inserção de programas de educação em saúde bucal; elaborar sistema de informação; incentivar as áreas técnicas de saúde bucal de estados e municípios a participarem dos Conselhos de Saúde; aprovação do Projeto de Lei para regulamentação das profissões auxiliares; integrar com o MEC e inserir no currículo escolar os conceitos e práticas de SB; criar polos de capacitação nos estados e municípios; assim como realizar a III CNSB.

Algumas destas pautas constam no volume especial publicado pelo MBRO na revista Saúde em Debate, em 1986, assim como em outros boletins do Movimento, como a fluoretação das águas, a regulamentação do pessoal auxiliar assim como a inserção de conteúdos sobre saúde bucal nos currículos das escolas. (BARBOSA, 1986; BOLETIM INFORMATIVO DO MOVIMENTO BRASILEIRO DE RENOVAÇÃO ODONTOLÓGICA, 1985) Constam também defesas dos Enatespo como as citadas, além dos centros de referências em especialidades, o sistema de informação e a integração das áreas técnicas dos estados e municípios com o MS.

Em dezembro do mesmo ano, Humberto Costa, que já havia sido definido como o futuro ministro da Saúde, afirmou que o PSF seria uma prioridade em sua gestão. Acrescentou que daria prioridade às questões de saúde bucal citando que o presidente Lula atribuíra a ele a responsabilidade de "cuidar da saúde bucal do povo”. (NINOMURA, 2002, p. A7)

Após o presidente Lula ter sido empossado, as negociações seguiram, quanto ao cargo da coordenação, tendo exercido um papel importante Petrônio Martelli, professor do Departamento de Medicina Social da UFPE. Segundo um Entrevis- 
tado 23, dois nomes da lista citada representavam alternativas reais ao cargo de Coordenação de Saúde Bucal: Rozângela Camapum e Gilberto Alfredo Pucca Jr. A primeira declinou a indicação por questões pessoais, tendo ficado o segundo como sugestão do grupo que havia se reunido em São Paulo. Petrônio Martelli apoiou a indicação de Gilberto Pucca junto ao primeiro ministro da Saúde do governo Lula, Humberto Costa do PT-PE.

Outra reunião ocorreu com um subgrupo dos cirurgiões-dentistas que participaram da formulação do documento Fome Zero e Boca Cheia de Dentes no $21^{\circ}$ Congresso Internacional de Odontologia de São Paulo (CIO-SP), ocorrido de 27 a 30 de janeiro na capital.

A Área Técnica de Saúde Bucal voltou a se denominar enquanto coordenação, ${ }^{93}$ desta vez, como "Coordenação Nacional de Saúde Bucal” pelos novos arranjos institucionais ao interior do Ministério e, em março de 2003, o dr. Gilberto Pucca se tornou o gestor. Após ter assumido o cargo, Gilberto Pucca, através da Portaria $n^{\circ} 36$, de 14 de janeiro de 2004, constituiu a Comissão de Assessoramento da Coordenação Nacional de Saúde Bucal, um grupo de 13 pessoas de diferentes estados para dar seguimento à formalização da PNSB no ano seguinte. Faziam parte da comissão: Cleber Ronald Inácio dos Santos (Secretaria de Saúde do Estado do Acre); Christian Mendez Alcântara (Universidade Federal do Pará - UFPA); Helenita Corrêa Hely (Secretaria Estadual de Saúde do Rio Grande do Sul); Idiana Luvison (Grupo Hospitalar Conceição).

Também integraram a comissão José Carrijo Brom (Secretaria Municipal de Saúde de Goiânia (GO)); Marco Aurélio Peres (Departamento de Saúde Pública da Universidade Federal de Santa Catarina - UFSC); Marco Manfredini (Secretaria Municipal de Saúde de São Paulo - SP); Marcos Azeredo Furquim Werneck (Faculdade de Odontologia da Universidade Federal de Minas Gerais - UFMG); Mauro Rubem de Menezes Jonas (Secretaria Estadual de Saúde de Goiás); Moacir Tavares Martins Filho (Universidade Federal do Ceará - UFC); Paulo Capel Narvai - FSP/USP); Petrônio Martellli (Departamento de Saúde Coletiva do Centro de Pesquisa Aggeu Magalhães da Fundação Oswaldo Cruz, do Ministério da Saúde); e Rozângela Camapum (Secretaria de Saúde do Distrito Federal).

Os participantes da Comissão da reunião de São Paulo contemplaram representantes de todas as regiões do país. Andrade (2008) aponta que a conformação do grupo se fundamentou no triedro saber/ideologia/prática política. Com isto, a autora quis dizer que estavam contemplados profissionais do serviço, da academia, do movimento sindical e da militância política. Em junho/julho de 2003, o

No governo Collor, a DNSB passou a se denominar Coordenação de Saúde Bucal. 
grupo se reuniu novamente para desenhar a política. Idiana Luvison e Helenita Ely fizeram um esboço inicial do documento, a partir da experiência do estado do Rio Grande do Sul e o enviaram para que os outros membros pudessem contribuir. Outros documentos consultados foram protocolos e políticas de saúde bucal de outros locais, como Curitiba e São Paulo.

A comissão estabeleceu longos debates com periodicidade mensal para a efetivação dos termos das diretrizes políticas do novo governo, tendo chegado à conformação de um esboço para a reunião que se realizou no II Fórum Internacional de Saúde Bucal, organizado pela FIO, realizado em Campo Grande, de 12 a 15 de novembro de 2003, onde se obteve o primeiro documento com as Diretrizes da política Brasil Sorridente. A participação das entidades de classe no processo de formulação da política foi limitada à atuação no campo político, com exceção da Fio, que tinha alguns representantes na comissão de assessoramento para construção da política.

Em seguida, o documento foi analisado pelas coordenações estaduais e apresentado ao Conselho Nacional de Saúde (CNS), na $139^{\circ}$ reunião ordinária, de 4 a 6 de fevereiro de 2004. Na reunião seguinte do CNS, realizada nos dias 10 e 11 de março de 2004, foram apresentadas as propostas para a III CNSB, tendo sido aprovado, por unanimidade, o nome de Paulo Capel Narvai para relator-geral da Conferência. O Plenário referendou a composição da Comissão-Executiva proposta pelo ministro da Saúde, a saber: coordenador-geral: Gilberto Alfredo Pucca Júnior; coordenadora-adjunta: Idiana Luvison; secretário-geral: José Carrijo Brom; e secretário-adjunto: Marco Azevedo F. Werneck. Todos os dentistas mencionados integravam a comissão de assessoramento do coordenador Gilberto Pucca Jr. O coordenador nacional recebeu apoio das entidades de classe, como ABO e CFO, que retratava em seu primeiro boletim de 2004 que "o governo estava muito comprometido com a saúde bucal”. (NOVA... 2004, p. 13)

A Política foi publicada em 17 de março de 2004, em Sobral, no estado do Ceará, com a presença dos presidentes das principais entidades odontológicas que homenagearam o então presidente pelo lançamento da política. (BOLETIM DA FEDERAÇÃO INTERESTADUAL DOS ODONTOLOGISTAS, 2004) O documento trata das diretrizes para a reorganização da atenção em saúde bucal em todos os níveis de atenção, baseada em uma concepção de saúde ampliada e tendo o cuidado como "eixo de reorientação do modelo". (BRASIL, 2004, p. 3) A qualificação da atenção básica, sua articulação com a rede de serviços e seu reconhecimento como estratégia na reorganização do modelo de atenção, a integralidade das ações, a utilização da epidemiologia e informações sobre o território para subsidiar as ações, o moni- 
toramento de indicadores, a vigilância à saúde, a definição de política de educação permanente para os trabalhadores, financiamento e agenda de pesquisa foram os pressupostos estabelecidos para a política nacional. (BRASIL, 2004)

Os princípios norteadores do documento são gestão participativa, ética, acesso, acolhimento, vínculo e responsabilidade profissional, com um processo de trabalho baseado em interdisciplinaridade e multiprofissionalismo, integralidade da atenção, intersetorialidade, ampliação e qualificação da assistência, condições de trabalho e parâmetros discutidos entre as coordenações de saúde bucal nacional e estaduais. (BRASIL, 2004)

As ações propostas se baseavam em: promoção e proteção da saúde na perspectiva de integrar a saúde bucal às demais práticas de saúde; fluoretação das águas; educação em saúde considerando diferenças sociais, peculiaridades culturais, integrando as ações educativas com as demais áreas, com sua realização pela equipe de saúde bucal; higiene bucal supervisionada; aplicação tópica de flúor; e ações de recuperação e de reabilitação. $O$ documento situa, ainda, na ampliação e qualificação da atenção básica, a prevenção e controle do câncer bucal, a implantação e o aumento da resolutividade do pronto-atendimento, a inclusão de procedimentos mais complexos, como pulpotomias, restaurações em cavidades mais complexas, pequenas fraturas dentárias e instalação de próteses elementares, assim como a inclusão da reabilitação protética na atenção básica. Foi proposto o modelo baseado nas linhas de cuidado, em faixas etárias e por condições de vida, como em gestantes, na tentativa de superar o modelo biomédico de atenção às doenças. Por fim, a política trata da ampliação e qualificação da atenção secundária e terciária em saúde bucal e referenda a estratégia de saúde da família. (BRASIL, 2004)

Os entrevistados atribuem ao apoio do presidente Luiz Inácio Lula da Silva, como o maior agente facilitador da formulação e implementação da política, assim como ao histórico de militância política, inserção no campo científico e odontológico do grupo de formuladores. Outro fator de importância foi a habilidade na condução do processo de formulação pelo coordenador nacional.

O Humberto Costa [então Ministro da Saúde] foi chamado pelo Lula, e o Lula disse: - Eu quero que na área de saúde quatro coisas tenham prioridade: que ninguém morra por falta de atendimento de urgência (criou SAMU), que não falte medicação para as pessoas básicas (criou o Farmácia Popular), que os hospitais e serviços públicos sejam melhores do que são, mais acolhedores, precisa uma ampla qualificação, e a saúde bucal, que as pessoas não podem ter mais esse quadro de campeão desdentados. (Entrevistada 11, dentista, professora) 
Narvai e Frazão (2008b) também apontaram aspectos relacionados às suas trajetórias com ponto de partida popular, tendo sofrido com urgências odontológicas, como relevantes para seu apoio e a priorização da política. Os autores apontam a saúde bucal retratada em discursos do presidente. O exposto pode ser exemplificado em notícia do jornal Estado de São Paulo, de 9 de outubro de 2004, quando da inauguração do Centro de Especialidades Odontológicas, em Londrina.

No período desta política, observou-se articulação de agentes de distintos campos sociais na formulação da política Brasil Sorridente, no nível nacional. Destaca-se, também, a submissão do PL n 1.537/2003, na Câmara dos Deputados, que dispunha sobre a regulamentação das Profissões de Técnico e Auxiliar em Saúde Bucal, pelo deputado Feu Rosa, do PSDB do Espírito Santo (Quadro 19).

Quanto ao financiamento no período 2003-2010, observou-se aumento do planejamento de recursos, no primeiro governo, e manutenção, no segundo mandato (Tabela 5). Ressalta-se que o orçamento da União e do Ministério da Saúde se elevaram bastante, mas a proporção do aumento não se refletiu na saúde bucal, ainda que tenha ocorrido aumento nos valores planejados para a saúde bucal. Outro ponto de destaque é a inclusão da rubrica relativa à atenção especializada no orçamento, inexistente nos períodos anteriores (Tabela 5). 


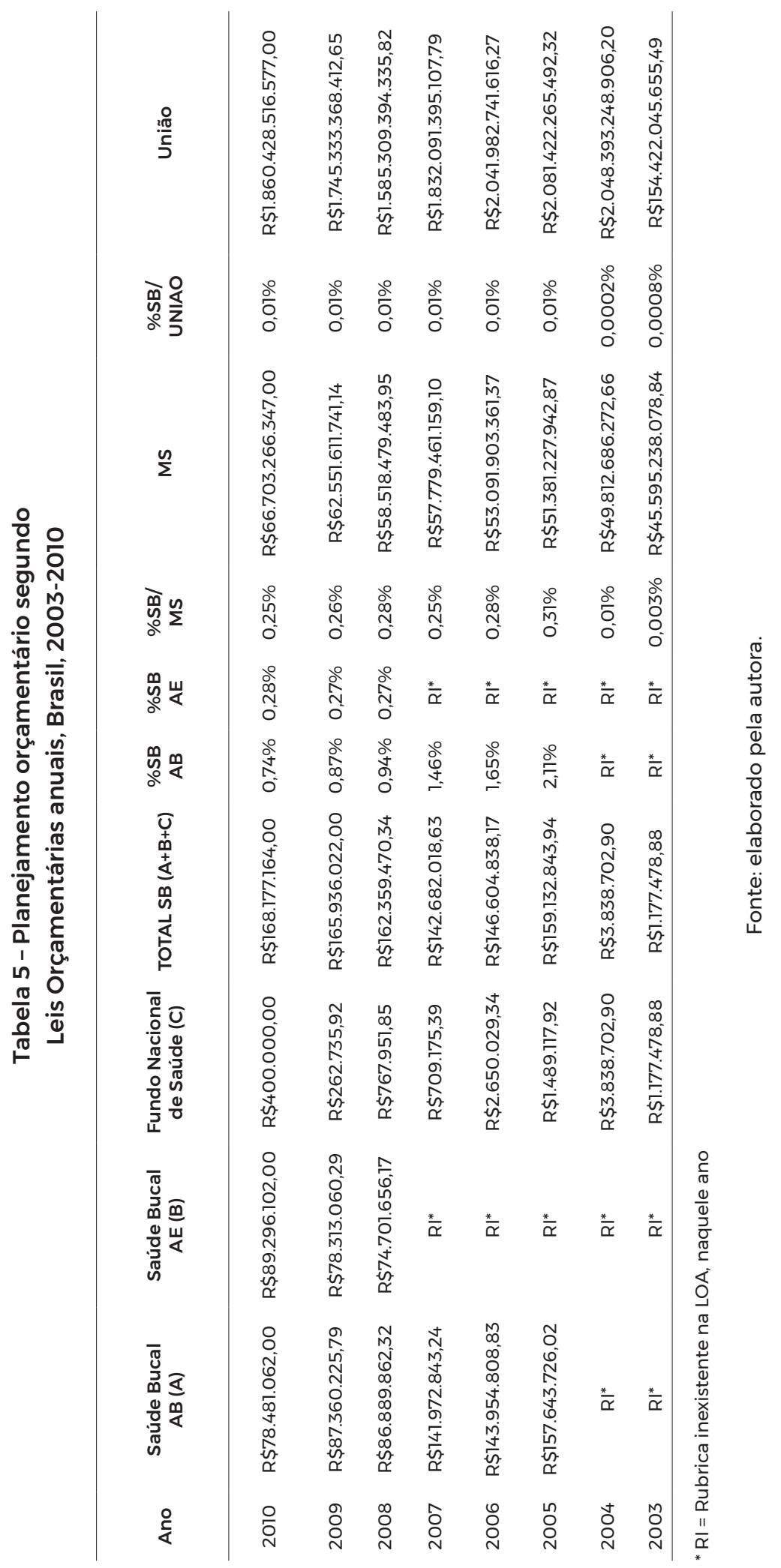

Produção Social da Políticas de Saúde Bucal no Brasil / 189 


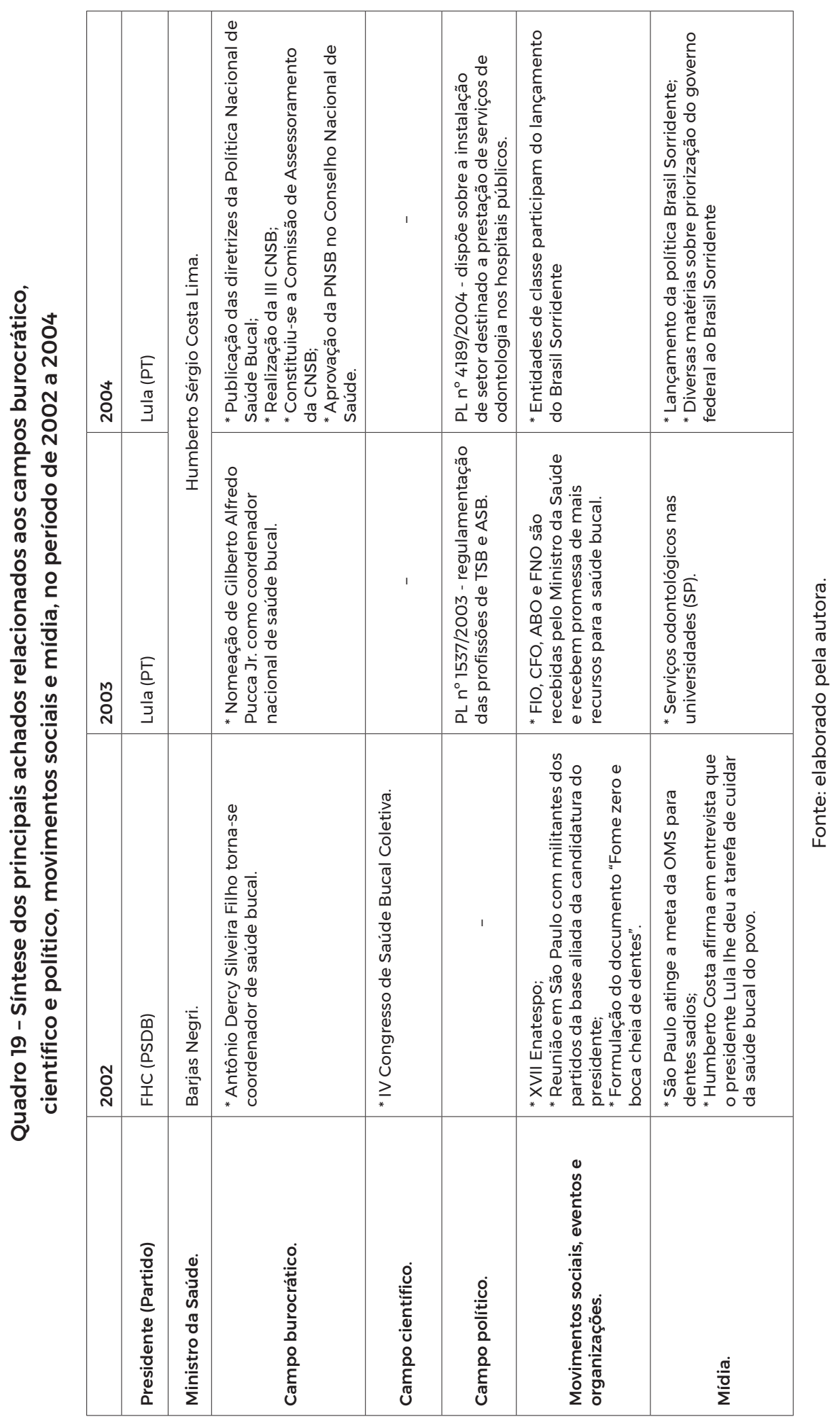




\section{Análise dos participantes e críticos do espaço de formulação das políticas de saúde bucal}

A Política Nacional de Saúde Bucal (Brasil Sorridente) foi formalizada por meio da publicação das diretrizes, em 2004. Oriunda de articulação inicial no interior do campo político, contou com a participação de membros de partidos políticos (PT, PC do B e PSB) que eram dentistas, muitos que haviam participado do MBRO, dos Enatespo, subespaços onde se desenvolveu um pensamento crítico acerca das políticas de saúde bucal, desde a década de 1980. Um dos dentistas, que era do PT, participava da equipe de transição do governo. Swendenberger Barbosa do Nascimento representou uma aliança e apoio da política de saúde bucal também no campo político assim como a aceitação e a sustentação da política pelo ex-presidente Luiz Inácio Lula da Silva foi fundamental para a priorização conferida à política Brasil Sorridente em seu governo (Quadro 20).

No grupo de entrevistados, quatro participantes eram mulheres e sete eram homens. Apesar da maioria da amostra de entrevistados ser representada pelos homens, isto não tem correspondência necessária com o universo, dado ser uma amostra qualitativa. Há indícios de que foi crescente a participação das mulheres no espaço de formulação das políticas de saúde bucal assim como o número de cirurgiãs-dentistas inscritas no Conselho Federal de Odontologia também aumentou.

Dentre os entrevistados, nove participaram da formulação da política e um deles fazia parte do espaço de crítica e também participava dos Enatespo e da Abrasbuco, mas não participou da escrita do documento. A Abrasbuco também não é considerada partícipe do processo de formulação desta política. O presidente do CFO não participou da formulação da política, mas aliou-se ao grupo, manifestando apoio e aglutinando aliados no campo legislativo e junto às outras entidades odontológicas. 


\begin{tabular}{|c|c|c|c|c|c|c|c|c|c|c|c|}
\hline 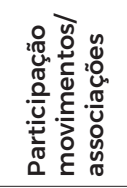 & 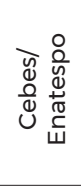 & & 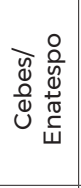 & O & 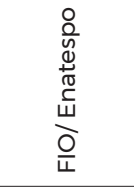 & 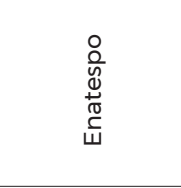 & $\begin{array}{l}8 \\
\frac{0}{0} \\
\stackrel{0}{ \pm} \\
\frac{\pi}{5} \\
\Psi\end{array}$ & 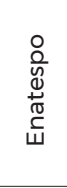 & $\begin{array}{l}\frac{0}{0} \\
\frac{0}{0} \\
\mathbb{d} \\
\tilde{0} \\
w\end{array}$ & $\begin{array}{l}8 \\
\frac{0}{0} \\
\stackrel{0}{0} \\
\frac{0}{5} \\
\Psi\end{array}$ & $\begin{array}{l}\frac{8}{0} \\
\frac{8}{0} \\
\frac{1}{\pi} \\
\frac{1}{w}\end{array}$ \\
\hline 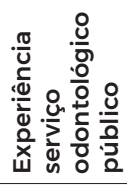 & ह & 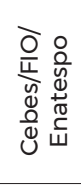 & $\frac{\varepsilon}{n}$ & $\frac{\varepsilon}{n}$ & $\frac{\varepsilon}{i n}$ & $\frac{\varepsilon}{n}$ & $\frac{\varepsilon}{i n}$ & $\frac{\varepsilon}{i n}$ & $\frac{\xi}{n}$ & $\frac{\varepsilon}{i n}$ & $\frac{\varepsilon}{i n}$ \\
\hline 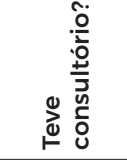 & $\frac{20}{2 \pi}$ & $\frac{\varepsilon}{i n}$ & $\frac{\varepsilon}{n}$ & $\frac{\varepsilon}{\omega n}$ & $\frac{E}{n}$ & $\frac{\varepsilon}{n}$ & $\frac{\varepsilon}{n}$ & $\frac{\varepsilon}{i n}$ & $\frac{0}{2 \pi}$ & $\underset{2 \pi}{Z}$ & $\frac{\varepsilon}{n}$ \\
\hline 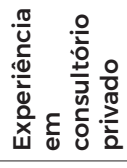 & $\frac{20}{2 \pi}$ & $\frac{\varepsilon}{n}$ & ह & $\frac{\varepsilon}{n}$ & $\frac{\varepsilon}{n}$ & $\frac{\varepsilon}{n}$ & $\frac{\varepsilon}{i n}$ & $\frac{\varepsilon}{i n}$ & $\underset{2 \pi}{2 \pi}$ & $\underset{20}{2 \pi}$ & $\frac{\varepsilon}{n}$ \\
\hline 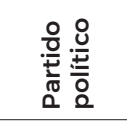 & 占 & $\frac{\xi}{i n}$ & 占 & 5 & 占 & 占 & $\underset{2 \pi}{2}$ & เ & 占 & 占 & $\stackrel{2 \pi}{Z}$ \\
\hline 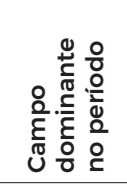 & 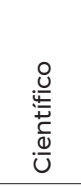 & 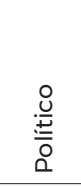 & $\begin{array}{l}0 \\
\frac{0}{0} \\
\frac{0}{0} \\
\frac{1}{0} \\
\frac{0}{0} \\
0\end{array}$ & 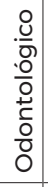 & 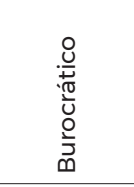 & 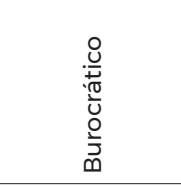 & 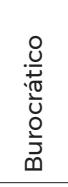 & $\begin{array}{l}0 \\
\frac{8}{0} \\
\frac{0}{0} \\
\frac{0}{0} \\
\frac{0}{0} \\
0\end{array}$ & 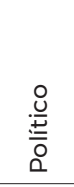 & 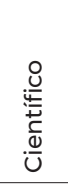 & 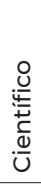 \\
\hline 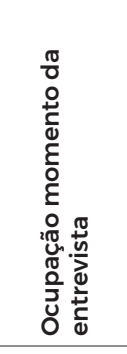 & 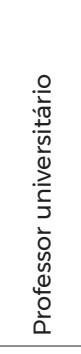 & 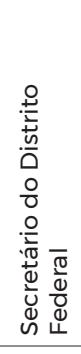 & 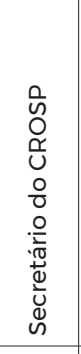 & 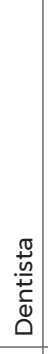 & 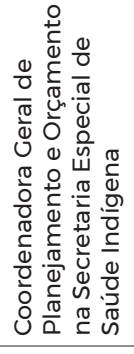 & 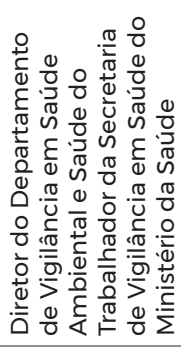 & 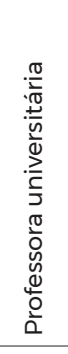 & 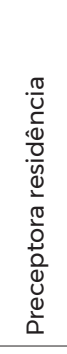 & 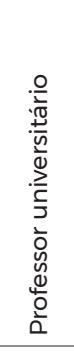 & 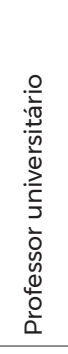 & 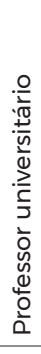 \\
\hline 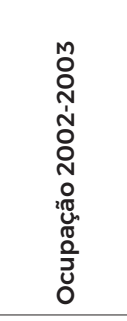 & 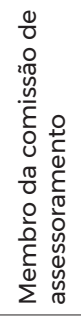 & 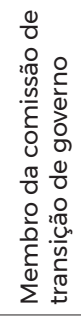 & 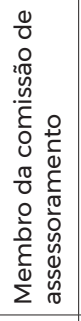 & 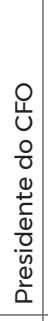 & 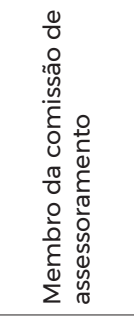 & 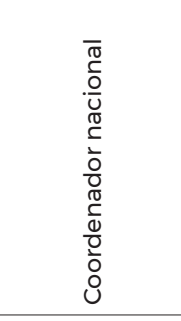 & 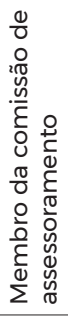 & 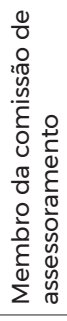 & 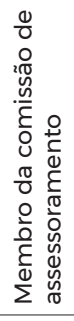 & 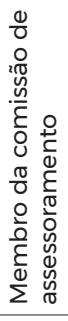 & 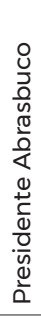 \\
\hline 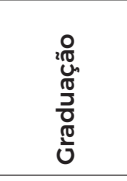 & $\begin{array}{l}\frac{\sigma}{0} \\
\frac{0}{0} \\
\frac{0}{2} \\
\frac{0}{0} \\
0\end{array}$ & $\begin{array}{l}\frac{\pi}{\pi} \\
\frac{0}{0} \\
\frac{1}{0} \\
0 \\
0 \\
0\end{array}$ & $\begin{array}{l}\frac{\pi}{\pi} \\
\frac{0}{0} \\
\frac{1}{0} \\
\frac{0}{0} \\
0\end{array}$ & $\begin{array}{l}\frac{\pi}{2} \\
\frac{0}{0} \\
\frac{0}{0} \\
\frac{0}{0} \\
0\end{array}$ & $\begin{array}{l}\frac{\pi}{7} \\
\frac{0}{0} \\
\frac{0}{0} \\
\frac{0}{0} \\
0\end{array}$ & $\begin{array}{l}\frac{\pi}{7} \\
\frac{0}{0} \\
\frac{0}{0} \\
\frac{0}{0} \\
0\end{array}$ & $\begin{array}{l}\frac{\pi}{\overline{0}} \\
\frac{0}{0} \\
\frac{0}{0} \\
\frac{0}{0} \\
0\end{array}$ & $\begin{array}{l}\frac{\pi}{0} \\
\frac{0}{0} \\
\frac{0}{0} \\
\frac{0}{0} \\
0\end{array}$ & $\begin{array}{l}\frac{\sigma}{0} \\
\frac{0}{0} \\
\frac{0}{2} \\
\frac{0}{0} \\
0 \\
\end{array}$ & $\begin{array}{l}\frac{\pi}{\overline{0}} \\
\frac{0}{0} \\
\frac{0}{0} \\
\frac{0}{0} \\
0\end{array}$ & $\begin{array}{l}\frac{\pi}{7} \\
\frac{0}{0} \\
\frac{1}{0} \\
\frac{0}{0} \\
0\end{array}$ \\
\hline $\begin{array}{l}\text { 㐘 } \\
\text { 元 } \\
\underline{0}\end{array}$ & 6 & ڤొ & it & ং & กิ & ก & $\tilde{\sigma}$ & น็n & $\stackrel{\circ}{+}$ & $\stackrel{\infty}{+}$ & $\stackrel{ \pm}{N}$ \\
\hline 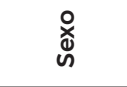 & $\begin{array}{l}\dot{u} \\
\sum^{\pi} \\
\Sigma\end{array}$ & 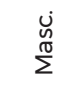 & $\begin{array}{l}\dot{u} \\
\substack{0 \\
\Sigma}\end{array}$ & $\begin{array}{l}\dot{\varepsilon} \\
\dot{\omega}\end{array}$ & $\underset{⿱ 亠 凶}{\dot{\psi}}$ & 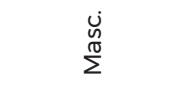 & $\underset{\varpi}{\dot{\varepsilon}}$ & $\begin{array}{l}\dot{\varepsilon} \\
\dot{\nu}\end{array}$ & $\begin{array}{l}\dot{u} \\
\sum^{\pi}\end{array}$ & $\begin{array}{l}\dot{u} \\
\dot{w} \\
\sum\end{array}$ & $\begin{array}{l}\dot{u} \\
\dot{w} \\
\sum\end{array}$ \\
\hline ш & 으 & $\stackrel{M}{N}$ & ㅇ & $\bar{m}$ & $m$ & 品 & 6 & $=$ & $\infty$ & $\hat{N}$ & ำ \\
\hline
\end{tabular}


No grupo que formulou a política, existe um consenso quanto às tomadas de posição. Foi referido que a PNSB representa a articulação da saúde bucal com as demais políticas de saúde no Sistema Único de Saúde, levando em consideração os determinantes sociais. $O$ consenso pode ser explicado devido à aproximação do grupo quanto à participação em movimentos como o movimento sanitário, MBRO, ECEO, ENATESPO, além de terem debatido estas pautas ao longo dos anos, conforme mencionado.

No primeiro documento editado pelo grupo que participou da reunião em São Paulo, existiam dentistas que exerciam a profissão em consultório privado, em serviços odontológicos públicos, professores universitários e gestores, o que se manifestou na representação dos graus de acumulação de capital nas Figuras 20, 21 e 22. Isto contribuiu para que a política fosse legitimada nos campos burocrático e político, mas, também, no odontológico liberal e científico, com diversas publicações.

A formulação da política foi feita por profissionais com inserção predominante nos campos político, científico e burocrático. Quanto aos cargos no campo burocrático, muitos já possuíam experiência em distintos âmbitos da gestão. O coordenador nacional de Saúde Bucal apresentava alto capital político e burocrático, mas baixo capital científico, à época. Observou-se proximidade nas posições ocupadas assim como nos capitais burocrático e político entre os membros da Comissão de Assessoramento e o coordenador nacional de Saúde Bucal.

$\mathrm{Na}$ Comissão de Assessoramento, o grupo também apresenta proximidade quanto aos capitais científico e burocrático, com exceção do Entrevistado 10, que apresentou maior capital científico que os demais.

Todos os membros da referida comissão apontaram que existiu consenso na formulação da política, tendo sido postas na agenda do Estado as pautas do MBRO, dos Enatespo, das CNSB, dos ECEO, entretanto, ocorreram críticas de agentes que ficaram fora do processo político pertencentes ao campo científico, como Entrevistado 24.

A formulação da política Brasil Sorridente assim como das outras analisadas neste estudo são consistentes com a proposição de Pinell (2010), segundo quem a construção social de um problema bem como a formulação da política correspondente é um processo determinado pelas alianças que vão se conformando entre os grupos sociais que têm interesse no reconhecimento do problema, sem significar que tenham o mesmo ponto de vista sobre o que ele é bem como em relação às medidas a serem tomadas. A aliança implica a negociação da definição do problema. Isso é notável na aliança entre as entidades de classe, a coordenação nacional e os 
grupos de assessoramento na política Brasil Sorridente e na inclusão da equipe de saúde bucal no PSF. Ainda que por motivações distintas, o interesse de reconhecimento do problema fez com que os grupos entrassem em acordo quanto à definição do problema.

\section{Quadro 21 - Entrevistado, concepção do SUS, origem social, sentido da trajetória, local de nascimento}

\begin{tabular}{|c|l|c|c|c|c|c|c|}
\hline E & Concepção SUS & Origem Social & $\begin{array}{c}\text { Sentido da } \\
\text { Trajetória }\end{array}$ & Local Nasc. & $\begin{array}{c}\text { Colégio } \\
\text { Secundário }\end{array}$ & $\begin{array}{c}\text { Região } \\
\text { Estudantil }\end{array}$ & Sim \\
\hline 10 & SUS democrático & Popular & Ascendente & Interior & Público & Sul & Não \\
\hline 23 & SUS democrático & Média & Ascendente & Capital & Público & Nordeste & Sudeste \\
\hline 20 & SUS democrático & Popular & Ascendente & Capital & Privado & Sul & Não \\
\hline 31 & SUS para pobres & Popular & Ascendente & Interior & Privado & Sim \\
\hline 33 & SUS democrático & Média & Estável & Interior & Privado & Centro-Oeste & Sim \\
\hline 6 & SUS democrático & Popular & Ascendente & Interior & Público & Sul & Sim \\
\hline 11 & SUS democrático & Popular & Ascendente & Interior & Privado & Sul & Sim \\
\hline 8 & SUS democrático & Popular & Ascendente & Capital & Privado & Nordeste & Sim \\
\hline 27 & SUS democrático & Popular & Ascendente & Interior & Público & Sudeste & Sim \\
\hline 29 & SUS democrático & Popular & Ascendente & Interior & Público & Sul & Sim \\
\hline
\end{tabular}

Fonte: elaborado pela autora.

A concepção sobre o SUS democrático ligada à redefinição do modelo assistencial dominou o espaço de formulação da PNSB, contudo, a concepção de SUS para pobres esteve presente no discurso do CFO (Quadro 21).

Apesar de referirem se sentir melhor em distintos locais de trabalho como a sala de aula ou o consultório, o serviço público odontológico ou, ainda, o Conselho Nacional de Saúde e o Ministério da Saúde, a maioria se autodeclarava cirurgião-dentista na ficha do hotel. 


\section{Quadro 22 - Entrevistado, segundo distribuição e volume dos capitais científico, político e burocrático}

\begin{tabular}{|c|c|c|c|c|c|c|c|c|c|c|c|c|c|c|c|c|}
\hline E & \multicolumn{3}{|c|}{ Capital Científico } & \multicolumn{5}{c|}{ Capital Político } & \multicolumn{5}{c|}{ Capital Burocrático } & \multicolumn{2}{c|}{$\begin{array}{c}\text { Volume } \\
\text { total }\end{array}$} \\
\hline & & $\uparrow$ & $\uparrow \uparrow$ & $\uparrow \uparrow \uparrow$ & $\uparrow \uparrow \uparrow$ & & $\uparrow$ & $\uparrow \uparrow$ & $\uparrow \uparrow \uparrow$ & $\uparrow \uparrow \uparrow$ & & $\uparrow$ & $\uparrow \uparrow$ & $\uparrow \uparrow \uparrow$ & $\uparrow \uparrow \uparrow \uparrow$ & \\
\hline 10 & & & & & & & & & & & & & & & & 6 \\
\hline 23 & & & & & & & & & & & & & & & & 8 \\
\hline 20 & & & & & & & & & & & & & & & & 4 \\
\hline 31 & & & & & & & & & & & & & & & & 3 \\
\hline 33 & & & & & & & & & & & & & & & & 6 \\
\hline 30 & & & & & & & & & & & & & & & & 7 \\
\hline 6 & & & & & & & & & & & & & & & & 2 \\
\hline 11 & & & & & & & & & & & & & & & & 4 \\
\hline 8 & & & & & & & & & & & & & & & & 5 \\
\hline 27 & & & & & & & & & & & & & & & & 4 \\
\hline 29 & & & & & & & & & & & & & & & & 5 \\
\hline
\end{tabular}

Fonte: elaborado pela autora.

Figura 20 - Agentes segundo capitais burocrático e científico, 2002-2003

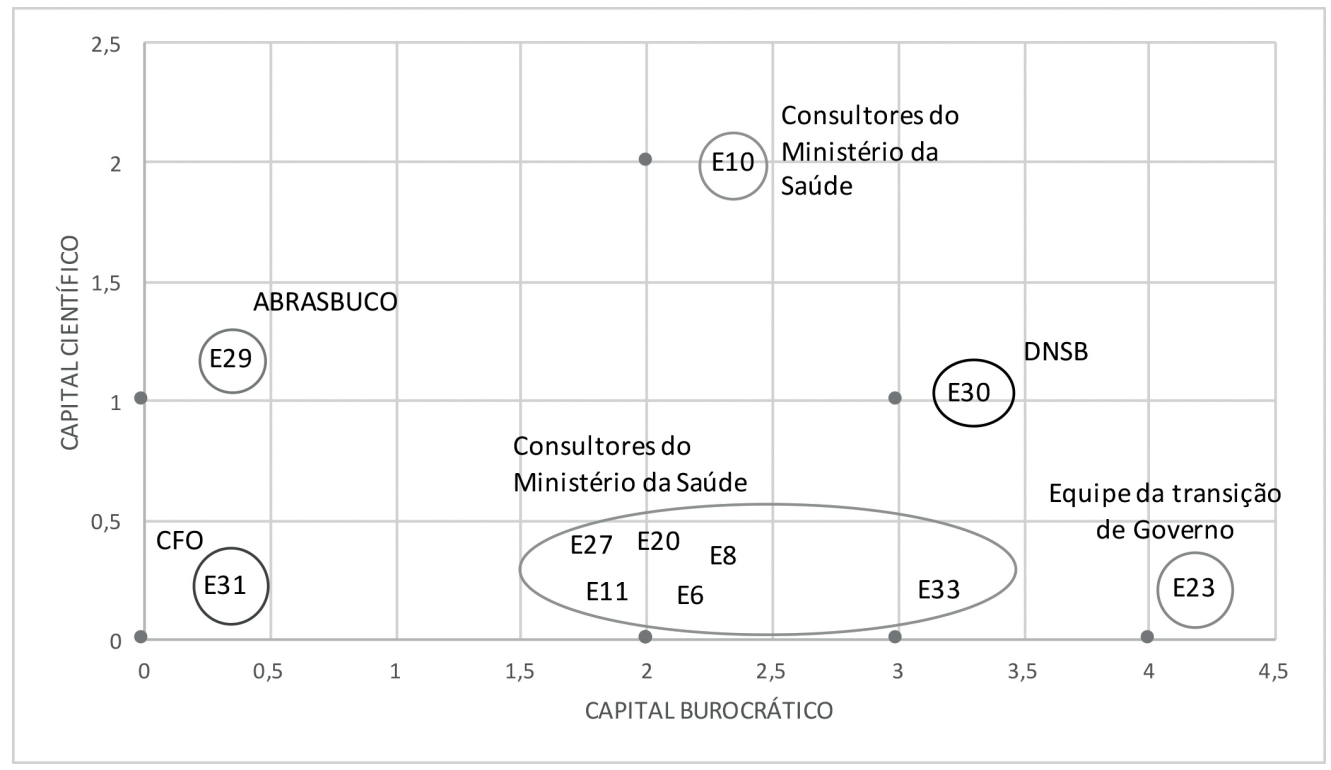

Fonte: elaborado pela autora. 
Figura 21 - Distribuição dos agentes segundo capitais burocrático e político, 2002-2003.

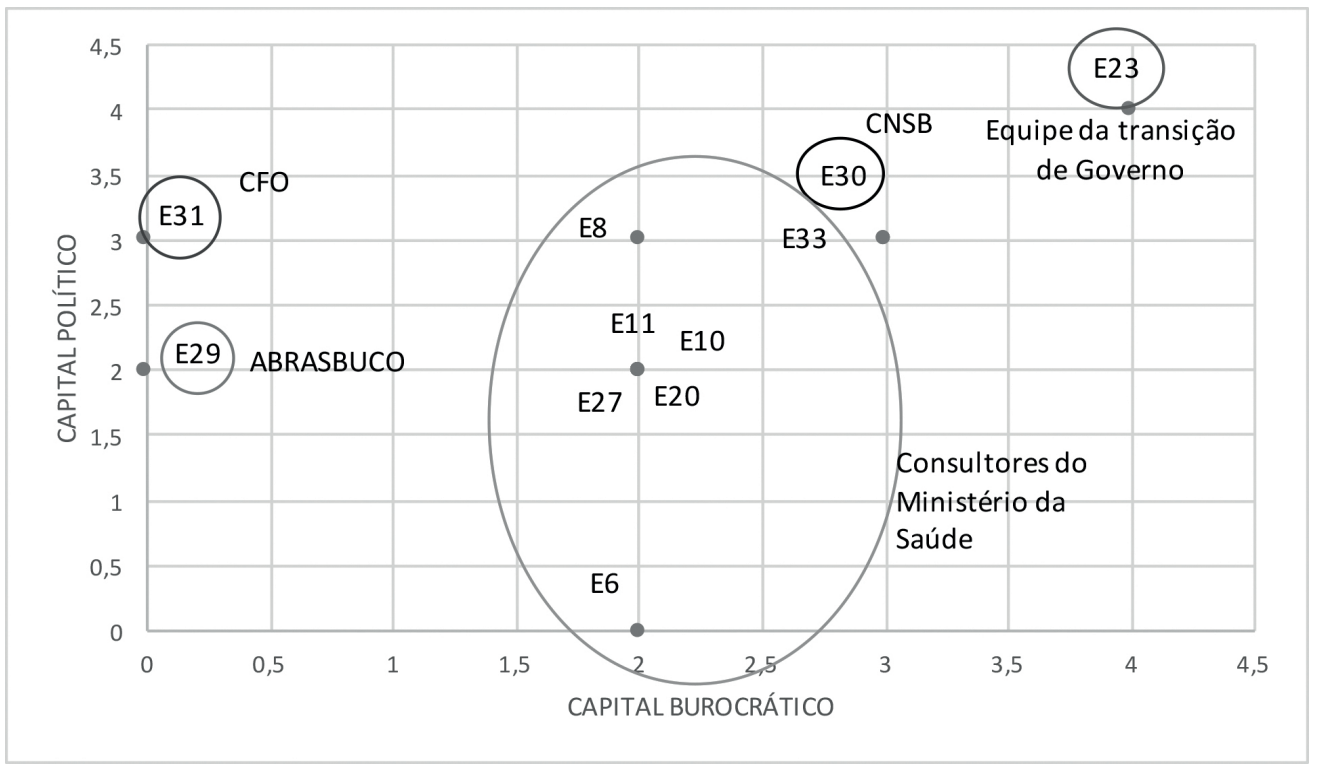

Fonte: elaborado pela autora.

Figura 22 - Distribuição dos agentes segundo capitais científico e político

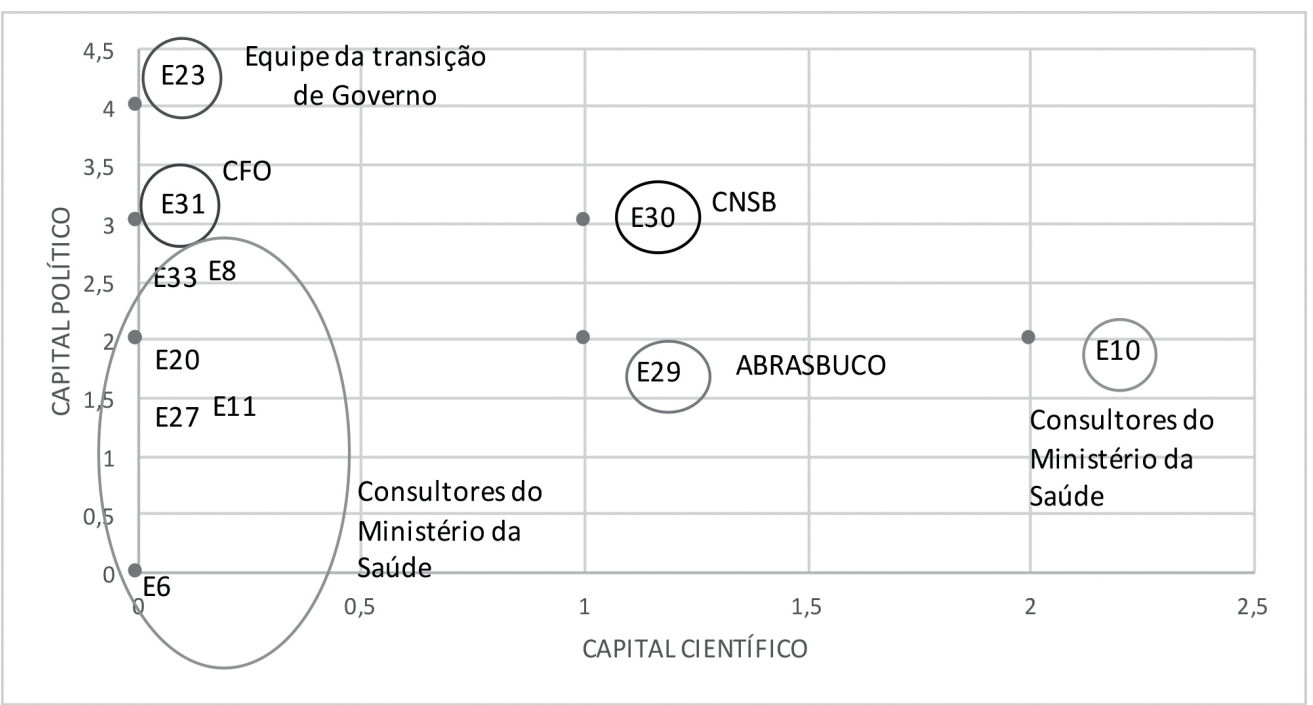

Fonte: elaborado pela autora. 
Dentre aqueles que participaram da Comissão de Assessoramento, a maioria nasceu no interior, é de origem popular, apresentou uma trajetória ascendente, participou de movimento estudantil e foi filiada a partidos políticos de esquerda.

As palavras mais referidas pelos entrevistados apontam para características do cenário sociopolítico e econômico. Novamente, saúde e bucal passam a figurar como palavra muito mencionada assim como nas políticas do período entre 2000 e 2001. Palavras como presidente e governo foram recorrentes. Os participantes da formulação da política apontam que o apoio do presidente foi fundamental na formulação e posteriormente na implementação da política.

Voltamos a história, voltando a história do Lula [...] você teve a indução grande de um presidente operário [...] Ou seja, ele queria saber (isso foi parte da história, eu vi, não foi que me falaram), queria sabe se o CEO ia atender com hora marcada, queria saber quantas pessoas iam ser atendidas, queria saber se o filho do 'não sei que lá' ia ser atendido, isso é demanda das pessoas que precisam de serviço, de usuário, do controle social, é isso! [...] mas não ocorre no governo Dilma. [...] Nenhum óbice contra a presente, muito pelo contrário, porém é uma questão de classe, quer dizer, quem vai procurar por saúde bucal? Isso para mim é uma coisa mensurável na área você tratando de orçamentos, você está tratando de prioridades, como é que faz? (Entrevistado 30, dentista, gestor) 
Figura 23 - Palavras mais frequentes a partir de cinco, seis, sete, nove, dez e onze letras
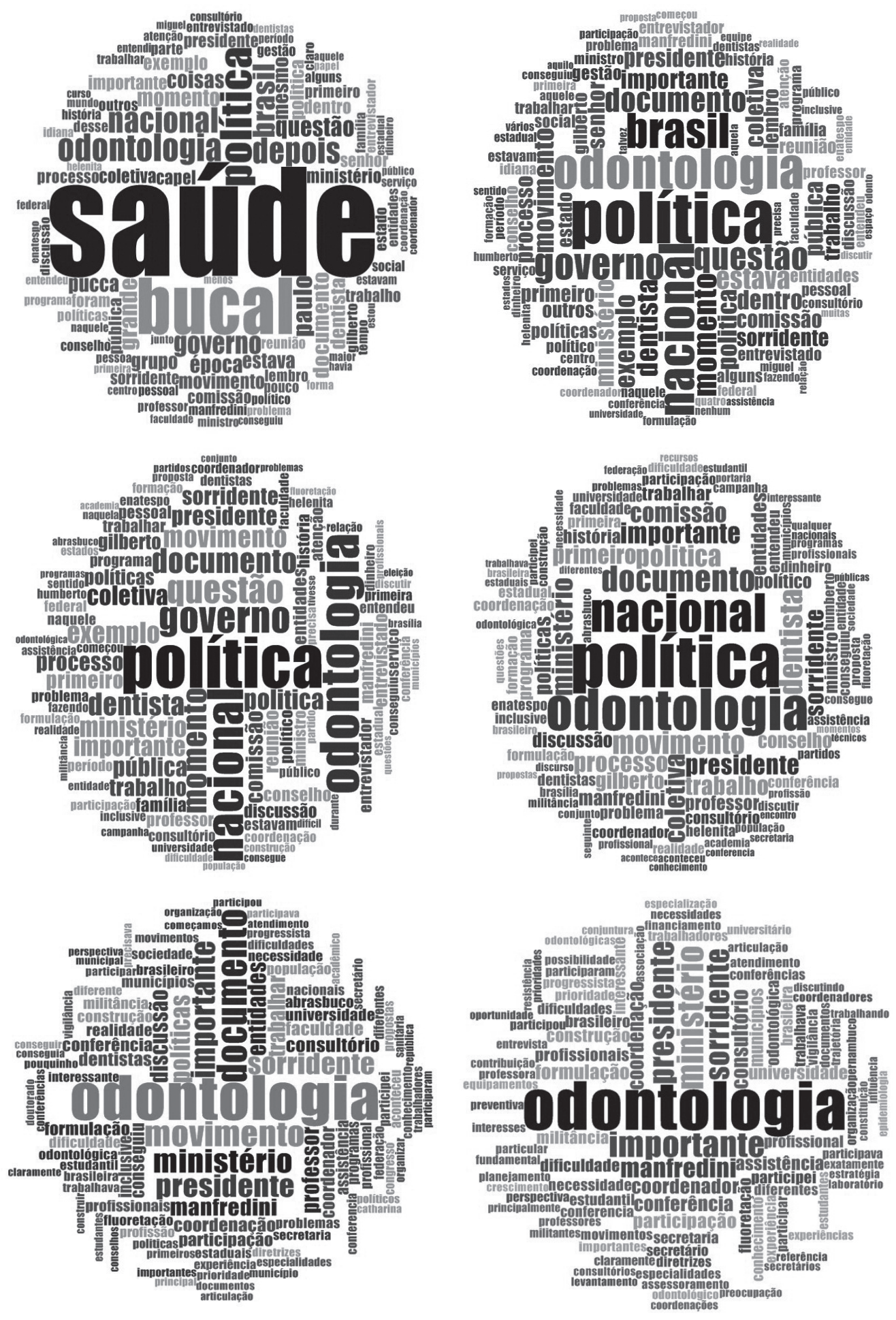

Fonte: elaborado pela autora. 


\section{CONSIDERAÇÕES FINAIS}

As políticas de saúde bucal no Brasil foram oriundas de um longo processo de construção por agentes inseridos em diversos campos e espaços sociais com interesses distintos, ao longo de um período que vai dos anos 1950 até o ano de 2004. A pequena prioridade dada a essas políticas se revela no montante destinado ao financiamento setorial cujos valores cresceram ao longo do tempo, porém foram insuficientes para o atendimento das necessidades nos períodos estudados, principalmente nos anos 1980 e 1990.

O espaço de formulação das políticas variou ao longo das diferentes conjunturas político-sanitárias, no período compreendido entre 1989 e 2004. Em concordância com Pinell (2010), o estudo dos quatro momentos históricos de formulação das políticas mostrou que o reconhecimento do problema cárie, inicialmente, e dos problemas de saúde bucal a posteriori, pelo poder público, exigiu que o Estado reassumisse uma análise preexistente do problema por agentes de distintos campos sociais. A construção desta resposta variou conforme a arquitetura do espaço e, principalmente, em função das características do(a) profissional que ocupava o cargo de coordenação nacional, seu campo de domínio, seu grau de acumulação de capital burocrático, político e científico. Assim, as questões em jogo, de certa forma, expressavam inadequação das orientações políticas anteriores assim como as práticas existentes nas instituições nos distintos cenários estudados.

O papel exercido pelo diretor/coordenador da divisão/área técnica/coordenação nacional de saúde bucal foi também importante pela dinâmica de alianças estabelecidas, pelo habitus específico oriundo do seu campo dominante que influenciou o reconhecimento do problema social a ser respondido pelo Estado na grande persistência pela aprovação de determinadas políticas, dentre outros. Aspecto também importante relacionado à influência que o gestor nacional pode ter exercido na formulação da política diz respeito ao seu grau de ajustamento com o 
campo burocrático e à acumulação de capital político. Todos foram indicados ao cargo em decorrência do capital social acumulado.

O espaço das políticas de saúde bucal se organizou, nos anos 1980, a partir de duas posições centrais: de um lado, o polo público, representado pelo IPEA, pela FSESP e pelo MS, tanto na oferta de atenção odontológica aos usuários quanto na proposição de medidas de impacto populacional como a fluoretação da água, do outro lado, o polo liberal e do mercado, representado pelas entidades de classe em defesa de seus interesses.

Ainda sobre a efemeridade persistente quanto às políticas em estudo, pode-se afirmar que se deveu também às mudanças no cenário político, como foi o caso da Política Nacional de Saúde Bucal, de 1989, e do Precad, no mesmo ano, e à inadequação à realidade brasileira, como foi o caso da fluoretação do sal de cozinha.

O problema socialmente construído foi a cárie, até meados da década de 1990, a despeito da emergência de um discurso sobre a saúde oral e saúde bucal desde os anos 1960. Até 1989, as políticas priorizaram a assistência odontológica aos trabalhadores da previdência com ênfase nas extrações. No que diz respeito à prevenção, as ações eram centradas no modelo utilizado pela FSESP, que preconizava o sistema incremental voltado, prioritariamente, aos escolares, com o objetivo de atender ao maior número de crianças baseado no tratamento recuperador, tratamento profilático-fluorterapia e tratamento radical (exodontias). A FSESP também atuou na fluoretação das águas.

A partir de 1984, começam a surgir movimentos de crítica à política nacional, com o MBRO assim como os Enatespo, como aglutinadores de tomadas de posição e desencadeadores de muitos processos de crítica às políticas, influenciados, em parte, pelo movimento da Reforma Sanitária Brasileira. Alguns dos membros do MBRO e dos Enatespo eram integrantes do Cebes e, posteriormente, da Abrasco. Alguns membros deste grupo participaram como consultores de distintas políticas.

O momento da política estudada, a Política Nacional de Saúde Bucal, publicada em 1989, apontou como ponto de vista predominante aquele da Odontologia Sanitária e Social, defendido pelo grupo da Faculdade de Saúde Pública da Universidade de São Paulo (FSP/USP), com exceção da fluoretação tópica através do uso de moldeiras que foi inspirado no método utilizado no Programa Integrado de Saúde do Escolar (PISE) do Distrito Federal.

No mesmo período, coexistiam outros pontos de vista, como o de crítica da prática odontológica vigente em uma perspectiva que discutia a determinação social dos problemas de saúde bucal e sua articulação ao movimento da Reforma Sanitária Brasileira, pelo grupo que compunha o MBRO e pelos Enatespo. Outra 
posição estava representada pelas principais entidades de classe: o Conselho Federal da Odontologia e a ABO, que defendiam a Odontologia Liberal. A política foi analisada por representantes de macrorregiões do país e apoiada pelas entidades de classe, não tendo passado por processo de discussão em conferências ou por outros representantes dos movimentos citados. Mesmo defendendo claramente a Odontologia Liberal, as entidades de classe vinham manifestando amplo apoio a todas as ações que envolviam o cirurgião-dentista no nível federal.

O espaço de formulação da PNSB de 1989 e do Precad se estruturou no Ministério da Saúde, tendo contribuído para a sua constituição agentes oriundos tanto do campo científico como burocrático. No primeiro caso, oriundos da FSP/USP e no segundo, da própria DNSB e do IPEA.

Apesar da busca por responder às críticas formuladas pelos integrantes do MBRO e Enatespo, a construção social do problema elaborada por estes pouco influenciou a formulação da política, com exceção do enquadramento nos princípios da Reforma Sanitária Brasileira pouco traduzidos nas ações preconizadas.

A construção do espaço de formulação das políticas no interior do Ministério da Saúde resultou em mudança do modelo praticado pelo Ministério da Previdência e Assistência Social assim como na própria lógica de formulação e implementação das políticas antes protagonizadas pelo IPEA e FSESP ainda com o objeto principal restrito ao dente e à cárie dentária. A estratégia de fluoretação das águas, a formação de recursos humanos e a vigilância e controle de produtos preventivos podem ser consideradas como os possíveis mortos desta política que, devido ao seu curto tempo de vigência, teve sua maior operacionalização e é lembrada pela fluoretação tópica através do uso em moldeiras.

As políticas de procedimentos coletivos e da tentativa de fluoretação do sal de cozinha foram as principais ações propostas pelo MS no período de 1990 a 1993. Devido à mudança no governo, envolvendo a DNSB, ocorreram mudanças no espaço de formulação das políticas que foi ocupado por agentes com trajetória dominante no campo científico e que substituíram a aplicação do flúor pela escovação supervisionada. O comitê de assessoramento do setor também passou a ser composto por agentes dominantes no campo científico, mas, também, por aqueles pertencentes ao campo burocrático estadual e municipal. A Aboprev exerceu influência no curso dessas políticas, seja através da presença de seus membros na DNSB ou de congressos e publicações no campo científico.

Apesar de constar no plano quinquenal do governo Collor, mesmo que de forma restrita, os objetos câncer de boca, cárie e doença periodontal, novamente observou-se, nas ações do governo, a continuidade do processo de trabalho 
voltado para o manejo da cárie como o principal problema social construído. Ainda que os procedimentos coletivos objetivassem proporcionar a prevenção de outras doenças bucais, seu foco principal também era a cárie dentária. A concepção da Odontologia Preventiva baseada na concepção ecológica e multifatorial da doença, defendida por profissionais do campo científico também pertencentes à Aboprev orientou a formulação dos procedimentos coletivos e a interrupção da PNSB de 1989 e do Precad.

A fluoretação do sal de cozinha, proposta pelo DNSB/MS, em parte influenciada pela OPAS, traduzia os interesses comerciais de empresas brasileiras produtoras de sal. Inicialmente considerada pela gestão da DNSB e consultores como estratégia alternativa de fluoretação sistêmica em regiões do Brasil que não contavam com água fluoretada, esta alternativa passou a ser condenada por eles, após a constatação da inviabilidade de sua implementação no Brasil. A estratégia obteve o apoio de membros da Rede Cedros/OPAS, do campo burocrático internacional e científico nacional, assim como de agentes do campo político, como deputados e senadores, por influência das empresas salineiras bem como do polo do mercado do espaço das políticas de saúde bucal. A oposição veio do grupo da saúde bucal coletiva, por meio dos integrantes dos Enatespo, que apresentavam disposições políticas, seja por filiação a partidos políticos ou em movimentos de luta pela saúde bucal.

A partir da segunda metade da década de 1990, novas mudanças começaram a ser realizadas no espaço de formulação das políticas de saúde bucal. A partir do capital social relacionado a gestor do Ministério da Saúde, oriundo do mesmo local de nascimento, uma dentista com especialização em saúde pública com carreira no campo burocrático assume a coordenação da Área Técnica de Saúde Bucal. Os membros do comitê técnico científico também são modificados, oriundos do campo burocrático e do campo científico. Alguns membros que participavam dos Enatespo passaram a integrar o Comitê, como Paulo Capel Narvai, Djalmo Sanzi Souza e Sylvio Palermo Gevaerd.

Depois, a partir de um grupo de agentes com inserções distintas nos campos burocrático, político e científico, devido à forte articulação das entidades odontológicas no campo político e ao longo processo de pactuação no interior do campo burocrático, concretizou-se a inclusão da equipe de saúde bucal no PSF.

Destaca-se o papel exercido pela FIO na articulação política com as entidades odontológicas e no interior do campo político com deputados e senadores que apoiaram a inclusão da pauta junto ao Ministro da Saúde, mas com cargos chave ocupados por agentes com militância na Reforma Sanitária Brasileira que acolheram 
as propostas de criação das ESB. Um destes profissionais com inserção nos campos burocrático e político representou a mediação entre as propostas elaboradas pelo CTC apresentadas pela coordenadora e o alto escalão do Ministério da Saúde. Aqui se observa a ruptura com os modelos preconizados anteriormente pelo Ministério da Saúde para resposta aos problemas de saúde bucal, tendo em vista que se baseavam na integralidade da atenção, caráter substitutivo das práticas desempenhadas nas unidades básicas de saúde, sistema de referência e contra referência, centralidade na família e no território, atuação em equipe multiprofissional e interdisciplinar e formalização da equipe de saúde bucal.

A última política analisada no presente estudo foi publicada em 2004, pelo Ministério da Saúde, tendo como título "Diretrizes da Política Nacional de Saúde Bucal”, conhecida como política "Brasil sorridente”. Uma nova mudança ocorreu no espaço de formulação das políticas: o novo grupo de agentes que compôs este espaço apresentava disposições e capital político vinculados à militância no PT e à base aliada na eleição do presidente Luiz Inácio Lula da Silva, em 2003.

Nesse período, a indicação do coordenador e do próprio conteúdo da política bem como da comissão de assessoramento sofreram influência do núcleo saúde do PT e das forças políticas que apoiaram a eleição de Lula. O coordenador foi fundamental na articulação política e no interior do campo burocrático para o curso da política. A comissão de assessoramento foi composta por cirurgiões-dentistas do campo científico e do campo burocrático. Esta comissão incorporou membros que haviam militado no MBRO, no Cebes, na Abrasco e nos Enatespo que puderam trazer detalhamento das estratégias para uma política nacional de saúde bucal, a partir de diretrizes gerais defendidas nesses movimentos e na Reforma Sanitária Brasileira.

Outro profissional de importância nesse espaço era membro da comissão de transição de governo. Ficou evidente o apoio fundamental do presidente Lula ao objeto saúde bucal, segundo entrevistado, devido a experiências de dor em sua trajetória com ponto de partida popular. Devido a este apoio, a Política Nacional de Saúde Bucal foi considerada como uma das prioridades deste governo.

De forma distinta dos outros documentos existentes das políticas de saúde bucal e representando uma nova ruptura, a política "Brasil Sorridente" expressa um conjunto de diretrizes e ações de articulação da saúde bucal com o SUS. Distingue-se das outras políticas por sua concepção ampliada de saúde, pela fundamentação nos determinantes sociais da saúde e no projeto da Reforma Sanitária Brasileira, pela articulação com as outras políticas de saúde no SUS e pelas propostas de conformação da rede, qualificação e ampliação da atenção primária e 
especializada. Entretanto, ela também formaliza políticas anteriores, como a fluoretação das águas de abastecimento, as estratégias de educação em saúde bucal e a incorporação do pessoal auxiliar e da equipe de saúde bucal na atenção básica.

Dessa forma, pode-se caracterizar o desenvolvimento das políticas de saúde bucal no país como um processo de continuidades e rupturas resultante das proposições oriundas do espaço da saúde bucal coletiva que se constituiu em disputa com a saúde pública tradicional, com a odontologia liberal e com os interesses de mercado. O aperfeiçoamento das políticas de saúde bucal e a incorporação de ações voltadas para a mudança do modelo assistencial se relacionaram com o desenvolvimento e a consolidação do espaço da saúde bucal coletiva, da saúde coletiva e do processo da Reforma Sanitária Brasileira que se constituíram em condições históricas de possibilidade para a formulação da Política Nacional de Saúde Bucal de 2004.

O estudo do financiamento representou o limite do presente estudo, na medida em que não avaliou os recursos executados nem utilizou cálculos econômicos relacionados com as necessidades da população, apontando para a possibilidade de estudos futuros sobre os termos "saúde oral" e "saúde bucal", assim como sobre o espaço odontológico.

A análise sóciohistórica desenvolvida auxilia na compreensão do complexo processo da formulação das políticas de saúde bucal, sendo possível apreender a lógica de continuidades e rupturas, as estruturas e a dinâmica do jogo social para interpretar melhor cenários futuros. 


\section{POSFÁCIO}

O dilema entre analisar um objeto bem delimitado, nos seus detalhes, e investigar as conexões mais amplas, perdendo, porém, algo do mergulho em profundidade, faz parte das decisões que o pesquisador tem que tomar, no cotidiano do seu ofício, como bem discutiu Bourdieu (1999 [1968]). Thais conseguiu um equilíbrio difícil entre essas duas abordagens ao optar pela análise do processo de formulação das políticas de Saúde Bucal em quatro décadas apoiada na sociologia de Bourdieu. Nessa perspectiva, o estudo do longo processo de construção social dos problemas de saúde bucal e das ações estatais voltadas para a sua resolução foi feito por meio da articulação entre a análise das trajetórias dos agentes envolvidos e as condições históricas de possibilidade.

A inserção dos dentistas nos diferentes campos (científico, político e burocrático) que compuseram os espaços sociais construídos nesse processo, foi objetivada por critérios ajustados para diferentes conjunturas históricas e consolidada de forma criativa em quadros, sociogramas, mapas e gráficos.

O estudo revelou como foi se constituindo, ao longo dos anos, um espaço social intercampos, responsável pela formulação de múltiplas estratégias voltadas para o seu enfrentamento. Também permitiu objetivar a arquitetura desse espaço nas diferentes conjunturas e sua influência em relação às tomadas de posição dos principais agentes envolvidos em relação ao problema da Saúde Bucal no Brasil. A oposição entre o polo público e o polo do mercado nos anos 1980 e a progressiva constituição de um subespaço crítico, formado por dentistas vinculados ao movimento sanitário, auxiliam na compreensão sobre a evolução das políticas nessas quatro décadas.

As transformações nesse espaço foram mostradas a partir da triangulação das informações obtidas de fontes diversas: entrevistas em profundidade, documentos ministeriais, boletins das entidades odontológicas, matérias divulgadas na 
imprensa. Essa rica documentação permitiu que a autora construísse seu objeto apoiando-se amplamente em evidências empíricas.

A análise da trajetória dos agentes e de suas tomadas de posição por referência às diversas estratégias voltadas para a resolução dos problemas da saúde bucal permitiram também identificar a contribuição específica de pesquisadores e docentes oriundos do campo universitário que opunham aos interesses do mercado o conhecimento técnico-científico.

A objetivação feita a partir das diversas fontes revelou que, a despeito do discurso dominante, priorizar a expressão Saúde Bucal ou Saúde Oral, na prática, o problema construído socialmente foi o da cárie, em relação ao qual se desenvolveram diversas disputas a respeito das estratégias mais efetivas para o seu controle.

Cabe um destaque à importância conferida pela autora aos movimentos específicos do espaço da Saúde Bucal Coletiva (SBC), a exemplo dos Encontros Nacionais de Administradores e Técnicos de Serviços Públicos (Enatespo), do Movimento Brasileiro de Renovação Odontológica (MBRO) e da Associação Brasileira de Saúde Bucal Coletiva (Abrasbuco). Além disso, não deixou de registrar o protagonismo dos dentistas no Movimento Sanitário Geral que se refletiu na construção dos problemas de saúde bucal de forma mais abrangente, relacionando-os aos determinantes sociais da saúde, o que culminou com a Política Brasil Sorridente.

Mostrando as relações dos eventos analisados com as conjunturas políticas e sanitárias, entre rupturas e continuidades, a autora vai pouco a pouco reconstituindo o complexo processo de formulação e implementação das políticas de saúde bucal, as disputas e consensos, as instituições e o encontro das trajetórias dos agentes. A análise sócio-histórica realizada cumpre assim seu papel de, para além da recuperação dos fatos, possibilitar a compreensão das opções feitas.

Salvador, abril de 2017

\section{Ligia Maria Vieira da Silva}




\section{REFERÊNCIAS}

ABO insiste na fluoração do sal para combater cárie. Jornal da ABO Nacional, São Paulo, p. 13, set./out. 1992.

AÇÃO COLETIVA. São Paulo: ABRASBUCO, v. 1, n. 1, 1998a.

AÇÃO COLETIVA. A São Paulo: ABRASBUCO, v. 1, n. 2. 1998b.

AÇÃO COLETIVA. São Paulo: ABRASBUCO, v. 1, n. 3, 1998c.

AÇÃO COLETIVA. São Paulo: ABRASBUCO, v. 1, n. 4, 1998d.

AÇÃO COLETIVA. São Paulo: ABRASBUCO, v. 2, n. 2, 1999a.

AÇÃO COLETIVA. São Paulo: ABRASBUCO, v. 2, n. 2, 1999 b.

AÇÃO COLETIVA. São Paulo: ABRASBUCO, v. 2, n. 3, 1999c.

AÇÃO COLETIVA. São Paulo: ABRASBUCO, v. 2, n. 4, 1999d.

ÁGUA com flúor previne cárie e todas as idades. O Estado de São Paulo, São Paulo, 1990.

ANDRADE, F. R. D. Análise das relações de poder na política nacional de saúde bucal: o dito e o visto. 2008. 170 f. Dissertação (Mestrado em Odontologia) Faculdade de Odontologia, Universidade Federal de Goiás, Goiania, 2008.

ANTUNES, J. L. F.; NARVAI, P. C. Políticas de saúde bucal no Brasil e seu impacto sobre as desigualdades em saúde. Revista de Saúde Pública, São Paulo, v. 44, p. 360-365, 2010. Disponível em: <http://www.scielo.br/scielo.php?script=sci_ arttext\&pid=S0034-89102010000200018\&nrm=iso>. Acesso em: 2 maio 2012.

ASSIS, L. N. de. Políticas de saúde bucal pós-constituinte (1999-2004). 2006. $421 \mathrm{f}$. Dissertação (Mestrado em Saúde Comunitária) - Instituto de Saúde Coletiva, Universidade Federal da Bahia, Salvador, 2006.

AUDIÊNCIA com presidente do Inamps. Jornal da Federação Interestadual dos Odontologistas, Brasília, DF, ano II, v. 3, p. 3, 1992. 
AZOGUI-LÉVY, S.; BOY-LEFÈVRE, M.-L. La Santé bucco-dentaire en France. Actualité Et Dossier en Santé Publique, Paris, v. 51, p. 4-8, juin 2005.

BARATA, R. B.; GOLDBAUM, M. Perfil dos pesquisadores com bolsa de produtividade em pesquisa do CNPq da área de saúde coletiva. Cadernos de Saúde Pública, Rio de Janeiro, v. 19, n. 6, p. 1863-1876, 2003. Disponível em: <http://www.scielo.br/scielo.php?script=sci_arttext\&pid=S0102311X2003000600031\&nrm=iso>. Acesso em: 16 maio 2013.

BARBOSA, S. Constituinte e a participação da odontologia. Saúde em Debate, Rio de Janeiro, n. 18, p. 2-3, mar./abr. 1986.

BARROS, S. G. D. A política nacional de luta contra a aids e o espaço aids no Brasil. 2013. 274 f Tese (Doutorado em Saúde Pública) - Instituto de Saúde Coletiva, Universidade Federal da Bahia, Salvador, 2013.

BARTOLE, M. D. C. S. Da boca cheia de dentes ao brasil sorridente: uma análise retórica da formulação da política nacional de saúde bucal. 2006. 129 f. Dissertação (Mestrado em Saúde Coletiva) - Instituto de Medicina Social, Universidade do Estado do Rio de Janeiro, Rio de Janeiro, 2006.

BITTAR, T. O. et al. O PES e a construção de uma Política de Saúde Bucal no Brasil. Revista da Faculdade de Odontologia, Passo Fundo, v. 14, n. 1, p. 71-76, 2009.

BLOCH, M. Apologia da história ou o ofício do historiador. Rio de Janeiro: Zahar, 2001.

BOLETIM INFORMATIVO. Rio de Janeiro: Rede CEDROS, n. 4, 1993.

BOLETIM INFORMATIVO. Rio de Janeiro: Rede CEDROS, n. 5, 1994.

BOLETIM INFORMATIVO. Rio de Janeiro: Rede CEDROS, n. 6, 1995.

BOLETIM DA FEDERAÇÃO INTERESTADUAL DOS ODONTOLOGISTAS. Brasília, DF: FIO, set./out. 1999.

BOLETIM DA FEDERAÇÃO INTERESTADUAL DOS ODONTOLOGISTAS. Brasília, DF: FIO, nov./dez. 2000.

BOLETIM DA FEDERAÇÃO INTERESTADUAL DOS ODONTOLOGISTAS. Brasília, DF: FIO, abr./maio 2004.

BOLETIM INFORMATIVO DO MOVIMENTO BRASILEIRO DE RENOVAÇÃO ODONTOLÓGICA. São Paulo: MBRO, 1985a.

BOLETIM INFORMATIVO DO MOVIMENTO BRASILEIRO DE RENOVAÇÃO ODONTOLÓGICA - MBRO. Brasília, DF: MBRO, 9 ago. $1985 \mathrm{~b}$.

BOLETIM INFORMATIVO DO MOVIMENTO BRASILEIRO DE RENOVAÇÃO ODONTOLÓGICA - MBRO. Pinheiros, SP: MBRO, n. 5, set. 1985c. 
BOLETIM INFORMATIVO MOVIMENTO BRASILEIRO DE RENOVAÇÃO ODONTOLÓGICA -MBRO. Belo Horizonte: MBRO, n. 12, 1987.

BOLETIM INFORMATIVO NACIONAL DO MOVIMENTO BRASILEIRO DE RENOVAÇÃO ODONTOLÓGICA - MBRO. Curitiba: MBRO, 1990.

BOLETIM DO MOVIMENTO BRASILEIRO DE RENOVAÇÃO ODONTOLÓGICA MBRO. [S.1.]: MBRO, n. 9, 1986.

BOURDIEU, P. Le capital social: notes provisoires. Actes de la recherche en sciences sociales, Paris, v. 31, p. 2-3, 1980.

BOURDIEU, P. Coisas ditas. São Paulo: Brasiliense, 2002.

BOURDIEU, P. A distinção: crítica social do julgamento. São Paulo; Edusp; Porto Alegre: Zouk, 2008.

BOURDIEU, P. A economia das trocas simbólicas. São Paulo: Perspectiva, 2011.

BOURDIEU, P. Meditações pascalianas. Rio de Janeiro: Bertrand Brasil, 2007.

BOURDIEU, P. O poder simbólico. Rio de Janeiro: Bertrand Brasil, 2001.

BOURDIEU, P. Questões de sociologia. Rio de Janeiro: Marco Zero, 1983.

BOURDIEU, P. Razões práticas: sobre a teoria da ação. Campinas: Papirus, 1996.

BOURDIEU, P. As regras da arte: genese e estrutura do campo literario. São Paulo: Companhia das letras, 1998.

BOURDIEU, P. Sur l'etat: cours au college de France 1989-1992. Paris: Raisons d'agir, 2012.

BOURDIEU, P. Os usos sociais da ciência: por uma sociologia do campo científico. São Paulo: Editora da UNESP, 2004.

BRASIL. Câmara dos Deputados. Projeto de Lei 2.852, de 1992. Estabelece a obrigatoriedade de fluoretação da água distribuida para consumo humano. Deputados: José Maria Eymael. Brasília, DF, 1992a.

BRASIL. Câmara dos Deputados. Projeto de Lei 1.331, de 1991. Objetiva tornar obrigatoria a fluoretação do cloreto de sódio $(\mathrm{NaCl})$ pelas industrias produtoras em todo o território nacional. Brasilia, DF, 1991a.

BRASIL. Congresso Nacional. Câmara dos Deputados. Projeto de Lei 1415/1968. Torna obrigatória em todo o território nacional a fluoretação da agua para abastecimento, quando existe estação de tratamento, e da outras providências. Autor: Baldacci Filho. Brasília, DF, 1968.

BRASIL. Congresso Nacional. Câmara dos Deputados. Projeto de Lei 2852/1992. Estabelecer a obrigatoriedade de fluoretação da água distribuída para consumo humano. Autor: José Maria Eymael. Brasília, DF, $1992 b$. 
BRASIL. Congresso Nacional. Câmara dos Deputados. Projeto de Lei 1133/1991. Tornar obrigatória a fluoretação do cloreto de sódio $(\mathrm{NaCl})$ pelas indústrias produtoras em todo o território nacional. Autor: Regina Gordilho. Brasília, DF, $1991 b$.

BRASIL. Decreto n 99.244, de 10 de maio de 1990. Dispõe sobre a reorganização e o funcionamento dos órgãos da Presidência da República e dos Ministérios e dá outras providências. Diário Oficial [da] República Federativa do Brasil, Brasília, DF, 11 maio 1990a.

BRASIL. Lei n 3.807, de 26 de agosto de 1960. Dispõe sobre a Lei Orgânica da Previdência Social. Diário Oficial [da] República Federativa do Brasil, Brasília, DF, 5 set. 1960.

BRASIL. Lei nº 6.050 de 24 de maio de 1974. Dispõe sobre a fluoretação da água em sistemas de abastecimento quando existir estação de tratamento. Diário Oficial [da] República Federativa do Brasil, Brasília, DF, 27 maio 1974.

BRASIL. Lei $\mathrm{n}^{\circ}$ 7.276, de 10 de dezembro de 1984. Estima a receita e fixa a despesa para o Exercício financeiro de 1985. Diário Oficial [da] República Federativa do Brasil. Brasília, DF, 17 dez. 1984.

BRASIL. Lei $n^{0} 7.420$, de 17 de dezembro de 1985. Estima a receita e fixa a despesa da União para o exercício financeiro de 1986. Diário Oficial [da] República Federativa do Brasil, Brasília, DF, 18 dez. 1985.

BRASIL. Lei $\mathrm{n}^{0}$ 7.544, de 3 de dezembro de 1986. Estima a receita e fixa a despesa da União para o exercício financeiro de 1987. Diário Oficial [da] República Federativa do Brasil, Brasília, DF, 4 dez. 1986a.

BRASIL. Lei $\mathrm{n}^{0}$ 7.632, de 3 de dezembro de 1987. Estima a Receita e fixa a Despesa da União para o exercício financeiro de 1988. Diário Oficial [da] República Federativa do Brasil, Brasília, DF, 4 dez. 1987a.

BRASIL. Lei n ${ }^{0} 7.715$, de 3 de janeiro de 1989. Estima a receita e fixa adespesa da União para o exercício financeiro de 1989. Diário Oficial [da] República Federativa do Brasil. Brasília, DF, 4 jan. 1989a.

BRASIL. Ministério da Previdência e Assistência Socia. Relatório Final da I Conferencia Nacional de Saúde BucalBrasília, DF, 1986 b.

BRASIL. Ministério da Saúde. Decretos de 21 de janeiro de 1992. Diário Oficial [da] República Federativa do Brasil. Brasília, DF, 21 jan. 1992c.

BRASIL. Ministério da Saúde. Diretirzes da Política Nacional de Saúde Bucal. Brasília, DF, 2004.

BRASIL. Ministério da Saúde. Diretrizes para a atuação dos Agentes Comunitários de Saúde na área de saúde Bucal. Brasília, DF, 1997. 
BRASIL. Ministério da Saúde. Estudo comparativo realizado na tabela de procedimentos odontológicos do SIA/SUS dos procedimentos coletivos, 2 semestre/ 94 e 1 semestre/95. Brasília, DF, 1995.

BRASIL. Ministério da Saúde. A inclusão da saúde bucal no Programa de Saúde da Família (Memória de cálculo). Brasília, DF, 2000a.

BRASIL. Ministério da Saúde. Levantamento epidemiológico em saúde bucal: Brasil, zona urbana. Brasília, DF, 1986c.

BRASIL. Ministério da Saúde. Memórias da saúde da família no Brasil. Brasília, DF, 2012.

BRASIL. Ministério da Saúde. A integração da saúde bucal no programa de Saúde da Família. Brasília, DF, 2000b.

BRASIL. Ministério da Saúde. Política Nacional de Saúde Bucal. Brasília, DF, 1988.

BRASIL. Ministério da Saúde. Portaria n 614/GM, de 13 de junho de 1989. Institui o Grupo de especialistas em Prevenção de Doenças Bucais para assessorar a Divisão Nacional de Saúde Bucal da Secretaria Nacional de Programas Especiais de Saúde. Diário Oficial [da] República Federativa do Brasil, Brasília, DF, 1989a.

BRASIL. Ministerio da Saúde. Política Nacional de Saúde Bucal. Brasília, DF, 1989b.

BRASIL. Ministerio da Saúde. Portaria nº 2, de 28 de fevereiro de 1991. Aprova as Normas Técnicas para o desenvolvimento do Prgrama Nacional do Controle da Carie, pelo método da fluoretação do Sal. Diário Oficial [da] República Federativa do Brasil, Brasília, DF, 11 mar. 1991c.

BRASIL. Ministerio da Saúde. Portaria no 43, de 4 de maio de 1993. Cancela o registro dos produtos Biosal e MOC. Diário Oficial [da] República Federativa do Brasil, Brasília, DF, 11 jun. 1993.

BRASIL. Ministerio da Saúde. Portaria nº 166, de 31 de dezembro de 1997. Descreve o elenco de procedimentod de Atencão Basica PAB e os procedimentos modificados e incorporados não identificados como PAB, da Tabela de Procedimentos do SAI/SUS. Fica os valores de procedimentos.Diário Oficial [da] República Federativa do Brasil, Brasília, DF, 22 jan. 1998.

BRASIL. Ministerio da Saúde. Portaria nº 184, de 9 de outubro de 1991. Estabelece o oferecimento, pelo Sistema Único de Saúde, de conjunto de procedimentos visando a promoção e prevenção em saúde bucal. Diário Oficial [da] República Federativa do Brasil, Brasília, DF, 10 out. 1991d.

BRASIL. Ministerio da Saúde. Portaria n 267, de 6 de março de 2001. Aprova As normas e diretrizes de inclusão da saúde bucal na estratégia do Programa de Saúde da Família (PSF). Diário Oficial [da] República Federativa do Brasil, Brasília, DF, 7 mar. 2001. 
BRASIL. Ministerio da Saúde. Portaria no 298, de 16 de junho de 1992. Aprova a tabela de procedimentos do SAI/SUS em vigência a partir de 1 de junho de 1993. Diário Oficial [da] República Federativa do Brasil, Brasília, DF, 19 jun. 1992d.

BRASIL. Ministerio da Saúde. Portaria no 419, de 24 de agosto de 1987. Aprova as alterações no Regimento Interno da Secretaria Nacional de Vigilância Sanitaria SNVS. Diário Oficial [da] República Federativa do Brasil, Brasília, DF, 1987b.

BRASIL. Ministerio da Saúde. Portaria n 560, de 1990. Dipensar ou exonerar a partir desta data. Diário Oficial [da] República Federativa do Brasil, Brasília, DF, 7 maio 1990b.

BRASIL. Ministerio da Saúde. Portaria no 851, de 4 de agosto de 1992. Torna insubsistentes a Portaria MS/GM n ${ }^{0} 1437$ de 14 de dezembro de 1990, e demais atos, no âmbito do Ministerio da Saúde, que regulamentava o Programa Nacional de Controle da Cárie pelo metodo de fluoretação do sal Diário Oficial [da] República Federativa do Brasil, Brasília, DF, 7 ago. 1992e.

BRASIL. Ministerio da Saúde. Portaria nº 1.437, de 14 de dezembro de 1990. Diário Oficial [da] República Federativa do Brasil, Brasília, DF, 17 dez. 1990d.

BRASIL. Ministerio da Saúde. Portaria nº 1.444, de 28 de dezembro de 2000. Estabelece incentivo financeiro para a reorganização da atenção à saúde bucal prestada nos municípios por meio do Programa de Saúde da Família. Diário Oficial [da] República Federativa do Brasil, Brasília, DF, 2000c.

BRASIL. Ministerio da Saúde. Proc. MS/Da nº 25000.011825/89. Diário Oficial [da] República Federativa do Brasil, Brasília, DF, 10 jan. 1990c.

BRASIL. Ministerio da Saúde. Proc MS/DA $n^{0}$ 25000.015743/89. Diário Oficial [da] República Federativa do Brasil, Brasília, DF, 1 fev. 1990d.

BRASIL. Ministério da Saúde. Programa Nacional de Prevenção da Carie Dental (Precad). Flúor x Cárie: um Brasil de dentes fortes. Brasília, DF, 1989c.

BRASIL. Ministério da Saúde. Relatório final da VIII Conferência Nacional de Saúde. Brasília, DF, 1986d.

BRASIL. Ministério da Previdência e Assistência Social. Programa de Reorientação da Assistência Odontológica. Brasília, 1983.

BRASIL. A reorganização da saúde bucal na atenção básica. Brasília, DF: Área Técnica de Saúde Bucal, 2000d.

BRASIL possui dentistas, mas poucos atuam. O Estado de São Paulo, São Paulo, 1981.

(O) Brasil tem 10 milhões de desdentados. Estado de São Paulo, São Paulo, p. 25, 1984. 
BUENDIA, O. C. Fluoeratação das águas: manual de orientação prática. Brasília, DF: American Med, 1996.

CALADO, G. S. A inserção da equipe de saúde bucal no Programa de Saúde da Família: principais avanços e desafios. 2002. 137 f. Dissertação (Mestrado em Saúde Pública) - Escola Nacional de Saúde Pública, Fundação Oswaldo Cruz, Rio de Janeiro, 2002.

CALDEIRA, M. Água com flúor previne cáries em todas as idades. Folha de São Paulo, São Paulo, p. C-8, 1990.

CARIE, o problema de 95\% dos brasileiros. O Estado de São Paulo, São Paulo, 1980.

CARTA de Belo Horizonte. Belo Horizonte, 2002. Documento de reunião por profissionais da área de saúde bucal, ligados aos setores de ensino e serviço 2002.

CARVALHO, L. A. C. et al. Procedimentos coletivos de saúde bucal: gênese, apogeu e ocaso. Saúde e Sociedade, São Paulo, v. 18, n. 3, p. 490-499, 2009. Disponível em: <http://www.scielo.br/scielo.php?script=sci_arttext\&pid=S0104$12902009000300013 \&$ nrm=iso>. Acesso em: 5 junho 2013.

CAVALCANTE, R. A. et al. Perfil dos pesquisadores da área de odontologia no Conselho Nacional de Desenvolvimento Científico e Tecnológico (CNPq). Revista Brasileira de Epidemiologia, São Paulo, v. 11, n. 1, p. 106113, mar. 2008. Disponível em: <http://www.scielo.br/scielo.php?script=sci_ arttext\&pid=S1415790X2008000100010\&lng=en\&nrm=iso`. Accesso em: 2 jun. 2016.

CHAVES, M. D. M. Fluoretação do sal: dados para elaboração de convênio INANFundação Universitária José Bonifácio (FUJB)/UFRJ. Rio de Janeiro, 1991. Memorando.

CHAVES, M. D. M. A hora e a vez da fluoretação do sal. Boletim Informativo - Rede CEDROS, Rio de Janeiro, ano 1, v. 2, 1992.

CHAVES, M. D. M. Odontologia social. São Paulo: Artes médicas, 1986.

CHAVES, M. D. M. Odontologia sanitária. São Paulo: Faculdade de Higiene e Saúde Pública, Universidade de São Paulo, 1960.

CIRURGIÕES-DENTISTAS dirigem-se ao Ministro Jair Soares, da Previdência. O Estado de São Paulo, São Paulo, 1981.

COHN, A. A reforma da previdência social: virando a página da história? São Paulo em Perspectiva, São Paulo, v. 9, n. 4, p. 59-64, 1995.

CONFERÊNCIA NACIONAL DE SAÚDE, 7., 1980, Brasilia, DF. Anais... Brasília, DF: Ministério da Saúde, 1980.

CONSELHO REGIONAL DE ODONTOLOGIA DO ESTADO DE SÃO PAULO - CRO/SP. Política Odontológica para um governo democrático. São Paulo, 1984. 
CRUZ, A. Flúor na água não! movimento contra a fluoretação das águas de abastecimento. 2007. Disponível em: <http://venenofluor.blogspot.com.br/2007/11/ fluoride-action-network.html>. Acesso em: 16 nov. 2015.

CURY, J. Flúor...Jô...Jaime Cury...1990-20?? Youtube. [S.1.], 13 ago. 2013.

Disponível em: <https://www.youtube.com/watch?v=o7QWCC9pk4s\&t=1s>. Acesso em: 12 dez. 2013.

DENTISTAS, agora o medo do orçamento. O Estado de São Paulo, São Paulo, 1981.

DENTISTAS estão mais confiantes. Estado de São Paulo. São Paulo, p. 14, 1985.

EIDELWEIN, C. Panorama, benfícios e controvérsias da fluoretação da água de abastecimento público no Brasil e no mundo: uma revisão de literatura. 2010. 62 f. Trabalho de Conclusão de Curso (Especialização em Saúde Pública - Faculdade de Medicina, Universidade Federal do Rio Grande do Sul, Porto Alegre, 2010.

ENCONTRO DE ADMINISTRADORES E TÉCNICOS DE SERVIÇOS PÚBLICOS ODONTOLÓGICOS - ENATESPO, 1984, Goiânia. Relatório Final... Goiânia: [s.n.], 1984.

ENCONTRO DE ADMINISTRADORES E TÉCNICOS DE SERVIÇOS PÚBLICOS ODONTOLÓGICOS - ENATESPO, 5., 1988, Recife. Relatório Final... Recife:

Secretaria de Estado da Saúde de São Paulo/Centro de Apoio ao Desenvolvimento das Ações Integrais de Saúde, 1988.

ENCONTRO DE ADMINISTRADORES E TÉCNICOS DE SERVIÇOS PÚBLICOS ODONTOLÓGICOS - ENATESPO, 7., 1990, Porto Alegre. Relatório Final... Porto Alegre:[s.n.], 1990.

ENCONTRO DE ADMINISTRADORES E TÉCNICOS DE SERVIÇOS PÚBLICOS ODONTOLÓGICOS - ENATESPO, 8., São Paulo, 1991. Relatório Final... São Paulo: [s.n.], 1991.

ENCONTRO DE ADMINISTRADORES E TÉCNISOC DE SERVIÇOS PÚBLICOS ODONTOLÓGICOS - ENATESPO, 14., 1998, Brasília, DF. Documento Final.. Brasília, DF: ABRASBUCO, 1998.

ENCONTRO DE ADMINISTRADORES E TÉCNISOC DE SERVIÇOS PÚBLICOS ODONTOLÓGICOS - ENATESPO, 15, 1999, Brasília, DF. Documento Final... Brasília, DF: ABRASBUCO, 1999.

ENCONTRO CIENTÍFICO DE ESTUDANTES DE ODONTOLOGIA, 2., 1981, Florianópolis: UFSC, 1981.

ESCOLAR, D. Autorização para registro de diplomas. Jornal Diário de Notícias, Brasília, DF, 1948. 
ESCOREL, S. História das Políticas de Saúde no Brasil. In: GIOVANELLA, L. et al. (Org.). Políticas e Sistema de Saúde no Brasil. Rio de Janeiro: Editora FIOCRUZ, 2008. cap. 11, p. 385-434.

ESCOREL, S. et al. O Programa de Saúde da Família e a construção de um novo modelo para a atenção básica no Brasil. Revista Panamericana de Salud Pública, v. 21, p. 164-176, 2007. Disponível em: <http://www.scielosp.org/scielo. php?script=sci_arttext $\&$ pid=S1020 $-49892007000200011 \&$ nrm=iso>. Acesso em: 16 nov. 2015.

ESTÁ faltando uma política nacional de Odontologia. Jornal do Brasil. Rio de Janeiro, 21 jul. 1982.

FALECIMENTOS - A diretoria e os conselheiros do CROSP, comovidos pela perda de tão brilhantes colegas, enviam às suas família as mais sinceras condolências. Jornal do Conselho Regional de Odontogia de São Paulo, São Paulo, n. 100, p. 11, set./ out. 2004.

FAQUIM, J. P. D. S.; CARNUT, LEONARDO. Pessoal auxiliar em odontologia: regulamentar da profissão de técnico em saúde bucal (1975-2008). Journal of Management and Primary Health Care, [S.1.], v. 3, n. 2, p. 202-207, 2012.

FIO presente no Conselho Nacional de Saúde. Jornal da Federação Interestadual dos Odontologistas, Brasília, ano 2, v. 3, p. 3, 1992a.

FIO solicita audiência com o Ministro da Saúde. Jornal da Federação Interestadual dos Odontologistas, Brasília, DF, ano 2, v. 3, p. 2, $1992 \mathrm{~b}$.

FOLHA DE SÃO PAULO. São Paulo: Folha da Manhã, 19 maio 1990. Caderno de Saúde.

FOME zero e boca cheia (de dentes)! proposta para a Saúde Bucal no Governo Lula dirigida à Equipe de Transição. São Paulo, 2002.

FRAZÃO, P.; NARVAI, P. C. Saúde bucal no Sistema Único de Saúde: 20 anos de lutas por uma política pública. Saúde em Debate, Rio de Janeiro, v. 33, n. 81, p. 6471, jan./abr. 2009.

FREIRE, A. M.; BARBOSA, S. D. N. Nota sobre a política de saúde da nova república. Brasília, DF, [s.n.], 1985.

FUNDAÇÃO SERVIÇOS DE SAÚDE PÚBLICA (Brasil) - FSESP. 30 anos de atividades em saúde pública. Brasília, DF, Ministério da Saúde, 1972.

FUNDAÇÃO SERVIÇOS DE SAÚDE PÚBLICA (Brasil) - FSESP. Atividades da FSESP. Brasília, DF: Ministério da Saúde, 1971.

FUNDAÇÃO SERVIÇOS DE SAÚDE PÚBLICA (Brasil) - FSESP. Normas técnicas de Odontologia Sanitária. Rio de Janeiro, 1963. 
GARCIA, D. D. V. A construção da politca nacional de saúde bucal: percorrendo os bastidores do processo de formulação. 2006. 104 f. Dissertação (Mestrado de em Saúde Coletiva) - Instituto de Medicina Social, Universidade do Estado do Rio de Janeiro, Rio de Janeiro, 2006.

GARRAFA, V. Democratização da odontologia. Saúde em Debate, Rio de Janeiro, V. 12, p. $52,1981$.

GUEDES, L. Prefeito de Cabo Frio quer manter o flúor no sal. O Estado de São Paulo, São Paulo, p. 1, 1992.

(O) GRITO de cada um. Boletim Informativo do Movimento Brasileiro de Renovação Odontológica, São Paulo, p. 8, 4 jun. 1985c.

GUERRA, A. Dentistas revelam a Tancredo ser grave a cárie dental no país. Jornal do Brasil, Brasília, DF, 1985.

HOBDELL, M. H. et al. Oral disease in Africa: a challenge to change oral health priorities. Oral Diseases, Hampshire, v. 3, n. 4, p. 216-222, 1997. Disponível em: <http://dx.doi.org/10.1111/j.1601-0825.1997.tb00044.X>. Acesso em: 16 nov. 2015.

IPEA. As políticas públicas e a desigualdade no Brasil: 120 anos após a abolição. Brasília, DF, 2008.

JORNAL DA ABOPREV. São Paulo: ABOPREV, ano 4, jul./set. 1993.

LAPA, F. D. S. Cirurgiões dentistas dirigem-se ao Ministro Jair Soares, da previdência. O Estado de São Paulo, São Paulo 1980.

LEMOS, A. M. F. Investimentos e cobertura em procedimentos coletivos em odontologia realizados no Brasil pelo Governo Federal na população de 5 a 14 anos na década de 90. 2002. 141 f. Dissertação (Mestrado em Saúde Pública) Faculdade de Saúde Pública, Universidade de São Paulo, São Paulo, 2002.

LENOIR, R. Objeto sociológico e problema social. In: CHAMPAGNE, P.; LENOIR, R. et al. (Ed.). Iniciação à prática sociológica. Rio de Janeiro: Vozes, 1996. cap. 2, p. 87-106.

LORENA SOBRINHO, J. E. de. Das bocas famintas às sorridentes: uma análise da política nacional de saúde bucal no Brasil. 2014. 227 f. Tese (Doutorado em Saúde Pública) - Centro de pesquisas Aggeu Magalhães, Fundação Oswaldo Cruz, Recife, 2014.

LUCENA, E. H. G. D.; PUCCA JÚNIOR, G. A.; SOUSA, M. F. D. A Política Nacional de Saúde Bucal no Brasil no contexto do Sistema Único de Saúde. Tempus: actas de saúde coletiva, Brasília, DF, v. 5, n. 3, p. 53-63, 2011.

MACHADO, C. V. Prioridades de saúde no Brasil nos anos 1990: três políticas, muitas lições. Revista Panamericana de Salud Pública, Washington, v. 20, n. 1, 
p. 44-49, 2006. Disponível em: <http://www.scielosp.org/scielo.php?script=sci arttext\&pid=S1020-49892006000700006\&nrm=iso>. Acesso em: 2 jun. 2012.

MACHADO, C. V.; BAPTISTA, T. W. D. F.; NOGUEIRA, C. D. O. Políticas de saúde no Brasil nos anos 2000: a agenda federal de prioridades. Cadernos de Saúde Pública, Rio de Janeiro, v. 27, p. 521-532, 2011. Disponível em: <http://www.scielo. br/scielo.php?script=sci_arttext\&pid=S0102-311X2011000300012\&nrm=iso>. Acesso em: 2 jun. 2012.

MACHADO, J. L. M.; CALDAS JR, A. L.; BORTONCELLO, N. M. F. Uma nova iniciativa na formação dos profissionais de saúde. Interface: comunicação, saúde, educação, Botucatu, v. 1, n. 1, p. 147-156, 1997. Disponível em: <http://www.scielo. br/scielo.php?script=sci_arttext\&pid=S1414-32831997000200011\&nrm=iso>. Acesso em: 5 set. 2014.

MANFREDINI, M. A. Saúde bucal no Brasil em 2008 e nos 20 anos de Sistema Único de Saúde. In: BRASIL. Ministério da Saúde. Saúde Brasil 2008: 20 anos de Sistema Único de Saúde no Brasil. Brasília, DF, 2009. p. 155-174.

MANFREDINI, M. A. Saúde Bucal no Programa de Saúde da Família no Brasil. In: DIAS, A. A. (Ed.). Saúde bucal coletiva: metodologia de trabalho e práticas. São Paulo: Santos, v. 1, 2006. cap. 3, p. 43-73.

MINISTÉRIO da Saúde quer sal com flúor no Norte e Noreste. O Estado de São Paulo. São Paulo, 1990.

NO DIA 26, você vai conhecer a realidade. Brasil, mostra sua boca. Panorama da saúde bucal do brasileiro. O Estado de São Paulo, São Paulo, 26 out. 1991.

MOYSÉS, S. J. Saúde bucal. In: GIOVANELLA, L. et al. (Org.). Políticas e sistema de saúde no Brasil. Rio de Janeiro: Editora FIOCRUZ, 2008. cap. 19, p. 705-734.

MOYSÉS, S. J. Políticas de saúde bucal no Brasil. In: MOYSÉS, S. J. (Ed.). Saúde coletiva: políticas, epidemiologia da saúde bucal e redes de atenção. São Paulo: Artes Médicas, 2014. , v.1, cap. 2, p. 128.

MOYSÉS, S. J.; GOES, P. S. A formulação de políticas públicas de saúde bucal. In: MOYSÉS, S. J.; GOES, P. S. (Ed.). Planejamento, gestão e avaliação em saúde bucal. São Paulo: Artes médicas, 2010. cap. 1, p. 15-32.

MOYSÉS, S. J. et al. Avanços e desafios à Política de Vigilância à Saúde Bucal no Brasil. Revista de Saúde Pública, São Paulo, v. 47, p. 161-167, 2013. Disponível em: <http://www.scielosp.org/scielo.php?script=sci_arttext\&pid=S003489102013000800161\&nrm=iso>. Acesso em: 2 jun. 2014.

NARVAI, P. C. Avanços e desafios da Política Nacional de Saúde Bucal no Brasil. Tempus: actas de saúde coletiva, Brasília, DF, v. 5, n. 3, p. 21-34, 2011. 
NARVAI, P. C. Mais dentistas? Jornal do Site Odonto, [S.1], 2000. Disponível em: $<$ http://www.jornaldosite.com.br/arquivo/anteriores/capel/capel6.htm>. Acesso em: 2 jun. 2014.

NARVAI, P. C. Odontologia e saúde bucal coletiva. São Paulo: Hucitec, 1994.

NARVAI, P. C. Saúde bucal coletiva: caminhos da odontologia sanitária à bucalidade. Revista de Saúde Pública, São Paulo, v. 40, p. 141-147, 2006. Número especial. Disponível em: <http://www.scielo.br/scielo.php?script=sci arttext\&pid=S0034-89102006000400019\&nrm=iso>. Acesso em: 2 jun. 2014. NARVAI, P. C. Sérgio Pereira. Saúde em Debate, Rio de Janeiro, v. 46, p. 28, mar. 1995.

NARVAI, P. C.; FRAZÃO, P. Políticas de saúde bucal no Brasil. In: MOYSÉS, S. T.; KRIGER, L.; KRIGER, L. (Org.). Saúde bucal das famílias: trabalhando com evidências. São Paulo: Artes Médicas, 2008a. p. 1-20.

NARVAI, P. C.; FRAZÃO, P. Saúde bucal no Brasil: muito além do céu da boca. Rio de Janeiro: Editora FIOCRUZ, 2008b.

NEDER, A. C. N.; MANFREDINI, M. A. Sobre a oportunidade de fluoretar o sal no Brasil: a modernidade do atraso. Saúde em Debate, Rio de Janeiro, v. 32, p. 73-76, jun. 1991.

NINOMURA, E. Programa de Saúde da Famíia será prioridade. Estado de São Paulo, São Paulo, p. A7, 2002.

NOVA diretoria na ABO Nacional. Jornal do Conselho Federal de Odontologia, Rio de Janeiro, 2004.

OLIVEIRA, A. G. R. D. C. Levantamento epidemiológico em saúde bucal - cárie dental: Brasil - 1996. Araçatuba: [s.n.], 1998.

ODONTOLOGIA pede prevenção da cárie. Jornal O Estado de São Paulo, São Paulo, p. 11, 1985.

ODONTOLOGIA social, propõem os dentistas. O Estado de São Paulo. São Paulo, p. 20.1981.

ORGANIZAÇÃO PAN-AMERICANA DA SAÚDE-OPAS. A política nacional de saúde Bucal do Brasil: registro de uma conquista histórica. Brasilia, DF, 2006. (Técnica Desenvolvimento de Sistemas e Serviços de Saúde, n. 11).

PAN AMERICAN HEALTH ORGANIZATION - PAHO. Promotins Oral Health. The use of salt fluoridation to prevent dental caries. Washington, 2005.

PAIM, J. S. Conjuntura e políticas de saúde: do PREV-Saúde ao Plano CONASP.

Saúde em Debate, Rio de Janeiro, n. 15/16, p. 8-15, 1984. 
PAIM, J. S. Políticas de saúde no Brasil. In: ROUQUAIROL, M. Z.; ALMEIDAFILHO, N. (Ed.). Epidemiolohia e saúde. Rio de Janeiro: Medsi, 2003. p. 587-603. PAIM, J. S. Reforma Sanitária Brasileira. Salvador: EDUFBA: Editora FIOCRUZ, 2008.

PAIM, J. S. O que é o SUS. Rio de Janeiro: Editora FIOCRUZ, 2009.

PINELL, P. Análise sociológica das políticas de saúde no Brasil. Rio de Janeiro: Editora FIOCRUZ, 2010.

PINTO, O. F. Mercúrio e Flúor - Rio Eco-odonto 1992. Youtube. [S.1.], 10 jul. 2013. Disponivel em: <https://www.youtube.com/watch?v=UYYMhZ3vG20>. Acesso em: 2 jun. 2014.

PINTO, V. G. Características do subsistema público federal de prestação dos serviços em odontologia. 1977. 188 f. Dissertação (Mestrado em Saúde Pública ) - Faculdade de Saúde Pública, Universidade do Estado de São Paulo, São Paulo, SP, 1977.

PINTO, V. G. A Odontologia Brasileira às vésperas do ano 2000: diagnóstico e caminhos a segui. São Paulo: Editora Santos, 1993.

PINTO, V. G. Programa Básico na área de saúde bucal a ser desenvolvido na administração do Deputado Dr. Alcenir Guerra no Ministério da Saúde. Brasília, DF, 1990.

PINTO, V. G. Serviços básicos de saúde: a experiência do PIASS. A Saúde no Brasil, Brasília, DF, v. 1, n. 2, p. 74-80, abr./jun. 1983.

PIRES, F. M. Políticas de saúde bucal: pingos e respingos. Porto Alegre: [s.n.], 2004.

PIRES, F. S. Organização tecnológica do trabalho em saúde bucal no SUS: uma arqueologia da política nacional de saúde bucal. 2013. $181 \mathrm{f}$. Tese (Doutorado em Ciências Odontológicas) - Faculdade de Odontologia, Universidade de São Paulo, São Paulo, 2013.

PIRES, F. S.; BOTAZZO, C. Organização tecnológica do trabalho em saúde bucal no SUS: uma arqueologia da política nacional de saúde bucal. Saúde e Sociedade, São Paulo, v. 24, n. 1, p. 273-284, 2015. Disponível em: <http://www.scielo.br/scielo. php?script=sci_arttext\&pid=S0104-12902015000100273\&nrm=iso>. Acesso em: 2 jun. 2015.

PRIMEIROS passos. Boletim Informativo do Movimento Brasileiro de Renovação Odontológica, São Paulo, n. 2, 1985.

PROGRAMA de Sal fluoretado deverá ter início em junho. Jornal da ABOPREV, São Paulo, ano 3, v. 6, p. 8 p. 1991.

PRONTO plano para Inamps mudar a sua assistência odontológica. O Estado de São Paulo, São Paulo, 1983. 
IBGE. Pesquisa Nacional de Amostras por Domicílios - PNAD. Rio de Janeiro, 1986. ODONTOLOGIA social, propoem os dentistas. O Estado de São Paulo. São Paulo, 1981.

PUCCA JÚNIOR, G. A. A tragédia da saúde bucal no Brasil. Folha de São Paulo, São Paulo, 21 set. 1992a.

PUCCA JÚNIOR, G. A saúde bucal no Brasil. Folha de São Paulo, São Paulo p. 1, 26 nov. $1992 b$.

PUCCA JÚNIOR, G. A. et al. Oral health policies in Brazil. Brazilian Oral Research, São Paulo, v. 23, p. 9-16, 2009. Disponível em: <http://www.scielo.br/scielo. php?script=sci_arttext\&pid=S1806-83242009000500003\&nrm=iso`. Acesso em: 2 jun. 2014.

REDE PARA COOPERAÇÃO EM ESTUDOS E DESENVOLVIMENTO DE RECURSOS ODONTOLÓGICOS PARA O SETOR SAÚDE (CEDROS). Rio de Janeiro, 8 ago. 1998. Disponível em: <http://www.ibiblio.org/cedros/>. Acesso em: 15 nov. 2015.

RENDEIRO, M. M. P. O Ciclo da Política de Saúde Bucal no Sistema de Saúde Brasileiro: atores, idéias e Instituições. 2011. 188 f. Dissertação (Mestrado em Saúde Pública) - Escola Nacional de Saúde Pública, Fundação Oswaldo Cruz, Rio de Janeiro, 2011.

RIO DE JANEIRO, pioneiro com flúor no sal de cozinha. Jornal da ABORJ, Rio de Janeiro, p. 18, jan./fev. 1993.

SALDANHA, I. F. et al. Cabo Frio do Gecahy ao sal com Flúor. Cabo Frio, 1992.

SANTOS, S. M. C. et al. Perfil dos pesquisadores da Saúde Coletiva no Conselho Nacional de Desenvolvimento Científico e Tecnológico. Physis: Revista de Saúde Coletiva, Rio de Janeiro, v. 19, n. 3, p. 761-775, 2009. Disponível em: <http://www.scielo.br/scielo.php?script=sci_arttext\&pid=S0103$73312009000300012 \&$ nrm=iso>. Acesso em: 15 set. 2014.

SAÚDE pública, gratuita e de qualidade. Jornal do Conselho Federal de Odontologia, Rio de Janeiro, p. 8, set. 2000.

SCHWARZ, E. Access to oral health care - an Australian perspective. Community Dentistry and Oral Epidemiology, Copenhagen, v. 34, n. 3, p. 225-231, 2006. Disponível em: <http://dx.doi.org/10.1111/j.1600-0528.2006.00301.x>. Acesso em: 15 set. 2014.

SERAPHIM, A. M. Saúde reivindica mais 13,6 trilhões. O Estado de São Paulo, São Paulo, p. 26, 1985.

SERRA, C. G. A saúde bucal como política de saúde: análise de três experiências recentes: Niterói, Campinas e Curitiba. 1998. 132 f. Dissertação (Mestrado) - 
Instituto de Medicina Social, Universidade do Estado do Rio de janeiro, Rio de Janeiro, 1998.

SHAH, N. Oral health care system for elderly in India. Geriatrics \& Gerontology International, [Tokyo], v. 4, n. s1, p. S162-S164, 2004. Disponível em: <http://dx.doi. org/10.1111/j.1447-0594.2004.00187.x>. Acesso em: 15 set. 2014.

SOARES, C. L. M. Constructing public oral health policies in Brazil: issues for reflection. Brazilian Oral Research, São Paulo, v. 26, p. 94-102, 2012. Disponível em: <http://www.scielo.br/scielo.php?script=sci_arttext\&pid=S180683242012000700014\&nrm=iso>. Acesso em: 15 set. 2014.

SOARES, C. L. M. A constituição da Saúde Bucal Coletiva no Brasil. 2014. 179 f. (Doutorado em Saúde Pública) - Instituto de Saúde Coletiva, Universidade Federal da Bahia, Savador, 2014.

SOUZA, D. S. A saúde bucal no Sistema Único de Saúde. Saúde em Debate, Rio de Janeiro, v. 6, n. p. 4-9, out. 1991.

SOUZA, J. C. D. A gênese do Programa de Incentivo Fiscal à alimentação do trabalhador (PIFAT/PAT). 2013. 278 f. Tese (Doutorado em Saúde Coletiva) Instituto de Saúde Coletiva, Universidade Federal da Bahia, Salvador, 2013. TEIXEIRA, C. F.; PAIM, J. S. A política de saúde no governo Lula e a dialética do menos pior. Saúde em Debate, Rio de Janeiro, v. 29, n. 71, p. 268-283, 2005.

TRINTA Milhões nunca foram ao dentista. Jornal do Brasil, Rio de Janeiro, p. 7. 2000.

UCHOA, H. W. Resposta às suas perguntas sobre fluoretação do sal de cozinha. Rio de Janeiro, 2015.

USO de flúor no sal de cozinha gera polêmica. O Estado de São Paulo, São Paulo, 1991a.

VEIGA, F. P. D. Senhor Ministro da Saúde Doutor Jamil Haddad. Abaixo assinado em favor da fluoretação do Sal no Brasil, em crítica à postura do Ministro de Cancelamento do Programa. 1993.

VIANNA, M. I. P. Estado e atenção odontológica no Brasil: um estudo sobre as Políticas de saúde bucal na conjuntura pós-74. 1988. 211 f. Dissertação (Mestrado em Saúde Comunitária.) - Instituto de Saúde Coletiva, Universidade Federal da Bahia, Salvador, 1988.

VIANNA, S. M.; PINTO, V. G. Programa de Fluoretação da água de abastecimento público. Brasília, DF: IPEA, 1983.

VIANNA, S. M.; PIOLA, S. F.; PINTO, V. G. Programa de Saúde do Escolar. Brasília, DF: IPEA, 1983. 
VIEIRA-DA-SILVA, L. M. O espaço da saúde coletiva. Salvador, 2010. Relatório de pesquisa.

VIEIRA-DA-SILVA, L. M. et al. Análise sócio-histórica das políticas de saúde. Algumas questões metodológicas da abordagem bourdieusiana. In: TEIXEIRA, C. F. (Org.). Observatório de análise política em saúde. 1. ed. Salvador: EDUFBA, 2016. v. 1, p. 15-40.

VIEIRA-DA-SILVA, L. M.; PINELL, P. The genesis of collective health in Brazil. Sociology of Health \& Illness, Oxford, v. 36, n. 3, p. 432-446, 2014. Disponível em: <http://dx.doi.org/10.1111/1467-9566.12069>. Acesso em: 13 nov. 2015.

WEBER, M. A política como vocação. Brasília, DF: Editora da Universidade de Brasília, 1982.

WERNECK, M. A. F. A saúde bucal no SUS: uma perspectiva de mudança. 1994. 194 f. Tese (Doutorado em odontologia Social) - Faculdade de Odontologia Universidade Federal Fluminense, Rio de Janeiro, 1994.

WEYNE, S. D. C. A construção do paradigma de promoção de saúde - um desafio para as novas gerações. In: MÉDICAS, E. A. (Ed.). Promoção de saúde bucal. São Paulo: ABOPREV, 1999. v. 2, cap. 1, p. 2-26.

WRIGHT, F. A. C.; LIST, P. F. Reforming the mission of public dental services. Community dentistry and oral epidemiology, Copenhagen, v. 40, p. 102-109, 2012. Disponível em: <http://dx.doi.org/10.1111/j.1600-0528.2012.00728.x>. Acesso em: 13 nov. 2015.

ZANETTI, C. H. G. As marcas de mal-estar social no Sistema Nacional de Saúde: o caso das políticas de saúde bucal, no Brasil dos anos 80.1993. 294 f. (Mestrado em Saúde Pública) - Escola Nacional de Saúde Pública, Fundação Oswaldo Cruz, Rio de Janeiro, 1993.

ZANETTI, C. H. G. Saúde Bucal: um desafio à democratização do setor. Saúde em Debate, Rio de Janeiro, v. 45, p. 17-22, 1994. 


\section{Colofão}

Formato: $19,5 \times 27 \mathrm{~cm}$

Tipologia: Tiempos Text / Montserrat

Papel: Alcalino $75 \mathrm{~g} / \mathrm{m}^{2}$ (miolo)

Cartão Supremo $300 \mathrm{~g} / \mathrm{m}^{2}$ (capa)

Impressão: EDUFBA

Capa e acabamento: Cartograf

Tiragem: 400 